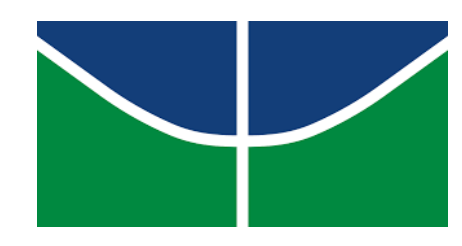

UNIVERSIDADE DE BRASÍLIA

FACULDADE DE DIREITO

PROGRAMA DE PÓS-GRADUAÇÃO EM DIREITO

SOBERANIA POLICIAL NO RECIFE DO INÍCIO DO SÉCULO XX

MANUELA ABATH VALENÇA

BRASÍLIA

2018

Manuela Abath Valença 


\section{SOBERANIA POLICIAL NO RECIFE DO INÍCIO DO SÉCULO XX}

Tese de Doutorado apresentada ao Programa de Pós-Graduação em Direito da Universidade de Brasília, para a obtenção do título de Doutora em Direito, Estado e Constituição. Linha de pesquisa: Sociedade, Conflito e Movimentos Sociais.

Orientadora: Profa. Dra. Ela Wiecko Volkmer de Castilho.

\section{BRASÍLIA}


Após sessão pública de defesa desta Tese de Doutorado, a candidata foi considerada aprova pela Banca Examinadora.

Profa. Dra. Ela Wiecko Volkmer de Castilho

Orientadora

Profa. Dra. Marília Montenegro Pessoa de Mello Membro UFPE/UNICAP

Profa. Dra. Vera Malaguti Batista

Membro UERJ

Profa. Dra. Camila Cardoso de Mello Prando

Membro UnB

Brasília, 1 de fevereiro de 2018 
A mainha e a painho. 


\section{AGRADECIMENTOS}

Pelejei muito para fazer esses agradecimentos. Não porque não tenha a quem ou ao que agradecer. Muito pelo contrário, nesses últimos quatro anos de tese e de vida, eu me tornei ainda mais grata e ciente da importância fundamental das pessoas ao meu redor e daquelas que, mesmo não convivendo comigo, são generosas e atenciosas. Definitivamente, eu não teria conseguido percorrer e concluir esse caminho sozinha e, portanto, agradeço imensamente a todos e a todas que o tornaram possível.

Agradeço à professora Ela por ter me acolhido como orientanda. Foi uma alegria enorme poder conviver e aprender com uma das mulheres mais admiráveis do campo jurídico, que é só exemplo de coragem, de dedicação e de coerência.

Já no primeiro ano de doutorado eu cruzei com pessoas incríveis, as quais admiro muito e com as quais aprendo imensamente. Como pode tanta gente boa junta? Felipe Freitas, Pedro Brandão, Camilla Magalhães, Carolina Ferreira, Paula Ballesteros, Roberta Amanajás, Vladimir Soares, Fernando Antunes... Que sorte poder conviver com mentes brilhantes e sagazes; com almas inquietas e militantes e com amigos e amigas atenciosos... Todos vocês fizeram de meu doutorado na UnB uma das experiências mais enriquecedoras de minha vida. Obrigada!

De quebra, em Brasília ainda moravam recifenses que eram portos seguros para mim. Agradeço a Eduarda Paiva pela amizade, pelas conversas, pelos conselhos, pelas caronas, pelo quarto em sua casa, cedido tantas vezes desde a seleção, e pelo exemplo de disciplina. Você é só inspiração, Dudinha. Agradeço de novo a Pedro Brandão, porque, além de colega de pósgraduação, era amigo desde o mestrado na UFPE e é um exemplo de academia militante. Obrigada por sonhar em voz alta, Pedrito! Agradeço, ainda, a Natália Leitão, Thais Moraes, Maria Eduarda Borba, Marcelo Prudente, Thiago Cadeira, Carlinha. Vocês fizeram de Brasília um lar.

Agradeço a todo o Grupo Asa Branca de Criminologia pela existência e persistência nesse terreno árido que são as pesquisas sobre a justiça penal. Nomear cada um de vocês seria impossível, porque são muitos. Mas nomeio a pessoa que coordena essa ciranda, como ela gosta de dizer. Obrigada, Marília Montenegro, por encantar essa dança, ensinando que esse caminho só vale a pena mesmo se formos de mãos dadas. Você não apenas anuncia, mas pratica isso todos os dias. Agradeço, ainda, às amigas e professoras com quem divido o dia a dia da docência, da pesquisa e das eternas inquietações, Fernanda Rosenblatt, Carolina Salazar e Helena Castro. Vocês são fundamentais na minha formação e existência. Agradeço também a Malu e a Virgínia Leal pela parceria.

Agradeço a Luciano Oliveira, professor e orientador de quase todo o Asa Branca, o maior exemplo que poderíamos ter de uma docência e academia sérias, dedicadas, honestas; alguém se recusa ao produtivismo fordista imposto pelos órgãos que gerem a pesquisa no Brasil. De quebra, é um amigo, uma presença que me deu muita força nesses últimos anos. 
Agradeço a Roberto Efrem e a Jacqueline Florêncio pela amizade, pelo exemplo de militância, e também a todo o NAJUP, por terem estado nas marchas contra o impeachment e todos os retrocessos que estamos vivendo, quando eu precisei estar em casa fazendo a tese. Minha ausência não fazia diferença, mas a presença de pessoas como vocês, sim. Já murcharam a nossa festa, pá, mas, certamente "esqueceram uma semente em algum canto de jardim".

Agradeço aos meus alunos e minhas alunas, por me fazerem me sentir no lugar e na profissão certa todos os dias. Nomeá-los também não seria possível. Mas, agradeço, por todos, a Marcela Borba, Júlio Paschoal e Fernanda Lima pelo aprendizado, pela paciência, pelo exemplo, pela energia que me deram quando parecia não mais existir, pelas risadas descompromissadas, pela escuta, por me entenderem só pelo meu olhar. A Nandinha eu ainda agradeço pela leitura atenta do texto dessa tese e pelas correções.

Agradeço também aos funcionários do Arquivo Público Estadual Jordão Emereciano. Eles fazem muito com muito pouco, quando deveriam contar com melhor estrutura e recursos, afinal, guardam a memória de nossa sociedade, sem a qual não saberemos como caminhar. Não me impressiona o sucateamento, mas me entristece. De qualquer forma, sem eles, especialmente Hildo e Emerson, eu não teria conseguido acessar os documentos com os quais trabalhei.

Agradeço aos amigos e amigas que, mesmo não dividindo, hoje, as aulas e o trabalho comigo, dão graça a minha vida: Renata Alencar, Mariana Raposo, Sofia C. Rego, Larissa Avelar, Maíra Moraes, Serginho, Luís, Firmino, Camila Vidal, Mariana Guedes e todas as fdrianas membros do Inimputáveis F.C. Agradeço, também, a Mazira, minha psicóloga maravilhosa.

Agradeço a minha amada família, às vezes um mar calmo, às vezes um furacão, mas sempre o lugar onde quero estar. Painho e mainha, Duda, Antonio, Bruno, Lo, Bruninho, Léo, Lu, Gui, Tio Murilo, Tia Flávia, Tia Tina, Laís e Marcela, Vovó, que não está mais aqui, mas que nos consagrou tudo o que somos, enfim, todos e todas que não consigo nomear porque vovó teve muitos filhos, obrigada!

Agradeço, finalmente, ao novo integrante disso que chamo família, Oussama Naouar. Te agradeço, lindo, por esse último ano e todas as dificuldades que ele envolveu. Pelo incentivo, por me dizer todos os dias "tu dois finir ta thèse". Nosso encontro, repentino, inesperado, não anotado e não agendado, do jeito que você prefere e que me deixa meio medrosa, está sendo como um banho de mar quentinho, sob o sol ou sob a lua. Merci, mon coeur. 


\section{RESUMO}

Este trabalho objetivou compreender as práticas policiais no Recife do início do século XX, percorrendo suas dinâmicas e condições. Para o estudo, foi realizada uma análise qualitativa de fontes oficiais policiais, colhidas no Arquivo Público Estadual Jordão Emerenciano, da legislação penal e processual penal do período, da doutrina processual penal e dos anais da Conferência Judiciária-Policial de 1917. Os dados registram policiais que atuavam como verdadeiros "donos da rua" ou como uma justiça de primeira instância, fenômeno aqui conceituado como soberania policial. A soberania policial se expressa quando policiais, dos mais diversos estratos e corporações, imbuem-se de executar suas atividades sem mediação da lei ou de outra instância estatal, recorrendo frequentemente à informalidade. Essa atuação se dá em dois níveis: resolução de conflitos criminais ou não, reportados pela população às forças policiais civis ou militares e repressão à desordem. Neste último caso, quantitativamente mais relevante que o primeiro, a polícia persegue um conjunto de pessoas que, no início do século passado, compunham a imagem do perigo social: vagabundos, mendigos, ébrios, menores, prostitutas e operários, todos criminalizados pelos tipos contravencionais contidos no Código Penal de 1890. Essa perseguição e repressão se davam, quase sempre, através de prisões sem processo, detenções para averiguação, varejamentos em domicílio sem ordem da autoridade, vigilância e mapeamento dos movimentos operários, controle da imprensa, regulamentação do uso do espaço público e também em negociações, acordos, corrupção e favorecimentos. Era um misto de patrimonialismo e violência, típico das relações sociais brasileiras. Procurou-se também demonstrar como o campo jurídico foi conivente com esse fenômeno, ao silenciar sobre ele ou a dar interpretação ampla ao poder de polícia. Utilizou-se, enfim, como marco teórico a criminologia crítica e os estudos sobre racismo e sistema penal.

Palavras-chave: soberania policial; desordem social; contraventores; racismo; início do século $\mathrm{XX}$ 


\begin{abstract}
This thesis aimed to understand police practices in Recife city on early twentieth century trying to understand its dynamics and conditions. To do so, official data from police sources were colected on Pernambuco State's public archive - Arquivo Público Estadual Jordão Emerenciano - and were qualitatively analysed. The criminal law, criminal procedure and others relevants laws and doctrine were investigated, including, also, the annals of the Judiciary and Police Conference of 1917. Data suggested that police officers acted like "street owners" or like a first instance Court, phenomenon here regarded as police sovereignty. Police sovereignty is when police officers, from distinct status and Corporation, use to execute their activities not taking into account the law or other official organization, acting informally. These king of activities are expressed in two scales: resolutions of criminal or non-criminal conflicts, reported to the police by the community and repression and persecution of public disorders. In this last case, quantitatively more relevant than the first, the police officers persecute a group of people seen as dangerous at that moment: vagrants, beggars, idles, drunkards, prostitutes and organized workers. The Brazilian criminal law, Criminal Code of 1890, considered these behaviors as minor offenses - contraventions, and so, these people could effectively be penalized. This persecution was almost always carried out through illegal attitudes as: prisons without trial and without judicial order, detentions to inquiry without judicial authorization, houses searched without a warrant, monitoring and mapping of labor organizations, control of the press, ruling the use of public space, informal negotiations with citizens and corruption. Patrimonialism and violence, the typical features of social relations in Brazil were the face of police officers actions. We aimed, also, to demonstrate how de judicial field was conivent to these phenomenon by silencing about it or constructing broad interpretations of police power. Finally, critical criminology and studies on racism and the penal system were used as a theoretical framework.
\end{abstract}

Key words: police sovereignty; social disorder; contravention; racism, begginig of XX century. 


\section{RESUMÉE}

Ce travail se donne pour objectif de comprendre les pratiques policières à Recife au début du XXe siècle, à travers ses dynamiques et conditions. À cette fin, cette recherche repose sur une analyse qualitative des fonds officiels de la Police, recueillis aux Archives Publiques de l'État "Jordão Emerenciano", mais aussi sur la législation pénale et processuelle de cette époque, la doctrine de la procédure pénale et les annales de la conférence Judicio-policière de 1917. Les données donnent à voir des policiers qui agissent en vrais "maîtres de la rue" ou comme une justice de première instance, phénomène conceptualisé dans cette thèse comme souveraineté policière. La souveraineté policière s'exprime lorsque des policiers, de diverses origines et corporations, s'autorisent à exécuter leurs activités sans médiation de la loi ou d'une autre instance étatique, préférant fréquemment le registre informel. Cette situation se reflète à deux niveaux: résolution de conflits criminels ou pas rapportés par la population aux forces de Police Civile ou Militaire et répression de l'atteinte à l'ordre public. Dans ce dernier cas, quantitativement plus important que le premier, la police cible un ensemble de personnes qui, au début du siècle passé, composent l'image du danger social: vagabonds, mendiants, personnes en état d'ébriété, mineurs, prostituées et ouvriers, tous criminalisés par les types de contraventions contenus dans le Code Pénal de 1890. Cette persécution et cette répression se matérialisaient, presque toujours, à travers des emprisonnements sans procès, des gardes-àvue arbitraires, des perquisitions à domicile sans ordre des autorités, des surveillances et un renseignement autour des mouvements ouvriers, un contrôle de la presse, la réglementation de l'usage de l'espace public et des négociations, des accords, de la corruption et du favoritisme. Il s'agissait d'un mélange de patrimonialisme et de violence, caractéristiques des relations sociales brésiliennes. Ce travail tente de démontrer comment le champ juridique entretenait des connivences avec ce phénomène: soit en fermant les yeux, soit en donnant une interprétation ample au pouvoir de la police. Le cadre théorique est celui de la criminologie critique et des études sur le racisme et le système pénal.

Mots-clés: souveraineté policière, désordre social, contravenants; racisme, début du XXeme siècle 


\section{SUMÁRIO}

INTRODUÇÃ

1 CAMINHOS E PERCALÇOS DA PESQUISA EM BUSCA DA COMPREENSÃO DO CONTROLE POLICIAL NO INÍCIO DO SÉCULO XX................................................. 20

1.1 TRAJETÓRIAS EM CAMPO ATÉ A DELIMITAÇÃO DO OBJETO.......................20

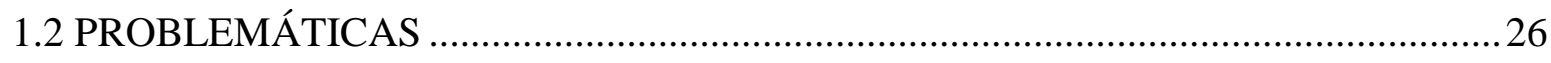

1.3 ENSAIANDO O CONCEITO DE SOBERANIA POLICIAL ...................................... 34

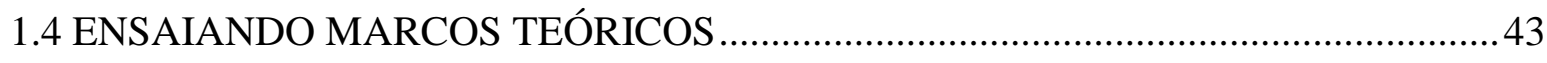

1.4.1 A criminologia crítica latinoamericana........................................................................43

1.4.2 A perspectiva das teorias raciais aplicadas ao sistema punitivo .........................48

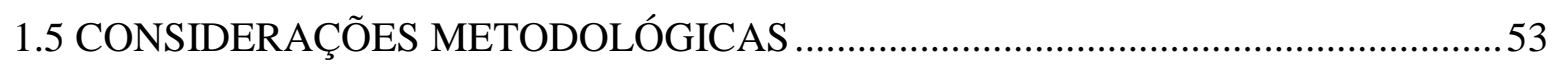

1.5.1 O espaço e o tempo: o centro do Recife entre 1915 e 1930 ................................53

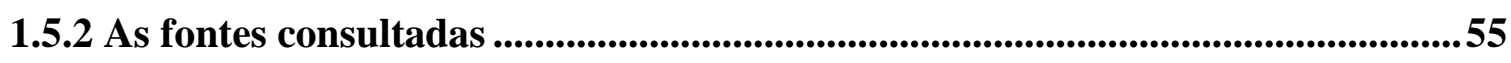

1.5.3 Os limites das fontes históricas ..............................................................................59

2 AS POLÍCIAS NO INÍCIO DA REPÚBLICA ENTRE O SONHO CIVILIZACIONAL E AS PRÁTICAS INFORMAIS NO COTIDIANO DE FAMÍLIAS

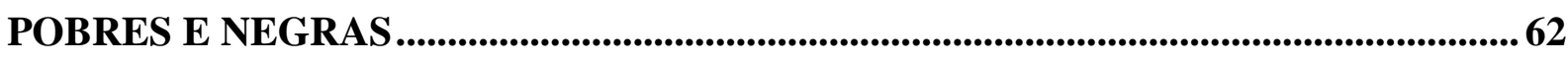

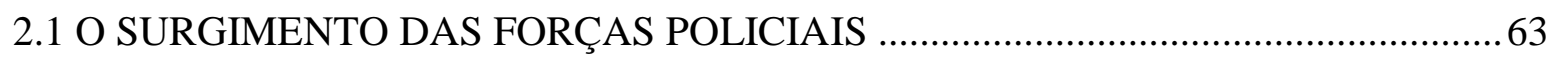

2.2 UMA POLÍCIA AMBIVALENTE: DE ESPAÇO DE RESOLUÇÃO DE CONFLITOS

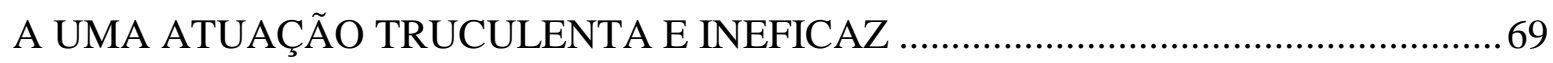

2.3 DO “CAPOEIRA DE FARDA" A SHERLOCK HOLMES: UMA POLÍCIA QUE SE

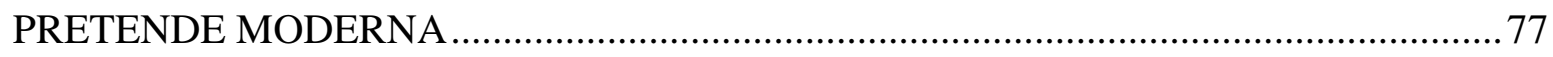

3 SOBERANIA POLICIAL E O CAMPO JURÍDICO .............................................. 87

3.1 SILÊNCIOS, LIBERALISMO À BRASILEIRA E SOBERANIA POLICIAL ............90

3.2 A PROGRAMAÇÃO CRIMINALIZANTE DO SÉCULO XIX E SEUS REFLEXOS

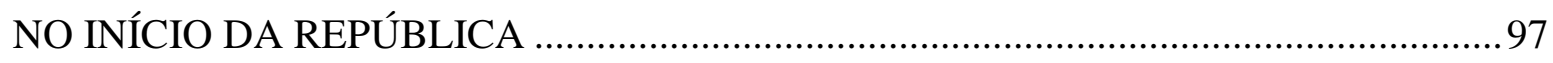

3.3 A SOBERANIA POLICIAL E A LEGISLAÇÃO PROCESSUAL PENAL ................ 106

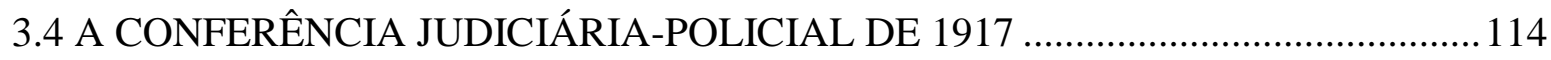


4 OS MUCAMBOS E A RUA: UNIDADES ESPACIAIS DA SOBERANIA

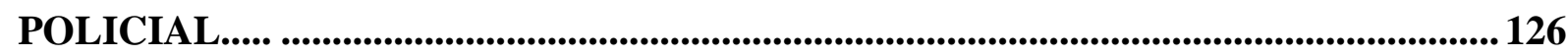

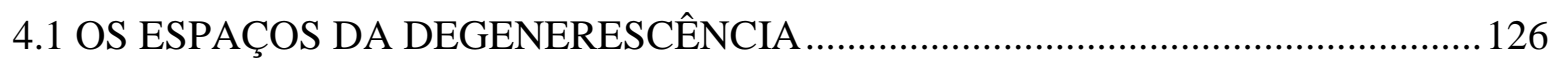

4.2 AS PRIORIDADES POLICIAIS: AFINAL, COM O QUE A POLÍCIA SE

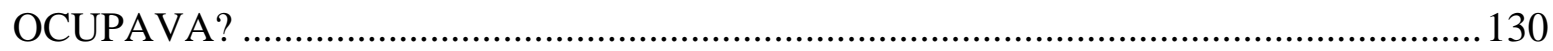

4.3 A POLÍCIA ORDEIRA: VADIOS, DESORDEIROS, ÉBRIOS E MENORES .........142

4.4 A POLÍCIA MORAL: AS MULHERES E O CONTROLE PENAL FORMAL .........155

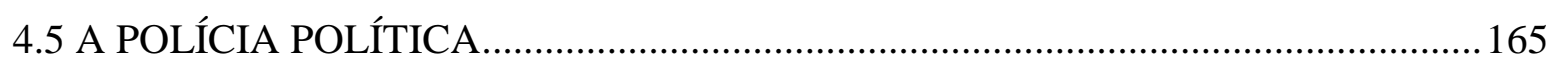

5 SOBERANIA POLICIAL E A UTOPIA DISCIPLINAR ......................................175

5.1 O IDEAL CORRECIONALISTA E A CRIMINOLOGIA POSITIVISTA .................179

5.2 A DISCIPLINA DOS CORPOS SEM ALMA .................................................... 188

5.3 A SOBERANIA POLICIAL CONTRA A UTOPIA DISCIPLINAR OU EU “PROCEDO COMO QUISER NAS HORAS DE SERVIÇO”.........................................196

5.3.1 Negociações e acordos ....................................................................................197

5.3.2 Conflitos entre policiais e militares....................................................................................201

5.3.3 Prisões correcionais, prisões para averiguação e varejamentos: os métodos de

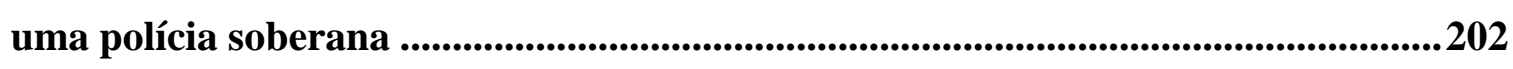

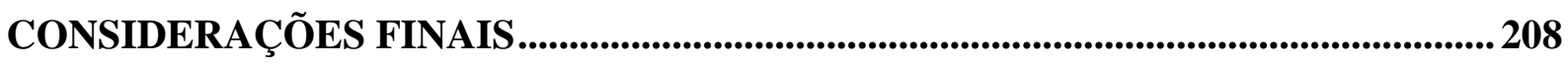

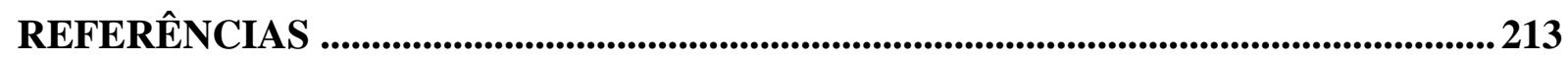

ANEXOS 


\section{INTRODUÇÃO}

Em 2006, eu ainda era graduanda do curso de direito da Faculdade de Direito do Recife (FDR) e integrante do Núcleo de Assessoria Jurídica Popular- Direito nas Ruas (NAJUP), quando fui, junto a meus amigos, comunicada por um colega do curso de jornalismo que P., um jovem de 18 anos, negro, articulador político e cultural e morador do Coque, bairro pobre da cidade do Recife, havia sido preso por desacato. Na época, a FDR era, em geral, um espaço de pessoas brancas, egressas de escolas particulares e moradoras de bairros ricos da cidade. Toda a narrativa apresentada pelo colega de jornalismo naquela ligação de celular foi, portanto, um choque. Para mim e para meus amigos.

P. estava em casa, por volta da $19 \mathrm{~h}$, quando três policiais teriam batido na porta e exigido entrar. P. disse que não era possível ingressar na sua casa naquele horário e, muito menos, sem mandado judicial. P. foi detido, colocado em um camburão, agredido, levado a uma delegacia de polícia - à época, a conhecida por ser "a pior", onde tudo acontecia - e, contra ele, lavrado um Termo Circunstanciado de Ocorrência por "Desacatar funcionário público no exercício da função ou em razão dela".

Cerca de um ano depois, acompanhei P. na audiência de transação penal. Por que não arquivar aquilo? O que ele havia feito? E os maus tratos que ele havia sofrido? Muitas perguntas eu trazia comigo e P., por certo, muitas consigo. Ao chegar ao rol do fórum Tomás de Aquino, onde ficam alguns dos juizados especiais criminais, P. viu seu nome na ata de audiências e me perguntou: “eu sou autor do fato?”. Esboçou, em seguida, um leve sorriso de ironia. Eu disse que aquela era a linguagem da lei 9.099 de 1995, que trocava réu por autor do fato. A explicação não poderia ser pior. A audiência foi adiada. Depois, quando remarcada, o crime estava prescrito.

Em 2016, P. fez uma palestra na FDR e falou a uma turma de processo penal: “constituição é uma coisa que vocês conhecem aqui. No Coque, não tem constituição". Essa fala não era apenas dele, era a dos já então muitos alunos e alunas daquela Faculdade. Era a de Higor Alexandre Araújo, orientando da professora Marília Montenegro, que fez um trabalho de conclusão de curso sobre flagrante forjado porque

O flagrante forjado ocupa poucos espaços nos manuais de direito penal e processual penal que existem no mercado; limitam-se a dizer o óbvio: tratase de uma ilegalidade, que gera nulidade da prisão e responsabilização dos agentes. Mas a realidade mostra que agentes policiais são capazes de forjar flagrantes para prender certas pessoas - e a forja com drogas é a forma mais fácil. Eu, morador da Comunidade (ou Favela, como afetivamente 
chamamos) dos Coelhos, vivo essa realidade, e a confirmo de diversas maneiras. Confirmo-a quando ouço de minha mãe que meu irmão foi parado por uma guarnição e submetido a uma verdadeira tortura psicológica durante duas horas, sob ameaças de forja de flagrante. Confirmo-a quando ouço de um amigo que foi interpelado por um policial com a seguinte frase: "minha mentira vale mais que sua verdade". A realidade mostra que o flagrante forjado é a "carta coringa" de certa parcela da polícia contra algumas pessoas $^{1}$.

Essas narrativas me fizeram pensar a todo tempo que tudo o que está escrito neste trabalho não é uma novidade, uma descoberta. Sei que essa é uma frase ruim para constar na introdução de uma tese. Mas insisto nela porque a realidade de uma polícia soberana, "dona da rua", é flagrante... "Todo mundo sabe"... Higor teria aprendido sobre essa soberania antes de entrar no curso de direito. P. não fez direito e sabia daquilo muito mais do que eu ou a maioria dos juristas.

Apesar disso, acreditava que seria importante expressar esse fenômeno em um trabalho jurídico ou sociojurídico, como acabou sendo. Falar sobre ele é expor isso à crítica, à reflexão. É expor a mim, jurista, a um desafio de sair da minha zona de conforto. E sistematizar e explicar a soberania policial não foi fácil; entender seus condicionantes, os fatores que contribuíam para esse fenômeno, como ele se manifestava foi um caminho árduo intelectualmente e pessoalmente. Penso que aqui há uma primeira versão desse esforço, mas que muito precisarei amadurecer para trabalhar uma temática tão complexa, mas, ao mesmo tempo, tão cotidiana. Lembro-me de ter visto Boaventura de Souza Santos um dia falar sobre as perguntas simples serem as mais difíceis de serem respondidas. Penso que "por que a polícia é dona da rua" é uma dessas questões.

Ainda mais complicado foi quando eu decidi falar sobre isso em outra época, há mais de cem anos. No primeiro capítulo desta tese, explicitarei as razões de minhas escolhas, algumas delas feitas pelas próprias contingências do trabalho de campo, isto é, não porque havia previsto que seria assim, mas porque fui levada pelos dados, pelas provocações e pelas leituras a tomar certas decisões.

Nesses percursos de pesquisa, nos questionamentos infindáveis sobre estar errando ou acertando nessas escolhas, fui, obviamente, indagada e assim me indaguei: "por que estudar a soberania policial no Recife do início do século XX e não no inicio do século XXI’? Uma das respostas mais honesta é a de que minhas pesquisas foram me encaminhando ao Arquivo

\footnotetext{
${ }^{1}$ ARAÚJO, Higor Alexandre Alves de. Culpados, mesmo com prova em contrário: uma análise jurisprudencial da alegação de flagrante forjado em prisões por tráfico de drogas no Tribunal de Justiça de Pernambuco. Trabalho de Conclusão de Curso. Faculdade de Direito do Recife-UFPE, 2017, p. 12.
} 
Histórico Estadual Jordão Emerenciano (APEJE), no Recife, e que todos aqueles livros, documentos e ofícios quase se apagando aguçaram a minha curiosidade.

Porém, antes disso, o que me levou ao arquivo foram as leituras sobre racismo e sistema punitivo, profundamente impactantes sobre mim e minha trajetória acadêmica. A formação social brasileira e seus trezentos anos de escravidão e o racismo reforçado pela ciência oitocentista, tão presente nos cursos jurídicos, foram estruturadores das agências do campo penal e dos seus códigos de atuação e, cada vez mais, senti-me impelida a entender isso, junto aos meus companheiros (as) de pós-graduação e de grupo de pesquisa. Assim, a história na qual esse sistema se forjou passou a constituir uma fonte de interesse.

Também, de 2014 a 2017, quando fiz essa tese, novas justificativas pareciam se construir. Após um longo período de instabilidade política criada por um grupo de políticos que ocupam o Congresso Nacional brasileiro, em 31 de agosto de 2016, Dilma Vana Rousseff foi destituída do cargo de presidenta da República. No seu lugar, o novo presidente iniciava um governo cujo lema era "Ordem e Progresso". "Que escolha infeliz!”, pensei inicialmente; “Que escolha adequada!”, refleti em seguida.

Os republicanos brasileiros que, em 1889, fundaram o novo regime, optaram por escrever na nossa bandeira o lema "Ordem e Progresso", de inspiração positivista e símbolo do tom civilizacional da época, anunciando um projeto de sociedade ordeira e moderna. A adequação parecia grande. Michel Temer e sua equipe, aliados a um congresso ainda de ruralistas, prometia sanar a vida política repleta de imoralidades e seu pacote ordeiro veio acompanhado de um retrocesso nas políticas sociais empreendidas nos últimos anos. O início do século XX por vezes me pareceu estar muito perto; mais do que nunca me interessava entender a gênese desse projeto...

O que significou ordenar para o progresso, entretanto, é uma discussão longa e que merece a atenção de outros trabalhos. A complexidade é tanta... $\mathrm{Na}$ época, muitos exescravizados aderiram às chamadas Guardas Negras para lutar contra essa República da ordem e do progresso e foram chamados por juristas como Rui Barbosa de "capoeiragem autorizada" e "um troço de maltrapilhos"2. A República, afinal, jamais significou a concretização efetiva de um projeto genuinamente público, de contemplação de interesses da coletividade. Até mesmo a primeira das Constituições do novo regime alijou uma parcela significativa da sociedade do básico direito de voto.

\footnotetext{
${ }^{2}$ SCHWACZ, Lilia M.; STARLING, Heloísa M. Brasil: uma biografia. São Paulo: Companhia das Letras, 2015, p. 312 .
} 
Fato é que "ordem e progresso" se define pelo seu oposto: "desordem e atraso". Desordem era um caso de polícia. Daí a centralidade dessas forças na dinâmica das cidades brasileiras no início do século XX. Atraso, por sua vez, foi, na época, definido como um problema das raças inferiores brasileiras. O cenário estava montado e, aparentemente, a peça, escrita.

As polícias foram convocadas para lidar com essa massa de pessoas - em sua maioria, negras - que passaram a ocupar as ruas das cidades, desempenhando trabalhos informais e estampando a pobreza que a estrutura agrário-escravista criara e que as políticas de embranquecimento e incentivo à absorção, nas indústrias, de mão-de-obra branca mantinha.

O sistema penal como um todo, é verdade, articula conceitos e institutos aptos a lidar com essa demanda, conforme destacarei. Tipos penais ou contravencionais acolheram em seus textos a conduta dos vagabundos, vadios, desordeiros, ébrios, menores abandonados, loucos... As teorias criminológicas, por sua vez, afirmavam que nem todos eram iguais e havia pessoas propensas à prática de delitos. Já as instâncias de punição prometiam curar esses indivíduos, educa-los à vida civilizada, se isso fosse possível; se não, ao menos recolhê-los, confina-los.

Porém, na prática e na imensa maioria das vezes, coube às polícias administrar esses problemas sem recorrer a longos processos judiciais ou à execução de penas privativas de liberdade fixadas por um juiz, após uma acusação formal. O espaço da soberania policial é o das decisões tomadas a critério de agentes policiais e não necessariamente da lei.

Portanto, "ordem e progresso" foi um assunto de polícia e isso estava estampado, por exemplo, nas narrativas da imprensa e nas músicas da época, assim como nos arquivos policiais. Ismael Silva, na década de 1920, compunha uma samba em que dizia, "Mas esta vida, não há quem me faça deixar. Por falares tanto, a polícia quer saber se eu dou meu dinheiro todo a você". Na década de 1950, Geraldo Pereira continuava a cantar essa presença policial: “A polícia tá no morro atrás do cabrito do doutor, que o Bento matou e fez tambor. O comissário mandou dizer que a escola só sai se o cabrito aparecer...”.

A polícia era a dona da rua. Todos sabiam e o campo jurídico também, mas é como se efetivamente partíssemos da premissa da banalidade do mal: "alguma coisa precisava ser feita". Dessa forma, entre liberdades dadas pela própria lei e a suspensão da ordem jurídica como alternativa, a polícia mantinha-se como soberana, tratando dos assuntos mais diversos da vida dos bairros pobres e negros brasileiros.

Este trabalho é um esforço de entender esse fenômeno.

No primeiro capítulo, aponto para os caminhos da pesquisa que me conduziram até esse objeto e procuro definir o conceito de "soberania policial", termo que tomei emprestado 
da obra de Vera Malaguti Batista. Traço as principais características de uma polícia soberana e os fatores que contribuíram para que ela se comportasse dessa forma. Os elementos constitutivos desse conceito foram descritos a partir da análise da prática policial no Recife do início do século XX, o que poderia supor se tratar de um argumento datado e ultrapassado. Porém, apesar dos cuidados que é preciso ter com o deslocamento no tempo de conceitos, creio ser possível ainda hoje falar de soberania policial, tão evidente na narrativa sobre P., feita no início desta introdução, ou naquela trazida por Higor.

Por certo, os meandros de uma polícia soberana hoje são outros, porque outras as compreensões acerca de liberdade, dos limites dessa atividade e da necessidade do controle sobre as polícias, assim como diversas as formas de resistência e oposição a essa prática. Grosso modo, entretanto, ainda temos muitas manifestações de policiais "donos da rua". Construir esse conceito a partir das condições sociais, econômicas, políticas e culturais de outra época pode ajudar a pensar em que contexto é possível ter polícias mais ou menos soberanas.

Ainda no primeiro capítulo, eu exponho as escolhas metodológicas que fiz, mormente do espaço e do período histórico analisados, além das fontes que utilizei para acessar esse passado. Essas delimitações são fundamentais para compreender, inclusive, os limites de um trabalho de tese, que, por certo, constitui apenas uma leitura possível de qualquer objeto. Ao decidir trabalhar com o Recife de 1915 a 1930, acessando basicamente fontes policiais e doutrina jurídica, eu perdi muitas informações valiosas sobre essa polícia soberana contidas na literatura, na imprensa, nos jornais, nas manifestações culturais, embora também tenha recuperado um saber oficial que movimentava e legitimava essas forças no cotidiano das cidades brasileiras. Qualquer trabalho acadêmico é incompleto e parcial e longe de ser um problema, esse é, certamente, o ponto de partida e a condição sem a qual os pesquisadores não renovariam seus olhares.

No segundo capítulo, dediquei-me a recuperar algumas dinâmicas das forças policiais brasileiras, imersas, desde o surgimento delas, em uma dicotomia que informava a sociedade escravocrata: violência e favor. Essas forças investiram historicamente nos corpos policiados, quando os açoites eram permitidos e mesmo quando deixaram de ser. Ao mesmo tempo, a polícia ofertava um espaço de resolução de conflitos a essa mesma população "torturável”, porque o acesso à justiça permanecia como um luxo para a elite branca brasileira. Desse modo, o patrimonialismo constituidor das burocracias brasileiras mesclava o desvirtuamento das funções públicas para satisfazer interesses particulares com a violência expressa no ato de vigiar, bater, dar baculejo, entrar a força em residências, espancar bêbados. 
O curioso é que as polícias - ao menos as suas cúpulas -, tanto a civil como a militar, tinham, no início do século XX, noção dessas características e pretendiam alterá-las. Ao menos publicamente. $\mathrm{O}$ discurso civilizatório que impregnava a intelectualidade brasileira foi reproduzido pelas forças policiais, gerando algumas reformas nas suas organizações. Também dedico um ponto do segundo capítulo a acessar esse sonho civilizatório, representado, no Brasil, pela figura de personagens como Sherlock Holmes, a antítese do "capoeira de farda", como se dizia à época: um policial branco, inteligente e que sabia se portar, que, por certo, abandonaria a velha polícia violenta e indisciplinada.

O terceiro capítulo é voltado a compreender como o campo jurídico contribuiu para a existência da polícia soberana. Afinal, teoricamente, essas forças não poderiam fazer nada a não ser em virtude da lei e, ao mesmo tempo, deviam satisfação ao poder judiciário sobre tudo o que faziam: prisões, investigações, abordagens etc. Na prática, não era bem assim e, em certo sentido, isso chegou a ser debatido por juristas do período e, em outros momentos, foi um aspecto ignorado. O capítulo expõe como as legislações penais e processuais penais do século XIX e início do século XX voltavam as suas atenções, em parte, àquele projeto de ordem e progresso, lido como perseguição aos desordeiros e atrasados. A grande chave para isso foi a gestão das contravenções, ilegalismos populares por excelência.

Vadiagem, jogo do bicho, embriaguez, mendicância e capoeiragem foi o pacote de ilicitudes que permitiu à polícia gerir as ruas. Já as atribuições a ela dadas pelas legislações processuais contribuíram enormemente para que o fizessem sem intervenção judicial. Em outras palavras, a polícia funcionou como uma justiça penal de primeira instância, processando, julgando e executando informalmente penas, sem direito a recurso. Cotidianamente, na cidade do Recife, por exemplo, cerca de dez pessoas eram presas e, alguns dias depois, soltas por ordem de delegados e subdelegados, sem processo, sem direito à ampla defesa ou ao contraditório.

Além dessas leis, o campo jurídico acabou contribuindo de outra maneira: silenciando. Afinal, como já dito, essas práticas eram de conhecimento de todos, mas não estavam substancialmente tratadas na doutrina processual penal, que deveria cuidar mais atentamente das atribuições das agências do sistema penal. Por fim, o campo jurídico foi também fundamental ao desenvolvimento desse fenômeno quando criava teses e interpretações de conceitos e institutos de maneira favorável à soberania policial, o que foi, por vezes, fruto do esforço de chefes de polícia que, como verdadeiros lobistas, procuravam, nos tribunais, amparo para suas ações. 
A Conferência Judiciária-Policial de 1917 é fruto desses acordos e encontros, um evento que reuniu, principalmente, policiais e juízes comprometidos com a necessidade de conter a desordem social. Ali, o judiciário, sobretudo membros do STF, deram carta branca às polícias. Nas ruas, continuar mantendo a ordem era um papel delas...

Nos três primeiros capítulos da tese, procurei definir o conceito de soberania policial e apontar para alguns fatores que favoreceram o fenômeno: sua estrutura burocrática patrimonial, sua participação como instância de resolução informal de conflitos, as leis penais e processuais penais, o silêncio do campo jurídico sobre seus excessos e os acordos políticos entre polícia e justiça, que significaram dar certa liberdade àquelas para gerir o espaço público.

Todas essas considerações podem ser feitas a respeito das polícias em geral. Já o quarto capítulo mergulha no cotidiano da polícia recifense e procura compreender as dinâmicas dela. Como policiais de base, delegados, subdelegados e chefes de polícia ordenavam suas ações em busca dos desordeiros da cidade, esses, sem dúvidas, os principais alvos de uma polícia soberana?

Invisto algumas páginas a apresentar as estatísticas oficiais da polícia, apontando, agora em números, para a enorme centralidade das contravenções e suas prisões sem processo na dinâmica policial. Em seguida, resgato algumas narrativas das ocorrências envolvendo aqueles que compunham a imagem da desordem. Estruturo essas ocorrências em três blocos: a polícia ordeira e a repressão aos vadios, menores, ébrios e mendigos; a polícia moral e a gestão das mulheres indisciplinadas e a polícia política e a vigilância e administração dos operários organizados.

Todos eles, sem dúvidas, os inimigos do progresso republicano, permearam as folhas policiais, o que, aliás, vem sendo objeto de estudos desde a década de 1980, sobretudo no campo da história em geral, e da história das polícias, em especial.

O quinto e último capítulo é praticamente um desdobramento do quarto, momento em que procuro entender o que a polícia pretendia fazer com esses desordeiros e o que efetivamente faziam. É também um capítulo sobre práticas da soberania policial, que, curiosamente, iam de encontro aos discursos da corporação na época, os quais, de cunho fortemente correcionalista, acompanhando as tendências das escolas criminológicas do período e o senso comum, viam os desordeiros como seres passíveis de serem educados e treinados para vida correta e para o trabalho.

O sonho civilizatório é disciplinar e, aqui, a conversa com a obra de Michel Foucault será inevitável. Porém, entre a utopia disciplinar e a prática, há um abismo. Um abismo 
permeado de um padrão de atuação muito mais acostumado e dado aos acordos, negociações, corrupção, violência, arbitrariedades, jeitinho... Era o velho patrimonialismo e sua conjugação de violência e favor, que resistiria aos projetos de disciplinamento da alma, preferindo - ou mesmo não encontrando alternativas a isso - o velho disciplinamento à força, pelo açoite, atuando sobre corpos.

Afinal, e essa reflexão permeará todo o texto, o controle penal no Brasil se desenvolveu principalmente gerindo corpos sem alma. O racismo constituiu o sistema penal, deu a ele sentido, apresentou a ele verdades. Criou tipos penais e o estereótipo dos desviantes, legitimou suas práticas, naturalizou a sua violência. Permitiu, enfim, que no espaço da rua das ruas, por certo, dos bairros pobres e negros, da Pequena África no século XIX, do bairro de Santo Antônio no Recife do início do século XX ou dos Coelhos e do Coque (vizinhos, aliás) do início do século XXI - prevalecesse a força e o poder informais de policiais, para quem os códigos do favor e da violência pareciam imperar sobre o da lei. 


\section{CAMINHOS E PERCALÇOS DA PESQUISA EM BUSCA DA COMPREENSÃO DO CONTROLE POLICIAL NO INÍCIO DO SÉCULO XX}

\subsection{TRAJETÓRIAS EM CAMPO ATÉ A DELIMITAÇÃO DO OBJETO}

Eu estava sentada fora da delegacia, esperando a chegada de alguma ocorrência. Chegou uma viatura da polícia militar, um carro Gol. Do banco da frente saíram dois policiais e do banco traseiro, uma menina com camisa de escola pública estadual e um homem mais velho, todos negros. Naquele momento, tentei deduzir do que se tratava a ocorrência e pensei que fosse alguma questão relacionada a tráfico ou uso de droga em escolas, como acontecia de vez em quando. Mas, alguns minutos depois, um dos policiais abriu a mala do gol e, de dentro dele, tirou um menino, de uns 17 anos de idade, alto, negro, muito magro e com os braços algemados e voltados para trás. A camisa dele estava toda melada de barro, como, aliás, muitos meninos chegam. Assim que ele saiu do carro, o policial falou bem alto: "cagasse foi, boy?" e depois continuou dizendo que a mala estava toda "cagada". O adolescente permaneceu calado e tentava, abaixando a cabeça e dobrando o corpo, colocar de volta na cabeça um boné vermelho que tinha nas mãos algemadas. Ele tentara roubar a menina na frente da escola minutos antes e teria sido, segundo a versão apresentada pelos policiais, linchado. Com a chegada da polícia, ele teria sido "resgatado" e conduzido até a delegacia. (Diário de campo, 24 de setembro de 2015)

Essa cena, vivenciada por mim e outros dois pesquisadores do Grupo Asa Branca de Criminologia, Maurilo Sobral e Fernanda Lima $^{3}$, ficou registrada como uma imagem da qual me lembrei dezenas de vezes ao longo da elaboração desta tese. Naquele momento, eu começava uma etnografia na Delegacia de Proteção à Criança e ao Adolescente na cidade do Recife, onde pretendia investigar o fluxo de criminalização de adolescentes. Por alguns meses, frequentei semanalmente aquela unidade policial e vi muitas ocorrências envolvendo jovens negros do sexo masculino como a daquele que saíra "cagado" do Gol. Porém, em nenhuma delas eu tinha me deparado com tamanha desumanização.

Àquela altura, também já estava no segundo ano do doutorado na Universidade de Brasília e passara por muitas discussões em sala de aula e fora dela sobre racismo e sistema punitivo, um tema que, até então, não fizera parte de modo significativo de minha formação acadêmica. Depois, ao ler autores e autoras contemporâneas, que trabalham com a campo

\footnotetext{
${ }^{3}$ Essa pesquisa na Delegacia de Proteção à Criança e ao Adolescente na cidade do Recife, realizada em conjunto pelo Grupo Asa Branca de Criminologia, foi a base da dissertação de mestrado de Maurilo Sobral, defendida em 2016, no Programa de Pós-Graduação em Direito da Unicap, intitulada "Sobre os que não têm jeito: racismo institucional e a identificação do adolescente suspeito a partir da atuação da polícia na cidade do Recife" e do trabalho de conclusão de curso de direito de Fernanda Lima, na Faculdade de Direito do Recife, intitulado "Policiados e policiais. Dois tempos de uma história de criminalização", apresentado em 2016.
} 
penal, como Ana Luiza Flauzina, Felipe Freitas, Luciano Góes, Naila Franklin, Gabriela Sá, Gisela Wanderley e Bruna Portella de Novaes, dentre tantos outros, entendi que a criminologia crítica, um de meus principais referenciais teóricos, e suas ricas contribuições à compreensão dos sistemas punitivos latino-americanos deitavam suas origens, majoritariamente, em concepções críticas de linha marxista, cuja principal chave interpretativa para os fenômenos sociais é a divisão entre classes, ficando em segundo plano a questão racial $^{4}$.

Meu projeto de tese começou, então, a se modificar. Aos poucos passei a pensar que a "questão racial" deveria fazer parte dele, porque, inevitavelmente, eu já começava a me interpelar sobre os vários pontos cegos das teorias com as quais comumente trabalhava. Ao mesmo tempo, as visitas à DPCA me fez presenciar e passar por situações que me embaraçaram profundamente e lembravam que ser uma pesquisadora branca naquele espaço me abria algumas oportunidades. A começar pelo acesso fácil à delegacia, onde fui bem tratada por policiais civis e por delegados, quase todos brancos como eu, com formação escolar e universitária nos mesmos lugares que eu e até mesmo pertencentes a ciclos de amizade em comum.

Não quer dizer que, como mulher e em um ambiente marcadamente machista, eu não tenha precisado driblar apertos de mãos excessivos, olhares insinuados ou comentários fora do lugar. Porém, também não me faltou certa cortesia em um ambiente que carece muito dela. Exemplo disso se deu em relação ao uso do sanitário.

No térreo da DPCA, onde ficam os cartórios e a sala de espera de detidos e familiares, há apenas um banheiro masculino. Quando dei conta disso, pensei imediatamente se as adolescentes apreendidas se sentiriam à vontade naquele espaço, mesmo sendo menos representativas em termos quantitativos. A priori pensei que aquela situação era a expressão do já muito abordado no campo criminológico "forgotten few" : por serem menos presentes nesses espaços, as adolescentes são esquecidas. E eram esquecidas mesmo. Porém, a vivência na delegacia me fez dar conta de que não há poucas mulheres naquele lugar, pois ali circulam diariamente dezenas de mães dos adolescentes.

$\mathrm{Eu}$, pesquisadora, havia sido informada por um escrivão, logo nas minhas primeiras idas ao local, de que, no $1^{\circ}$ andar do prédio onde se localizava a DPCA, havia dois banheiros,

\footnotetext{
${ }^{4}$ Um artigo fundamental para essa crítica é: PIRES, Thula Rafaela de Oliveira. Criminologia crítica e pacto narcísico: por uma crítica criminológica apreensível em pretuguês. Revista Brasileira de Ciências Criminais. Ano 25, v. 135, p. 541-562, set, 2017.

${ }^{5}$ BERGSMANN, Ilene R. The forgotten few: Juvenile female offenders. Federal Probation, 53(1), p. 73-78, 1989.
} 
um masculino e um feminino, mais limpos, arejados e cheirosos, talvez, portanto, mais adequados para eu fazer uso. Ele havia tido comigo esse cuidado, o qual não era dispensado às presas - a quem eu poderia esperar que não fosse mesmo -, mas também àquelas mães, que ali não encontravam qualquer amparo.

Aliás, essas mulheres também me provocaram muito com suas presenças constantes, com seus choros, com seus atos de desconsolo. Nunca esqueci de um menino, negro, muito baixo, de uns 12 anos, que olhou para sua mãe e disse: "tu não sabia que era assim, mainha?". O policial que a recebera dissera algo parecido: “é assim mesmo". Ela só chorava e eu, encabulada, não fazia ideia de como aquilo poderia ou até se deveria se transformar em um objeto de pesquisa.

Reunindo as leituras, as vivências e as provocações de colegas pesquisadores, decidi que dedicaria um capítulo da minha tese à história do sistema punitivo. Estava convencida de que os traços econômicos, sociais e culturais de nossa sociedade oitocentista, quando se formaram importantes bases de nosso aparato punitivo - incluindo a polícia -, poderiam explicar a presença marcante de pessoas negras no grupo de criminalizáveis e também a construção da desumanidade desses corpos. Ao mesmo tempo, e cada vez mais isso passava a me interessar, no Império e na República, os caminhos para os espaços de poder e decisão sobre o sistema penal - do legislativo ao judiciário - estavam abertos praticamente apenas para homens brancos, quase todos formados em faculdades de direito.

Seguindo essa linha, construí meu projeto de qualificação de tese em duas partes: uma sobre esse apanhado histórico e outra sobre a criminalização de jovens negros pelo sistema de justiça juvenil. Fui submetida à banca e de lá saí com a certeza de não poder escrever sobre os dois momentos, pois me faltava fôlego e tempo. Na banca, alguns professores sugeriram ir um pouco mais afundo nas análises históricas e no cotidiano da criminalização no Recife.

Optei, portanto, por me dedicar somente à análise histórica, mesmo não sendo historiadora e nunca tendo antes trabalhado com essa perspectiva. Por outro lado, eu já tinha frequentado o Arquivo Público Estadual Jordão Emerenciano (APEJE), localizado no centro da cidade do Recife, no bairro de São José, para fazer um trabalho de finalização da disciplina "Criminologia e Racismo", do professor Evandro Piza Duarte, quando me dediquei ao tema do controle policial sobre mulheres no início do século XX. Tinha gostado muito de folhear documentos históricos e recuperar informações literalmente condenadas a se apagar e foi para lá que eu voltei a partir de agosto de 2016 e de onde não saí até os últimos meses de elaboração desta tese. 
Minhas leituras e revisão bibliográfica estavam centradas, até então, na polícia e no fluxo do sistema de justiça criminal, seus gargalos e suas escolhas. Retomando as atividades no arquivo, entretanto, minha atenção se voltou aos estudos sobre as práticas policiais no início da República, momento em que descobri uma rica bibliografia sobre a história das polícias, produzida, sobretudo, no campo da história. Foram elas fundamentais no desenvolvimento de meus argumentos.

Voltando ao arquivo, inicialmente realizei leituras exploratórias nos documentos policiais. Contei com o apoio prestimoso dos funcionários do arquivo, sobretudo dos historiadores Hildo Leal da Rosa e Emerson, que me levaram a fontes as mais variadas, desde ofícios de delegados, subdelegados e chefes de polícia a livros de registros de prisões da Casa de Detenção do Recife. Manuseei e fotografei muitas folhas e as fui analisando cuidadosamente até chegar, finalmente, à problemática central desta tese, que passou era um dos aspectos das práticas das polícias, tanto a administrativa quanto a judiciária, no Recife: a autonomia com que agiam.

Sem dúvidas, embora eu tenha ido ao arquivo com algumas leituras e hipóteses sobre a construção do sistema punitivo no Brasil, sobre o modo de operar das polícias no período e sobre o público alvo dessas agências, as narrativas do arquivo falaram mais alto e acabaram me conduzindo a reformular as perguntas de pesquisa.

A princípio essa reformulação gerou em mim um pouco de angústia, porque passei a pensar que estaria fugindo ao meu tema ou, pior, que estaria desperdiçando muito tempo de atividade na coleta de dados que não me levariam a lugar algum. Insisti, entretanto, nesse percurso exploratório, deixando o campo me surpreender.

Deixar que as impressões dadas pelo próprio campo e que os dados encontrados falem um pouco mais alto e apontem para problemáticas antes não vislumbradas pode constituir uma oportunidade de avançar na interpretação do fenômeno estudado. Howard Becker fala em "deixar o caso definir a categoria" ao se referir a esse processo dinâmico de restruturação da pesquisa promovido pela própria imersão na investigação. Para ele, as pesquisas em ciências sociais costumam se orientar em sentido inverso, buscando "encaixar" o caso a categorias preestabelecidas. $\mathrm{O}$ preço, entretanto, é não ver ou não dar atenção a aspectos que não estavam previamente contidos na categoria com a qual se começa a investigação ${ }^{6}$.

O esquema clássico da metodologia da pesquisa que impõe uma ordem de fatores em que as hipóteses são formuladas e, em seguida, testadas por um método para serem refutadas

\footnotetext{
${ }^{6}$ BECKER, Howard. Segredos e truques da pesquisa. Rio de Janeiro: Jorge Zahar Editor, 2007, p. 163.
} 
ou confirmadas definitivamente não representava o que eu havia feito. Invertendo os passos, Omnès pensa a construção do conhecimento científico partindo da etapa de observação. Para o autor, essa atividade se dá em quatro tempos: empirismo (momento em que se observa algum fenômeno tido como objeto), conceptualização (quando se elabora conceitos para representar o objeto), elaboração (refinamento teórico dos conceitos) e verificação (momento em que a teoria formulada pode ser posta à prova $)^{7}$. Entendo que essa formulação é mais adequada, mas com uma ressalva.

Quando assevero que os dados que coletei acabaram por informar mais detidamente as minhas perguntas de pesquisa, não pretendo concluir que eu fui a campo, observei e vi o dado, que ali se encontrava pronto e acabado para ser descoberto. A superação de certas premissas do positivismo científico é incontornável, dentre elas a de que a sociedade pode ser observada e explicada por um sujeito neutro. Afinal, chegar aos dados já é um percurso permeado de escolhas. Qual o meu objeto? Por que o escolhi? Para onde irei a fim de examiná-lo? Que perguntas farei? Que fontes consultarei? Que métodos empregarei? Essas perguntas precisam ser enfrentadas e respondidas.

Pierre Bourdieu nos fala da necessidade de uma objetivação da relação do sociólogo com o seu objeto. Entender o porquê do interesse do pesquisador sobre o objeto e a razão pela qual o estudioso investe nele é uma ruptura fundamental para que o conhecimento se invista de alguma possibilidade de objetividade ${ }^{8}$. A mesma observação cabe para juristas que emergem em investigações sociojurídicas ou sócio-históricas.

Esse processo de escolhas pessoais até o tema e o campo da pesquisa não pode, portanto, ser neutro, pois, ao contrário, “a seleção do corpus obedece também a razões estratégicas" ". No tocante aos estudos historiográficos na área do direito, essa perspectiva se associa à forma como as narrativas de documentos são percebidas. As fontes históricas não são simples relatos de fatos sequenciados, elas dependem "das perguntas que a ela são feitas pelo sujeito de conhecimento, e estas mediam o acesso às realidades pretéritas, cuja reconstituição na totalidade de seus elementos é impossível" ${ }^{10}$.

Desse modo, ir até as fontes é ir com certa bagagem axiológica da qual o pesquisador não se despe por completo. Por outro lado, ler as fontes é extrair dela fatos, números, falas e

\footnotetext{
${ }^{7}$ OMNÈS, Roland. Filosofia da ciência contemporânea. São Paulo: Editora UNESP, 1996, p. 223-285.

${ }^{8}$ BOURDIEU, Pierre. O poder simbólico. 15a ed. Rio de Janeiro: Bertrand Brasil, 2011, p. 58.

${ }^{9}$ POSSENTI, S. O dado dado e o dado dado: o dado em análise do discurso. POSSENTI, S. (org.). Os limites do discurso: ensaios sobre discurso e sujeito. Curitiba: Criar Edições, 2 ed, p. 27-36, 2004, p. 30.

${ }^{10}$ LIPNITZ, Guinter. Pesquisa historiográfica e documental: diálogos entre História e Direito a partir de escrituras públicas de contratos. MACHADO, Maíra Rocha. (org.) Pesquisar empiricamente o direito. São Paulo: Rede de Estudos Empíricos em Direito, p 225-248, 2017, p. 227.
} 
índices sem que possamos arbitrariamente descartar ou ignorar essas informações. Para Luciano Oliveira, "é no instante de colher na realidade empírica o apoio factual sistematicamente controlado - e só nesse instante - que o pesquisador deve adotar uma postura neutra" 11 , que certamente não existirá na interpretação desses mesmos dados, mas que não deve fazer o pesquisador ficar com o que confirma sua hipótese e deixar de lado o que infirma.

Dito isto, volto à reflexão sobre a construção das perguntas da pesquisa a partir do trabalho empírico. De fato, muito do que li naqueles documentos confirmava hipóteses já estabelecidas a partir de minhas leituras prévias sobre o tema. Não foi, portanto, uma surpresa verificar que a polícia, no Recife, no início da República, voltava a sua atenção a desordeiros, a vagabundos, a prostitutas, a jogadores, a ébrios e a menores abandonados, as imagens em si do perigo social nas cidades em vias de modernização.

Porém, além dessas informações, encontrei nos documentos presos assinando habeas corpus endereçados ao chefe de polícia, prisões sendo realizadas por delegados e subdelegados sem qualquer comunicação à justiça e sem que os casos criminais chegassem a se tornar processo, pessoas recorrendo à polícia para pedir ajuda na cobrança de alugueis, policiais militares disputando poder nas ruas com guardas civis. Enfim, verifiquei vários sinais de uma polícia que, naquele ambiente e em relação a um determinado grupo de pessoas, funcionava efetivamente como "dona da rua" e instância autônoma de resolução de conflitos criminais ou não.

Foi então que o termo "soberania policial", utilizado por Vera Malaguti Batista no livro "O medo na cidade do Rio de Janeiro", passou a fazer bastante sentido. Para a autora, a polícia soberana é aquela que atua no espaço público ou privado da maneira como julga pertinente e conveniente, sem, a princípio, sofrer constrangimento por parte da lei, do poder judiciário ou de outras instâncias ${ }^{12}$. Essa era a face da polícia carioca no início e em meados do século XIX, mas parecia-me uma interessante imagem para pensar também a polícia no Recife, no início do século passado.

Assim, fui-me aproximando, aos poucos, do que seria o objeto desta tese, a "soberania policial", cujo conceito tentarei aqui delinear, problematizando, antes, ainda a atividade policial no período.

\footnotetext{
${ }^{11}$ OLIVEIRA, Luciano. Neutros \& Neutros. Humanidades, n. 19, Brasília, p. 122-127, 1988, p. 124.

${ }^{12}$ BATISTA, Vera M. O medo na cidade do Rio de Janeiro: dois tempos de uma história. Rio de Janeiro: Editora Revan, 2003.
} 


\subsection{PROBLEMÁTICAS}

Essa sinistra morada era habitada por uma personagem talhada pelo molde mais detestável; era um caboclo velho, de cara hedionda e imunda, e coberto de farrapos. Entretanto, para a admiração do leitor, fique-se sabendo que esse homem tinha por ofício dar fortuna ${ }^{13}$. (...) E não era só a gente do povo que dava crédito às feitiçarias; conta-se que muitas pessoas da alta sociedade de então iam às vezes comprar venturas e felicidades pelo cômodo preço da prática de algumas imoralidades e superstições. Pois ao nosso amigo Leonardo tinha-lhe também dado na cabeça tomar fortuna, e tinha isso por causa das contrariedades que sofria em uns novos amores que lhe faziam agora andar a cabeça à roda. (...) Começando a cerimônia, o Leonardo foi obrigado a ajoelhar-se em todos os ângulos da casa, e recitar as orações que já sabia e mais algumas que lhe foram ensinadas na ocasião, depois foi orar junto da fogueira. (...) De repente, sentiram bater levemente na porta de fora e uma voz descansada dizer: - Abra a porta.

- O Vidigal! - disseram todos a um tempo, tomados do maior susto. ${ }^{14}$

A cena que se segue é a de uma das violentas investidas do Major Vidigal sobre todos os participantes da cerimônia. "Toca, granadeiros", ele diria a seus capangas, que se soltaram a dar chibatadas na "gente honesta", tal qual referida por Manuel Antônio de Almeida. Vidigal foi um dos mais expoentes membros da Guarda Real de Polícia, criada em 1809, após a vinda da família real ao Brasil. A guarda atuava em tempo integral, era militarizada e tinha ampla autoridade para manter a ordem nas cidades. Segundo Thomas Holloway, Vidigal "tornou-se o terror dos vadios e ociosos, que podiam encontra-lo ao virar uma esquina à noite ou vê-lo aparecer de repente nos batuques que aconteciam com frequência nos arredores da cidade"15. A cena elaborada por Almeida parece, portanto, fiel aos números policiais da época.

De acordo com os registros de suas apreensões realizadas entre 1810 e 1821, $80 \%$ dos presos eram escravos e 19\%, ex-escravos. Portanto, 99\% dos alvos do Major eram negros. Dentre as condutas que mais geravam apreensões estavam as de ofensas à ordem pública, como a capoeira e a desordem em grupo (41,2\%), as fugas de escravos $(18,8 \%)$ e os delitos contra o patrimônio $(23 \%)^{16}$.

\footnotetext{
${ }^{13}$ Adivinhar o futuro.

${ }^{14}$ ALMEIDA, Manuel Antonio de. Memórias de um sargento de milícias. São Paulo: Editora Ática, 1998, p. 2425.

${ }^{15}$ HOLLOWAY, Thomas H. Polícia no Rio de Janeiro: repressão e resistência numa cidade do século XIX. Rio de Janeiro: Editora FGV, 1997, p. 48.

${ }^{16}$ HOLLOWAY, Thomas H. Polícia no Rio de Janeiro: repressão e resistência numa cidade do século XIX. Rio de Janeiro: Editora FGV, 1997, p. 52.
} 
Mas, o que Vidigal teria a dizer sobre a polícia no início da era republicana? Sem dúvidas, nos tempos dele, o Brasil era uma colônia e a polícia acabara de surgir como organização, de modo que, ao observar a sua atuação, não podemos fazer simples transposições para o início do século XX, período a que se dedica este trabalho.

O padrão de policiamento do Império e da República correspondeu a aspectos específicos das sociedades de seu tempo e suas atuações também estavam atreladas a espaços de experiência e horizontes de expectativas muito peculiares. Essas duas categorias, "espaço de experiência" e "horizonte de expectativas", cunhadas por Reinhart Koselleck, advertemnos sobre a necessidade de evitar comparações entre épocas históricas sem considerar o espaço e tempo em que os fenômenos e conflitos sociais se deram.

A experiência está ligada ao passado, à incorporação de fatos ocorridos, à lembrança que se acumula. Já a expectativa remete ao que pode ser previsto. "Esperança e medo, desejo e vontade, a inquietude, mas também a análise racional, a visão receptiva ou a curiosidade, fazem parte da expectativa e a constituem"17, destaca o autor. A experiência é, assim, o passado atual e a expectativa, o futuro presente.

As vivências sobre o passado $\mathrm{e}$ as expectativas sobre o futuro moldam comportamentos individuais e coletivos e também interferem nos processos de atribuição de sentido. O que significava revolta ou liberalismo no final do século XVII certamente não era o mesmo no início do século XX, por exemplo, e assim por diante. A principal tese de Koselleck é a de que, na modernidade, a diferença entre experiência e expectativa se distancia muito, porque as mudanças ocorrem de forma rápida, acelerada e praticamente imprevisível. O que as sociedades viveram não é o que vivem no presente e elas não podem determinar com precisão o que será do futuro.

O que pode ser tomado dessa elaboração, aqui, é a necessidade de se pensar policiamento, expectativa de ordem pública, liberdade, liberalismo, controle judicial e tantos conceitos, ideias e práticas com os quais laborarei ao longo do trabalho necessariamente a partir do espaço e tempo em que se desenvolveram, evitando, assim, anacronismos.

As forças policiais que atuavam nos espaços urbanos, no início do século XIX, estão primordialmente voltadas ao controle da população negra - livre ou cativa - em um sistema escravocrata. Embora os sopros das Declarações de Direitos francesa e americana se fizessem presentes na Constituição de 1824, tratava-se de uma sociedade que, oficialmente,

\footnotetext{
${ }^{17}$ KOSELLECK, Reinhart. Futuro passado. Rio de Janeiro: Contraponto Editora, 2006, p. 310.
} 
hierarquizava o direito à vida e à dignidade a partir de um critério de racialização que distinguia os "homens brancos" dos "homens de cor" e que, no próprio processo constituinte de 1823, sabia delimitar claramente a igualdade e a liberdade que os brancos queriam. Marcos Queiroz destaca a presença de um deputado constituinte, José Severino Maciel da Costa, que tornou conhecido o termo "haitianismo", e que, em seus escritos, "aponta o perigo das ideias contagiosas de liberdade e igualdade, as quais inflamaram a cabeça dos africanos nas colônias francesas" $"$.

Naquele momento, existia uma demanda por ordem pública que estava diretamente relacionada aos riscos de rupturas políticas protagonizadas por republicanos e independentistas nacionalistas, mas, também pela população negra. Uma série de revoltas negras, como a dos Malês na Bahia, estourou pelo território brasileiro, alimentando o medo branco de uma onda negra, como referiu Célia Marinho de Azevedo, e, além disso, a sombra da revolução haitiana, ocorrida em São Domingos, em 1791, pairava como uma ameaça às estruturas econômicas e políticas daquele tempo, fato evidente no discurso de Maciel da Costa, como dito no parágrafo anterior.

Marcos Queiroz demonstra também como a Revolta de Santo Domingos ressignificou, inclusive, outros processos de insurreições programadas ou existentes no Brasil, naquele período. Na revolução pernambucana de 1817, por exemplo, apesar de seu caráter republicano, mas não necessariamente abolicionista, a participação de negros teria tensionado e pressionado a se inserir a igualdade racial como uma bandeira. "Com o aumento da participação popular na fase inicial do movimento, negros e negras enxergaram no 'tempo da Pátria' da Revolução Pernambucana um tempo também de igualdade racial" ${ }^{19}$ e não faltaram alusões ao haitianismo por parte dos membros do governo convocados para reprimir o movimento.

Noutro contexto, nos processos de Independência da Bahia (1821-1822), brasileiros reivindicavam a independência em relação a Portugal, mas dependiam da força das classes populares, as quais, por sua vez, composta de negros escravos ou libertos, inseriam a pauta da abolição, pois "na nascente do processo de Independência, a população negra via o momento como uma oportunidade histórica para por fim ao cativeiro, tendo nesse aspecto um dos

\footnotetext{
${ }^{18}$ QUEIROZ, Marcos. Constitucionalismo brasileiro e o atlântico negro: A experiência constitucional de 1823 diante da Revolução Haitiana. Dissertação de mestrado. Programa de Pós-Graduação em Direito. Universidade de Brasília. 2017, p. 113.

${ }^{19}$ QUEIROZ, Marcos Vinícius Lustosa. Constitucionalismo brasileiro e o atlântico negro: A experiência constitucional de 1823 diante da Revolução Haitiana. Dissertação de mestrado. Programa de Pós-Graduação em Direito. Universidade de Brasília. 2017, p. 106.
} 
motivos da sua forte participação nos eventos da época"20, passando a representar uma ameaça à luta pela independência capitaneada pelos brancos.

Enfim, esse medo, sobre o qual falarei melhor depois, não era um delírio individual, mas um sentimento pulverizado na elite branca brasileira, que, efetivamente, deu rumo a projetos políticos e legislativos e, no campo criminal, construiu discursos e orientou práticas.

Por outro lado, pensar o controle policial no Império é não esquecer que ele ocorria em concomitância com um sistema penal privado, assim como se dava no período colonial. Havia o poder dos proprietários de escravos de punir e o do Estado. Às vezes, o sistema público confrontava o privado e às vezes o complementava. Nilo Batista desenvolve esse argumento em Pena pública e escravismo.

Partindo do caso de cinco escravos que assassinaram um capataz ${ }^{21}$, Batista explora os bastidores do processo criminal $^{22}$. Primeiramente, o dono dos escravos não desejava que a vítima fosse qualificada como capataz, posto que isso levaria, em eventual condenação, à pena de morte e, consequentemente, à perda de sua propriedade (os cinco escravos). Já o fiscal de acusação, por outro lado, deixou de pronunciar dois dos escravos, porque entendeu que eles não teriam efetivamente concorrido para a morte e estavam tentando se autoincriminar para se livrar do cativeiro da escravidão e serem presos, afinal, como lembra Batista, a pena pública era muitas vezes tida como mais confortável e menos severa que a violência escravocrata ${ }^{23}$. Por fim, os jurados teriam acolhido o apelo dos advogados dos escravos - nomeado pelo seu dono - e teriam apresentado a melhor das saídas para a manutenção de sua propriedade: apenas três escravos condenados e não à pena de morte, mas a quinhentos açoites, pois a qualidade de "capitão do mato" da vítima fora afastada.

A partir dessa narrativa, Nilo passa a refletir sobre as possíveis relações entre os âmbitos público e privado da penalidade. Às vezes, tratava-se de uma relação conflituosa e existiam os choques de interesse, como no caso mencionado ou nas tentativas régias e das

\footnotetext{
20 QUEIROZ, Marcos Vinícius Lustosa. Constitucionalismo brasileiro e o atlântico negro: A experiência constitucional de 1823 diante da Revolução Haitiana. Dissertação de mestrado. Programa de Pós-Graduação em Direito. Universidade de Brasília. 2017, p. 109.

${ }^{21}$ Crime, à época, sujeito à pena de morte.

22 BATISTA, Nilo. Pena pública y esclavismo. Coleccion Intercambios. Caracas: Universidad Nacional Experimental de la Seguridad, 2012.

${ }^{23}$ Clarissa Nunes Maia faz a mesma observação em seu trabalho. Muitos escravos preferiam ser recolhidos a unidades prisionais, porque aquilo não representava a perda da liberdade - que já não tinham e nas fazendas ou casas particulares eram, por vezes, submetidos a tratamentos crueis. MAIA, Clarissa Nunes. Sambas, batuques, vozerias e farsas públicas: o controle social sobre os escravos em Pernambuco no século XIX (1850-1888). São Paulo: Annablume, 2007, p. 56.
} 
câmaras municipais em limitar a crueldade com que os castigos eram aplicados aos escravos $^{24}$, o que desagradava os proprietários.

Porém, para além desses conflitos, havia uma coerência no comportamento da justiça pública em relação aos interesses dos senhores de engenho. Os limites à crueldade da pena, sobretudo a de açoite, por exemplo, podiam ser pensados como estratégia de manutenção da propriedade senhorial $^{25}$ e da ordem na cidade, afinal escravos inválidos representariam um peso maior para o Estado do que para seu dono, já que eram frequentemente alforriados, passando a ocupar as ruas das cidades.

A pena de morte, por seu turno, poderia ser mais ou menos utilizada e defendida a depender da oferta de mão de obra escrava. A graça dada pelo rei, que, na prática, representava a dispensa do cumprimento da pena de morte, era menos frequente em épocas de abundância de mão de obra escrava, passando-se o contrário em períodos de escassez de mão de obra ${ }^{26}$.

Neste cenário de controle público e privado, as forças policiais buscavam promover a ordem e possuíam - como será exposto no próximo capítulo - uma organização burocrática marcadamente patrimonial, representando interesses particulares e do Império ao mesmo tempo. Nas ruas, eram soberanas, como descreve Vera Malaguti, e perseguiam e prendiam escravos fujões e insurgentes, encaminhando-os ao Calabouço, uma prisão pública que servia para mantê-los de castigo e para dar exequibilidade à pena de açoite. Na unidade, esses corpos eram açoitados a pedido de seus donos ou por ordem policial ou judicial, no caso de prática de crimes. No primeiro caso, os donos deveriam arcar com os custos para a manutenção de suas propriedades $^{27}$.

No início da República, esse cenário se altera em vários aspectos, trazendo à tona novas configurações sociais, econômicas e políticas. Os primeiros anos do novo regime foram, como se sabe, bastante instáveis. A primeira Revolta da Armada, protagonizada por oficiais da Marinha - que se sentiam negligenciados em relação ao Exército -, levou à

\footnotetext{
${ }^{24}$ Por meio de vários Avisos, D. Pedro I tentou limitar o uso do açoite, exigindo que essa pena fosse aplicada de forma razoável. Também se tentou disciplinar a execução dessa punição por meio das posturas municipais. Antonio Feijó, ministro da justiça entre 1831-1832, também procurou limitar o uso dos açoites, em termos de número deles e limite que cada escravo poderia sofrer.

${ }^{25}$ MAIA, Clarissa Nunes. Sambas, batuques, vozerias e farsas públicas: o controle social sobre os escravos em Pernambuco no século XIX (1850-1888). São Paulo: Annablume, 2007, p. 55.

${ }^{26}$ BATISTA, Nilo. Pena pública y esclavismo. Coleccion Intercambios. Caracas: Universidad Nacional Experimental de la Seguridad, 2012, p. 50.

${ }^{27}$ Holloway afirma que, em 1820, o custo para cada escravo mantido na prisão seria de cerca de 200 reis: 160 para os açoites e 40 para a subsistência. Para termos ideia da quantidade de escravos que circulavam por essa prisão pública, naquele ano, foram chicoteados 1.786 escravos, sendo 262 deles mulheres . Ver: HOLLOWAY, Thomas H. O calabouço e o Aljube do Rio de Janeiro no século XIX. MAIA, C. N.; SÁ NETO, F. de; COSTA, M.; BRETAS, M. L. (orgs) História das prisões no Brasil. Volume I. Rio de Janeiro: Rocco, 2009, p. 256.
} 
renúncia de Deodoro da Fonseca já em 1891, tendo ele sido sucedido por Floriano Peixoto. $\mathrm{Na}$ era do "florianismo", a Revolução Federalista do Sul eclodiu, bem como uma nova Revolta da Armada, em 1893. Ao mesmo tempo, políticos liderados pelo Partido Republicano Paulista pretendiam assumir o governo, pacificar o país e estabelecer definitivamente os interesses das oligarquias cafeicultoras do sudeste ${ }^{28}$. Foi assim que se sucedeu com a eleição, em 1894, de Prudente de Morais.

Os próximos anos seriam de fortalecimento das elites locais, em uma dinâmica que se cunhou de "Política dos Governadores" e de domínio dos oligarcas de Minas Gerais e de São Paulo. Como destacam Schwarcz e Starling,

[...] a estabilidade política da República estava garantida por três procedimentos principais: empenho dos governos estaduais em manter o conflito político confinado à esfera regional; reconhecimento por parte do governo federal da plena soberania dos estados no exercício da política interna; manutenção do processo eleitoral em que, a despeito dos mecanismos políticos que tentavam controlar as disputas locais, as fraudes continuavam frequentes ${ }^{29}$.

Além das disputas entre Exército e Marinha e entre republicanos sulistas e do sudeste, o início do período republicano contou, também, com a oposição das chamadas "Guardas Negras" - composta de capoeiras, ex-capoeiras e outros insurgentes -, as quais possuíam inclinação monarquista. Não pretendo me debruçar sobre as razões pelas quais negros organizados defendiam o Império, embora não pareça estranho quando se sabe que a República era construída pelas mãos de ex-proprietários de escravos que pretendiam aquilatar ganhos indenizatórios pela perda de suas propriedades. No Recife, era essa a configuração do Partido Republicano. Esses integrantes das guardas negras foram especialmente perseguidos e presos por autoridades policiais, conforme relatarei no quarto capítulo.

Para além das instabilidades políticas, as cidades mudavam substancialmente no início da Primeira República, reconfigurando as demandas sobre ordem pública. A ideia de uma onda negra continuava a ser fonte de temor, mas agora representada na imagem de exescravos que não mais eram vigiados pelos seus proprietários e capatazes, ficando sujeitos ao jugo policial, mas também a regras de regulamentação do trabalho doméstico, do trabalho

\footnotetext{
${ }^{28}$ SCHWACZ, Lilia M.; STARLING, Heloísa M. Brasil: uma biografia. São Paulo: Companhia das Letras, 2015, p. 321.

${ }^{29}$ SCHWACZ, Lilia M.; STARLING, Heloísa M. Brasil: uma biografia. São Paulo: Companhia das Letras, 2015, p. 322.
} 
informal e de vendedores nas ruas, de reorganização dos centros de comércio, de higienização das cidades, de ordenação das moradias e bairros.

As elites intelectuais e políticas brasileiras viviam o sonho civilizatório, registrado na nossa bandeira com as palavras "ordem e progresso" e, nos documentos oficiais, observei que as falas de representantes de governo e de policiais eram sempre orientadas a um projeto premente de limpar e ordenar as cidades, de adotar um padrão de sexualidade adequado, de expurgar os elementos danosos e de disciplinar a infância e a adolescência que ocupavam as ruas.

Concomitante a isso, o saber científico racista reforçava - agora com pretensões de neutralidade típica do discurso das ciências na modernidade - a inferioridade dos homens e mulheres negros, atrelados naturalmente ao alcoolismo, à vadiagem, à promiscuidade sexual e à desordem familiar. Para muitos, o atraso brasileiro era relacionado ao elemento negro, que deveria ser expulso ou, aos poucos, neutralizado, constituindo as políticas estatais de apoio e incentivo à imigração europeia uma das expressões dessa visão.

Interessantes trabalhos sobre espaço urbano e circulação de corpos negros no período têm sido realizados, buscando compreender os mecanismos de disciplinarização tocados pelo estado no governo das populações ${ }^{30}$. A gramática foucaultiana sobre biopoder e racismo ${ }^{31}$ acaba por aparecer como referencial teórico útil, na medida em que o autor localiza os mecanismos de racismo de Estado também na gestão das cidades e no controle sanitário de pragas, doenças, na limitação ao nascimento e nas táticas de eliminação dos elementos daninhos - os sujeitos classificados pelas teoriais racialistas da época como inferiores e degeneradores. Essas táticas distribuem-se desde o controle policial dos territórios e expulsão dessa parte da população de determinados espaços até os dispositivos de morte, como foram os campos de concentração na Alemanha nazista.

Era essa, enfim, a imagem da sociedade brasileira na passagem do século XIX para o século XX: a de uma busca pelo progresso assimilado aos países europeus mais influentes como a França e a Inglaterra. Era a República em construção, em plena ascensão. Uma República não mais escravocrata, que anunciava a igualdade de direitos, mas que, em termos de organização de suas estruturas de poder, de distribuição de bens e de direitos, privilegiava homens brancos.

\footnotetext{
${ }^{30}$ Conferir: PORTELLA, Bruna. Embranquecer a cidade negra: gestão do trabalho de rua em Salvador no início do século XX. Dissertação de mestrado. Programa de Pós-Graduação em Direito, UnB, 2017.

31 “A biopolítica lida com a população, e a população como problema político, como problema a um só tempo científico e político, como problema biológico e como problema de poder, acho que aparece nesse momento". FOUCAULT, Michel. Em defesa da sociedade. São Paulo: Martins Fontes, 2005, p. 293.
} 
As cidades, portanto, não seriam para todos, embora agora fosse preciso pensar e construir novos mecanismos de interdição à circulação, compatíveis com o fim da escravidão e o novo regime político. Isso não seria difícil com o Código Penal de 1890, que previa a criminalização de condutas semelhantes às constantes no Código Criminal do Império, de 1830, e nas posturas municipais criadas ao longo de quase todo o período Imperial (vadiagem, embriaguez etc) e, sobretudo, com uma parca regulamentação da atividade policial, que permitiu a perpetuação de uma polícia à Vidigal, "o rei absoluto, o árbitro supremo de tudo o que dizia respeito a esse ramo da administração", como ilustrado em Memórias de um sargento de Milícias.

Neste sentido, é bastante simbólico que o primeiro chefe de polícia do Distrito Federal, na era republicana, João Batista Sampaio Ferraz, tenha se tornado conhecido por se tornar um 'caça a capoeiras', tendo chegado a registrar a prisão de 111 deles em uma única semana, entre 12 e 18 de dezembro de $1889^{32}$. Essas prisões eram feitas sem qualquer controle judicial e ficavam ao puro arbítrio da polícia e de seu chefe, tendência que observei na cidade do Recife entre 1915 e 1930, portanto, muitos anos depois.

Nas ruas da capital pernambucana, vários Vidigais pareciam manter seus ofícios prendendo cerca de dez pessoas por dia sem ordem judicial, detendo indivíduos para averiguação, mapeando e vigiando organizações operárias, varejando casas particulares de prostitutas, fazendo acordos e negociações sobre quem prender ou não prender, quem soltar ou não soltar, que atividades tolerar e quais reprimir. Parecia persistir, enfim, a polícia soberana que atuava ao longo do Império.

Afinal, o que entender por "soberania policial"? Definir é escolher alguns elementos marcantes e deixar de lado outros que julgamos menos relevantes na caracterização de um fenômeno social. Ao falar na polícia republicana como uma organização soberana, por exemplo, escolhi ressaltar um de seus aspectos, qual seja, a liberdade de escolhas e decisão com a qual desenvolviam suas atividades, deixando de lado uma caracterização corrente que a vê como uma força dependente das vontades políticas locais, quando, sobretudo no início da República, os governos estaduais tinham bastante independência, inclusive para legislarem sobre processo penal $^{33}$ e, consequentemente, para determinar as atribuição de poderes policiais.

\footnotetext{
32 BRETAS, Marcos Luiz. A queda do império da navalha e da rasteira (a República e os capoeiras). Estudos Afro-Asiáticos, n. 20, junho, 1991, p. 250.

33 A Constituição de 1891 estabelecia competir privativamente ao Congresso Nacional "Artigo 34, n. 23: Legislar sobre o direito civil, commercial e criminal da Republica e o processual da justiça federal". Portanto, o direito processual da justiça estadual ficava a cargo de cada uma dessas unidades da federação.
} 
Isso não quer dizer que chefes de polícia, delegados e subdelegados escolhidos e exonerados livremente por governadores não estivessem sujeitos a pressões superiores ou que praças, guardas civis e policiais militares não fossem, por vezes, obrigados a cumprir ordens emanadas direta ou indiretamente daqueles mesmos governadores, quando não das autoridades da polícia civil. Essa dependência é inegável e é um dos interessantes aspectos sobre a construção das polícias.

Porém, ao analisar as práticas dessas polícias entre 1915 e 1930, mesmo o fazendo com base em fontes produzidas por elas própria, não pude deixar de verificar que, entre a ordem superior e a execução dela, havia um grande hiato. No cotidiano, policiais de todos os níveis hierárquicos pareciam estar autorizados a deixar a ordem superior de lado e fazerem outra coisa. Não soa estranha a frase de um guarda civil, dita, em 1916, a um policial militar: "procedo como quiser nas horas de serviço!"; como também não é de causar espécie a sistemática prática de delegados e subdelegados de prender indivíduos pelo tempo que julgavam necessário, sem judicilizarem a questão e sem serem questionados a tanto.

Desse modo, tratar a polícia como mero reflexo das vontades dos governos ou elites locais - o que não é uma inverdade - é perder de vista muitos acontecimentos e atividades que compreendiam o cenário cotidiano dessa organização. Digo que não é uma inverdade porque não é possível afastar a hipótese de que a polícia perseguia e prendia preferencialmente pretos, pobres e subversivos morais ou políticos, a imagem da escória e do Outro, quando se toma como referência a elite branca que ocupava o poder em Pernambuco. Há, portanto, boas evidências de que, no início do novo regime, "os grupos dominantes aproveitaram a sua aurora para atualizar as suas formas repressivas com relação aos segmentos dominados da sociedade" 34 .

Porém, gostaria de analisar mais do que isso, sem, por certo, prescindir dessas observações. Insisto no conceito de soberania policial por entender que é o que melhor retrata, apreende e reflete as narrativas que encontrei nos arquivos policiais. Tentarei, então, delimitálo.

\subsection{ENSAIANDO O CONCEITO DE SOBERANIA POLICIAL}

A definição de "soberania" apresenta muito meandros. Porém, desde a concepção estampada por Jean Bodin em Os seis livros da República, ela remete ao poder do Estado de

\footnotetext{
${ }^{34}$ MATOS, Ilmar Rohloff de; CARVALHO, Maria Alice R. de. A polícia e a força policial no Rio de Janeiro. Estudo das características histórico-sociais das instituições policiais brasileiras, militares e paramilitares, de suas origens até 1930. Rio de Janeiro: PUC, 1981, p. 180.
} 
comandar de forma absoluta. Neste sentido, “o Estado é a sede da soberania potência, o ponto

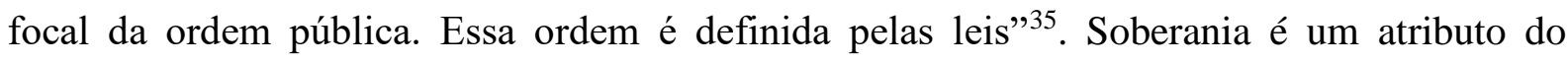
Estado, que a exerce sobre indivíduos e com fundamento no direito.

Essa concepção clássica é um bom ponto de partida, mas apresenta um problema: supor que soberania emana apenas de um grande centro de poder, os chefes de governo ou de Estado, e que indivíduos localizados em estratos inferiores de uma organização, como policiais militares, por exemplo, presentes cotidianamente nas ruas, funcionem apenas como mandatários, não possuindo liberdade para realizar escolhas e empreender ações conforme seus próprios juízos de conveniência e valor. Não é bem assim que a banda toca e tampouco como tocava no período estudado.

Michel Foucault, em sua analítica do poder, propõe superar essa noção clássica de soberania e apresenta um contributo relevante para este trabalho. Para ele, pensar o poder não é apenas focar na sua fonte, o Estado, do qual ele emana, e nas estratégias utilizadas para adquirir obediência dos súditos. Sem dúvidas essa é uma questão fundacional na Teoria Política - "porque tantos servem a um só?", como se perguntaria Étienne de la Boétie -, mas a contribuição foucaultiana se dá no sentido de ilustrar como nas relações sociais em todos os níveis desenvolvem-se mecanismos de dominação, como entre alunos e professores, pacientes e médicos, pais e filhos etc ${ }^{36}$. Inclusive, o grande objetivo de seus escritos reunidos nessa segunda fase de sua obra é justamente compreender como funcionam os dispositivos de poder a nível infinitesimal e como eles são constituidores de discursos de verdade e de técnicas de normalização, de sujeição ${ }^{37}$.

A concepção foucaultiana apresenta limites sérios à compreensão dos mecanismos de controle policial no Brasil. Porém, sem dúvidas, para pensar em soberania policial é preciso investir nas microinterações de dominação, permeadas por questões locais, históricas e culturais que somente podem ser interpretadas a partir de um olhar mais próximo e menos baseado na simples estrutura de poder como repressão estatal.

Lógico que não é possível deixar de lado o Estado e o direito quando se fala em polícia, afinal, ela é a organização pública dotada do uso legítimo da força e que busca

\footnotetext{
${ }^{35}$ CHÂTELET, François; DUHAMEL, Olivier; PISIER-KOUCHNER, Evelyne. História das ideias políticas. Rio de Janeiro: Zahar, 2009, p. 44.

${ }^{36}$ FOUCAULT, Michel. Em defesa da sociedade. São Paulo: Martins Fontes, 2005, p. 51-52.

${ }^{37}$ A anatomia política foucaultiana procura descrever o poder, "dissolve a grande unidade do poder, a sua identificação demasiado simples com o Estado e os seus aparelhos: ao poder, ela opõe as relações de poder e a pluralidade dos 'micropoderes' que elas constituem. A anatomia política faz aparecer o poder como produtor; obriga a conceber as relações de poder não como relações de repressão, de interdição ou de proibição, mas, muito mais profundamente, como relações de produção". EWALD, François. Foucault, a norma e o direito. 2 ed. Lisboa: Vega, 2000, p. 30.
} 
produzir "alternativas de obediência com consentimento social, sob o Império da Lei"38. São seus agentes convocados em qualquer situação de desrespeito à lei e à ordem pública, devendo fazê-lo em nome do interesse público e não de forma tirânica ou para satisfazer demandas particulares.

Porém, é próprio à atividade policial a discricionariedade em termos do que fazer, de como agir e de quando fazê-lo em situação críticas. Por conseguinte, uma parte da "ação policial está sujeita à apreciação política, social ou judicial apenas a posteriori" ${ }^{39}$.

Além disso, a polícia "na rua" está, invariavelmente, além e aquém dos rígidos limites impostos por leis, transitando, com frequência, no ambiente da informalidade ou da improvisação, momento em que, passar da discricionariedade à arbitrariedade se torna um simples ato de vontade. Portanto, nos mecanismos "infinitesimais" de poder, a soberania policial se expressa muitas vezes não através da aplicação irrefreável da lei, mas na possibilidade de se realizar negociações, acordos e suspensão da própria lei, e, neste cenário, “o espaço público, a rua - enquanto lócus por excelência da práxis policial - transforma-se no ‘território' dos policiais"40, como lembra Misael Santos. Isso é tão inevitável quanto problemático.

Nesse diapasão, soberania policial não implica apenas uma polícia que é unicamente a representação máxima e principal da soberania estatal, porque, por vezes, dinâmicas locais, em bairros e em comunidades, adquirem vida própria.

A palavra "soberania", portanto, liga-se, aqui, mais ao atributo de comandar do que ao locus em que esse poder se localiza, o Estado, mesmo que todo agente policial seja um representante formal do Estado, afinal nem sempre ele atua em cumprimento direto desse poder, razão pela qual desvinculei soberania policial de simples expressão da soberania estatal.

Há também outro aspecto que reforça essa distinção: se as forças policiais fossem simples expressão da soberania estatal e da vontade, portanto, de um governante, não se verificaria conflitos e divergência entre elas e esse quadro é o oposto do que foi verificado na pesquisa. Policiais civis, militares, guardas civis e membros das forças armadas disputavam, entre si, poder nas ruas e chegavam a vivenciar conflitos armados que, no limite, levaram à morte de alguns deles.

\footnotetext{
${ }^{38}$ MUNIZ, Jacqueline; PROENÇA JR., Domício. Mandato policial. AZEVEDO, Rodrigo G. de; LIMA, Renato; RATTON, José Luiz (orgs). Crime, polícia e justiça no Brasil. São Paulo: Editora Contexto, 2014, p. 494.

${ }^{39}$ MUNIZ, Jacqueline; PROENÇA JR., Domício. Mandato policial. AZEVEDO, Rodrigo G. de; LIMA, Renato; RATTON, José Luiz (orgs). Crime, polícia e justiça no Brasil. São Paulo: Editora Contexto, 2014, p. 496.

${ }^{40}$ SANTOS, Misael. Os usos da força física por Policiais Militares: descrevendo práticas, entendendo sentidos. Dissertação de Mestrado. Programa de Pós-Graduação em Ciências Sociais, UFBA, 2014, p. 65.
} 
Como se vê, estou o tempo todo pensando o conceito a partir dos dados encontrados na pesquisa e ligado à realidade da atuação policial no Recife do início do século XX. Não é, entretanto, uma descrição de simples idiossincrasias, porque, por vezes, padrões de funcionamento das forças policiais observados por mim ao longo da investigação aparecem em trabalhos sobre a polícia no início do período republicano no Distrito Federal, em São Paulo e outros estados.

Feitas essas primeiras ressalvas, tentarei desenvolver o conceito em exame, cujas expressões e formas de funcionamento serão expostas com pormenor ao longo do texto. Falo em soberania policial quando a organização, embora tenha suas atividades e carreiras regulamentadas em lei, permite a seus agentes, dos mais diversos níveis hierárquicos, escolher atuar cotidianamente conforme códigos extralegais lícitos ou ilícitos, sem que, em razão disso, estejam sistematicamente sujeitos a controles interno ou externo. Essa soberania é menos ou mais intensa quando esses espaços de liberdade se restringem ou se ampliam.

De modo mais sistemático, aponto as seguintes características: a) regulamentação em lei da organização e de parte das atividades desempenhadas por seus agentes; b) amplo espaço para escolhas em situação não previstas ou vagamente regulamentadas pelo direito, escolhas estas que podem ser conforme ou não ao direito e c) suspensão da ordem jurídica sem que haja, em função disso, responsabilização sistemática.

A primeira característica de uma polícia soberana é estar inserida em e disciplinada por um conjunto de normas jurídicas, o que representa o controle prévio dessa atividade. Nenhuma força policial pode atuar totalmente fora da lei, porque, do contrário, se confundiria com uma organização verdadeiramente paralegal, como grupos de extermínio. Sendo assim, ela possui regulamentos e deve obediência a legislações das mais diversas matérias, notadamente a penal e a processual penal, devendo revestir seus atos de um aspecto de legalidade.

A segunda característica advém do fato de que nem tudo o que as polícias fazem diariamente está dentro desse quadro normativo previamente construído. Primeiramente porque, como pontuado, há situações imprevisíveis enfrentadas pelas forças policiais, reservando-se aos seus agentes alguma margem de inovação. Por outro lado, há um fator que favorece muito a ampliação desses espaços de escolha, que é a ausência de previsão legal sobre situações críticas cotidianas como a abordagem policial, o uso da força, as incursões em domicílio etc. Até hoje as legislações pouco ou nada discorrem sobre esses aspectos, o que era também a realidade no início do século XX. Assim, está-se diante da segunda característica da 
soberania policial, traduzida em um "fazer o que quiser", "como quiser" e "quando quiser", porque não há um protocolo de atuação a seguir.

O vazio normativo dá margem a escolhas pessoais dos agentes, muitas vezes baseadas na cultura da organização, na experiência dos policiais ou mesmo em interesses particulares.

Uma terceira característica é a naturalização do recurso à ilegalidade. Nestes casos, policiais - dos mais diversos extratos, repita-se - suspendem expressamente a norma e promovem investigações sob tortura, maus tratos ou outras formas de tratamento degradante, vigiam vidas e intimidades sem autorização judicial, violam o domicílio alheio. Talvez, aqui, esteja-se diante da expressão máxima dessa soberania, que permite aos agentes policiais negar a lei e escolherem seus próprios métodos para alcançar finalidades da organização ou estranhas a ela.

No primeiro caso, há a situação da suspensão da lei a fim de elucidar um delito, por exemplo. É muito comum a justificativa de atos ilícitos em nome da eficiência, conflito que, até hoje, permeia as discussões sobre uso de provas ilícitas no processo penal, quando isso vem a ser descoberto. A tortura, por exemplo, é comumente justificada como único método capaz de conduzir ao culpado.

Marcelo Barros, em uma investigação com policiais civis de hoje, verificou que muitos escrivães e delegados que praticam torturas ou "tiram serviço", como preferem nomear, o faziam não por serem sádicos ou gostarem de bater, mas por entenderem que, sem isso, não alcançam os níveis de cobrança por resolutividade ${ }^{41}$. Por certo, esse poderia ser também um raciocínio para a época examinada nesse trabalho.

A atuação ilegal da polícia também poderia perquirir vantagens pessoais indevidas, fugindo aos objetivos da organização.

Esse elemento relativo às atuações ilegais, truculentas, preconceituosas e corruptas não são de fácil apreensão, sobretudo quando se trabalha com documentos produzidos pela própria polícia, como no meu caso. Assim, outras fontes precisariam ser investigadas como notícias de jornal, relatos pessoais, a literatura, manifestos políticos etc.

Ainda assim, cheguei a verificar uma série de práticas ilegais que, de tão arraigadas, eram descritas nos relatórios sem maiores constrangimentos. A primeira e mais estonteante delas é o caso das prisões correcionais de ébrios, vadios, menores abandonados, prostitutas e outros, realizadas por delegados e subdelegados de polícia mesmo sem qualquer previsão

\footnotetext{
${ }^{41}$ BARROS, Marcelo. Polícia e tortura no Brasil: conhecendo a caixa das maçãs podres. Curitiba: Appris, 2015, p. 100.
} 
legal para tanto. Como era uma prática amplamente aceita, chegavam a ser registradas nos livros policiais e mesmo nas estatísticas oficiais.

Também foi possível detectar outros casos de atuação contra a lei quando o imbróglio envolvia mais de uma força policial, como a militar e a civil. Aqui, policiais civis precisavam justificar suas condutas e o faziam imputando as arbitrariedades eventualmente reclamadas por cidadãos ou na mídia às outras forças e vice-versa. Alguns casos de espancamento que eu verifiquei nas narrativas policiais, por exemplo, foram relatados por delegados ou subdelegados, que, justificando-se à Chefia de Polícia, diziam ter sido responsabilidade dos policiais militares ou dos guardas civis. Esse acabava sendo um dos efeitos positivos da existência de mais de uma organização policial: uma servir de controle à outra ${ }^{42}$.

Enfim, ser "donos da rua" implica ocupar o espaço da força oficial e legítima do Estado e, ao mesmo tempo, poder escolher o que fazer, materializando-se essas decisões em atos legais ou ilegais.

Que fatores tornaram possível o surgimento de corpos policiais que atuavam com tanta independência? As respostas foram também buscadas no trabalho de campo, embora possam ser relacionadas a debates atuais sobre polícia. Procurarei destrincha-las ao longo do trabalho, quando abordarei quatro condições que fortaleciam esse comportamento soberano da polícia nas ruas.

Primeiramente, o grupo social frequentemente abordado e interpelado em ações policiais. Pelos registros das prisões apresentados pelas chefias de polícia pernambucana entre 1915 e 1930, fica evidente que ela exercia esse poder soberano sobre as camadas pobres e negras da sociedade, a quem a cidadania era total ou parcialmente negada. Quando essa clientela se alterava, era possível verificar reações inflamadas por parte da própria sociedade, como no caso de perseguição a estudantes envolvidos em grupos políticos ou anarquistas e mesmo em situações mais comuns, como foi o caso de uma operação tida como truculenta contra sete portugueses que residiam em uma casa no centro do Recife. No caso, a proprietária do imóvel teria ido até a Delegacia pedir ajuda no despejo dos inquilinos porque eles teriam deixado de pagar o aluguel. A polícia respondeu à demanda da proprietária, mas, aparentemente, o fez de modo tão abusivo que até a Embaixada de Portugal se envolveu, pedindo esclarecimentos e providências à Chefia de Polícia.

\footnotetext{
${ }^{42}$ Hoje a sociologia criminal aponta a existência de mais de uma polícia como um fator de controle externo formal da corporal policial. Ver: CANO, Ignácio. Controle de polícia no Brasil.. Haia: Altus, 2005. Disponível em: <www.soudapaz.org/upload/pdf/textocanoppc.pdf>. Acesso em 11 ago 2017.
} 
Assim, nem todos os moradores da cidade do Recife corriam o risco de serem abordados ou presos arbitrariamente e de terem suas casas vasculhadas sem prévia determinação judicial. Esse aspecto me parecia óbvio porque eu estava acostumada às leituras sobre seletividade do sistema penal. Depois, passei a ler essas manifestações como expressões do racismo e uma de suas facetas: atribuir cidadania de forma totalmente assimétrica aos membros de uma sociedade.

Um segundo fator a favorecer o fenômeno em exame era a legislação processual penal. Ao longo do século XIX e início do século XX, ela atribuiu a delegados e chefes de polícia poderes muito amplos para a manutenção da "ordem pública", tendo eles chegado até mesmo a poder processar e julgar vagabundos, ébrios, desordeiros etc. Entre 1852 e 1871 eles foram, portanto, policiais-juízes para um determinado setor da população, o que, por certo, não se desaprende com o simples advento da proibição ou da República.

Além dessas disposições claramente permissivas, falarei sobre um terceiro fator, correlato a este último, que é a omissão da lei no trato de determinadas matérias do mandato policial e o silêncio sobre a atividade policial na doutrina processual penal. Ao que me pareceu, juristas que, no final do século XIX e início do século XX, passaram pelos bancos das faculdades de direito, como a Faculdade de Direito do Recife, não ouviram sequer falar de uma polícia que, nas ruas, controlava a circulação de determinadas pessoas sem muito critério ou mesmo que as prendia como queria e sem repassar essas informações à justiça. Esses juristas ocupariam, depois, os cargos mais privilegiados das forças policiais e se tornariam chefes de polícia e delegados.

Como disse, polícias soberanas surgem em ambientes em que são frágeis os controles prévio e posterior de seus atos. Cumpre ressaltar que, ao falar em falta de controle da atividade policial, é preciso evitar os anacronismos. Certamente, os debates sobre a necessidade da realização de controle social ou institucional a nível externo ou interno das polícias se intensificaram nas democracias mais maduras e, no Brasil, somente após a ditadura militar, quando parece que, finalmente, esse dado se tornou relevante.

Por outro lado, também é verdade que no início do século $\mathrm{XX}$ - e já desde o século anterior -, as dogmáticas penal e processual penal brasileiras estavam plenamente cientes da necessidade de observância de princípios constitucionais e de garantias como a ampla defesa, o contraditório, a proibição de prisões sem ordem judicial, o habeas corpus e a vedação à tortura como instrumentos de controle do Estado punitivo.

$\mathrm{Na}$ abertura de seu livro "Apontamentos sobre o processo criminal brazileiro", José Antonio Pimenta Bueno adverte que a lei processual penal era a segurança que teria o cidadão 
frente ao arbítrio. Como um bom liberal, antepunha o passado bárbaro do descontrole às recentes inovações em termos de direitos:

Felizmente já não vigora o nosso antigo processo da Ordenação do livro $5^{\circ}$, o poder despótico dos ministros, as penas arbitrárias, os tormentos empregados para forçar uma confissão, os trâmites secretos, a impossibilidade da defesa, o mistério e o arbítrio da tyrania! O coração virgem e as nobres paixões da mocidade brazileira já não irão desmoralizar-se e degradar-se com esses estudos e ideias bárbaras, com essas sensações repulsivas ${ }^{43}$.

Ao mesmo tempo, alguns setores do campo jurídico estavam plenamente cientes de abordagens truculentas promovidas pelas polícias contra certas atividades como a prostituição e a vadiagem. Encontrei em várias obras da época notas sobre a desnecessidade desse tipo de atitude, a exemplo de Evaristo de Moraes e de José Burle de Figueiredo. Moraes, em "Ensaios de patologia social", opunha-se à intervenção policial sobre a prostituição, defendendo a liberdade individual e a necessidade de as questões relativas à saúde e doenças venéreas serem tratadas no campo médico e não policial. Ele "deixava claro sua irritação com o aumento de poder que a policia adquiria sobre a sociedade" 44 . O mesmo pode ser dito em relação a Figueiredo, para quem a repressão à vadiagem demandava intervenção educativa, laboral, disciplinadora e não simples repressão policial ${ }^{45}$.

Porém, tais preocupações não pareciam reverberar na criação de mecanismos sistemáticos de controle e a polícia seguiu agindo dessa forma século $\mathrm{XX}$ adentro, sofrendo pouco constrangimento. Entretanto, evidentemente que não imune a críticas. Na virada para aquele século, é possível verificar um grande esforço dos principais chefes de polícia do Brasil, sobretudo os do Distrito Federal, para melhorar a imagem da polícia, que perpassaria não apenas por demonstrar os esforços pela modernização, precisão e cientificidade de suas investigações e demais atos, como também de encontrar no campo do direito os discursos autorizadores de sua autonomia enquanto organização e da necessidade de se pensar uma ampliação na concepção sobre o poder de polícia.

Não é à toa que, em 1917, Aurelino Leal, chefe de polícia do Distrito Federal, convocou uma Conferência Judiciária-Policial, reunindo juízes, ministros do Supremo Tribunal Federal e chefes de polícia, a fim de afinarem seus discursos. Na conferência,

\footnotetext{
${ }^{43}$ BUENO, José Antonio Pimenta. Apontamentos sobre o processo criminal brazileiro. 3 ed. Rio de Janeiro: H Garnier, Livreiro Editor, 1902, p. XI.

${ }^{44}$ RAGO, Margareth. Os prazeres da noite: prostituição e códigos da sexualidade feminina em São Paulo (18901930). São Paulo: Paz e Terra, 2008, p. 154.

${ }^{45}$ FIGUEIREDO, José Burle de. A contravenção de vadiagem. Rio de Janeiro: Jacintho Ribeiro dos Santos Editor, 1924.
} 
estavam em debate as principais dificuldades para a segurança pública no Brasil e o que a polícia e o judiciário poderiam, juntos, fazer. Não faltaram, ali, discursos e falas como a do então ministro do STF, Augusto O. Viveiros de Castro:

Como estamos em família, é melhor confessarmos lisamente as nossas culpas: ficará bem garantida a ordem pública, se houver completa harmonia de vistas entre os magistrados e as autoridades policiaes, deixando uns de serem tao formalistas, tão apegados á letra da lei, considerando os outros os seus cargos como uma verdadeira profissão e não como simples achega. O habeas corpus é o palladium das liberdades publicas; não pode ser manta para abrigar $\operatorname{criminosos}^{46}$.

Foi assim que parte do campo jurídico emprestou legitimidade à soberania policial: silenciando sobre ela ou a autorizando expressamente. Esse aspecto eu me referirei como legitimação da soberania policial por parte do campo jurídico, argumento desenvolvido no capítulo 3.

Por fim, o quarto fator que favorecia esse padrão de atuação policial era a legitimidade que a ela emprestava a própria sociedade. Por mais que estivessem em xeque cotidianamente, as agências policiais não atuavam, no período estudado e, creio que hoje também não o faça, completamente apartada das expectativas que os cidadãos lançavam sobre ela. No início do período republicano, a polícia era alvo de inúmeras críticas, instituição "odiada", como lembravam alguns chefes de polícia em seus relatórios, mas era, ao mesmo tempo, cotidianamente procurada para resolver as mais diversas pendengas, sobretudo pelas pessoas mais pobres. Eram aos chefes de polícia e aos delegados e subdelegados a quem frequentemente cidadãos recorriam procurando ajudas que iam além de questões criminais e perpassava a cobrança de dívidas, o resguardo da honra familiar etc.

É importante, neste ponto, lembrar que as bases policiais - praças, soldados e agentes - eram recrutadas dos mesmos bairros e comunidades para onde voltariam, primordialmente para vigiar, gerando uma valorização da "experiência de rua" - cada bairro parece ser conhecido na palma da mão por determinados policiais -, conhecimento este que acaba por se apresentar como racionalizador dos processos de suspeição e abordagem ${ }^{47}$.

\footnotetext{
${ }^{46}$ CASTRO, Augusto Olympio Viveiros de. These VI. Seção II. Annaes da Conferência Judiciária-Policial de 1917. Rio de Janeiro: Imprensa Nacional, 1918, p. 266.

47 “A "experiência de rua”, seja adquirida de forma direta ou por meio da troca de impressões entre pares, aporta repertórios e calibra o olhar ao testar, muitas vezes na prática, no 'erro e acerto', a eficácia operativa do 'faro', como um sistema de valores, na produção - dentre outras tantas coisas - de proteção, antecipação e controle de condutas". ALBERNAZ, Elizabete. "Faro Policial": um estudo de caso acerca dos critérios de construção e operação de padrões de suspeição e seletividade na ação policial. $39^{\circ}$ Encontro Anual da Anpocs, Caxambu, 2015 , p. 4.
} 
Por outro lado, a aproximação desses policiais com a comunidade pode também vir a gerar vínculos de confiança, fazendo a polícia ser procurada em momentos de dificuldade. $\mathrm{O}$ acesso à justiça, portanto, era mediado pelas forças policiais, em uma sociedade em que o poder judiciário era composto por homens brancos da elite e na qual aproximação com a comunidade não era ainda uma questão.

Dito isto, exporei no próximo ponto alguns marcos teóricos que auxiliaram na leitura do meu campo e nas elaborações conceituais.

\subsection{ENSAIANDO MARCOS TEÓRICOS}

Em quatro anos de leituras e de encontros com muitas lentes interpretativas e, ao mesmo tempo, deparando-me com dados empíricos coletados em um arquivo histórico, tive a sensação de que nenhuma teoria seria capaz de dar conta de todos os aspectos do fenômeno observado e, ao mesmo tempo, de que todas elas são, em certa medida, relevantes no processo de identificação e de compreensão do problema, porque, aqui e acolá, lançam luz sobre elementos diversos de outra teoria e, assim, vão cobrindo pontos-cegos e abrindo outros.

Chegar ao meu tema de pesquisa já foi, como disse, uma tarefa de deixar os dados empíricos dialogarem com as teorias, refutando-as ou as confirmando. A relação teoria-prática foi, portanto, necessariamente circular.

Optei por não desenvolver um capítulo apenas para meus marcos teóricos, posto que essas contribuições serão expostas ao longo de todo o trabalho, à medida que as temáticas forem surgindo. Essa seria a forma mais coerente de tratar os marcos teóricos que não foram, para mim, confirmados ou infirmados, mas serviram como apoio para ler fenômenos e tentar criar sobre eles novas teorizações. Abaixo, descrevo apenas o núcleo de cada uma dessas escolas ou conjunto de pensadores que foram por mim utilizados, apontando para as suas possíveis conexões e limites.

\subsubsection{A criminologia crítica latinoamericana}

Primeiramente, comecei a enfrentar meu objeto de tese a partir de leituras da criminologia crítica brasileira e latino-americana. As provocações de Eugenio Raul Zaffaroni a respeito da necessidade de um realismo marginal, de uma criminologia desenvolvida a partir da realidade das sociedades latinoamericanas, marcadas pelo processo colonial, pelos genocídios indígena e negro e por séculos de um sistema escravocrata me conduziram a privilegiar o material produzido no continente. 
As perspectivas criminológico-críticas na América Latina, embora não possam ser inscritas em uma única tradição teórica, estiveram fortemente ligadas ao pensamento sobre o controle do crime desenvolvido em países europeus, sobretudo a Itália, e nos Estados Unidos. Três grandes teorias estiveram, assim, fazendo parte, desde a década de 1970, desses estudos: o materialismo histórico, as ideias sobre sociedade disciplinar e biopoder foucaltianas e a Teoria do Etiquetamento.

A primeira dessas tendências, inscrita nas obras de autores como Rusche e Kirchheimer, Massimo Pavarini, Dario Melossi e Alessandro Baratta estabelece grandes narrativas sobre o sistema punitivo e o desenvolvimento das sociedades capitalistas ${ }^{48}$. De um modo geral, a penalidade é desvinculada de seus efeitos de controle da criminalidade e pensada como expressão das necessidades do sistema capitalista. As agências estatais responsáveis pelo controle do crime funcionariam: a) para administrar a escassez ou abundância de mão-de-obra, preparando-as para o trabalho industrial e b) para gerir a miséria e os consumidores falhos - aqueles indivíduos não absorvidos pelo sistema econômico (ébrios, mendigos, indigentes, usuários de drogas etc).

Nesse contexto, o sistema penal protegeria preferencialmente bens jurídicos ligados à burguesia, como a propriedade e a estabilidade do sistema econômico, mantendo a desigualdade estrutural das sociedades. Para essa tradição, “o modo como o sistema de justiça criminal intervém sobre este limitado setor da 'violência' construído através do conceito de criminalidade, é estruturalmente seletivo" 49 , deixando de lado, por exemplo, uma realidade vivida por boa parte dos países latinoamericanos nas décadas de 1960, 1970 e 1980: o terrorismo de Estado.

No Brasil, essas leituras estiveram presentes nas obras dos primeiros representantes da criminologia crítica, como Vera Regina Pereira de Andrade, Juarez Cirino dos Santos e Nilo Batista. Eles apresentam importantes releituras sobre a dogmática penal e seu comprometimento com os interesses do capital e da burguesia, verificável na teoria do crime e sua incapacidade de lidar com a criminalidade econômica e societária, na teoria da pena e sua predileção pelo encarceramento como proposta político criminal e nas teorias dos bens jurídicos e as construções dos crimes em espécie, quando é possível perceber um maior

\footnotetext{
${ }^{48}$ São três as obras fundamentais que desses autores que desenvolvem a tese em apreço: RUSCHE, Georg; KIRCHHEIMER, Otto. Punição e estrutura social. 2 ed. Rio de Janeiro: Revan, 2004; MELOSSI, Dario; PAVARINI, Maximo. Cárcere e fábrica: as origens do sistema penitenciário (Século XVI-XIX) . 2 ed. Rio de Janeiro: Revan, 2010; BARATTA, Alessandro: Criminologia Crítica e Crítica do Direito Penal: Introdução à Sociologia do Direito Penal. 3 ed. Rio de Janeiro: Editora Revan: Insitutito Carioca de criminologia, 2002.

49 BARATTA, Alessandro. Direitos humanos: entre a violência estrutural e a violência penal. Fascículos de Ciências Penais. Ano 6, v. 6, n.2, p. 44-63, 1993, p. 49.
} 
investimento sobre a criminalidade contra o patrimônio praticada por pessoas mais pobres e uma inoperância ou conivência frente àquela promovida pelos setores mais ricos e ligados ao capital, como os delitos contra a ordem tributária, a corrupção e o meio ambiente, dentre outros.

Na América Latina, essa perspectiva estava estampada nas obras de Rosa Del Olmo, Lola Aniyar de Castro, Roberto Bergalli, dentre outros. Lola ainda coordenou o Grupo Latino-Americano de Criminologia Comparada ${ }^{50}$ e o Grupo de Criminólogos Críticos Americanos, cujos integrantes partiam da mesma base teórica e epistemológica, chegando a conclusões muito semelhantes aos autores que lhes serviram de base.

Como destacava Lola, em seu "Criminologia da Libertação", os sistemas penais logravam êxito em "reproduzir o sistema de classes e deixar a classe hegemônica de mãos livres para realizar seus objetivos do senso comum, as quais, ao separar as classes de delinquentes das classes não delinquentes, consolidam a estratificação" ${ }^{51}$. Ao mesmo tempo, entendiam esses autores que a criminologia positivista, desenvolvida no continente entre os séculos XIX e XX, comprometeu-se em identificar nos indivíduos, sobretudo negros e indígenas, as causas para o delito, compreendendo-as como um defeito moral, ao invés de investir nas desigualdades do próprio sistema capitalista como um gerador de miséria ${ }^{52}$.

Também a perspectiva foucaultiana sobre a prisão e outros dispositivos disciplinares corrobora com essa tese central, quando menciona a vitória do projeto prisional na modernidade como uma consequência do desenvolvimento das sociedades de capitalismo industrial. A perspectiva do autor não é marxista e em muitos aspectos difere da leitura materialista histórica sobre o poder, mormente quando pretende destacar outras dimensões das relações de opressão, vivenciadas nas microinterações sociais, como já destacado acima. Porém, neste ponto em especial, sobre a vitória da prisão como mecanismo penal por excelência das sociedades capitalistas, sua leitura chega a conclusões muito semelhantes às daqueles autores antes citados.

Por fim, a Teoria do Etiquetamento, base da crítica de autores como Alessandro Baratta e também recepcionada em nosso continente, foi responsável pela quebra do paradigma etiológico vivenciado até 1960 nas principais teorias criminológicas, desde as mais

\footnotetext{
${ }^{50}$ Baseado na Universidade de Zuila, na Venezuela, o grupo investigou "questões relativas à violência, ao delito de colarinho branco, à corrupção etc., ainda que o mais essencial para uma história como a que aqui se conta tenha sido a reflexão não sobre as investigações concretas, mas sobre a própria definição de criminologia, que deveria passar, segundo seus autores, da crítica e da denúncia para a conformação de uma nova ordem, mais justa e igualitária". ANITUA, Gabriel Ignacio. Histórias dos pensamentos criminológicos. Rio de Janeiro: Revan, 2008, p. 679-680.

${ }^{51}$ CASTRO, Lola Aniyar. Criminologia da libertação. Rio de Janeiro: Revan, 2005, p. 49.

${ }^{52}$ DEL OLMO, Rosa. A América Latina e sua criminologia. Rio de Janeiro: Revan, 2004, p. 162.
} 
racializadas até as que investiam em causas sociais para explicar o crime, como as teorias da anomia de Émile Durkheim e a sua repaginação realizada por Robert Merton até as das subculturas criminais, da associação diferenciada e tantas outras. O labeling approach deixou como principal contribuição a mudança de pergunta sobre o crime. Não mais "por que alguém pratica um crime?", mas “por que certas condutas são criminalizadas e outras não?”. Aparentemente singela, a nova perspectiva abriu um grande terreno de investigações sobre as agências de controle, seus atores e os efeitos realizados sobre aqueles que a elas se submetiam.

Essas formulações ajudaram a compreender o caráter seletivo do sistema penal e a maneira como ele se formou, reservando aos delitos contra o patrimônio uma maior atenção e abarcando, assim, os mais miseráveis de uma sociedade. Para a compreensão do Brasil pré e pós abolição, essa parecia ser uma lente interpretativa útil: no escravismo, o sistema penal se voltava à proteção da propriedade do homem branco e, portanto, a perseguir escravos que empreendiam fugas, que se insurgiam contra o regime e que se mostravam como insubordinados. No pós-abolição, o sistema penal se dedicaria a garantir o desenvolvimento do incipiente processo de industrialização e de modernização das cidades, recolhendo os indesejados das ruas e treinando-os nos cárceres para se tornarem trabalhadores e membros de família dóceis.

Todas essas conclusões guardam suas procedências e foram, de fato, um guia para ler os dados que apareceram em minhas pesquisas. Porém, alguns dos elementos verificados no campo desafiaram o alcance de parte dessas conclusões, que, em alguns momentos, soaram inconsistentes ou inaplicáveis.

Por exemplo, durante todo o período pesquisado, a prisão brasileira se apresentou como um depósito temporário - e por um tempo bastante curto, como mencionarei - de vagabundos, ébrios, capoeiras, prostitutas e outros indesejados da vida social. Não foi um dispositivo disciplinar e jamais serviu ao treinamento de mão-de-obra para integrarem fábricas, crítica que já vem sendo realizada por uma parte da teoria social brasileira e que explorarei no capítulo 5, relacionando-a ao fenômeno da soberania policial.

Em segundo lugar, essas perspectivas negligenciam o fato de a sociedade brasileira ser racista e, portanto, distribuir vantagens e desvantagens de forma diferenciada não apenas entre pobres e ricos, não proprietários e proprietários, mas entre negros e brancos. A criminologia crítica, nesse aspecto, "manteve-se pouco permeável às contribuições do pensamento negro, do pensamento feminista ou de outros grupos sociais subalternizados e seguiu trabalhando 
com a ideia de classe como categoria explicativa dos fenômenos no âmbito da justiça criminal" $" 53$.

Ao longo desse trabalho esse argumento será aprimorado, mas basta antecipar um exemplo: a polícia pernambucana, ao longo da década de 1920, dedicou-se a inspecionar empregadas domésticas, com o intuito de verificar se tinham saúde para desempenhar suas funções nas casas das famílias brancas, assim como para montar um banco de dados, caso viessem a praticar crimes posteriormente, o que facilitaria a atividade da polícia, como mencionou o chefe de polícia da época, Eurico de Souza Leão. Tratava-se do programa intitulado "Locação de Domésticos" ".

Ocorre que essa inspeção não era uma novidade. No final do século XIX, uma postura municipal do Recife já determinara que mulheres negras amas-de-leite fossem, antes de amamentar, submetidas a exames médicos, evidenciando uma ideia sobre higiene e limpeza que as relaciona às pessoas brancas. Nesse contexto, mulheres brancas se valiam das forças policiais para garantir a sua segurança, de sua família e de seus filhos, uma prática que se perpetuaria por algumas décadas, em um jogo que evidencia como desvantagens só podem existir se, de outro lado, houver vantagens e também como a ameaça da mulher negra à família branca, sobretudo em razão dos estupros sucessivos no período da escravidão e, portanto, do contato entre ela e o homem branco, ainda parecia permear a mente da elite branca brasileira ${ }^{55}$.

Por fim, é preciso mencionar que essas perspectivas, porque tendentes a apresentar interpretações a nível macro e totalizantes da sociedade, por vezes, partem do pressuposto de que as agências do sistema punitivo e, sobretudo, seus atores, estão em perfeita consonância com os projetos políticos do grande capital. Esses projetos, por certo, existem e se transformam em política criminal. Basta, para tanto, verificar o avanço das propostas de privatização de presídios, de ampliação da autorização para uso de arma de fogo, de criação de tipos penais específicos e da descriminalização de outras condutas.

Porém, no nível das interações pessoais, a exemplo daquela entre policiais e os indivíduos em geral, outras variáveis podem estar em jogo, como a obtenção de vantagens, de propina, de favores, de poder. A 'rua' é um espaço de soberania e, como tal, admite a inserção de relações cunhadas pelos códigos extrajurídicos que já mencionei acima e que podem até mesmo fugir à lógica do capital.

\footnotetext{
${ }^{53}$ FREITAS, Felipe. Novas perguntas para a criminologia brasileira: poder, racismo e direito no centro da roda. Caderno CEAS, Salvador, n. 238, p. 488-499, 2016, p. 492.

${ }^{54}$ APEJE, Fundo Secretaria de Justiça, Livro 202, Relatório da Chefia de Polícia, 1928, p. 16-17.

${ }^{55}$ GÓES, Luciano. A “tradução” de Lombroso na obra de Nina Rodrigues. Rio de Janeiro: Revan, 2016, p. 217.
} 
Lola Aniyar de Castro tratou esse último aspecto como "sistema penal subterrâneo", que seria estatisticamente relevante em termos de incidência e população afetada e teria, dentre outras, a característica de "dar preferência à atividade policial, dotada de maior discricionariedade do que qualquer outra, diante das classes menos favorecidas e da população identificada com as classes perigosas" ${ }^{26}$. Evidentemente, o sistema penal subterrâneo é também funcional à lógica capitalista, sobretudo para lidar com os “consumidores falhos" e essa é a perspectiva de Lola. Porém, apesar de mencionar esse aspecto, a autora não se debruça sobre ele, deixando em aberto questões relevantes como o alcance desse sistema informal, seus modos de funcionamentos, suas lógicas de interação e trocas etc.

Parte dessas problemáticas pode ser abrangida por um conjunto de ideias e de autores que tomam o direito em geral e o sistema penal em específico como objetos para pensar como o racismo molda conceitos, verdades e dinamiza as estruturas de poder. Reúno no próximo ponto algumas dessas contribuições, pois, como já dito, elas serão exploradas com pormenor ao longo do texto.

\subsubsection{A perspectiva das teorias raciais aplicadas ao sistema punitivo}

A chegada da República coincide, no Brasil, com o fortalecimento das teses racialistas, que atribuíam o atraso da civilização brasileira ao elemento negro. Nesse período, desenvolvem-se as mais diversas teorias acerca dos caminhos para a modernização, que iam desde a necessidade de expulsão dos africanos e dos descendentes deles até a miscigenação, movimento que conduziria ao branqueamento da sociedade.

O racismo aqui é visto como um dispositivo de hierarquização entre raças, que passam a ser definidas como superiores e inferiores. É fundamental compreender que, a despeito de a ciência racial surgir nos séculos XVIII e XIX, uma prática de dominação de povos brancos sobre povos não brancos vinha sendo empreendida há mais de dois séculos, na conquista e domínio dos povos africanos e latinoamericanos.

De certo, esses continentes já eram um terreno de exploração e investidas colonizadoras e o negro já era representado como espécie inferior, seja porque não devidamente evoluída, seja porque, de fato, descendente de raças menos puras da

\footnotetext{
${ }^{56}$ CASTRO, Lola Aniyar. Criminologia da libertação. Rio de Janeiro: Revan, 2005, p. 125.
} 
humanidade. A cultura africana, os seus modos de vestir, de falar e de se relacionar seriam entendidos pelos brancos europeus como signos de barbárie e do subdesenvolvimento ${ }^{57}$.

Movimento semelhante se deu no território latinoamericano com a descoberta das comunidades indígenas. Para Enrique Dussel, a modernidade seria um movimento político e cultural que não teria se iniciado com o pensamento iluminista, mas, sim, com as incursões colonizadoras dos séculos XV e XVI. É aqui que o homem branco Europeu se choca com os demais habitantes de outros continentes e estabelece uma descrição universal sobre a história que anteporá, ate os dias de hoje, a civilização e a barbárie.

O "descobrimento" é uma experiência estética, contemplativa, na qual os europeus viram, descreveram e conheceram o "novo" mundo. O mais interessante nesse processo de descobrimento, para Dussel, é que a América não "é descoberta como algo que resiste distinta, como o Outro, mas como a matéria onde é projetado 'o si-mesmo'. Então não é o ‘aparecimento do Outro', mas a 'projeção do si-mesmo': encobrimento"58. Ele conclui:

Os habitantes das novas terras descobertas não aparecem como Outros, mas como o Si-mesmo a ser conquistado, colonizado, modernizado, civilizado, como "matéria" do ego moderno. E foi assim que os europeus (particularmente os ingleses) se tranformaram, como dizia antes, nos "missionários da civilização em todo o mundo", especialmente com "os povos bárbaros" $"$.

Mas é óbvio que o empreendimento colonizador e seu encobrimento não se limitam à tentativa de conversão da barbárie em civilização, na violência simbólica, mas é também exploratório e exterminatório. A violência física, a dominação de corpos, o estupro e o assassinato são elementos essenciais e constitutivos desse processo. A modernidade que apregoa o humanismo do "Eu" europeu e branco constitui a desumanidade do "Outro" africano ou americano.

A ciência racialista, portanto, é o aprimoramento discursivo desse processo político, econômico e cultural. A exploração dos negros pelo sistema escravocrata se pautou em ideias preexistentes de inferioridade do africanos, que estariam no nível dos brutos ${ }^{60}$. Para Mbembe,

\footnotetext{
57 SANTOS, Gislene Aparecida dos. A invenção do "ser negro": um percurso das ideias que naturalizaram a inferioridade dos negros. São Paulo/Rio de Janeiro: 2002, p. 55.

${ }^{58}$ DUSSEL, Enrique. 1492: o encobrimento do outro (A origem do "mito da modernidade). Tradução: Jaime A. Clasen. Petrópolis: Vozes, 1993, p. 35.

${ }^{59}$ DUSSEL, Enrique. 1492: o encobrimento do outro (A origem do "mito da modernidade). Tradução: Jaime A. Clasen. Petrópolis: Vozes, 1993, p. 36.

${ }^{60}$ BARROS, José D’Assunção. A construção social da cor: diferença e desigualdade na formação da sociedade brasileira. Petrópolis: Editora Vozes, 2014, p. 75.
} 
a raça constitui, de fato, o principal dispositivo de diferenciação da humanidade entre os homens:

[...] que a raça (ou aqui, o racismo) tenha um lugar tão importante na racionalidade própria ao biopoder é fácil de entender. Depois de tudo, mais que o pensamento em termos de classes sociais (a ideologia que define a história como uma luta econômica de classes), a raça constituiu a sombra sempre presente sobre o pensamento e a prática das políticas ocidentais, sobretudo quando se trata de imaginar a inumanidade de povos estrangeiros e a dominação que se deve exercer sobre eles ${ }^{61}$.

A exploração de negros africanos sob o regime escravocrata, dotado de enorme crueldade, despiu esse corpo negro de sua própria humanidade:

A condição do escravo representa uma tripla perda: perda da casa, perda dos direitos sobre o seu corpo e perda de seu status político. Esta triple perda equivale à dominação absoluta, a uma alienação desde o nascimento e à uma morte social (que é a expulsão fora da humanidade) ${ }^{62}$.

Sendo assim, antes mesmo de qualquer elaboração científica e eugênica sobre as raças, existiu esse modelo, que empreende uma vivência de exploração. A Plantation seria, para Mbembe, a primeira experiência biopolítica ${ }^{63}$, fundada na inscrição da vida nua do escravo na ordem política. Uma vida excluída de qualquer dignidade, uma espécie de morte em vida.

Esses elementos são constitutivos da realidade brasileira. Quando se aboliu a escravidão e se proclamou a República, apesar das várias vozes acerca da desumanidade do escravismo, prospera em termos políticos uma tese que via o sistema escravocrata como um atraso que condenava o Brasil não por causa da barbárie em si do sistema de exploração, mas sim em razão de ter trazido ao nosso país pessoas biologicamente inferiores. Segundo Célia Marinho de Azevedo, essa teria sido uma das teses impulsionadoras das políticas próimigração. Segundo a autora:

\footnotetext{
${ }^{61}$ MBEMBE, Aquille. Necropolítica. Seguido de Sobre el Govierno privado indirecto. Espanha: Editorial Melusina, 2011, p 22.

${ }^{62}$ MBEMBE, Aquille. Necropolítica. Seguido de Sobre el Govierno privado indirecto. Espanha: Editorial Melusina, 2011, p 32.

${ }^{63}$ A leitura realizada por Agamben a respeito do conceito foucaultiano de biopoder põe o campo de concentração como essa experiência por excelência do racismo de Estado, como o "local onde se realizou a mais absoluta conditio inhumana que se tenha dado sobre a terra". AGAMBEN, Giorgio. Homo sacer: O poder soberano e a vida nua. Belo Horizonte: Editora UFMG, 2014, p. 162. A leitura de Mbembe é fundamental para realizar a crítica à invisibilização do holocausto negro.
} 
Argumentos liberais e raciais convergiam para que a suposta irracionalidade da escravidão fosse explicada tanto em termos do caráter compulsório do seu regime de trabalho quanto pela inferioridade racial dos escravos africanos. Esta convergência do liberalismo com o racismo se explicita principalmente a partir da segunda metade do século passado [o século XIX], quando um pensamento especificamente imigrantista começa a se formar no Brasil ${ }^{64}$.

A imigração será, de fato, bastante incentiva - mormente aquela feita por europeus - e o país receberia milhares de italianos, portugueses e espanhóis durante algumas décadas. Como destaca Dora Lúcia, "para o trabalho escravo só os africanos negros serviam e, para o trabalho livre, nem sequer os já brasileiros descendentes de africanos eram aptos, ou melhor, possuíam a ética do trabalho livre" 65 .

Curioso é que, já no início do século XX, os imigrantes também seriam uma questão de segurança pública, representando eles um percentual considerável das prisões em estados como Rio de Janeiro e São Paulo, além de serem identificados a elementos subversivos em razão de alguns estarem vinculados a organizações operárias socialistas ou anarquistas.

Porém, o imigrante jamais apareceu nos discursos jurídicos ou policiais analisados por mim como seres inferiores. Perigosos poderiam até ser, mas jamais dotados de vícios constitutivos, como era o caso dos negros. Boris Fausto chega a conclusões semelhantes ao analisar o fluxo imigratório em São Paulo e os discursos sobre o crime e a criminalidade:

Enquanto a correlação discriminatória entre criminalidade e população de cor constitui um elemento permanente ao longo de todo o período abrangido pela pesquisa, a correlação criminalidade-estrangeiro é conjuntural. Concentra-se no período da imigração em massa, deixando marcas nos relatórios oficiais e nas notícias de alguns jornais ${ }^{66}$.

As revistas policiais e os livros de direito eram permeados das concepções criminológicas positivistas de escolas como a italiana e, nacionalmente, com referências como Nina Rodrigues, reforçando a imagem do negro como bestial em si.

Essa disparidade no tratamento de dois "inimigos" nacionais chamou bastante a minha atenção, porque é fundamental para pensar a racialização do sistema penal não apenas como uma variável da seletividade, mas como algo constitutivo de seus discursos (o bem e o mal/o

\footnotetext{
${ }^{64}$ AZEVEDO, Célia Maria Marinho de. Onda negra, medo branco: o negro no imaginário das elites do século XIX. 3 ed. São Paulo: Annablume, 2004, p. 55.

${ }^{65}$ BERTÚLIO, Dora Lúcia. Direito e relações raciais: uma introdução crítica ao racismo. Dissertação de mestrado. Programa de Pós-Graduação em Direito. UFSC. 1989, p. 106.

${ }^{66}$ FAUSTO, Boris. Crime e cotidiano: a criminalidade em São Paulo (1880-1924). 2 ed. São Paulo: EDUSP, 2001, p. 76.
} 
racional e o emocional) e como elemento fundamental na distribuição de vantagens e desvantagens, incluindo cargos e espaços de poder.

Nesse jogo de vantagens e desvantagens, homens brancos mantiveram um espaço privilegiado no campo jurídico ${ }^{67}$ e da segurança, ocupando os melhores cargos, de governadores a chefes de polícia, de juízes e promotores a professores e doutrinadores do direito. Isso não é pouco quando se considera que, no campo jurídico, há uma concorrência pelo

[...] monopólio do direito de dizer o direito (...) no qual se defrontam agentes investidos de competência ao mesmo tempo social e técnica que consiste essencialmente na capacidade reconhecida de interpretar (de maneira mais ou menos livre ou autorizada) um corpus de texto que consagram a visão legítima ${ }^{68}$.

Assim, esses homens puderam definir programas de política criminal, tipos penais, interpretações sobre tipos penais (como imaginar que o espiritismo fosse criminalizado, mas que apenas o espiritismo negro fosse realmente considerado deletério?) e construíram os sentidos da dogmática penal e processual penal. Enfim, o sistema penal, através da mão desses homens, possuiu uma importante tarefa na construção de sentido sobre o negro que vai muito além do fato de prender mais pessoas negras - o que também é verdade.

Para se ter uma ideia, em 1907, a polícia do Distrito Federal passou por uma grande reforma encampada pelo então chefe de polícia Alfredo Pinto. Dentre as novidades, Pinto criou uma revista científica, o Boletim Policial, no qual publicava os feitos da polícia carioca, mas também textos de cientistas da época sobre crime, investigação, criminosos etc. A revista é uma grande amostra da visão racializada de progresso. A todo o tempo, ela ressalta que os policiais do Império, do passado, os "capoeiras de farda" precisariam ficar para trás, cedendo espaço a uma nova imagem do policial, mais próximo, física e psicologicamente, do policial europeu. Até mesmo alusão à imagem do personagem ficcional de Conan Doyle, Sherlock Holmes, é feita como o modelo ideal. Lélia Gonzalez reflete sobre essa operação como a forma mesma do racismo na América Latina. Para ela,

\footnotetext{
${ }^{67}$ Vou me referir a campo jurídico muitas vezes como o conjunto de pessoas que ocupam cargos de poder e espaços de formação, como professores e doutrinadores, mas também no sentido boudieuniano do termo, em que campo jurídico surge do processo de concentração do capital jurídico nas instâncias do Estado, formando estruturas jurídico-administrativas (juízes, tribunais) e um corpo de juristas engajados em seus papéis. Ver: BOURDIEU, Pierre. Esprits d'État: génese et structure du champ bureaucratique. Actes de la recherche en sciences social, vol. 96-97, p. 49-62, mar 1993. Disponível em < http://www.persee.fr/web/revues/home/prescript/article/arss_0335-5322_1993_num 96_1_3040>, Acesso em 10 ago 2017.

${ }^{68}$ BOURDIEU, Pierre. Poder simbólico. 2 ed. Rio de Janeiro: Bertrand Brasil, 1998, p. 212.
} 
o racismo latino-americano é suficientemente sofisticado para manter negros e índios na condição de segmentos subordinados no interior das classes mais exploradas, graças à sua forma ideológica mais eficaz: a ideologia do branqueamento. Veiculada pelos meios de comunicação de massa e pelos aparelhos ideológicos tradicionais, ela reproduz e perpetua a crença de que as classificações e os valores do Ocidente branco são os únicos verdadeiros e universais ${ }^{69}$.

Essas classificações e valores nortearam, em muito, a formação do aparato punitivo brasileiro. Não será possível, portanto, perder de vista essas contribuições, cujas leituras modificaram a forma como li os dados da pesquisa.

Feita essa breve exposição das teorias que serviram de suporte ao desenvolvimento deste trabalho, passo a apresentar o percurso metodológico de minha pesquisa.

\subsection{CONSIDERAÇÕES METODOLÓGICAS}

\subsubsection{O espaço e o tempo: o centro do Recife entre 1915 e 1930}

Embora a atuação policial em cidades interioranas possa vir a ser um interessantíssimo tema de investigação, escolhi trabalhar com um ambiente urbanizado e em vias de crescimento por diversas razões. Primeiro porque o volume de atuação policial é maior em locais com maior contingente populacional, mas, sobretudo, porque, na passagem para o século XX, o espaço urbano brasileiro se dinamizou bastante com a o fim da escravidão, o êxodo rural e o crescimento, ainda que incipiente, das atividades industriais.

Desde o período colonial, o Recife se transformou em um estratégico ponto de circulação de mercadorias, de onde escoava para a Europa a principal matéria prima produzida nos engenhos do interior, a cana de açúcar. Nas ruas, mulheres e homens, sobretudo negros, circulavam, faziam carga e descarga de navios, vendiam produtos alimentícios, ocupavam uma boa parte do comércio informal. O centro da cidade, composta dos bairros como o de São José, o do Recife e o de Santo Antônio abrigava moradas populares.

Na passagem para o século XX, novas dinâmicas passam a se desenvolver, com a chegada dos veículos automotores, com a realização de eventos culturais, com o cinema, o teatro, os centros universitários, as festas populares, a efervescência das lutas operárias, as disputas políticas e os grandes comícios. Era também o espaço de circulação de crianças e

${ }^{69}$ GONZALEZ, Lélia. A categoria político-cultural da amefricanidade. Revista Tempo Brasileiro, Rio de Janeiro, n. 92/93, jan-jun, p. 69-82, 1988, p. 73. 
adolescentes não integrados a sistemas educacionais, que desempenhavam atividades laborais como a venda de jornais, bilhetes de bonde e de atrações culturais.

De todas essas atividades a polícia se ocupava. Da organização do trânsito à manutenção da ordem nas festas, da questão do menor à censura dos filmes e peças que seriam exibidos. Como veremos, os discursos policiais seguem a tendência da concepção da elite intelectual da época, que via a República como uma era de novidades e modernização. Como destaca Silvia Couceiro,

recém-saído do sistema de governo monárquico, de uma economia baseada na mão-de-obra escrava, de cunho eminentemente agroexportador ainda engatinhando em termos de industrialização, o que o país precisava, na visão dos políticos e intelectuais republicanos, era de reformas urgentes dentro do novo contexto capitalista que se apresentava ${ }^{70}$.

Congregando todos esses elementos, o Recife foi um espaço de "cruzada civilizatória"71 e, portanto, torna-se um espaço privilegiado para pensar o controle policial. Por essa razão, escolhi a capital pernambucana, deixando de lado o restante do estado.

Em relação ao período estudado, eu iniciei a minha pesquisa de campo com o intuito de trabalhar toda a Primeira República, portanto, os anos de 1889 a 1930. Trata-se de uma época bastante explorada na historiografia, justamente em razão da tradicional leitura que se faz da polícia como agente de "modernização a força"72. Porém, como muitos dos trabalhos exploraram a experiência policial no sudeste, sobretudo São Paulo e Rio de Janeiro, entendo ser relevante lançar um olhar sobre uma cidade nordestina. Em segundo lugar, penso que as implicações dessas práticas com o campo jurídico ainda restam pouco exploradas.

Em minha primeira ida ao APEJE, falando que pretendia tratar de práticas e discursos policiais e que, portanto, queria saber se eles possuíam documentos das policias civis e militares, deparei-me com inúmeras fontes, que vão desde os regulamentos dessas e de outras forças policiais, até ofícios recebidos e enviados de diversas autoridades como chefes de polícia, delegados e subdelegados, entre policiais e Ministério Público, entre o judiciário e a polícia etc.

\footnotetext{
${ }^{70}$ COUCEIRO, Silvia. Artes de viver a cidade: conflitos e convivências nos espaços de diversão e prazer do Recife nos anos 1920. Tese de doutorado. Programa de Pós-Graduação em História da UFPE, 2003, p. 29.

${ }^{71}$ COUCEIRO, Silvia. Artes de viver a cidade: conflitos e convivências nos espaços de diversão e prazer do Recife nos anos 1920. Tese de doutorado. Programa de Pós-Graduação em História da UFPE, 2003, p. 29.

${ }^{72}$ BRETAS, M. L.; ROSENBERG, A. A história da polícia no Brasil: balanços e perspectivas. Topoi, vol. 14, n. 26, p. 162-173, jan/jul, 2013, p. 170.
} 
Além disso, no período histórico escolhido, o Recife tinha, inicialmente três delegacias e depois passou a ter cinco, cada uma delas com suas subdelegacias. Certamente, portanto, estariam à minha disposição centenas de livros com outras centenas de páginas, muitos desgastados ou com palavras ilegíveis, demandando muitos anos - quiçá décadas - de consultas e análises.

Rapidamente verifiquei que precisaria realizar recortes e, com ele, perdas. Os primeiros anos da Primeira República pareciam um momento maravilhoso para se pensar o controle policial, já que fatos muito importantes para a ordenação das cidades acabam de ocorrer como a abolição da escravidão, o início das organizações operárias com a incipiente atividade industrial e o êxodo rural. Por outro lado, estudar os últimos anos daquele período traria indiscutíveis vantagens: instituições jurídicas mais sólidas estavam em jogo, junto a uma polícia mais profissionalizada. Ao mesmo tempo, na fase de revisão da bibliografia, encontrei muitos trabalhos que cobriam as primeiras décadas do século XX, a exemplo da tese de doutorado em história de Clarissa Nunes Maia, que se debruçou sobre as práticas policiais, no Recife, de 1889 a 1915 e consultou os documentos do APEJE, assim como eu fiz.

Assim, premida pela necessidade de fazer um recorte temporal, decidi seguir a leitura das fontes a partir de 1915, estabelecendo, portanto, o meu período de análise de documentos policiais de 1915 a 1930.

Evidentemente, no processo de garimpagem realizado no arquivo fui, muitas vezes, colocada diante de materiais relativos a anos anteriores que não deixei de consultar, posto que poderiam sempre ajudar na tarefa de costurar as informações acerca da formação dessas forças policiais e de suas práticas.

\subsubsection{As fontes consultadas}

A atividade policial pode ser investigada a partir de múltiplas fontes: a dos arquivos da própria organização, processos judiciais, jornais, doutrina jurídica, regulamentos policiais, revistas policiais, relatórios estatísticos do governo. A vastidão de pontos de vista e de narrativas é enorme e demandaria de mim muito mais do que o tempo que o doutorado me concedeu. Sendo assim, desde o princípio, foquei nas fontes da própria organização policial, isto é, nos documentos produzidos pela polícia, especialmente a polícia civil e, secundariamente, a militar. Neste último caso, deixei de lado as fontes por elas não estarem disponíveis no APEJE. Na época pesquisada, a polícia militar se chamava Corpo Policial e os documentos a ele referentes se restringem aos regulamentos e legislações pertinentes a sua organização interna. 
Mas, o que eu consegui acessar nos arquivos da polícia civil? Uma primeira importantíssima fonte foram os livros de ofícios de delegados e subdelegados enviados aos chefes de polícia, nos quais relatam o cotidiano das atividades de suas delegacias (ocorrências criminais, prisões, suicídios, acidentes, problemas administrativos, questões relativas aos prédios, ao efetivo policial, ao policiamento nas áreas que abrange etc). Esses livros são anuais e cada delegacia possui um. Quando consultei o catálogo do APEJE, verifiquei, portanto, que somente em relação a esses livros, eu teria cerca de 70 volumes a consultar. Cada volume contem ofícios praticamente diários informando sobre as ocorrências policiais. Ao final, seriam mais de 20 mil ofícios a serem manuseados, ainda que não inteiramente analisados.

Desse modo, o caminho só poderia ser um: escolher apenas uma das delegacias do Recife para analisar os seus cerca de 15 livros e em torno de cinco mil ofícios. Mas qual delegacia escolher? Meu critério foi o de movimento, isto é, a delegacia que mais atividades registrava na cidade. Consultando esses dados nos relatórios anuais da Chefia de Polícia, verifiquei que a $1^{\text {a }}$ Delegacia da Capital era a principal responsável pelos fluxos de ocorrências policiais e prisões. Sem dúvidas, era a delegacia sobre a qual eu deveria me debruçar, pois foi, ao longo de todo o período, a de maior movimento.

No Relatório da Chefia de Polícia relativo ao ano de 1912, havia o quantitativo de prisões realizadas por autoridade responsável. O quadro era o seguinte:

Tabela 1: Autoridade responsável pela ordem de prisão ${ }^{73}$

\begin{tabular}{lr}
\hline Chefe de polícia & 91 \\
\hline $1^{\circ}$ Delegado & 93 \\
$2^{\circ}$ Delegado & 99 \\
$3^{\circ}$ Delegado & 66 \\
Subdelegado de Santo Antonio & 864 \\
Subdelegado de São José & 117 \\
Subdelegado de São José & 74 \\
Subdelegado de Afogados & 116 \\
Subdelegados da 2 & Delegacia \\
Subdelegados da $3^{\circ}$ Delegacia & 297 \\
\hline
\end{tabular}

Das 2.327 prisões realizadas no ano de 1912 no Recife, 49,3\% foi de responsabilidade de autoridades da $1^{\text {a }}$ delegacia (o delegado ou os subdelegados das unidades que a compunham, que era Santo Antônio, Recife e São José), havendo, inclusive, expressiva

\footnotetext{
${ }^{73}$ Fonte: APEJE, Fundo SG, volume 200. Relatório da Chefia de Polícia, 1912.
} 
participação das prisões realizadas no Bairro de Santo Antônio (37,1\% delas), que possui mais prisões do que qualquer outro bairro da cidade.

Em 1927, após uma reforma empreendida em meados da década de 1920, o Recife passou a contar com cinco delegacias distritais, que cobriam os seguintes bairros:

Tabela 2: Relação de delegacias e bairros do Recife - $1927^{74}$

\begin{tabular}{ll}
\hline Delegacia & Bairros \\
\hline $1^{\circ}$ Distrito & Santo Antonio, Recife, São José e Ilha Fernando de Noronha \\
$2^{\circ}$ Distrito & Boa Vista, Pombal, Santo Amaro, parte do Espinheiro e Capunga \\
$3^{\circ}$ Distrito & $\begin{array}{l}\text { São José (partindo da Rua São Joao), Afogados, Imbiribeira, Pina, Boa Viagem, } \\
\text { Areias, Barro e Tejipió. }\end{array}$ \\
$4^{\circ}$ Distrito & Torre, Madalena, Caxangá, Cordeiro, Iputinga, Zumby e Várzea \\
$5^{\circ}$ Distrito & Encruzilhada, Casa Amarela, Poço da Panela, Campo Grande, parte de Santo \\
& Amaro (partindo da ilha de Limoeiro), Apipucos, Casa Forte, Monteiro, Matinha \\
& Tamarineira, Aflitos, Dois Irmãos e Brejo dos Macacos \\
\hline
\end{tabular}

Em relação às queixas levadas à Polícia, o maior número delas vinha dos $3^{\circ}$ e $5^{\circ}$ distritos, totalizando, em 1927, 611 e 545, respectivamente. Já o $1^{\circ}$ distrito registrou 132 queixas. Porém, quando o número é relativo às prisões conduzidas por cada uma das delegacias, verifica-se uma grande atividade do $1^{\circ}$ Distrito, a antiga $1^{\text {a }}$ Delegacia, de modo a se concluir que, em todo o período pesquisado, foi mesmo a área de maior atuação repressiva da polícia.

Tabela 3: Movimento das delegacias do Recife (queixas e prisões) - $1927^{75}$

\begin{tabular}{ccc}
\hline Delegacia & Número de queixas & Número de prisões \\
\hline $1^{\circ}$ Distrito & 132 & 1453 \\
$2^{\circ}$ Distrito & 230 & 404 \\
$3^{\circ}$ Distrito & 611 & 369 \\
$4^{\circ}$ Distrito & 307 & 477 \\
$5^{\circ}$ Distrito & 545 & 467 \\
Total & 1825 & 3170 \\
\hline
\end{tabular}

O que acontecia nas ruas de Santo Antonio e de São José para haver tão expressivo número de detenções, totalizando praticamente a metade das realizada em toda a cidade do Recife?

No Relatório da Chefia de Polícia de 1927, Eurico Leão descreve o bairro de Santo Antonio como

\footnotetext{
${ }^{74}$ Fonte: APEJE, Fundo Secretaria de Justiça, Livro 202, Relatório da Chefia de Polícia, 1928.

${ }^{75}$ Fonte: APEJE, Fundo Secretaria de Justiça, Livro 202, Relatório da Chefia de Polícia, 1927.
} 
zona propriamente comercial e onde é localizado o porto da cidade, estando nela instalada a maior parte do meretrício, que tive de fiscalizar e reprimir nos seus excessos, e sendo, ainda, o centro procurado, de preferência, pelos contraventores do jogo de azar e pelos viciados de todas as espécies, a atividade desta delegacia teve de se desdobrar vultosamente ${ }^{76}$.

Sendo assim, consultei todos os livros de ofícios de delegados e subdelegados da $1^{\text {a }}$ Delegacia da Capital, de 1915 a 1930.

Também consultei os relatórios anuais da Chefia de Polícia de Pernambuco, os quais foram particularmente difíceis de serem encontrados, por se encontrarem em diferentes fundos no APEJE. Assim, estavam em livros da Secretraria de Defesa Social, da Secretaria Geral e da Secretaria de Justiça, que possuem, por seu turno, uma infinidade de outras temáticas sem que tais relatórios estivessem destacados. Foi preciso, portanto, folhear vários livros até encontra-los.

Os relatórios constituem uma fonte crucial para a compreensão das dinâmicas policiais no período porque, além de possuírem esquematicamente as estatísticas criminais, trazem as opiniões da Chefia de Polícia sobre criminalidade, política criminal e organização policial.

Outra fonte consultada foram os livros de ofícios de chefes de polícia, no qual autoridades de todo o Brasil trocam informações sobre temas nacionais de segurança pública. Os livros consultados foram relativos aos anos de 1912, 1914, 1918, 1922 e 1927.

Também consultei os relatórios da Força Pública, de 1916 a 1918, nos quais é possível visualizar situações consideradas críticas pelo governo a ponto de demandar a intervenção dessa força especial de segurança.

Ainda no APEJE, consultei os regulamentos e legislações do período acerca da organização policial. Nesse caso, compreendeu todas as forças policiais do período, isto é, a polícia civil, a Guarda Municipal, o Corpo Policial, a Força Pública, a Segurança Noturna e o Corpo de Segurança, Investigação e Capturas.

Além do APEJE, realizei buscas no acervo histórico da Faculdade de Direito do Recife, onde obtive outras fontes que foram fundamentais para essa tese. Primeiramente, os livros de processo penal do período, já que a biblioteca possui uma grande variedade deles. Consultei vários deles publicados entre 1841 a 1930. O período se justificava pelo seguinte: foi em 1841 e 1842 que o Código de Processo Criminal do Império de 1832 sofreu mudanças que expandiram o poder policial, permitindo, como disse acima, que delegados julgassem os, à época, denominados "crimes policiais". Então, eu procurava verificar como a doutrina

\footnotetext{
${ }^{76}$ APEJE, Fundo Secretaria de Justiça, Livro 202, Relatório da Chefia de Polícia, 1928, p. 156.
} 
processual penal se comportaria frente a essa ampliação de atribuições e como ela teria reagido à supressão desse poder com a lei 2.033 de 1871. No que tange ao restante do período, eu mantive a consulta porque significava acessar o pensamento dos doutrinadores sobre a polícia e poder de polícia exatamente no período por mim investigado, a primeira República.

Ainda no acervo da FDR, consultei os números dos quatro primeiros anos do Boletim Policial, revista da polícia civil do Distrito Federal, que teve grande circulação à época e constitui uma fonte relevante para a compreensão das representações das cúpulas policiais sobre as temáticas mais diversas relativas à segurança e à ordem públicas.

Consultei, também, na FDR, o primeiro volume dos Anais da Conferência JudiciáriaPolicial de 1917. O volume 2 dos anais eu obtive graças ao apoio de Hugo Leonardo Santos, pesquisador do Grupo Asa Branca de Criminologia, que me pôs em contato com Marco Alexandre, pesquisador do Rio de Janiero, que, gentilmente, concedeu-me as cópias que ele possuía.

Por fim, consultei os números da Revista Acadêmica da Faculdade de Direito do Recife entre 1891 (ano da primeira publicação) a 1897 e entre 1908 até 1930 ${ }^{77}$, fonte fundamental para compreender o pensamento jurídico e criminológico dos professores e doutrinadores que frequentaram aquela casa no período, de onde saíam chefes de polícia e delegados, além dos governadores do Estado de Pernambuco.

\subsubsection{Os limites das fontes históricas}

Como exposto, consultei fontes variadas, que podem ser agregadas em dois grandes grupos: fontes governamentais (leis, regulamentos, ofícios e demais documentos policiais) e fontes literárias (doutrina jurídica e policial especializadas). Cada uma delas apresenta possibilidades interessantes de ingressar no imaginário de uma época e dos sujeitos que as produziram, embora também estejam cobertas de problemas que precisam ser explicitados.

Normalmente, o trabalho com fontes oficiais do Estado já implica uma série de limites, uma vez que constituem versões oficiais de fatos que não necessariamente se passaram da forma como descrito. Ainda, apresentam esses documentos ausências que podem constituir estratégias das agências estatais em busca de encobrir práticas não autorizadas ou não simpáticas ao público. Portanto, certamente uma premissa fundamental para pesquisar com esses documentos é saber que eles podem não dizer a verdade ou toda a verdade.

\footnotetext{
77 Os números da revista nos anos de 1898 a 1907 não estavam digitalizados.
} 
Como lembra Howard Becker, "muitas vezes cientistas sociais usam informação colhida por outras pessoas e organizações e, em consequência, desconsideram tudo aquilo que estas desconsideraram"78 e disso não se pode fugir quando se consulta documentos policiais ou judiciais. Porém, a dificuldade apresentada não invalida as pesquisas com fontes oficiais, afinal, todo o conteúdo encontrado em uma fonte oficial pode ser elucidativo, inclusive, sobre as escolhas institucionais. O que essas agências decidem dizer em público? Que discursos elas sustentam sobre elas próprias e sobre a temática com as quais trabalham? Quais as suas prioridades?

No caso das fontes históricas e oficiais, outro problema se agrega a esse: a preservação dos documentos. Desse modo, se é um desafio resgatar alguma narrativa em processos judiciais ou inquéritos policiais hoje, o que dizer de procedimentos desenvolvidos há mais de um século? Não raramente, encontrei ofícios cujo conteúdo apenas parcialmente pode ser acessado, porque parte do documento já estava plenamente destruído. Outro obstáculo é o fato de a maior parte dessa documentação estar manuscrita a caneta, demandando para a sua leitura compreender a caligrafia de cada pessoa que o produziu. Vez por outra as palavras eram para mim simplesmente ilegíveis.

Desse modo, no tocante aos documentos colhidos no arquivo, é preciso ter em mente as possibilidades que ele apresenta para o trabalho. Possibilidades estas dadas pelos próprios limites do tipo da fonte. Como destaca Barros:

A tarefa do historiador, certamente, não será a de julgar um crime, mas
avaliar representações, expectativa, motivações produtoras de versões
diferenciadas, condições de produção destas versões, além de captar a partir
da documentação detalhes que serão reveladores do cotidiano, do
imaginário, das peculiaridades de um grupo social, das suas resistências, das
suas práticas e modos de vida ${ }^{79}$.

Já as demais fontes consultadas, como os livros e as revistas científicas, não foram atingidas pela dificuldade da preservação, por estarem todas em ótimo estado, mas, de fato, também merecem os seus cuidados no trato do conteúdo. Como lembra Koselleck, quando nos voltamos a textos antigos, temos "a obrigação de compreender os conflitos sociais e políticos do passado por meio das delimitações conceituais e da interpretação dos usos da

\footnotetext{
${ }^{78}$ BECKER, Howard. Segredos e truques da pesquisa. Rio de Janeiro: Jorge Zahar Editor, 2007, p. 135.

${ }^{79}$ BARROS, José d'Assunção. Fontes históricas. Revista de História, Campo Grande, v.2, n. 3, p. 71-115, jan/jun, 2010, p. 82 .
} 
linguagem feitos pelos contemporâneos de então" 80 . No campo jurídico, não há como efetivamente fugir dessa advertência.

Conceitos fundamentais com os quais lidamos, como já afirmei acima, são construídos a partir das experiências e expectativas dos sujeitos de cada época. Não é possível, portanto, apreender um texto a partir da nossa visão de hoje, sob pena de incorrermos em anacronismos. Como destaca Hugo L. Santos: "acreditar que os conceitos valem por si sós, que seu significado pode ser pinçado da linguagem, sem a consideração de condicionamentos sociopolíticos, é um grande equívoco - aliás, bastante comum entre juristas, que costumam idealizar seus conceitos" $" 81$.

Portanto, são com essas advertências e cuidados metodológicos que procurei nos próximos capítulos desenvolver meus argumentos, explorando ao máximo a potencialidade de minhas fontes, mas bastante ciente de seus limites.

${ }^{80}$ KOSELLECK, Reinhart. Futuro passado. Rio de Janeiro: Contraponto Editora, 2006, p. 103.

${ }^{8}$ SANTOS, Hugo Leonardo. Por uma história crítica dos conceitos jurídico-penais: fundamentos teóricometodológicos a partir de uma aproximação entre Michel Foucault e Reinhart Koselleck. Programa de PósGraduação em Direito da Universidade Federal de Pernambuco. Tese de Doutorado. 2015, p. 182. 


\section{AS POLÍ́CIAS NO INÍCIO DA REPÚBLICA ENTRE O SONHO CIVILIZACIONAL E AS PRÁTICAS INFORMAIS NO COTIDIANO DE FAMÍLIAS POBRES E NEGRAS}

Vasculhar os arquivos históricos da polícia é adentrar um universo nada fácil de ser interpretado. Já ponderei sobre a problemática relativa a esse tipo de fonte, que, além de representar as versões oficiais dos próprios policiais sobre suas atividades, é extremamente antiga e, muitas vezes, incompleta e desgastada. O caminho é reunir os retalhos dessas informações, tendo a consciência de que ali se encontra apenas o ponto de vista de uma parte das agências do sistema de justiça criminal.

Porém, esse ponto de vista é bastante valioso. Nele estão representações da polícia sobre o que deveria ser a sua tarefa na sociedade, o que seria efetivamente realizado, o que aqueles sujeitos pensavam do crime e do criminoso, das cidades e da justiça. Não se trata de verdades ou inverdades, mas de registros úteis à reconstrução da trajetória do sistema punitivo.

Os principais projetos da República brasileira - ordem e progresso - demandaram a atividade direta das polícias, administrando com ampla liberdade as camadas de desordeiros e incivilizados. Por certo, a polícia passaria a ser regulada e limitada pelos documentos jurídicos, além de ter seu papel restringido pelas modernas concepções de divisão de poderes, tão presentes entre republicanos brasileiros. Nesse modelo, as Guardas Civis, o Corpo Policial, a Força Pública e a Polícia Civil desempenhariam seus papeis subordinados à legalidade e ao controle judicial de seus atos.

Porém, ao analisar o cotidiano da polícia na cidade do Recife, entre 1915 e 1930, e várias fontes secundárias sobre prática policial no final dos oitocentos e início do século XX, encontrei uma realidade que foge por completo aos manuais e cursos de processo penal e demais obras do campo jurídico brasileiro. Neste cenário, a polícia desempenhava papeis de ordenamento da vida e da cidade que iam para muito além da prevenção da criminalidade e investigação de delitos.

Enquanto o desenho institucional brasileiro se referia à polícia judiciária e administrativa, atribuindo àquela a única função de instruir autos de inquérito sobre crimes, que seriam, posteriormente, analisados pelo poder judiciário e a esta a prevenção do delito, as forças policiais operavam soberanamente nas ruas, constituindo quase uma jurisdição administradora de conflitos os mais diversos. No capítulo anterior já delimitei o alcance conceitual dessa soberania e, nos próximos, procurarei abordar a relação do campo jurídico 
com esse fenômeno e a maneira como a soberania se expressa em práticas e discursos policiais.

Neste capítulo, viso a realizar uma breve incursão sobre a formação das polícias no Brasil e, em especial, das polícias do Recife.

Uma ressalva é crucial: é um equívoco falar da polícia no início do período republicano como uma realidade uniforme. Primeiramente porque não existia, como ainda não existe, uma única polícia. Sob esta denominação, é possível se referir, no âmbito dos estados, à polícia judiciária ou à polícia administrativa (que fazia policiamento ostensivo, era militarizada e recebia diferentes nomes a depender do estado) e, das cidades, às polícias municipais, comumente referidas como Guardas Civis. Também ao longo do século XIX, foram criadas e extintas dezenas de forças policiais, com diferentes objetivos, composição e forma de organização.

No mais, pelo fato de as polícias serem administradas por autoridades locais de cada Estado (e província na época do Império), os particularismos são frequentes e deverão ser, sempre que possível, mencionados. Isso não implica dizer que as interpretações aqui formuladas sobre o funcionamento da máquina policial no Recife não possam ajudar a pensar o controle penal no início da República. Ao contrário, é o esforço de dialogar o local e o geral que poderá nos conduzir a uma compreensão melhor da temática.

\subsection{O SURGIMENTO DAS FORÇAS POLICIAIS}

Entre os séculos XVIII e XIX, praticamente todos os países da Europa ocidental já teriam as suas forças policiais em moldes cada vez mais burocratizados, profissionalizado e baseados em princípios de hierarquia e disciplina. Para Jean Claude Monet, um elo imediato associa polícia e soberania do Estado, de modo que a polícia pública reveste-se da função de garantir a segurança interna desse Estado, relacionando-se com o conceito de "Razão de Estado" $" 8283$.

Naquele continente, as primeiras experiências de forças policiais, vinculadas às monarquias absolutistas, datam do século XVI e muitas delas não estão ligadas a estatutos jurídicos rígidos, sendo desempenhadas por agentes públicos ou privados, por milícias de bairros ou grupos comunitários. Entre séculos XIX e XX, a maioria dessas organizações se

\footnotetext{
${ }^{82}$ MONET, Jean-Claude. Polícias e sociedades na Europa. São Paulo: Edusp, 2001, p. 16.

83 As polícias, como instrumentos de segurança e dispositivos de controle dos Estados Modernos, possuem a sua estrutura e o seu funcionamento diretamente relacionados aos empreendimentos de inclusão e exclusão e à Razão de Estado. Em tempos de declarações de direitos humanos, os Estados de Direito recém-formados nos séculos XVIII e XIX operarão sempre a partir de uma distinção clara entre cidadãos e inimigos, distribuindo a cada um deles, respectivamente, a Constituição e a Exceção.
} 
torna efetivamente mais profissionalizada e adquire o monopólio da força pública, assumindo duas tarefas primordiais: a de principal porta de entrada dos sistemas penais e, ao mesmo tempo, de arma contra dissidentes políticos e sublevações que permeavam as sociedades europeias nesse período ${ }^{84}$.

Como se mantem a ordem? Quem representa a ela uma ameaça? As implicações políticas dessas perguntas são inevitáveis e me conduziu a algumas leituras sobre razão de estado, segurança, inimigos públicos etc. A razão de Estado autoriza "o uso da força ou meio de exceção a serviço do poder" ${ }^{\nexists 5}$. Em sociedades autoritárias, a razão de estado estará expressamente a serviço das classes dominantes, jogando no campo da exceção todos os dissidentes. Para Prado,

em regime autoritário nem todas as demandas são expostas e o critério de atendimento não é uniforme e impessoal. Por óbvio, o sistema penal é chamado a calar os dissidentes e toda classe de pessoas que se insurgem contra a arbitrária distribuição de bens e valores ${ }^{86}$.

Nessas configurações, não restam dúvidas de que o governante quebra a lei em nome de seu governo e de supostos interesses de segurança nacional. Em outras palavras, o "golpe de Estado" é visível. Porém, como destaca Romano, "nem todo golpe se resume à quartelada. Pelo contrário, os golpes de Estado mais bem sucedidos são inapercebidos pela maioria, consistem nas 'leituras' enviesadas das Constituições em proveito de interesses governamentais ou de mercado"87. Assim, complementa, "golpe e razão de estado suspendem o direito e a justiça" 88 . Walter Benjamin, ao se referir à polícia, lembra que “o 'direito' da polícia assinala o ponto em que o Estado, seja por impotência, seja devido às conexões imanentes a qualquer ordem de direito, não consegue mais garantir, por meio dessa ordem, os fins empíricos que ele deseja alcançar a qualquer preço" $" 8990$.

Nesse aspecto, as polícias são inexoravelmente convocadas à manutenção da própria autoridade do direito e do Estado. Em situações de ameaça à ordem, a força repressiva policial estaria autorizada a agir, não havendo propriamente limites a essa atuação, posto que os

\footnotetext{
${ }^{84}$ MONET, Jean-Claude. Polícias e sociedades na Europa. São Paulo: Edusp, 2001, p. 55.

${ }^{85}$ ROMANO, Roberto. Razão de Estado e outros estados de razão. São Paulo: Perspectiva, 2014, p. 48.

86 PRADO, Geraldo. Sistema acusatório: a conformidade constitucional das leis processuais penais. Rio de Janeiro: Lumen Juris, 2005, p. 64.

${ }^{87}$ ROMANO, Razão de Estado e outros estados de razão. São Paulo: Perspectiva, 2014, p. 59.

${ }^{88}$ ROMANO, Razão de Estado e outros estados de razão. São Paulo: Perspectiva, 2014, p. 60.

${ }^{89}$ BENJAMIN, Walter. Escritos sobre mito e linguagem. São Paulo: Duas Cidades; Editora 34, 2011, p. 135.

90 Ainda, na concepção do autor, a polícia concentra as duas foras de violência do direito: a instauradora e a conservadora. A violência instauradora da polícia é a possibilidade de ela representar a força de uma ordem vencedora, conquistadora e a violência conservadora está na sua tarefa de manutenção do poder do Estado.
} 
limites não poderiam ser previstos antes mesmo do surgimento da situação crítica. Em suma, as polícias seriam organizações com vocação para agir fora da legalidade.

Nos Estados Modernos são organizações que lidam sempre com uma tensão entre atuar conforme o direito e ser, ao mesmo tempo, convocada a fugir ao direito, adentrando o tormentoso espaço da exceção, da emergência ou da urgência em tempos de crise, embora seja sempre possível disputar uma atuação mais democrática e legal por parte delas ${ }^{91}$.

Mas não apenas de atividade repressiva vivem as polícias. Maximo Sozzo, utilizandose do instrumental teórico foucaultiano, aponta para o surgimento da polícia no século XVIII como uma estrutura ao mesmo tempo disciplinar e de biopoder. Uma instituição que se volta ao homem-espécie e, ao mesmo tempo à multiplicidade dos indivíduos, na medida em que formam uma 'massa global' afetada por processos de conjunto (o nascimento, a morte, a produção, as doenças $)^{92}$.

Nessa concepção, a polícia desempenharia papeis de normalização e ajustamento do corpo social, com efetiva capacidade de exclusão dos elementos daninhos à sanidade social. Voltar-se-ia, segundo Sozzo, a uma afirmação da ética do trabalho e da moralidade burguesas e, ao mesmo tempo, recolheria das ruas aqueles sujeitos irrecuperáveis. Ela age em conjunto a outras instituições, como as prisões, os manicômios, as forças armadas etc. Na Argentina, no Brasil e em outros países do mundo ocidental, as polícias surgiram perseguindo vagabundos, mendigos, trabalhadores subversivos e prostitutas nas ruas, encaminhando-os, em seguida, àquelas outras instituições, definidas por Foucault, como disciplinadoras ou normalizadoras. Desse modo, à repressão se alia a normalização.

Essa interpretação a nível macrossociológico do surgimento das polícias nos oferece interessantes pistas para a compreensão dessas organizações no Brasil. Porém, elas praticamente silenciam a respeito das implicações dos processos de racialização na construção das práticas policiais no país e, por vezes, ao colocar a polícia em um papel definido e estático - repressor e normalizador - não permite que se atente para as complexas e contraditórias relações que a polícia desempenhava nos bairros pobres e negros das cidades brasileiras.

Desse modo, farei o esforço de pensar as polícias não apenas a partir dos papeis jurídico e político oficialmente a elas atribuídos ou a partir das leituras das teorias críticas, mas também a partir das suas práticas cotidianas, que ora reforçam aquelas imagens e ora

\footnotetext{
${ }^{91}$ Como destaca Manuel Valente, “a política criminal humanista ou do cidadão exige uma Polícia defensora, garantidora e respeitadora dos direitos humanos, razão do seu ser e limite do seu agir". VALENTE, Manuel Monteiro Guedes. A polícia do Estado Democrático de Direito. Florianópolis: Empório do Direito, 2015, p. 62

92 SOZZO, Maximo. Polícia, governo e racionalidade: incursos a partir de Michel Foucault. Discursos Sediciosos. Rio de Janeiro: Revan, ano 17, número 19/20, 2012, p. 511-554.
} 
desviam-se delas, conduzindo o pesquisador a um universo intrigante e difícil de ser enquadrado em esquemas teóricos rígidos.

A primeira experiência policial, no Brasil, foi a Intendência Geral de Polícia da Corte e do Estado do Brasil, criada pelo Alvará Régio de 10 de maio de 1808 depois da chegada da família real ao nosso território. A intendência possuía prerrogativas bastante genéricas, desde a responsabilidade por obras públicas até a investigação de crimes e captura de criminosos. Junto a ela, havia a Divisão Militar da Guarda Real de Polícia, criada em 1809, que atuava em tempo integral e com ampla autoridade para manter a ordem nas cidades ${ }^{93}$.

Ao longo do período Imperial, diversas outras forças policiais foram organizadas e, em seguida, dissolvidas, havendo, ainda, um constante conflito entre a autoridade central (Real) e as locais (províncias). O Código de Processo Criminal de 1832 é um excelente exemplo dessa configuração, quando regulamentou a atuação dos juízes de paz, eleitos nas cidades e com competências policiais e judiciais. Já em 1841 e 1842, reformas realizadas naquele Código retiraram a autoridade dos juízes de paz e a passou para chefes de polícia e delegados - então escolhidos por representantes do Império nas Províncias - com a finalidade de descentralizar a justiça e enfraquecer a política das cidades e das províncias. Falarei adiante sobre as implicações dessas reformas.

Em 1831, foi criada a Guarda Nacional, uma força policial civil, composta de cidadãos com renda suficiente para poderem votar. Essa guarda pretendeu enfraquecer o Exército e era efetivamente subordinada aos interesses dos senhores de engenho e outros membros das elites locais, sendo por eles praticamente financiada ${ }^{94}$. Fazia, ademais, policiamento nas vilas e cidades, mesmo não se tratando, propriamente, de uma polícia. O surgimento da Guarda Nacional foi um esforço da classe senhorial, que fazia oposição ao Imperador, mas não se pode perder de vista que ela aparecia também em um período de muitas sublevações negras e escravas, como pontuei no capítulo anterior.

Também em 1831, pela lei de 10 de outubro, o então ministro da Justiça, Diogo Antonio Feijó, autorizou a criação de outra força policial provincial, o chamado Corpo de Guardas Municipais Permanentes, que atuou até o fim do Império.

No primeira metade do século XIX, muitas já eram as forças repressivas existentes para vigiar as cidades: a Guarda Nacional, o Corpo de Guardas Municipais Permanentes e os

${ }^{93}$ BRETAS, Marcos Luiz. Ordem na cidade: o exercício cotidiano da autoridade policial no Rio de Janeiro: 1907-1930. Rio de Janeiro: Rocco, 1997, p. 41.

${ }^{94}$ Para uma abordagem detalhada dessa força, ver: SILVA, Wellington Barbosa da. Entre a liturgia e o salário: a formação dos aparatos policiais no Recife do Século XIX (1830-1850). Tese de Doutorado. Recife: Universidade Federal de Pernambuco, PPGH, 2003, p. 35. O autor comenta que boa parte dos custos da Guarda Nacional era pago pelos próprios oficiais da milícia. 
juízes de paz (estes últimos verdadeiros juízes policiais). Todos teriam atribuições de prender desordeiros de um modo geral, de reprimir ajuntamentos de pessoas, de impedir a presença de determinados grupos em certos horários, enfim, de controlar a circulação de corpos nos espaços públicos. A esse controle se somava o privado, exercido por senhores de engenho ou cidadãos comuns, estes últimos autorizados pelo Império através da decisão de Justiça de $\mathrm{n}^{\circ}$ 205 de 27 de julho de 1831, que permitia que "moradores em lugares desertos e nos arrabaldes das cidades" se "encarregassem da prisão dos negros capoeiras ou de qualquer outro indivíduo que esteja cometendo crime ou dispondo-se para tal"95.

Além dessas agências de policiamento ostensivo, havia ainda a polícia judiciária composta de delegados e subdelegados que promoviam investigação dos crimes, mesmo antes da efetiva criação do Inquérito Policial em 1871 pela Lei 2.033. Enfim, no início do Período Republicano, já possuía o Brasil polícias de caráter administrativo e judiciário, assim expressamente definidas desde aquela lei.

Em Pernambuco, existia o Corpo Policial, instituído em 1896, responsável pelo policiamento ostensivo $^{96}$; a polícia civil, organizada em 1898 e de natureza judiciária; o serviço de identificação (uma seção da Repartição Central de Polícia), criado em 1909 e a Guarda Civil, criada em 1893, que também fazia policiamento nas cidades. Além dessas organizações de natureza pública, Recife contou ainda com um serviço particular, organizado por um delegado de polícia, Hemetério Maciel, denominado Segurança Noturna, regulamentado em 1909. No anexo 1, consta um organograma das forças policiais pernambucanas e recifenses existentes no período. Em seguida, serão expostos com mais detalhes a organização e atribuição do Corpo Policial e da Polícia Civil, forças que protagonizaram as narrativas dos arquivos policiais consultados.

O Corpo Policial em Pernambuco foi organizado através de um regulamento expedido em 25 de agosto de 1896, pelo governador Joaquim Corrêa de Araújo, com autorização da lei $\mathrm{n}^{\mathrm{o}} 181$ de 8 de junho do mesmo ano ${ }^{97}$. Esse Corpo, militarizado e que corresponde hoje à Polícia Militar, era composto de uma companhia de cavalaria e dois batalhões $\left(1^{\circ}\right.$ e $\left.2^{\circ}\right)$ de infantaria. Os comandantes e oficiais do Corpo Policial eram empregados de confiança do governador do estado, de acordo com o artigo 12 do referido regulamento. Para a função de

\footnotetext{
${ }^{95}$ MATOS, Ilmar Rohloff de; CARVALHO, Maria Alice R. de. A polícia e a força policial no Rio de Janeiro. Estudo das características histórico-sociais das instituições policiais brasileiras, militares e paramilitares, de suas origens até 1930. Rio de Janeiro: PUC, 1981, P. 87.

${ }^{96} \mathrm{O}$ artigo 102 do regulamento, ao tratar das rondas policiais, afirma que os soldados deveriam agir com prudência e não devem produzir maus-tratos nos presos. O corpo policial, ao final, é subordinado ao governo do estado, que poderá movê-los de acordo com a necessidade.

${ }^{97}$ APEJE, Caixa 2. Regulamento do Corpo Policial, expedido em 25 de agosto de 1896, pelo governador Joaquim Corrêa de Araújo, 1896.
} 
comandante, o governador poderia designar um oficial ativo ou reformado do exército, se houvesse autorização do Governo da União. O quadro dos batalhões era preenchido por alistamento voluntário, por tempo de quatro anos completos e, para fazer parte dele, era preciso ter entre 18 e 40 anos, além de robustez e moralidade (artigos 24 e seguintes), não havendo exigência de nível educacional.

Já a lei estadual no 310, de 1898, regulamentou a administração policial no Estado, prevendo quatro cargos: chefe de polícia, delegado, subdelegado e inspetor de quarteirão. $\mathrm{O}$ chefe de polícia - necessariamente uma pessoa formada em direito e com, no mínimo, quatro anos de experiência - era escolhido pelo governador. Essa foi uma mudança trazida pela República, ao retirar da autoridade central a competência de nomear os chefes de polícia, o que proporcionou bastante autonomia aos estados.

Eles ainda participariam da deliberação de todos os demais cargos da polícia civil. Propunham ao Secretario de Justiça do Estado os nomes para as carreiras de delegado, subdelegado e suplentes e eram responsáveis pela nomeação dos membros da Repartição Central de Polícia e da Casa de Detenção.

Além disso, o chefe de polícia organizava os municípios em distritos policiais, podendo cria-los ou extingui-los e publicava as estatísticas criminais. No que diz respeito às atividades relacionadas à manutenção da ordem pública, competia à Chefia de Polícia todas as tarefas de investigação, conceder mandado de busca e de apreensão, inspecionar espetáculos e teatros públicos e, de forma bastante abrangente, segundo a lei $\mathrm{n}^{\mathrm{o}} 310$, "9. Velar e providenciar na forma da lei sobre tudo o que pertencer à prevenção dos delitos e à manutenção da segurança e tranquilidade pública”.

Já os delegados não precisavam ser formados em direito naquele momento, embora houvesse indicação na lei para que os da capital assim o fossem. Eles prestavam juramento perante o chefe de polícia ou o juiz de direito e tinham, dentre suas principais atribuições, as de "velar pelos bons costumes e moralidade pública, reprimindo o jogo e exercendo outras atribuições neste ramo de polícia" e "prender criminosos em flagrante delito e logo passa-los à jurisdição da autoridade competente".

Esses poderes atribuídos a chefes de polícia e a delegados eram fixados por legislações estaduais, como se vê. No Rio de Janeiro, por exemplo, segundo o regulamento 6.440, de 1907, cabia à polícia “XX - Ter sob sua vigilância as prostitutas escandalosas, providenciando contra ellas, sem prejuízo do processo judicial competente, da forma que julgar mais conveniente ao bem estar da população e á moralidade pública; XXII- Dar destino aos loucos e enfermos encontrados nas ruas, bem como aos menores e vadios e abandonados e aos 
mendigos". Ainda, "Si o interior da casa for accessivel a pessoas extranhas (villas, hospedarias etc) a intervenção, no sentido da segurança de todos, é legítima”. Apesar das diferentes previsões legais, tratava-se mais ou menos de uma tarefa comum desempenhada por todas essas forças: organização das cidades e da circulação de pessoas.

Em 1909, foi criada, em Pernambuco, a Segurança Noturna, uma guarda privada, composta de dez homens, subordinada ao chefe de polícia, com a finalidade de auxiliar o policiamento urbano e, em 1918, o Corpo de Segurança, Investigação e Captura, também destinado a auxiliar em investigações e vigilância, ambas as forças subordinadas ao chefe de polícia.

Em nível municipal, a Guarda Municipal do Recife foi criada pelo Decreto Lei no 3, de 22 de fevereiro de 1893. A lei foi assinada pelo então prefeito Manoel Pinto Damasco e dois dias depois publicada no Diário Oficial.

Esse era o quadro organizacional de polícias em Pernambuco nos anos pesquisados. Estarei muitas vezes me referindo, nas próximas páginas, a agentes ligados a todas essas forças e, portanto, durante o trabalho, evitarei falar em policial de forma genérica, lembrando sempre a que força eles estavam ligados quando isso for necessário.

\subsection{UMA POLÍCIA AMBIVALENTE: DE ESPAÇO DE RESOLUÇÃO DE CONFLITOS A UMA ATUAÇÃO TRUCULENTA E INEFICAZ}

No dia 31 de janeiro de 1926, uma mulher de nome Luiza Maria de F. encaminhou ao Chefe de polícia, Eurico de Souza Leão, uma carta suplicando-lhe que soltasse o seu filho Francisco Porphirio, preso, segundo ela, injustamente, por uma falsa acusação de defloramento feita "por um tal de Joel”. Segundo a Sra. Luiza, a vítima era uma criada de Joel e teria sido por ele deflorada. Porém, o verdadeiro deflorador mantinha relações escusas com o juiz do caso, agradando-lhe com presentes e, ainda, ordenado à polícia castigar a moça e a mandado embora, porque, "V. S. sabe que o dinheiro compra tudo, até a própria polícia"98.

$\mathrm{O}$ caso do qual parto nos remete a diversas problemáticas que tentarei tratar nas próximas linhas relativas a algumas características das forças policiais no início da República: 1) a grande autoridade exercida pelo chefe de polícia, 2) a dimensão de uma justiça policial informal vivenciada, sobretudo, entre as classes populares, com ou sem a anuência e desejo de seus destinatários 3) a baixa profissionalização de seus membros e 4) a desconfiança da sociedade em relação à organização, já que o dinheiro tudo poderia comprar, "até a polícia".

\footnotetext{
${ }^{98}$ APEJE, Fundo SSP, livro 467, Relatórios de delegados e subdelegados de polícia, $1^{\text {a }}$ Delegacia da Capital,
} 1926. 
Primeiramente, como dito, o chefe de polícia era a autoridade local responsável pela execução da política de segurança dos estados, mas também uma instância à qual recorriam $\operatorname{presos}^{99}$ ou seus familiares demandando liberdade, requerendo melhor tratamento no presídio ou mesmo a agilização de processos criminais. Paralelamente a isso, Chefia de Polícia também era procurada por comerciantes em busca de autorização para funcionamento de seus estabelecimentos, categorias profissionais que se sentiam ofendidas por notícias de jornal, moradores de bairros populares no Recife que pediam a atuação policial no combate à criminalidade, dentre tantas outras questões.

Esse era, portanto, um cargo muito estratégico, que dava ao seu titular uma grande visibilidade e, ainda, um importante impulso à carreira jurídica, o que explica o fato de muitos ministros do STF terem sido chefes de polícia e de muitos destes terem se tornado juízes ou políticos ao longo de suas carreiras ${ }^{100}$. Também não custa lembrar que, por se tratar de um cargo de confiança do Governador, aqueles que desempenhavam a função de Chefia de Polícia eram, em regra, bem relacionados politicamente, o que aumentava a chance de angariarem outros cargos também de confiança.

Sobre o segundo dos aspectos antes mencionados, o chefe de polícia e seus subordinados que coordenavam as atividades nas delegacias - delegados e subdelegados eram procurados por vários cidadãos para a resolução dos mais diversos problemas, jurídicos ou não, criminais ou não, fazendo da polícia uma organização realmente presente na vida da população mais pobre das cidades.

Marcos Bretas, em um estudo sobre práticas informais de resolução de conflitos em delegacias do Rio de Janeiro, no início do século XX, concluiu que a polícia agia como um “juiz sem direito a recurso. Para todos aqueles sem os recursos para recorrer à intervenção do estado, a polícia tornou-se o único estado possível"101.

Em um caso, que observei no arquivo e já mencionei no primeiro capítulo, a polícia civil aparece como uma instância para resolução de um problema de falta de pagamento de

\footnotetext{
${ }^{99}$ Era frequente nos arquivos da polícia civil a existência de cartas de presos encaminhadas à Chefia de Polícia, na qual pediam a esta autoridade que concedesse suas liberdades. Nos anexos 2 e 3, há uma Carta do preso correcional Benedicto Ribeiro de 1925 e outra de José Herminio dos Santos, vulgo "Bicudo", ambas encaminhadas ao Chefe de Polícia e nas quais pedem clemência para serem soltos. APEJE, Fundo SSP, livro 466. Relatórios de delegados e subdelegados de polícia, $1^{\mathrm{a}}$ Delegacia da Capital, 1925.

${ }^{100}$ Essa foi a trajetória de muitos ministros do Supremo, a exemplo, apenas a título ilustrativo, de Olegário Herculano de Aquino e Castro, João José de Andrade Pinto, Luiz Correa de Queiroz Barros, Henrique Pereira de Lucena (Barão de Lucena), Amphilophio Botelho Freire de Carvalho, Carolino de Leoni Ramos, Godofredo Xavier da Cunha e Pedro Augusto Carneiro Lessa.

${ }^{101}$ BRETAS, Marcos Luiz. O informal no formal: a justiça nas delegacias cariocas da República Velha. Discursos sediciosos. Rio de Janeiro: Instituto Carioca de Criminologia, ano 1, número 2, $2^{\circ}$ semestre, 1996, p. 221.
} 
aluguel. Em 13 de fevereiro de 1915, o Delegado Eneas de Lucena encaminhou um ofício ao chefe de polícia, tratando sobre uma reclamação feita por três indivíduos contra o subdelegado do $1^{\circ}$ distrito, Alcides Lopes de Oliveira, que os teria agredido. O delegado explicou o caso: tratava-se de um despejo frustrado contra sete portugueses que ocupavam uma casa na Rua da Moeda, centro do Recife, de propriedade de uma mulher de nome Dionisia Gomes do Carmo. A mulher teria procurado o subdelegado Alcides que, mesmo sabendo que despejo não era uma tarefa de sua atribuição, sabia que "a situação concreta demandava a ação da polícia”. Ocorre que os portugueses não teriam se conformado e, por uma discussão com sargentos do Corpo Policial deslocados para o serviço, foram presos por ordem do subdelegado e soltos apenas no dia seguinte ${ }^{102}$.

Outro campo privilegiado para se compreender o papel que a polícia exercia como uma instância de justiça mais próxima e acessível à população pobre e negra são os casos de defloramento. Pesquisando processos desse tipo de crime na cidade do Rio de Janeiro entre os anos de 1918 a 1940, Sueann Caulfield observa que, das mulheres que procuravam a autoridade policial, $20 \%$ eram pretas, $30 \%$, pardas e as brancas representavam $42 \%$. Os dois primeiros grupos de mulheres eram sobrerepresentados nesse tipo de caso, posto que, na época, as mulheres pretas e pardas correspondiam a $13 \%$ e a $18 \%$, respectivamente, da população ${ }^{103}$. Já no que toca à profissão - outro indicativo social e racial importante - a grande maioria delas era de empregadas domésticas (43\% das pardas e 52\% das pretas) e operárias, sendo que, dentre as brancas, a maioria (48\%) era "do lar", mulheres que não trabalhavam fora de casa.

Na polícia, famílias pobres e negras procuravam um espaço para discutir não só a violência contra suas filhas, mas também a manutenção da honra familiar e uma autoridade que obrigasse o agressor a se casar ${ }^{104}$. Em suma, a polícia faria as vezes de uma jurisdição familiar.

Bretas, no estudo antes mencionado, percebeu o mesmo padrão de comportamento da polícia e das famílias que a procuravam para resgatar a honra familiar no Rio de Janeiro. Um dos casos por ele tratado foi o de uma mãe que procurou a autoridade policial para submeter uma filha de treze anos a exames médicos, porque ela supostamente não era mais virgem, segundo boatos que corriam na vizinhança. Para Bretas, “a mãe buscava tranquilizar sua

${ }^{102}$ APEJE, Fundo SSP, livro 467, Relatórios de delegados e subdelegados de polícia, $1^{\text {a }}$ Delegacia da Capital, 1926.

${ }^{103}$ CAULFIELD, Sueann. Em defesa da honra: modernidade, moralidade e nação no Rio de Janeiro (19181940). Campinas: Editora Unicamp, 2000, p. 285.

104 Já que o casamento, no caso do defloramento, era uma hipótese de extinção de punibilidade, nos termos do artigo 276, parágrafo único do Código Penal de 1890. 
consciência através da polícia, considerando-a a agência apropriada para verificar a veracidade da acusação"105.

Nessas situações, existe uma polícia que se aproxima da comunidade como uma instância de resolução de conflitos, o que já nos leva a pensar que explicar a polícia e suas relações com a sociedade, no Brasil, apenas pela via da repressão policial não é suficiente. É preciso procurar entender por que essa polícia possuía, no período, uma legitimidade social que levava uma parte dos cidadãos - mormente a população negra e pobre das cidades - a ela confiar seus problemas.

Essas narrativas todas, frequentes nos estudos históricos sobre a polícia, remeteramme a uma obra fundamental sobre a polícia no Brasil, publicada na década de 1990. "Sua Excelência o Comissário", de Luciano Oliveira, é fruto de uma etnografia realizada pelo autor em delegacias de polícias de bairros periféricos da cidade do Recife no início dos anos 1980. No trabalho, Oliveira nos apresenta uma polícia proativa na resolução de conflitos familiares e pessoais de moradores desses bairros, porque, aparentemente, seria uma instância mais barata, próxima e menos burocratizada ${ }^{106}$ do que o próprio Poder Judiciário.

Embora não esteja falando da mesma polícia, posto se tratar de contextos históricos e sociais muito diversos, aparentemente essa organização se manteve como uma instância de solução de conflitos século XX adentro, e, quem sabe, é uma referência de acesso à justiça até hoje. Em bairros populares da cidade do Recife, continua não havendo uma rede descentralizada de defensorias, promotorias ou poder judiciário e, diante dos problemas cotidianos, as Delegacias podem ainda constituir o caminho mais evidente para um grande número de pessoas ${ }^{107}$.

O outro lado dessa justiça informal eram as decisões tomadas soberanamente pelas policiais de suspensão da própria lei. Prisões e espancamentos faziam parte do dia a dia do povo, tornando a polícia também um alvo constante de reclamações. Esse sentimento é frequente entre os usuários da polícia do período e demonstra a relação ambígua que essa

105 BRETAS, Marcos Luiz. O informal no formal: a justiça nas delegacias cariocas da República Velha. Discursos sediciosos. Rio de Janeiro: Instituto Carioca de Criminologia, ano 1, número 2, $2^{\circ}$ semestre, 1996, p. 219.

106 No trabalho, Oliveira apresenta diversos assuntos que eram apresentados, processados e julgados nas delegacias de polícia: agressões, ofensas morais, desordens, questões patrimoniais etc. Até mesmo o telefone da delegacia ficava disponível aos moradores da comunidade para ligações mais urgentes - ou que os Comissários julgassem importantes. OLIVEIRA, Luciano. Sua Excelência o Comissário e outros ensaios de sociologia jurídica. Rio de Janeiro: Letra Legal, 2004, p. 35.

${ }^{107}$ É possivelmente o caso da Lei Maria da Penha. Embora se trate de um tipo de violência vivenciado em todas as camadas da sociedade, são as famílias negras que protagonizam processos criminais nas Varas especializadas, conforme demonstra a pesquisa coordenada por Marília Montenegro, Fernanda Rosenblatt e Carolina Salazar, realizada através de um convênio da Universidade Católica de Pernambuco com o Conselho Nacional de Justiça. Ver: 
organização estabeleceu com a sociedade, sobretudo as pessoas mais pobres, constituindo fonte de confiança e desconfiança ao mesmo tempo. Neste sentido, reflete Eduardo Silva:

\begin{abstract}
A busca do estado protetor concentrava-se basicamente na ação dos aparelhos de polícia e de fiscalização, os pontos privilegiados de contato das classes populares com a cidadania. Uma relação tanto de fuga quanto de aproximação; um contato difícil, tenso, contraditório, não apenas porque os protagonistas se encontram em campos opostos, perseguidos e perseguidores. Mas também porque o guarda municipal encarregado da fiscalização ou a praça encarregada do policiamento das ruas pertenciam à mesma categoria social dos perseguidos - ambulantes, pequenos comerciantes, pescadores, prostitutas, capoeiras ${ }^{108}$.
\end{abstract}

Ao mesmo tempo em que a polícia era vista como próxima e capaz de resolver as intrigas do cotidiano popular, seu modo violento de atuar gerava revolta. Ainda no mesmo estudo, Eduardo Silva verificou que, entre as queixas realizadas pelo povo em um canal de reclamações do Jornal do Brasil, a polícia e as forças armadas estavam em primeiro lugar no ano de 1900, totalizando 20,8\% das falas de insatisfação. Em 1905, o saneamento básico passa à liderança das queixas, representando 20\%, mas em 1910, as polícias voltam ao primeiro lugar, totalizando $19,4 \%$ delas $^{109}$.

Encontrei, nos arquivos policiais do Recife, diversas situações que envolviam violência policial e a queixa feita por representantes do povo ou mesmo por outras autoridades, apesar de esse tipo de informação ser mais difícil de pesquisar em fontes oficiais, como pontei no capítulo 1.

No dia 19 de janeiro de 1915, um ofício do $1^{\circ}$ Delegado, Manoel Cysneiros, dirigido ao chefe de polícia, pedia providências a respeito de um caso de prisão e espancamento de um rapaz de nome Vitolino Pedro Correia da Silva por parte dos soldados Luiz Gonzaga de Oliveira e Silva, Antonio da Silva, Joao Francisco de oliveira, Mariano Ferreira de Lima e Francisco d'Almeida e um sargento, Manoel Joaquim dos Santos, todos do Corpo Policial ${ }^{110}$. O preso, além de violentado mais de uma vez, teria recebido banhos e passado a noite inteira com as vestes molhadas na cela da delegacia. O documento não informa se e quais providências foram tomadas.

Dias depois, uma mulher de nome Magnolia, qualificada como meretriz em um ofício do dia 23 de janeiro de 1915, procurou a Delegacia de Santo Amaro para falar com o chefe de

${ }^{108}$ SILVA, Eduardo. As queixas do povo. Rio de Janeiro: Paz e Terra, 1988, p. 35.

${ }^{109}$ SILVA, Eduardo. As queixas do povo. Rio de Janeiro: Paz e Terra, 1988, p. 107-109.

110 APEJE, Fundo SSP, livro 455, Livro de Ofícios de Delegados e Subdelegados da $1^{\text {a }}$ Delegacia de Polícia, 1915. 
polícia. Magnolia reportou uma queixa contra o Sargento Villar, do destacamento de Santo Antonio, que a teria maltratado com palavras indecorosas e, provavelmente, a forçado a fazer algo contra seu desejo, pois, segundo o termo de seu depoimento a "queixosa teria dito que não sabia o que um homem quer ao andar com uma mulher a força"111.

Em maio de 1916, a polícia teria novamente agido de forma truculenta junto a mulheres que se "portavam de modo indecoroso". Um ofício de um tenente-coronel do Corpo Policial dava conta de um comportamento não adequado de um corneteiro, Epiphanio Francisco de Souza, mas pedia providências sobre possíveis excessos promovidos pelos policiais civis envolvidos no caso. O delegado informou à Chefia de Polícia que teria prendido uma mulher de nome Brazilina, em razão de ela estar, junto a outras mulheres, se portando mal numa porta de escada à rua Estreita do Rozário. Epiphanio estava no colo de Brazilina e, ao ser admoestado por soldados do Corpo Policial, agiu de modo inconveniente, motivo pelo qual teria sido também preso. Ele teria também protestado contra a prisão de Brazilina, que só foi liberada no dia seguinte ${ }^{112}$. Aparentemente, na condução de Braziliana e Epiphanio, os agentes e subdelegado teriam agido violentamente.

A terceira característica antes mencionada dessas forças policiais, fossem civis ou militares, era a baixíssima profissionalização. Embora no início do século XX, algumas leis de reforma policial tenham procurado prever a criação de Escolas de Polícia, bem como estabelecer planos de cargo e de carreira, ainda era frequente o ingresso por meio do alistamento voluntário de membros das classes populares e a permanência na organização por prazo certo ou a critério da Chefia de Polícia. Por que tão precário vínculo poderia ser atraente? É difícil mencionar, mas, provavelmente, muitos indivíduos podiam estar em busca de patentes mais elevadas (quando havia possibilidade de progressão na carreira) ou mesmo de reconhecimento social, além de representar, bem ou mal, um vínculo formal de trabalho.

O baixo profissionalismo também ficava estampado na forma como os membros das forças policiais eram tratados e as obrigações que adquiriam. Como destacou Wellington Santos, os policiais precisavam constantemente dispor de seus próprios recursos para realizar a atividade de vigilância, como comprar suas roupas, seus fardamentos e até armamentos era uma exigência ${ }^{113}$.

\footnotetext{
${ }^{111}$ APEJE, Fundo SSP, livro 455, Livro de Ofícios de Delegados e Subdelegados da $1^{\text {a }}$ Delegacia de Polícia, 1915.

112 APEJE, Fundo SSP, livro 456, Livro de Ofícios de Delegados e Subdelegados da $1^{\text {a }}$ Delegacia de Polícia, 1916.

${ }^{113}$ No Regulamento do Corpo Policial do Estado de Pernambuco, de 1896, havia, no artigo $8^{\circ}$, uma previsão de desconto de 50 reis por dia do soldo de cada praça para pagar as despesas com dois fardamentos (um de gala e outro ordinário).
} 
No dia 8 de janeiro de 1915, escrivães das três delegacias distritais da cidade do Recife elaboraram um abaixo-assinado para o chefe de polícia, Joaquim Wanderley, solicitando aumento de suas remunerações (à época fixada em 40 passes) e um cartão para livre circulação nos trens e bondes da cidade. Eles explicavam a demanda lembrando que o salário que recebiam não era suficiente para executar as tarefas das delegacias e as diligências externas para as quais eram requisitados e, desse modo, eram obrigados a "gastar de seu dinheiro" para satisfazerem as exigências de uma emissão ${ }^{114}$.

Essa confusão entre o patrimônio particular e público marcou a formação de várias organizações estatais brasileiras e não apenas a polícia, como destacou Maria Sylvia de Carvalho Franco. Tratando da formação da burocracia ${ }^{115}$ na segunda metade do século XIX e pesquisando arquivos da Câmara municipal de Guaratinguetá, a autora verifica que a escassez de bens públicos é grande, gerando uma forte demanda de ajuda por parte dos cidadãos e dos funcionários públicos que, não raramente, cotizavam-se para fazer pequenas reformas ou obras públicas. Para ela, essa indistinção entre o patrimônio particular do funcionário e o bem público passa a ser realidade nos dois vetores, de modo a entender o funcionário que o dinheiro da administração também é seu ${ }^{116}$.

Da mesma forma, policiais que mantinham suas atividades com esforço próprio ou de particulares poderiam ser facilmente conduzidos a agir de acordo com seus interesses particulares ou aos daqueles que os financiavam. Bretas destaca que os praças, aqueles que faziam efetivo policiamento ostensivo, eram comumente tratados como corruptíveis e sujeitos aos caprichos políticos de autoridades locais, sendo ainda comuns os casos de corrupção, de suborno sobre criminosos e favorecimento pessoal e, assim, "de tudo isto, resultaria que a Polícia a quem incumbia ordenar, organizar e conhecer para disciplinar apresentava-se, ela própria, indisciplinada, desorganizada e desordenada" ${ }^{117}$.

\footnotetext{
${ }^{114}$ APEJE, Fundo SSP, livro 455, Livro de Ofícios de Delegados e Subdelegados da $1^{\text {a }}$ Delegacia de Polícia, 1915.

${ }^{115} \mathrm{O}$ conceito de burocracia racional-legal foi trabalhado por Max Weber como um tipo ideal que se alastrou nas sociedades modernas e que, estruturando a administração, apresenta as seguintes características: a) a existência de áreas de jurisdição fixas e oficiais ordenadas de acordo com regulamentos; b) a existência de hierarquia no quadro administrativo, com supervisão dos órgãos inferiores; c) a prevalência de documentos escritos d) a separação entre a esfera privada do funcionário e a esfera pública na qual exerce o seu cargo; e) a profissionalização e treinamento técnico do corpo de funcionários; f) o desempenho do cargo segundo regras gerais. WEBER, Max. Ensaios de sociologia. Rio de Janeiro: Zahar Editores,1963, p. 229-231. Esse tipo ideal, opõe-se à burocracia patrimonial ou ao patrimonialismo, expresso nas experiências apontadas por Maria Sylvia Franco.

${ }^{116}$ FRANCO, Maria Sylvia de Carvalho. Homens livres na ordem escravocrata. 4 ed. São Paulo: Editora UNESP, 1997, p. 131.

${ }^{117}$ MATOS, Ilmar Rohloff de; CARVALHO, Maria Alice R. de. A polícia e a força policial no Rio de Janeiro. Estudo das características histórico-sociais das instituições policiais brasileiras, militares e paramilitares, de suas origens até 1930. Rio de Janeiro: PUC, 1981, p. 133.
} 
No Relatório do Chefe de polícia de Pernambuco, Francisco Porphirio de Andrade Lima $^{118}$, em 1913, existe uma reclamação específica em relação ao cargo de subdelegado que, à época, não era remunerado. Segundo o chefe de polícia, os subdelegados assumiam essas funções com a finalidade de promover favores pessoais a indivíduos poderosos, que os pagavam para aplicar a lei da forma como lhes conviesse. "Se desculpam sempre com a justa alegação de precisarem ganhar a vida e que só desempenham o cargo para fazer favor"119, anota o Porphirio, reclamando ao governo a extinção desse cargo e a criação de uma carreira remunerada de Comissários de Polícia.

Curiosamente, a informação de que as pessoas assumiam o cargo de subdelegado para fazer favor está escrita de modo natural no relatório, sem arrodeios, sugerindo se tratar de um fato de conhecimento geral.

Em 1919, verifiquei ainda ter um inquérito sido aberto pelo Delegado da $1^{\text {a }}$ Delegacia da Capital, Anulpho Lins e Silva, para investigar um suposto suborno de quinhentos mil reis pago a um escrivão da subdelegacia de Santo Antonio, Eustachio de Macedo França, com o intuito de liberar David Campos, um homem acusado de ter matado José Martins Ribeiro no dia 17 de julho daquele ano. A transação teria sido facilitada pelo cunhado de David, Mamede Lins, amigo do escrivão. Ao longo das investigações, foram ouvidas dezesseis pessoas e o delegado concluiu não ter qualquer prova do envolvimento de Eustachio no caso.

Verdadeiros ou não os fatos alegados, como disse a Dona Luiza Maria de F., "o dinheiro compra tudo, até a própria polícia”.

Essas forças iniciam, assim, o século XX, em franca crise de reconhecimento social. Como dito acima, o policiamento de rua era alvo constante de críticas feitas através dos diversos canais de comunicação da sociedade, conforme relatam a maior parte dos estudos históricos sobre a polícia. Tanto a violência como a baixa eficiência do policiamento são aspectos mencionados na imprensa, em músicas, em charges e, diante desse quadro, as cúpulas das polícias civil e militar empreenderam um franco esforço de melhorar a imagem que aquelas agências possuíam. No próximo tópico, o teor e o sentido dessas mudanças modernizadoras serão debatidos.

\footnotetext{
118 Francisco Porfírio de Andrade Lima nasceu em 1863 e faleceu em 1920. Era conhecido como "Chico Porfírio". Foi Chefe de Polícia em Pernambuco, cargo que hoje é comparado ao atual Secretário da Defesa Social do Estado. Quando faleceu, era Juiz de Direito da Comarca de Timbaúba.

${ }^{119}$ APEJE, Fundo Secretaria Geral, Livro 190. Relatório da Chefia de Polícia, 1914.
} 


\subsection{DO “CAPOEIRA DE FARDA" A SHERLOCK HOLMES: UMA POLÍCIA QUE SE PRETENDE MODERNA}

A passagem do século XIX para o século XX é um período, como já fiz referência no capitulo anterior, de grande euforia e desenvolvimento de um sonho civilizatório que ocupou a elite intelectual brasileira e também seus quadros institucionais. A polícia foi tomada por essa onda e também quis se tornar moderna. O que, afinal, essas forças entendiam por modernidade?

Uma fonte privilegiada para responder a essa pergunta são as revistas policiais surgidas no início do século passado. As revistas já eram, em si, um empenho da polícia, tanto a civil como a militar, de se tornar mais transparente, parecer mais científica e demonstrar os seus avanços técnicos. Tanto é assim que, no Distrito Federal, duas publicações importantes surgiram no período: a Revista Policial (1903-1904), da Brigada Militar e o Boletim Policial (1907-1917), da Polícia Civil, ambas destinadas ao público policial, mas, também à sociedade em geral e a atores do sistema de justiça criminal como médicos, peritos e juristas.

Marcos Bretas analisou os dois anos de publicação da Revista Policial e verificou que o aprimoramento da atividade e o resgate da estima da organização era uma preocupação central de seus redatores (na maioria tenentes, alferes e coronéis). Como ele destaca:

Havia também um esforço evidente de definir as características desejáveis
numa boa polícia, seja pela definição de políticas de ação, seja pela instrução
que se pretendia passar para os praças. A formação dos praças é um tema
permanente, no qual a oficialidade não enfrenta grandes dissensos sobre o
que se deseja: obediência, moralidade e boa aparência são os aspectos
sempre enfatizados ${ }^{120}$.

Nessa revista, que durou muito pouco tempo, um tema também recorrente eram as táticas de investigação mais modernas, ligadas a uma polícia científica. Curioso, como comenta Bretas, é que a revista era da polícia militar, responsável pelo policiamento ostensivo e não pela investigação. Porém, nada parecia mais modernizador do que uma polícia amparada na legitimidade da ciência e conhecedora das novas técnicas empregas mundo afora. Enfim,

[...] a polícia estava inserida no pensamento brasileiro da belle époque, que tinha seus olhos voltados para a Europa, e especialmente para Paris. Não é à toa que, a primeira informação internacional, já no segundo número da

${ }^{120}$ BRETAS, Marcos Luiz. Revista Policial: formas de divulgação das polícias no Rio de Janeiro de 1903. História Social, n. 16, primeiro semestre de 2009, p. 94 . 
Revista, chamava-se "A Polícia de Paris e a Nossa", de autoria do major Cruz Sobrinho, e abria com a opinião do ex-chefe de polícia, Brasil Silvado, que a considerava "a primeira do mundo, quer pela habilidade, presteza e perspicácia que patenteia na descoberta dos crimes praticados, quer por sua organização geral" 121 .

Sem dúvidas mais duradoura e influente, a publicação da Polícia Civil do Distrito Federal, o Boletim Policial, é um prato cheio para compreender o emprenho civilizatório dessas forças. Pedro Tórtima avaliou as edições do Boletim e destacou a fortíssima inspiração positivista e especialmente "lombrosiana" nos mais diversos assuntos tratados, especialmente os relativos à investigação e à identificação criminal $^{122}$. A bertillonagem ${ }^{123}$, a datiloscopia e a identificação fotográfica, novidades à época, eram abordados com euforia. Até mesmo figuras literárias como Sherlock Holmes eram citadas nos escritos ${ }^{124}$ como exemplo de uma polícia ideal.

Eu consultei os quatro primeiros anos do Boletim, correspondente aos volumes 1 a 10 e publicados entre 1907 e 1910. Pretendia chegar um pouco mais perto desses discursos, conhecer como se organizava uma revista policial, quem escrevia nelas e quais eram as prioridades em termos de temática.

Eram praticamente peritos, delegados e o próprio chefe de polícia quem comumente escrevia no periódico, não havendo participação de policiais civis de mais baixa hierarquia como comissários ou escrivães. Percebi que com o Boletim se dava a mesma situação verificada por Bretas em relação à Revista Policial: soldados e praças não escreviam na revista; como, por certo, tampouco a liam.

O Boletim veicula muitas temáticas, envolvendo artigos de opinião, traduções de textos científicos, publicação de estudos de criminólogos locais, divulgação de ações da polícia civil, apresentação de perícias e estatísticas criminais. Em cada volume, também, a publicação faz referência a outros periódicos que citam o Boletim Policial, demonstrando o prestígio deste.

\footnotetext{
121 BRETAS, Marcos Luiz. Revista Policial: formas de divulgação das polícias no Rio de Janeiro de 1903. História Social, n. 16, primeiro semestre de 2009, p. 100.

122 TÓRTIMA, Pedro. Crime e castigo para além do Equador. Belo Horizonte: Inédita, 2002.

123 Técnica de identificação criminal baseada nas medidas do corpo - antropometria - criada pelo policial francês Alphonse Bertillon, que chegou a chefiar o Serviço de Identificação da Polícia de Paris. Bertillon não pretendia reunir as medidas corporais como causa do delito, fugindo, assim, ao determinismo biológico da Escola Positiva Italiana, mas, sem dúvidas, todas as técnicas de identificação surgiram em um contexto de controle de circulação das pessoas nas cidades, de modo que a identificação chegou primeiro para os desviantes e apenas depois passa a se tornar um processo generalizado para todos os cidadãos. Neste sentido, ver: GALEANO, Diego. Identidade cifrada no corpo: o bertillonnage e o Gabinete Antropométrico na Polícia do Rio de Janeiro, 1894-1903. Boletim do Museu Paraense Emílio Goeldi. Ciências Humanas, v. 7, n. 3, p. 721-742, set-dez, 2012, p. 724.

${ }^{124}$ TÓRTIMA, Pedro. Crime e castigo para além do Equador. Belo Horizonte: Inédita, 2002, p. 112.
} 
Dentre as várias temáticas, chamou a minha atenção um artigo sobre abordagem nãoviolenta $^{125}$, método mais condizente com o que eles chamavam de "nova criminalidade". Também verifiquei, em algumas edições, sentenças criminais publicadas na íntegra em casos de jogo do bicho e vadiagem, apontando para a atuação correta das polícias em buscar eliminar esses germens - conforme a linguagem fortemente biológica da época -. Há ainda a publicação de perícias físicas e psíquicas completas, ressaltando o grande avanço da medicina e da antropologia criminal e, em todos os números, as estatísticas criminais do período. Estes dados são relativos às prisões realizadas pela polícia e ao recolhimento às prisões Correcionais de Dois Rios, ao Asylo de Mendicidade e à Casa de Detenção, sendo expostos de acordo com o sexo, a cor, a escolaridade, a nacionalidade e a idade do preso, um detalhamento que, aliás, não encontrei nos relatórios da Chefia de Polícia pernambucana.

De um modo geral, pude perceber, durante a pesquisa, uma polícia que ansiava por mudanças e das mais diversas ordens: no comportamento, no fardamento, na postura, na forma de andar, no ingresso e na progressão da carreira, na formação policial, enfim, em tudo a polícia parecia precisar se transformar para acompanhar aquele sonho civilizatório. Muito curiosas são, como destacado por Tórtima, as citações frequentes a contos de Conan Doyle, como se aqueles redatores sonhassem com uma realidade que imitasse a ficção. Sherlock Holmes era um modelo de policial a ser alcançado: inteligente, sagaz e eficiente, os atributos por que se ansiava.

O horizonte daqueles agentes era, de fato, as polícias europeias, notadamente a inglesa e a francesa e civilizar-se, portanto, era europeizar-se; e mais do que apenas mudanças de ordem organizacional e técnica, a polícia pretendia ter uma nova imagem, parecer-se com o policial europeu e, neste sentido, embranquecer-se.

Embora o debate racial não apareça explicitamente nas publicações por mim analisadas, ele estava contido nos referenciais teóricos de muitos dos textos - as teorias criminológicas positivistas - e também na concepção guardada pela polícia na época de que o "capoeira de farda" precisava ser superado enquanto padrão de policiamento. Uma charge de J. Carlos (anexo 4), de 1908, comentada por Bretas expõe com muita clareza esse ponto.

Na imagem, o "polícia" é um homem negro, com traços faciais bem definidos, que se apresenta como um "cabra veio", um "capoeira de farda". Em outras palavras, um negro de farda. Já o "civil" - portanto, um policial não militar - é branco e o retrato da civilização

${ }^{125}$ REPÚBLICA FEDERATIVA DOS E. U. DO BRAZIL.POLÍCIA CIVIL DO DISTRITO FEDERAL. Boletim policial, Ano I, Volume 5, 1907. 
europeia, ideal para um Rio de Janeiro em pleno progresso. Era mesmo a superação do "capoeira" por Sherlock Holmes.

O surgimento da Guarda Civil no Rio de Janeiro, em 1905, esteve diretamente ligado a essa demanda de superação do policiamento realizado pelos "capoeiras de farda", pois a atuação da Polícia Militar nos primeiros anos da República em incidentes como a Revolta da Vacina pôs essa força definitivamente em xeque, levando à criação de uma polícia preventiva não militarizada, a qual era constantemente elogiada nos meios de comunicação em detrimento da Brigada Militar ${ }^{126}$. Uma fotografia da Guarda, de 1907, constante no anexo 5, mostra bem a composição racial daquela força policial, sugerindo que a modernização passaria, de fato, pelo branqueamento da polícia que, até então, em seus estratos mais baixos, era majoritariamente negra.

Sobre esse aspecto, Dora Lúcia Bertúlio pondera que, após a abolição, os trabalhos formais foram reservados a brancos pobres e imigrantes, enquanto aos libertos se restaram os informas (biscateiros, carregadores, domésticos, sapateiros, jornaleiros etc) e, curiosamente, a atividade policial que, "devido aos baixos salários, foram preenchidos os batalhões com negros que significativamente não ultrapassavam os escalões do serviço. O oficialato sempre foi reservado aos brancos" $" 127$.

Em Pernambuco, o surgimento de uma Guarda Civil também estava envolto em um discurso sobre policiar melhor para o novo público que circulava nas cidades. No Relatório Anual do ano de 1914, emitido pela Repartição Central de Polícia à Secretaria de Justiça de Pernambuco, o Chefe de polícia, Joaquim Maurício Wanderley, afirma que

\begin{abstract}
Nesta cidade, sede de governo, porto comercial importante, ponto de convivência de estrangeiros, ligada por estrada de ferro aos Estados vizinhos, a nossa praça da Força Pública, armada a sabre, sem compostura e sem a imprescindível instrução, não corresponde absolutamente às exigências do nivel social hoje alcançado. Para as artérias mais movimentadas, para os theatros, cafés, jardins, festejos e ajuntamentos, um corpo de policiais mais polidos e convenientemente instruídos, é necessário ${ }^{128}$.
\end{abstract}

A polícia militar pernambucana, segundo a Chefia de Polícia, não tinha "compostura" e precisava ser substituída por um corpo mais "polido e instruído" para que pudesse fazer um

\footnotetext{
${ }^{126}$ BRETAS, Marcos Luiz. Ordem na cidade: o exercício cotidiano da autoridade policial no Rio de Janeiro: 1907-1930. Rio de Janeiro: Rocco, 1997, p. 46.

${ }^{127}$ BERTÚLIO, Dora Lúcia. Direito e relações raciais: uma introdução crítica ao racismo. Dissertação de mestrado. Programa de Pós-Graduação em Direito. UFSC. 1989, p. 106.

${ }^{128}$ APEJE, Fundo Secretaria Geral, Livro 190, Relatório da Chefia de Polícia, 1914, p. 8.
} 
trabalho à altura do seu público, permeado de estrangeiros de pessoas de nível social mais avançado.

Bretas, analisando a Revista Policial, também verificou uma preocupação com a melhoria da postura dos seus praças e, aqui, conseguimos contextualizar novamente a charge de J. Carlos, antes mencionada. À medida do possível, os soldados e praças deveriam caminhar ao ritmo de uma marcha, evitando gingados e o andar "malandro", certamente hábitos ligados à origem social desses agentes; ao mesmo tempo, deveriam se distanciar das contendas dos bairros e se reservarem à disciplina da caserna; os policiais precisavam abandonar de uma vez por todas o uso de álcool e parar de conversar informalmente com pessoas nas ruas ${ }^{129}$.

No mesmo sentido, no volume 6 do Boletim Policial, um artigo assinado por O. B., cuja identidade não consegui verificar, tratava das mudanças civilizatórias da polícia. Ele inicia o artigo comentando ter visto pela primeira vez passar nas cidades um automóvel ônibus adquirido para o transporte da polícia civil. O autor lembra que a polícia de "antes" era extremamente violenta, truculenta, tendo protagonizado casos de socos e pontapés em bêbados prostrados nas ruas. Mas essa realidade teria mudado. Referindo-se ao antigo policial como 'morcego', o autor critica a polícia com elementos que antepunham a civilidade branca à incivilidade negra dos "capoeiras":

Felizmente, o 'morcego' desapareceu. Desapareceu, como as vacas leiteiras, como o tipo clássico do capoeira de profissão, como os anúncios de escravos fugidos, como os mendigos chegados, e como tantas cousas e pessoa que eram partes integrantes da vida do velho Rio de Janeiro ${ }^{130}$.

Finalmente, e concluindo, ele diz que a polícia civilizada é digna da nova faceta do crime na "era hypercivilizada": mais "smart, up to date, digna dos cavalheiros da mais digna sociedade" $" 131$.

Como se vê, as críticas às forças militarizadas da polícia estivam ligadas, muitas vezes, ao seu componente racial, embora, em outros momentos, o fato de ser uma instituição militar, em si, parecesse o verdadeiro inconveniente. Na Conferência Judiciário Policial de 1917, o desembargador Geminiano da França falava sobre os malefícios da militarização da

\footnotetext{
${ }^{129}$ BRETAS, Marcos Luiz. Revista Policial: formas de divulgação das polícias no Rio de Janeiro de 1903. História Social, n. 16, primeiro semestre de 2009, p. 95-96.

${ }^{130}$ REPÚBLICA FEDERATIVA DOS E. U. DO BRAZIL.POLÍCIA CIVIL DO DISTRITO FEDERAL. Boletim policial, Ano I, Volume 6, 1907, p. 16

${ }^{131}$ REPÚBLICA FEDERATIVA DOS E. U. DO BRAZIL.POLÍCIA CIVIL DO DISTRITO FEDERAL. Boletim policial, Ano I, Volume 6, 1907, p. 16
} 
Brigada Militar: "Não há hoje quem não reconheça os inconvenientes do policiamento militar. Jungido à disciplina militar, tem o soldado o dever de respeitar aos seus superiores hierárquicos, o que constitui um obstáculo constante para o desempenho de suas funções." 132

De toda forma, a polícia pretendia mudar. Outro símbolo dessas tentativas de transformação das polícias foram as reformas empreendidas no período. A reforma policial executada em 1907 pelo chefe de polícia do Rio de Janeiro, Alfredo Pinto ${ }^{133}$, é bem representativa. No texto que abre a primeira edição da revista criada sob sua gestão, o Boletim Policial, Pinto apresenta diversos desafios a serem enfrentados pela organização que chefiava, no intuito de se igualar às melhores polícias do mundo. O texto é permeado de elementos de política criminal típicos do positivismo criminológico - identificando nos indivíduos a origem do delito e propondo políticas de identificação, recolhimento e tratamento individualizado sobre eles -, embora Pinto não cite nenhuma das referências teóricas das escolas italiana ou francesa ${ }^{134}$.

Para ele, alguns pontos eram cruciais para o avanço: a criação de centros de formação profissional e educacional, a exemplo das workhouses inglesas, sobretudo voltados aos menores e aos vagabundos; a criação de procedimentos penais mais simplificados, a fim de dar conta da grande demanda de casos, sobretudo os relativos às contravenções; a autonomia das polícias; a criação de planos de cargo e de carreira e a autonomia da polícia em relação ao governo.

De fato, a partir de 1907, Alfredo Pinto pôs em prática várias dessas propostas: aprovou um plano de cargo e de carreiras para a polícia, adotou técnicas de investigação novas como o reconhecimento fotográfico e por impressões digitais, criou a Escola de Polícia, criou o Asylo de Mendicidade, uma forma, segundo o discurso da época, de lidar com a menoridade abandonada educando e não apenas reprimindo, pois, segundo Pinto, "a escola e o trabalho são elementos poderosos de eliminação da criminalidade" ${ }^{135}$, criou uma divisão de estatística (o Gabinete de Investigação e Estatístiva) e a revista científica, o Boletim Policial.

Na mesma toada, em Pernambuco, o Regulamento do Serviço de Identificação previu, no artigo 2, alínea $h$, a publicação de um boletim policial, para, com isso, aprimorar os dados

\footnotetext{
132 FRANÇA, Geminiano da. These II. Seção I. Annaes da Conferência Judiciária-Policial de 1917. Rio de Janeiro: Imprensa Nacional, 1918, p. 21.

${ }^{133}$ Alfredo Pinto foi nomeado por Afonso Pena. Era de Minas Gerais e já tinha sido deputado, tendo trabalhado da proposição e aprovação da Lei $n^{\circ} 698$, que permitia aos delegados e subdelegados instaurarem ex-officio processos no caso de algumas contravenções.

${ }_{134}$ REPÚBLICA FEDERATIVA DOS E. U. DO BRAZIL.POLÍCIA CIVIL DO DISTRITO FEDERAL. Boletim policial, Ano I, Volume 1, 1907, p. 2-7.

135 REPÚBLICA FEDERATIVA DOS E. U. DO BRAZIL.POLÍCIA CIVIL DO DISTRITO FEDERAL. Boletim policial, Ano I, Volume 2, 1907, p. 13.
} 
estatísticos, formar seus membros e aperfeiçoar os métodos de investigação. Porém, essa publicação não existiu por falta de verbas, conforme destacado no Relatório da Chefia de Polícia publicado de 1914, e a polícia pernambucana divulgava anualmente as suas estatísticas nesses relatórios, nem sempre com a mesma profundidade e fragmentação das variáveis ${ }^{136}$.

De se notar que, em torno das estatísticas, há uma crença de cientificidade e de objetividade que também é muito própria ao período. A polícia civil do Distrito Federal, assim como a de Pernambuco, contavam com um Gabinete de Estatística e Investigação, divisões que representariam esse empenho modernizador.

Um último ponto que destaco nesses projetos de mudança diz respeito à polícia e a sua relação com os diferentes tipos de ilegalidades. Como afirmado acima, Pinto propôs uma reforma policial que contemplasse a criação de procedimentos mais simplificados para lidar com as contravenções.

Existia uma narrativa, como dito acima, de que "a nova criminalidade" exigiria "uma nova polícia". Essa "nova criminalidade" da sociedade "hypercivilizada" demandaria uma polícia ostensiva menos violenta e truculenta e uma polícia administrativa mais científica, que pudesse proceder a diligências investigativas robustas e criteriosas.

Porém, nas entrelinhas, a revista deixa evidente que haveria uma parcela de desviantes a quem todo esse aparato novo não se destinaria: os contraventores.

Em diversos números que analisei, o Boletim faz discussões sobre a problemática da morosidade dos processos de contravenção penal, sobretudo de vadiagem e jogo do bicho. Aqui, a opinião policial pretende gerar interferência a nível legislativo, dando a revista espaço para deputados e debates sobre projetos de lei.

Os processos de contravenção, porque simples e de menor complexidade, demandariam um procedimento célere e com grande protagonismo policial. Pinto, como grande defensor dessa ideia, tinha, como deputado, proposto um projeto que desencadeou na criação da Lei no 648, em 1899, que dispôs sobre a possibilidade de delegados e subdelegados instaurarem ex-officio processos em casos de contravenção de jogo do bicho e vadiagem. Segundo a lei, após a instauração e instrução pelos policiais, o processo seria encaminhado à Pretoria, que procederia ao julgamento.

Mas o Boletim, em praticamente todos os números de 1907 a 1910, faz uma verdadeira campanha pela criação dos chamados juízos correcionais e pela ampliação da competência dos delegados e subdelegados. A ideia era a de que todas as contravenções

${ }^{136}$ APEJE, Fundo Secretaria de Justiça, Livro 190, Relatório da Chefia de Polícia, 1914. 
fossem processadas ex-officio pelos delegados e que o processo, depois de instruído, fosse encaminhado a um juiz com competência apenas para julgar esse tipo de caso. Para cada distrito policial haveria um juiz correcional.

O projeto de lei com esse teor foi proposto pelo deputado José Cândido de Albuquerque Mello Mattos ${ }^{137}$, em uma sessão de 15 de junho de 1907, e foi por ele defendido por contemplar celeridade, prontidão na resposta e justiça na aplicação da lei. Segundo ainda os redatores do Boletim, os juízos correcionais eram uma realidade de países como a França e a Inglaterra. No número 1 do Ano II do Boletim, a defesa do projeto de Mello Mattos é feita em diversas páginas pelo então Chefe de polícia Alfredo Pinto, que insiste no fato de que "contravenções não são delitos", mas atos antissociais que, independente de culpa ou de dolo, devem ser proibidos e reprimidos pela segurança, saúde, higiene e decoro público, tratando-se, portanto, primordialmente de um problema do poder de polícia $^{138}$. Ser contraventor era um estado e não uma conduta, afinal, nem dolo e culpa precisariam ser provados.

A ideia por trás desse projeto é a de que as contravenções são desvios simples e que os desordeiros seriam conhecidos pelos policiais, razão pela qual o procedimento deveria ser instaurado de ofício por delegados. Como lembra Souza, "para o policial, o sistema judiciário, distante, caro e moroso, com suas regras formais e com o seu acento na defesa dos direitos, não seria suficientemente eficaz no combate à criminalidade"139

Porém, essa não era uma discussão apenas técnica. A autonomia desejada pela polícia, por alguns deputados e juristas para o processamento dos contraventores era uma reivindicação que possui um sentido muito mais profundo para o funcionamento do sistema de justiça criminal. Tratava-se de oficializar uma prática já existente: contraventores já eram um caso de polícia.

Observando as estatísticas oficiais de crimes e de contravenções em 1907, no Distrito Federal, parece-me evidente essa situação:

Tabela 4: Estatística Criminal - Contravenções $-1^{\circ}$ trimestre de 1907 - Distrito Federal ${ }^{140}$

\footnotetext{
137 Idealizador também do primeiro Código de Menores do Brasil, promulgado em 1927. A repressão aos contraventores estava amparada em um discurso correcionalista que pretendia destinar essa massa de "desvalidos" ao trabalho e ao estudo. O mesmo que ampara a criação de uma justiça juvenil no Brasil.

138 REPÚBLICA FEDERATIVA DOS E. U. DO BRAZIL.POLÍCIA CIVIL DO DISTRITO FEDERAL. Boletim policial, Ano II, Volume 1, 1908, p. 17.

${ }^{139}$ SOUZA, Luís Antônio Francisco de. Lei, cotidiano e cidade: polícia civil e práticas policiais na São Paulo republicana (1889-1930). São Paulo: IBCCRIM, 2009, p. 48.

${ }^{140}$ Fonte: REPÚBLICA FEDERATIVA DOS E. U. DO BRAZIL.POLÍCIA CIVIL DO DISTRITO FEDERAL. Boletim policial, Ano I, Volume 2, 1907.
} 


\begin{tabular}{lccccc}
\hline & Total & Nacional & Estrangeiro & Branco & Negro \\
\hline Homem & 651 & 307 & 344 & 478 & 319 \\
Mulher & 238 & 220 & 18 & 45 & 191 \\
\hline
\end{tabular}

No que diz respeito somente às contravenções, verifiquei que os homens estrangeiros eram um alvo frequente das abordagens policiais. Eles eram de nacionalidade principalmente portuguesa, italiana e espanhola (neste ordem) ${ }^{141}$ sendo, em sua maioria, homens brancos. Já os nacionais, devem responder à maioria dos 319 negros presos por essa razão. As mulheres negras, por sua vez, são os alvos preferenciais da detenção por contravenção, havendo, como demonstrarei a seguir, uma predominância de abordagem por vadiagem. Assim, poderia dizer que a imagem do contraventor, no Rio de Janeiro, é de um homem branco estrangeiro, de um homem nacional negro e de uma mulher negra.

Quando analisei a composição racial e sexual das prisões por crimes, a realidade é bem diferente das contravenções:

Tabela 5: Estatística Criminal - 2 ${ }^{\circ}$ Trimestre de 1907 - Polícia Civil do DF DF $^{142}$

\begin{tabular}{lccccc}
\hline & Total & Homem & Mulher & Branco & Negro \\
\hline Crimes & 426 & 415 & 11 & 294 & 133 \\
Contravenções & 964 & 749 & 215 & 447 & 515 \\
\hline
\end{tabular}

Primeiramente, destaco que as prisões por contravenção correspondem a mais que o dobro das prisões por crimes (em sua maioria contra o patrimônio e contra a pessoa). Assim, parte relevante da atividade policial se resumia a lidar com esses contraventores, o que explica o protagonismo que essas forças reivindicavam para si.

Assim, aos contraventores, reservar-se-ia um processo mais simplificado, iniciado pela polícia, no qual sequer precisava ser demonstrada a culpa ou o dolo do agente. Em outros termos, pode-se dizer que seria um processo penal do autor. Já para a nova criminalidade "hypercivilizada", estava guardado um processo penal moderno, contando com uma investigação científica e cautelosa, com os métodos mais inovadores e precisos, um processo

\footnotetext{
${ }^{141} \mathrm{O}$ dado relativo à prisão dos contraventores por nacionalidade aparece no Número 12 do Boletim Policial, do ano de 1910. Embora não seja o mesmo ano das estatísticas acima referidas, nota-se um padrão ao longo dos anos que nos permite deduzir serem os brancos estrangeiros presos dessas mesmas nacionalidades. REPÚBLICA FEDERATIVA DOS E. U. DO BRAZIL.POLÍCIA CIVIL DO DISTRITO FEDERAL. Boletim policial, Ano III, Volume 12, 1910, p. 79.

${ }^{142}$ Fonte: REPÚBLICA FEDERATIVA DOS E. U. DO BRAZIL.POLÍCIA CIVIL DO DISTRITO FEDERAL. Boletim policial, Ano I, Volume 3, 1907.
} 
penal do fato. Esse argumento será aprofundado nos próximos capítulos, porque é central no argumento aqui construído sobre a soberania policial.

Bom, apesar de todas essas novidades, os esforços de modernização não alteraram substancialmente as práticas policiais no início da República que, como visto, continuava a ser vista como corrupta, truculenta e ineficiente. Uma possível explicação para essa dificuldade de mudança no padrão das práticas está no fato de que, apesar da existência das revistas científicas e da criação das Escolas de Polícia, os soldados e praças continuavam a ser um grupo que lia muito pouco e que aprendia a ser policial não em sala de aula ou em cursos de formação, mas no dia a dia, com os veteranos. Era com eles que policiais mais novos acumulavam uma expertise que os guiava em suas atividades, aprendendo a identificar os suspeitos e a manter a sua autoridade naquele espaço vazio de regulamentação jurídica que eram as ruas de bairros periféricos.

Como desataca Bretas, as formas de "transmissão de um saber (cop knowledge) se referem à narração de histórias e casos, vividos no mundo da prática, dos quais se extraem lições"143. Isso era verdade no início do século XX e, aliás, parece uma variável presente nas reflexões sobre cultura policial ainda hoje $\mathrm{e}^{144}$.

Feito esse apanhado sobre o surgimento das polícias no Brasil e em Pernambuco, bem como de algumas de suas práticas e discursos, vou me dedicar, no próximo capítulo, a explicitar a relação do campo jurídico com a soberania policial, a fim de entender como e em que medida as leis e doutrinas jurídicas no campo criminal contribuíram para a construção de uma polícia soberana.

143 BRETAS, Marcos Luiz. Revista Policial: formas de divulgação das polícias no Rio de Janeiro de 1903. História Social, n. 16, primeiro semestre de 2009, p. 103.

144 BARROS, Marcelo. Polícia e tortura no Brasil: conhecendo a caixa das maçãs podres. Curitiba: Appris, 2015. 


\section{SOBERANIA POLICIAL E O CAMPO JURÍDICO}

Uma polícia soberana não atua completamente à margem de qualquer sistema de legitimação. No capítulo anterior, foi possível verificar o quanto, na passagem para o século XX, a polícia buscava melhorar a sua imagem, reforçando a ideia de que se modernizava, aprimorava alguns métodos de investigação e colocava à disposição do público policiais mais "polidos".

Ao lado de todos esses movimentos, buscou essa organização, também, no campo jurídico, teses que lhe fossem favoráveis, disputando sentido acerca de institutos e de conceitos do direito, além de trabalhar especificamente junto ao legislativo em prol de aprovação de projetos de lei de seu interesse. Como lembrava Aurelino Leal em seu livro "Polícia e Poder de Polícia", a partir de sua experiência como chefe de polícia do Distrito Federal: “A polícia é sempre mal vista e mal julgada. Compreende-se, portanto, quanto me interessava esclarecer o Poder Judiciário e quanto me valeu o apoio legal que ele prestou aos meus atos de autoridade" 145 .

Neste capítulo, vou examinar a relação entre a polícia e o campo jurídico, debruçandome sobre as leis - sobretudo processuais penais - e suas reformas ao longo do século XIX e início do século XX, que contribuíram para o fenômeno da soberania policial. Além disso, buscarei na doutrina processual penal brasileira as interpretações sobre a atividade policial e seus limites, procurando entender como esses autores interpretavam e harmonizavam - se é que o faziam - previsões constitucionais e legais bastante liberais com práticas policiais corriqueiramente não submetidas a controle judicial e, muitas vezes, arbitrárias.

Por fim, concluo com a análise de um evento importante no qual se reuniram polícia e justiça para discutir questões de segurança pública e nacional no Brasil: a Conferência Judiciária-Policial de 1917. A simples existência desse evento demonstra que à polícia era cara uma acolhida jurisprudencial e jurídica de suas atividades para não se confundir com uma organização meramente tirânica e ilegal, como já disse. Por outro lado, a presença massiva de juristas, incluindo autoridades como ministros do Supremo Tribunal Federal no encontro, certifica que alguns membros do campo jurídico no Brasil estariam dispostos a colaborar no combate à desordem pública. Alguns, sem dúvidas, menos apegados aos preceitos liberais da Constituição e mais propensos à aceitação de teses de defesa social, outros mais liberais e desconfiados com o excesso de poder policial. Todos, entrementes,

${ }^{145}$ LEAL, Aurelino. Polícia e poder de polícia. Rio de Janeiro: Imprensa Nacional, 1918. 
entendendo a importância do poder judiciário na construção da legitimidade das forças de segurança pública.

Uma ressalva importante a se fazer neste ponto é a respeito da incontestável existência de dissidência no campo jurídico, que não se constitui como um ambiente hegemônico. Afinal, desde a formação de um sistema de garantias processuais liberais ainda na Constituição de 1824 e de 1891, seria sempre possível, em tese, recorrer ao poder judiciário para sanar eventuais ilegalidades praticadas pelas forças policiais. Porém, os cidadãos frequentemente atingidos por essas arbitrariedades recorriam à justiça? Quando o faziam, obtinham êxito?

Pesquisas históricas sobre o habeas corpus e outras ações de liberdade, por exemplo, em períodos críticos da política brasileira, demonstram que alguns atores do direito utilizaram-se desses instrumentos para fazer cessar alguma ilegalidade e que, no judiciário, muitas vezes acabaram tendo seu pleito atendido.

Keila Grinberg analisou ações de liberdade intentadas em prol de escravos no início do século XIX no Brasil e encontrou um - para ela e também para mim - surpreendente número de alforrias adquiridas através de decisões judiciais proferidas pelo Tribunal de Relações e o Supremo Tribunal de Justiça ${ }^{146}$. Para a autora, a explicação disso estaria na formação e origem dos juristas no Brasil, muitas vezes desvinculados da estrutura agrário-escravista, na influencia do jusnaturalismo nas faculdades de direito, a apregoar um direito natural à liberdade e na inevitabilidade da abolição da escravidão. Neste último caso, juristas passariam a se posicionar em prol do direito de liberdade, procurando espaços de protagonismo nas mudanças históricas ${ }^{147}$.

Já Andrei Koerner analisou o julgamento de habeas corpus entre 1841 e 1920 e concluiu que, com a intensificação das atividades policiais de controle de circulação das pessoas nas cidades no fim do século XIX e início do século XX, houve um aumento considerável de impetração do writ. Para ele, esse aumento "aponta o crescimento, mesmo que em patamares bastante inferiores, da demanda da garantia judicial do direito à liberdade

\footnotetext{
${ }^{146}$ A Constituição de 25 de março de 1824, no art. 163, dispunha: "Na Capital do Império, além da Relação, que deve existir, assim como nas demais Províncias, haverá também um Tribunal com a denominação de Supremo Tribunal de Justiça, composto de Juízes letrados, tirados das Relações por suas antiguidades; e serão condecorados com o título de Conselho. Na primeira organização poderão ser empregados neste Tribunal os Ministros daqueles que se houverem de abolir." A denominação "Supremo Tribunal Federal" foi adotada na Constituição Provisória publicada com o Decreto n. ${ }^{\circ}$ 510, de 22 de junho de 1890, e repetiu-se no Decreto n. ${ }^{\circ}$ 848, de 11 de outubro do mesmo ano, que organizou a Justiça Federal.

147 GRINBERG, Keila. Liberata: a lei da ambiguidade - as ações de liberdade da corte de apelação do Rio de Janeiro do século XIX. [online]. Rio de Janeiro: Centro Edelstein de Pesquisa Social, 2010. Available from SciELO Books, p. 50-53.
} 
individual por parte dos atingidos pela ação policial, ou seja, da tentativa de acesso à cidadania por essa via" ${ }^{148}$. A resposta judicial a essas demandas era, por vezes, favorável ao preso, denotando a existência de juristas mais comprometidos com o direito de liberdade ou a simples legalidade.

$\mathrm{O}$ autor, entretanto, faz uma ressalva a esses achados de pesquisa. O volume de prisões diárias realizadas pela polícia sempre foi muito maior que o de habeas corpus que chegam à justiça, sugerindo, portanto, que apenas uma pequena parcela desses atos passava por algum controle. Em outras palavras, a estrutura do sistema de justiça criminal à época alijava muitos dos cidadãos que sofriam constrangimentos ilegais de um caminho para a tutela de seus direitos e Koerner também apresenta uma explicação para isso.

A doutrina processual penal da época entendia que o pedido de habeas corpus deveria ser instruído com a cópia da decisão que decretava a prisão. Entretanto, como já comentei e também o autor confirma, muitas prisões na época eram realizadas por policiais sem qualquer ordem escrita, tornando impossível a apresentação dessa decisão na petição. Assim:

Na prática, muitos presos não conseguiriam ajuizar a ação constitucional porque certamente não cumpririam essa formalidade. Tudo isso se fundamentava em um princípio de presunção de legalidade de atos de agentes do poder público, devendo o cidadão demonstrar o contrário ${ }^{149}$.

E conclui:

[...] apesar de os estudos sobre a atividade policial e sobre as prisões do Império mostrarem a importância das detenções cotidianas por vadiagem e outros pequenos delitos para o controle social, não encontramos nenhuma referência à utilização de habeas corpus para acusados de vadiagem ${ }^{150}$.

Não significava simplesmente que pobres e negros não acessassem em absoluto a justiça penal; mas, a maior parte deles, que ocupavam as ruas das cidades de forma ameaçadora para a elite brasileira, o habeas corpus não era uma possibilidade. Esse quadro, de fato, alterou-se um pouco com a República, mas não substancialmente ou ao ponto de se poder afirmar que o habeas corpus teria cumprido um papel sistemático de combate aos excessos policiais.

\footnotetext{
${ }^{148}$ KOERNER, Andrei. Habeas corpus, prática judicial e controle social no Brasil: 1841-1920. São Paulo: IBCCRIM, 1999, p. 137.

149 KOERNER, Andrei. Habeas corpus, prática judicial e controle social no Brasil: 1841-1920. São Paulo: IBCCRIM, 1999, p. 137, p. 67.

${ }^{150}$ KOERNER, Andrei. Habeas corpus, prática judicial e controle social no Brasil: 1841-1920. São Paulo: IBCCRIM, 1999, p. 89.
} 
Ainda, pesquisas realizadas sobre o período ditatorial brasileiro demonstram que o habeas corpus constitua uma importante arma para a soltura de presos políticos, a tal ponto de ter o Ato Institucional n. 5 proibido o remédio. Walter Cruz S. Junior verificou que, entre 1964 e 1968, 135 habeas corpus foram impetrados perante o STF, tendo 99 deles a ordem concedida. Os resultados, desfavoráveis ao Regime Militar, teriam impelido o Presidente Costa e Silva a nomear novos ministros a aumentar o número deles de onze para dezesseis. Ainda assim, ordens de habeas corpus continuavam a ser concedidas, até a proibição completa do remédio em $1968^{151}$.

Enfim, embora aqui eu vá buscar analisar os elementos do campo jurídico que acabaram por favorecer uma atuação livre e sem controle da polícia, sei que sempre existiram espaços - ainda que discretos - de disputa que foram úteis para contornar algumas ilegalidades e poupar vidas ${ }^{152}$. Porém, essas ações e instrumentos jurídicos pontuais não conseguiam vencer uma ordem baseada no controle policial exercido em moldes soberanos.

\subsection{SILÊNCIOS, LIBERALISMO À BRASILEIRA E SOBERANIA POLICIAL}

No capítulo anterior, falei sobre o surgimento das forças policiais no Brasil e de algumas de suas características. Ao lado desses aspectos de ordem cultural e organizacional, é fundamental compreender o papel das legislações e da doutrina jurídica no modelamento das práticas policiais, o que caberia preferencialmente ao campo processual penal, haja vista normatizar acerca das agências do sistema de justiça criminal e suas atribuições e competências.

O direito penal possui um papel fundamental no modelamento das práticas punitivas, porque estabelece as condutas consideradas criminosas, os critérios de imputação de um fato criminoso e a medida da responsabilidade do sujeito. Porém, é no processo penal e seus institutos que se encontram relevantes chaves interpretativas acerca da relação entre agências do sistema penal e seus cidadãos.

O processo penal não apenas estabelece procedimentos de apuração, processamento e julgamento dos crimes, mas também regras relativas às prisões antes da condenação, à atribuição das autoridades, ao controle destas, à intensidade de interferência das autoridades

${ }^{151}$ SWENSSON JR. Walter Cruz. O Supremo Tribunal Federal (1964-1969). KOERNER, Andrei (org.). História da justiça penal no Brasil: pesquisas e análises. São Paulo: IBCCRIM, p. 227-240, 2006, 237.

${ }^{152}$ Sobre esse tipo de trabalho Gislene Neder adverte: "pode ser pitoresco levantar um fundo arquivístico onde se revela uma certa quota de processos jurídicos abertos por escravos, procurando assegurar seus direitos. Deve-se tomar o cuidado de estudar o contexto mais geral da condição escrava no Brasil; número total dos processos, sexo do/a demandante, lugar de trabalho, para, então, poder analisar as possibilidades históricas de produção de efeitos de resistência à ordem escravista através do recurso à lei”. NEDER, Gislene. Iluminismo Jurídico-Penal Luso-Brasileiro. Obediência e submissão. 2 ed. Rio de Janeiro: Revan, 2007, p. 190. 
do Estado na intimidade dos indivíduos, à produção de provas etc. São as regras do processo que apresentam o caráter mais ou menos democrático e liberal de um Estado.

Desse modo, compreender a soberania policial no Brasil é perpassar a análise do processo e, neste ponto, a primeira reflexão necessária a se fazer é sobre silenciamento. Quando comecei a manusear os livros de processo penal do século XIX e início do XX, verifiquei uma quase ausência de reflexões sobre as polícias. Não quer dizer que nada existia e que os livros fossem idênticos. Ao contrário, há alguns muito mais robustos, que dedicam alguns capítulos à polícia, mormente à judiciária, como os manuais de João Mendes de Almeida Junior e de José Antônio Pimenta Bueno.

Porém, no geral, o que se lê nessas publicações é, quase sempre, uma anunciação de atribuições e papeis de forma acrítica, que, aliás, vão se modificando ao prazer das mudanças legais. “À polícia judicial cabe...”, “Os chefes de polícia podem...”, “O inquérito policial é...” e, raramente, passava-se dessas descrições. Às vezes, essa ausência é até justificada. É curioso quando João Mendes de Almeida - mesmo, de fato, dedicando muitas páginas à polícia afirma categoricamente que os processualistas devem cuidar de disciplinar e teorizar acerca do inquérito policial e da polícia judiciária, mas que não devem se dedicar às atividades das polícias administrativas. Nas palavras do autor:

Nós temos que nos ocupar da polícia judiciária. Dahi decorre que, no interesse da justiça, dous princípios devem dominar a organização da polícia judiciária: $1^{\circ}$ ella deve ser investida dos meios de acção indispensáveis; $2^{\circ}$ ella deve ser munida de fórmas tutelares que se aproximem tanto quanto possível das formas da acção judiciaria ${ }^{153}$.

Também se posicionava desta forma João Evangelista Peixoto Fortuna, para quem "da polícia administrativa nós não temos que nos ocupar nesse estudo porque o seu objeto é matéria do direito administrativo, não cabendo, pois, agora à nossa alçada"154.

Nessa toada, nada mais é possível encontrar acerca da intervenção policial na vida cotidiana das cidades, embora elas movimentassem, e muito, o campo criminal. No próximo capítulo, demonstrarei que, apenas no Recife, cerca de dez pessoas eram diariamente abordadas por praças ou guardas civis e encaminhadas a delegacias de polícia, onde eram presas por delegados, subdelegados e chefes de polícia, sem que essas detenções estivessem sujeitas a qualquer controle judicial. Ao mesmo tempo, a polícia aplicava técnicas ilícitas de

${ }^{153}$ ALMEIDA JR, João Mendes de. O processo criminal brazileiro. Vol. I. 3 ed. Rio de Janeiro: Typ. Baptista de Souza, 1920, p. 275.

${ }^{154}$ FORTUNA, João Evangelista Peixoto. Manual de direito processual Criminal. Rio de Janeiro: Typographia Bedeschi, 1915, p. 9. 
investigação e apuração de atos criminosos sem que também, aparentemente, isso incomodasse substancialmente os doutrinadores do campo processual à época.

Dessa forma, sem comentar sobre as prisões correcionais ou para averiguação das polícias, sem falar da prática de infiltrar agentes policiais em organizações operárias, sem mencionar a possibilidade que tinham policiais de perseguir a imprensa operária ou de regulamentar a atividade da prostituição - algumas das técnicas de uma polícia soberana - as versões oficiais da doutrina do processo penal brasileiro davam a nítida impressão de que a intervenção penal no Brasil ocorria nos moldes preconizados pelas doutrinas mais modernas e liberais do período.

Na introdução de seu livro sobre o Código de Processo Criminal de 1832, Braz Florentino H. de Souza já antepunha os valores com os quais o processo penal lidava e que, de certa forma, parece ser objeto de tensão ainda hoje: “manter um perfeito equilíbrio entre os meios de atacar o crime e as garantias de que se deve cercar a innocencia"155.

No mesmo sentido, Francisco Duarte Nazareth, no prólogo de seu livro intitulado Elementos do processo criminal, no qual compara a legislação processual penal portuguesa e brasileira, apresenta o processo penal a partir de seu principal desafio: compatibilizar garantias individuais com a necessidade de segurança. Para Nazareth:

Se estes princípios se não mantiverem em equilíbrio e preponderar um mais que outro; ou se as regras, e formas, que a lei do processo estabelecer, forem incompletas, imprevidentes, e não adaptadas a conciliar as garantias da ordem social e da liberdade civil, então o erro da lei (... ) ferirá os cidadãos em sua liberdade, na sua fortuna; e na sua vida ${ }^{156}$.

Já João Mendes de Almeida, ao definir o processo penal, afirmava se tratar de um conjunto de leis que funcionavam como um complemento necessário das leis constitucionais. "As formalidades do processo são as actualidades das garantias constitucionais"157 e, por essa razão, eram a expressão técnica das declarações dos direitos do homem e do cidadão que, a partir do século XVIII, estamparam-se em diversas Cartas Constitucionais do mundo ocidental, incluindo as brasileiras.

\footnotetext{
${ }^{155}$ SOUZA, Braz Florentino Henriques de. Código do Processo Criminal de Primeira Instância do Império do Brasil. Recife: Tipografia Universal, 1860, p. 5.

${ }^{156}$ NAZARETH, Francisco J. Duarte. Elementos do processo criminal. Coimbra: Imprensa da Universidade, 1886.

${ }^{157}$ ALMEIDA JR, João Mendes de. O processo criminal brazileiro. Vol. I. 3 ed. Rio de Janeiro: Typ. Baptista de Souza, 1920, p. 9.
} 
Parece-me, inclusive, que no final do século XIX e início do século XX, os juristas estavam mais preocupados em seus discursos com a preservação das liberdades individuais do que aqueles que, juntos, compunham o debate nacional na década de 1930, que gerou os Códigos Penal e de Processo Penal de 1940 e 1941, respectivamente ${ }^{158}$. Por certo, o avanço de regimes e teorias autoritárias na Europa reverberou em terras brasileiras e, no campo processual penal, no fortalecimento das ideias de defesa social em detrimento do liberalismo individual, de que é bastante elucidativa a exposição de motivos do Código de Processo Penal construída por Francisco Campos.

Longe de um ideal de defesa social acima de qualquer liberdade individual, nos livros, temas como habeas corpus, limites às prisões ilegais, presunção de inocência, inviolabilidade domiciliar, devido processo legal, dentre outros corolários de um processo penal acusatório, estavam presentes e marcavam as reflexões dos autores. Natural que, em certa medida, dada a natureza prescritiva do direito, era esse "dever ser" a temática essencial desses livros.

Todavia, ao mesmo tempo, ao deixar de lado o dia a dia da criminalização das camadas populares no Brasil, como dito acima, esses processualistas permitiam que a cisão entre uma teoria liberal e moderna e uma prática cotidiana violenta se perpetuasse ${ }^{159}$, o que, aliás, poupou-os das críticas mais ferrenhas da criminologia crítica, quase sempre destinadas aos penalistas do período ${ }^{160}$.

\footnotetext{
158 Camila Prando recupera os debates no campo criminal realizados na década anterior à aprovação dos referidos códigos, demonstrando que "o limite para o poder punitivo não era o indivíduo em sua dimensão de direitos invioláveis, mas sim a eficiência das intervenções terapêuticas e científicas da pena", o que fugia muito à dimensão inicial do liberalismo penal clássico. Ver: PRANDO, Camila C. de M. O saber dos juristas e o controle penal: o debate doutrinário a Revista de Direito Penal (1933-1940) e a construção da legitimidade pela defesa social. Rio de Janeiro: Revan, 2013, p. 201.

${ }^{159}$ Gisela Aguiar Wanderley nos provoca sobre esse silenciamento nos cursos jurídicos e na doutrina até hoje, sugerindo que, no essencial, essa postura não se alterou. No geral, ele pontua que ignoramos assuntos como a busca pessoal e abordagem policial, embora, cotidianamente, milhares de pessoas, sobretudo pobres e negras, sejam abordadas por agentes policiais sem qualquer critério legal, baseando-se esses agentes em lógicas informais da organização sobre "atitude suspeita". Ao final, com elas não são apreendidas drogas, armas ou outros materiais ilegais, isto é, a abordagem parece não ter a eficácia apregoada. Para Gisela, quando processualistas deliberadamente optam por não falar sobre isso, estão deixando à polícia o terreno completamente livre para atuarem com arbitrariedade. Conferir: WANDERLEY, Gisela Aguiar. Liberdade e suspeição no Estado de Direito: o poder policial de abordar e revistar e o controle judicial de validade da busca pessoal. Dissertação de Mestrado. Programa de Pós-Graduação em Direito. UnB. 2017.

${ }^{160}$ Noções como periculosidade, tratamentos terapêuticos, prisões de curta duração, culpabilidade, medidas de segurança, que foram bastante influenciadas pelas ideias correcionalistas da criminologia positivista, mereceram a atenção do penalismo crítico e da criminologia crítica, porque pareciam acolher em maior medida os preceitos daquelas Escolas. Porém, é fundamental compreender como aqueles ideais reverberaram no campo processual penal, notadamente nos saberes produzidos por policiais e para a intervenção policial, como o caso da identificação criminal, do estatuto da presunção de inocência e das prisões provisórias. Afinal, nada mais evidente do que a vitória do ideal de defesa social do que as práticas policiais ora estudadas e as compreensões que passamos a construir acerca de conceitos como ordem pública, prisão cautelar, identificação criminal, elemento suspeito, prisão para averiguação etc.
} 
Afinal, como o liberalismo que inspirou códigos e obras de processo penal conviveu com atribuições judiciais dadas à polícia? Como a defesa irrefreável da inviolabilidade domiciliar coexistiu com a possibilidade de mandados de busca e de apreensão serem expedidos por chefes de polícia? Como a liberdade se anuncia como um bem jurídico de valor inestimável frente a uma ordem jurídica que admitia prisões realizadas a critério da polícia, sem qualquer controle judicial? Isso para mencionar apenas as práticas oficiais...

A contradição vivenciada no campo jurídico é o reflexo daquela construída no campo político. Muitos estudos se debruçaram sobre essa incoerência entre o pensamento político brasileiro e as práticas das instituições de nosso país. Roberto Schwarz, por exemplo, ressalta a incompatibilidade da recepção dos ideais liberais burgueses no Brasil escravocrata do século XIX.

Para ele, "as ideias liberais não se podiam praticar, sendo ao mesmo tempo indescartáveis"161 em um país escravocrata e agrário, mas que pretendia se afirmar como moderno. As relações sociais em nosso país estavam rigidamente e contratualmente estabelecidas entre latifundiários e escravos e marcadas pelo favor entre os primeiros e a massa de homens livres. Médicos, advogados, professores, pequenos produtores, todos estavam, em certa medida, dependendo de privilégios para ocupar cargos, funções, postos de trabalho e proteção econômica e essa ordem do favor era também o oposto do liberalismo apregoado nas ideias e nos documentos jurídicos. Nem o escravismo e nem o favor poderiam corresponder às concepções europeias de isonomia, despersonalização das relações, de burocratização racional legal do Estado... Porém, as relações sociais no Brasil se forjaram amparadas pela violência brutal do escravismo de um lado, e, de outro, pelo favoritismo, ambos sob um manto de legalidade e liberalismo estampados nas constituições.

A Constituição de 1824, por exemplo, não mencionava a escravidão e apenas se referia a um amplo direito à propriedade privada ${ }^{162}$, dispositivo que autorizava o Código Civil a tratar os escravos como coisas. Ao mesmo tempo, apregoava uma administração pública baseada na impessoalidade. Já os Códigos Criminal de 1830 e de Processo Criminal de 1832 possuíam dispositivos liberais, embora não escondessem que se assentavam em uma ordem escravocrata, conforme será exposto adiante.

É possível refletir um pouco além da realidade brasileira e verificar que o constitucionalismo liberal não foi estranho a ordens excludentes baseadas em uma distinção

\footnotetext{
${ }^{161}$ SCHWARZ, Roberto. As ideias fora do lugar: ensaios selecionados. São Paulo: Penguin Classics Companhia das Letras, 2014, p. 59.

${ }^{162}$ ZAFFARONI, E. R.; BATISTA, N; ALAGIA, A.; SLOKAR, A. Direito penal brasileiro - I. Rio de Janeiro: Revan, 2006, p. 424.
} 
biológica ou social entre as pessoas. O pensamento liberal clássico tem como pressuposto filosófico o jusnaturalismo e a crença na dignidade da pessoa humana. Porém, é justamente no período em que ele se desenvolve em território europeu - a partir do século XVI - que se iniciam as incursões colonizadoras, o choque com o Outro e a consequente distinção entre grupos humanos brancos e não brancos que, por certo, nortearam a oferta de direitos nas sociedades europeias e fora delas, conforme lembrei no primeiro capítulo.

Giorgio Agamben entende que sequer esse descompasso é constitutivo do liberalismo político. Para ele, as concepções iluministas de igualdade e humanidade, assim como as declarações de direitos burguesas que anunciariam esses ideais no século XVIII, não representavam, em verdade, um projeto político de equidade e universalização de direitos. Para ter direitos era preciso pertencer ao projeto nacional; aos de fora, os estrangeiros, reservava-se o não-direito.

Para o autor, a "Declaração dos Direitos do Homem e do Cidadão", da França revolucionária, por exemplo, estava não por acaso direcionadas aos cidadãos, já que “o estatuto do refugiado foi sempre considerado, mesmo no melhor dos casos, como uma condição provisória, que deve levar ou à naturalização ou à repatriação"163. Os refugiados, não nacionais, não nascidos no território dos Estados-Nação ostentaram sempre o status de marginais. Nesse momento, os critérios de atribuição de nacionalidade do jus soli ou jus sanguinis definem quem é francês e, como tal, detentor de direitos.

A referida Declaração dirá que "todos os homens nascem com direitos inalienáveis e imprescritíveis" e que esses homens compõem a nação soberana francesa. Sendo assim, ele conclui, "o nascimento - isto é, a vida nua natural como tal - torna-se aqui pela primeira vez (com uma transformação cujas consequências biopolíticas somente hoje podemos começar a mensurar) o portador imediato da soberania"164.

No Brasil, o nascimento também definiria a quem se reserva um tratamento humano e a quem ele seria negado. Nascer de mãe escrava era ser escravo e, como tal, estar desprotegido do anteparo liberal que a Constituição de 1824 previu. Porém, além disso, a identificação do ser negro com a bestialidade faria de todas essas pessoas - ainda que não escravas - mais suscetíveis a tratamentos cruéis, a penas corporais mais rígidas e à própria pena de morte ${ }^{165}$. A desumanidade promovida pelo racismo ainda tornou garantias

\footnotetext{
163 AGAMBEN, Giorgio. Meios sem fim: notas sobre política. Belo Horizonte: Autêntica Editora, 2015, p. 28.

${ }^{164}$ AGAMBEN, Giorgio. Homo sacer: O poder soberano e a vida nua. Belo Horizonte: Editora UFMG, 2014, p. 125.

${ }^{165}$ Estudos contemporâneos realizados nos Estados Unidos demonstram que a associação entre negros e macacos influencia no tratamento dispensado a réus e a rés negros pelo sistema punitivo. 'Especificamente, há uma
} 
processuais penais letra morta para todo esse grupo de pessoas, passíveis de sofrerem punições sem processo (abuso das prisões processuais), violação em seus domicílios, torturas e a outras técnicas de um direito processual autoritário ou de exceção.

Foi assim que a nossa sociedade caminhou ao longo do século XIX, convivendo com essas contradições que pouco chegaram a inquietar juristas em geral e processualistas em especial, haja vista, como disse, o silêncio acerca dos deveres e direitos que as polícias teriam ao desempenhar suas funções ${ }^{166}$.

Repito: os processualistas estavam, em geral, comprometidos com a defesa de direitos de liberdade. As disputas no legislativo e do campo acadêmico sobre o habeas corpus, sobre as atribuições judiciais dadas à polícia, dentre outras, é testemunha dessa preocupação. Porém, mesmo nesses debates, muitas vezes as vicissitudes relacionadas ao excesso do Estado são, ainda, ligadas à elite branca. Muito curiosa é a observação que Koerner faz a respeito do habeas corpus na primeira década do século XX:

O habeas corpus foi criado no Código de Processo como uma garantia judicial, como um instituto de caráter político. Sua principal utilização no período regencial aparentemente relacionava-se às lutas políticas. Nos debates parlamentares está presente o problema político central do período: a oposição entre liberais e futuros conservadores a respeito da centralização versus descentralização do governo imperial ${ }^{167}$.

Aos poucos esse remédio vai se alastrando e beneficiando outros sujeitos, embora não chegue propriamente a se universalizar como método de contenção da violência estatal, conforme pontuei acima.

Por fim, o que é fundamental para seguir adiante na reflexão é compreender não apenas que entre o texto jurídico e a realidade há um abismo, como também a própria manutenção do abismo é uma das funções do texto. Desse modo, entre o silêncio e a não operacionalidade, construímos uma ordem legal que deu à polícia uma "soberania pura"168

tendência em se intensificar a violência policial e decisões para executar negros' naquele país, segundo Akwasi Owusu-Bempah. OWUSU-BEMPAH, Akwasi. Race and policing in historical context : deshumanization and the policing of Black people in the 21th century. Theoretical criminology, 2016, p. 7.

${ }^{166}$ É preciso mencionar que a violência policial era um tema conhecido de todos e, inclusive, citado, ainda que en passant, em muitas das obras jurídicas do período. Li muitas vezes a referência à truculência policial, sobretudo perpetrada pela polícia militar, cuja imagem, como visto, era bastante negativa. Mas as considerações não passavam da simples constatação.

167 KOERNER, Andrei. Habeas corpus, prática judicial e controle social no Brasil: 1841-1920. São Paulo: IBCCRIM, 1999, p. 60.

168 BATISTA, Vera M. O medo na cidade do Rio de Janeiro: dois tempos de uma história. Rio de Janeiro: Editora Revan, 2003, p. 143. 
para atuar nas ruas, realidade que se estendeu, a despeito de modificações legais e políticas, para o início da República. Como isso foi possível?

\subsection{A PROGRAMAÇÃO CRIMINALIZANTE DO SÉCULO XIX E SEUS REFLEXOS NO INÍCIO DA REPÚBLICA}

Antes de adentrar a temática da legislação processual penal, é preciso retomar um pouco um assunto bastante abordado pelo pensamento criminológico brasileiro: a programação criminalizante do século XIX e a sua relação com o povo negro.

Até o início do século XIX, o Brasil era majoritariamente rural, e o direito penal, exercido pelos proprietários de escravos. Desse período ressoam angustiantes relatos de punições que não eram prescritas em qualquer legislação, apesar de aplicadas. Queimar orelhas, narizes e boca, jogar corpos negros em caldeiras de melaço de cana, marcar a pele do corpo ou do rosto com brasa, além dos mais conhecidos açoites constituíam o conjunto de penas aplicáveis sem processo penal, no latifúndio brasileiro ${ }^{169}$.

Aos poucos, as cidades passaram a ser um espaço de circulação de um grande número de pessoas, dentre elas, negros escravos e libertos. Como destaca Vera M. Batista, nesse período, uma parcela considerável da população brasileira era negra. No Rio de Janeiro de $1834,44,4 \%$ do total da população era escrava, o que fez se cunhar a expressão "cidade negra" e alguns bairros chegarem a ser conhecidos como "Pequena África"170. Essa nova dinâmica demográfica suscitará mudança nos aparatos de controle. Para Evandro Piza Duarte:

se os quilombos colocaram na agenda política a necessidade de forças
regulares para além daquelas municipais que eram inicialmente a reunião de
forças dos senhores locais, a cidade colocará em pauta a constituição de um
espaço público, onde os conflitos se davam cotidianamente entre os
diferentes grupos sociais e, portanto, de um controle público desse espaço ${ }^{171}$.

Além do aumento da circulação de negros pelas cidades, o Brasil do início do século XIX registra uma série de revoltas, como a Revolta dos Malês na Bahia, a balaiada no Maranhão, a Cabanagem no Pará, que farão suscitar o pavor de uma desestabilização profunda na sociedade. As elites brancas do século XIX nutriram, de fato, um enorme medo de insurreições negras que pudessem pôr em xeque o sistema social e econômico que as

\footnotetext{
169 ZAFFARONI, E. R.; BATISTA, N; ALAGIA, A.; SLOKAR, A. Direito penal brasileiro - I. Rio de Janeiro: Revan, 2006, p. 414-415.

170 BATISTA, Vera M. O medo na cidade do Rio de Janeiro: dois tempos de uma história. Rio de Janeiro: Editora Revan, 2003, p. 129.

${ }^{171}$ DUARTE, Evandro Charles Piza. Criminologia e racismo. 1 ed. Curitiba: Juruá, 2011, p. 165.
} 
mantinha, acabar com a escravidão e, ainda, repetir o ocorrido no Haiti em 1791. Como destacou Célia M. M. de Azevedo:

\begin{abstract}
As três primeiras décadas do século XIX só viriam a confirmar estas sombrias expectativas com o desenrolar das insurreições baianas, detalhadamente organizadas pelos haussás e nagôs. E se elas não conseguiriam alcançar seus objetivos, nem por isso eram menos atemorizantes. A persistência um dia poderia ter sucesso e em muitos ouvidos educados ressoava, ameaçadora, a cantiga entoada em 1923 nas ruas de Pernambuco: 'Marinheiros e caiados/ Todos devem se acabar/ Porque só pardos e pretos/ O país hão de habitar' ${ }^{172}$.
\end{abstract}

No período, há notícias de pessoas detidas por haitianismo e negros foram vistos, segundo autoridades policiais, "ostentando no peito o retrato de Dessalines, o ex-escravo e 'Imperador dos Negros da Ilha de São Domingos""173. Esses acontecimentos políticos alimentaram a imagem que homens brancos nutriam dos negros como seres bestiais.

Clovis Moura se refere a uma Síndrome do Medo e cita documentos da classe senhorial da Bahia nos quais se verifica enorme pavor de tais rebeliões e, ao mesmo tempo, exigências dirigidas ao Governo para que providências fossem tomadas. Em uma dessas passagens, estonteante pelo uso da palavra 'humanismo' para lidar com suas demandas, esses senhores imploram ajuda em uma situação que para eles se tornava insuportável:

a falta de polícia, que geralmente se observa nesta cidade, pelas muitas larguezas que se lhes tem dado, de sorte que são contínuos os insultos, atacando vergonhosamente as mulheres brancas. Isto ainda mais onde há castigo; pois que chegou o tempo de até os senhores serem repreendidos pelo governo se o fazem, mesmo com justiça, atendendo-se mais as queixas dos negros, que as razões dos senhores, e chama-se a isto de humanidade, e idade e ouro do Brasil; mas assim o é para os negros que têm o privilégio de humanidade, e nós de desumanidade ${ }^{174}$.

Célia Marinho, na obra já citada, fez um apanhado de autores que, ao longo do século XIX, ressaltaram a natureza bárbara, indisciplinar e perigosa dos negros africanos, colocandose, inclusive, contrários ao regime escravista, pois seria uma maneira de poupar o território nacional e mesmo a nação brasileira dessas más influências. João Severiano Maciel da Costa,

\footnotetext{
172 AZEVEDO, Célia Maria Marinho de. Onda negra, medo branco: o negro no imaginário das elites do século XIX. 3 ed. São Paulo: Annablume, 2004, p. 29.

173 CHALHOUB, Sidney. Medo branco de almas negras: escravos, libertos e republicanos na cidade do Rio de Janeiro. Revista Brasileira de História. V. 8, n. 16, p. 83-105, mar/ago, 1988, p. 88.

${ }^{174}$ Apud MOURA, Clovis. Sociologia do negro no Brasil. São Paulo: Editora Ática, 1988, p. 234.
} 
que, conforme pontuei no primeiro capítulo, foi deputado constituinte em 1823, por exemplo, em 1821, escrevia que o tráfico negreiro tornava a população brasileira por demais heterogênea e, pior, cheia de elementos inimigos da classe livre ${ }^{175}$. José Eloy Pessoa da Silva também propôs a extinção gradual do tráfico africano, entendendo que "essa população escrava, longe de dever ser considerada como um bem, é certamente um grande mal"176.

Todo esse pavor será acompanhado de demandas punitivas, da criação de aparatos de controle e de uma programação criminalizante que visava precipuamente à população negra do país ${ }^{177}$. O personagem do Major Vidigal, sobre o qual já falei neste trabalho, representa uma polícia que, evidentemente, a essa altura, já atuava preferencialmente sobre corpos negros, utilizando-se de métodos violentos para isso. Capoeiragem, fuga e furtos, por exemplo, eram as principais condutas pelas quais a polícia prendia na cidade do Rio de Janeiro, entre os anos de 1810 e 1820.

Nesse período, a soberania policial era plena. Em 1825, por exemplo, o decreto de novembro criou o cargo de comissário na polícia do Rio de Janeiro e concedeu-lhe a atribuição de impedir ajuntamentos, reprimir a vadiagem e cadastrar capitães-do-mato. Os comissários poderiam cumprir essas tarefas por meio de simples regulamentos de polícia.

A Lei de $1^{\circ}$ de Outubro de 1828 se soma a essa tendência: permite às Câmaras Municipais criarem infrações de natureza administrativa, que podiam gerar penalidade de prisão ou multa. Eram as chamadas Posturas Municipais, conjunto de normas que, ao longo de todo o século XIX e em várias cidades brasileiras, perseguiu determinadas condutas típicas dos grupos negros, proibindo as mais diversas atividades como sambas, vozerias, beber em público, reuniões, receber pessoas negras em tavernas, dentre outras.

Clarissa Nunes Maia estudou as posturas pernambucanas entre 1856 e 1869 e entre 1870 e 1883, percebendo que houve, de um período para outro, um aumento no número de previsões sobre comportamentos sediciosos de escravos, demonstrando que, à medida que as cidades foram crescendo e a população negra de livres e cativos se confundindo, e também ao se chegar mais perto da abolição, a preocupação com o controle da população escrava se tornou ainda mais intensa.

De fato, a partir de 1870, o clima abolicionista, a proibição do tráfico de escravos e a expansão do mercado livre criaram um clima de "fuga para dentro". Ao invés de negros

175 AZEVEDO, Célia Maria Marinho de. Onda negra, medo branco: o negro no imaginário das elites do século XIX. 3 ed. São Paulo: Annablume, 2004, p. 32.

176 AZEVEDO, Célia Maria Marinho de. Onda negra, medo branco: o negro no imaginário das elites do século XIX. 3 ed. São Paulo: Annablume, 2004, p. 35.

177 BATISTA, Vera M. O medo na cidade do Rio de Janeiro: dois tempos de uma história. Rio de Janeiro: Editora Revan, 2003, p. 135. 
escravizados fugirem para quilombos ou mesmo tentarem outras formas de resistência como o suicídio ou o assassinato de senhores de engenho, criou-se a possibilidade de eles viverem junto a negros livres das cidades. Chalhoub comenta que as cidades se tornaram primorosos esconderijos, sendo difícil distinguir o negro escravo e o livre ${ }^{178}$. Para Fernanda Lima

o ambiente urbano de algum modo aproximava os diferentes e forçava maior grau de convivência. Não havia mais o efeito assegurador da senzala, na qual os negros eram lançados e de certa forma afastados. Na cidade, o branco assistia à mobilidade da gente de cor e tomava consciência de sua dimensão populacional $^{179}$.

Esse era o cenário do Recife. Em 1872, 55\% da população do Recife era de negros, ocupando essas pessoas funções de artista, oficiais mecânicos e militares. Nesse contexto, as posturas municipais se tornaram uma importante arma de controle. Como lembra Maia, "os assuntos mais tratados eram as proibições de vender bebidas aos escravos, ao seu ajuntamento em casas comerciais e em casas de batuques, e à sua participação em jogos" ${ }^{180}$. Relevante destacar que tanto a repressão à bebida como a reuniões e a ajuntamentos objetivava tornar mais produtivo o trabalho dos escravos, mas também impedir o contato destes com os homens livres, que, por vezes, auxiliavam-nos em fugas, compravam produtos por eles furtados e desempenhavam outras formas de solidariedade.

$\mathrm{Na}$ Bahia, as posturas municipais possuíam o mesmo conteúdo observado nas cidades pernambucanas. Nilo Batista verifica que os lundus, batuques, algazarras, deambulação de escravo após 21h, venda pólvora etc eram previstas nas Posturas Municipais de cidades como Salvador, Juazeiro e Maracás ${ }^{181}$.

As posturas duraram até o final do século XIX na maioria das cidades, e, no Recife, até 1891, dividindo espaço com a legislação penal na tarefa de controle da circulação de corpos pelo espaço urbano.

No que toca à legislação penal, o Código de 1830 é intrigante. Ele é comumente tratado como um documento liberal pelos seus contemporâneos e críticos posteriores, porque superava o famoso livro $\mathrm{V}$ das Ordenações Filipinas. Também anunciava, em seu artigo $1^{\circ}$, o

\footnotetext{
${ }^{178}$ CHALHOUB, Sidney. Medo branco de almas negras: escravos, libertos e republicanos na cidade do Rio de Janeiro. Revista Brasileira de História. V. 8, n. 16, p. 83-105, mar/ago, 1988, p. 88.

179 SILVA, Fernanda Lima da. Policiados e policiais. Dois tempos de uma história de criminalização. Monografia de final de curso. Faculdade de Direito do Recife-UFPE, 2016, p. 49.

${ }^{180}$ MAIA, Clarissa Nunes. Sambas, batuques, vozerias e farsas públicas: o controle social sobre os escravos em Pernambuco no século XIX (1850-1888). São Paulo: Annablume, 2007, p. 70.

${ }^{181}$ BATISTA, Nilo. Apontamentos para uma história da legislação penal brasileira. Rio de Janeiro: Revan, 2016, p. 36.
} 
princípio da legalidade, uma das principais conquistas do penalismo moderno e um instrumento fundamental para inibir arbitrariedades do Estado.

Porém, esse mesmo código hierarquizou expressamente o tratamento dispensado a escravos e homens livres, estando os primeiros sujeitos às penas mais cruéis cominadas na legislação, como a de morte, galés e açoites. Ao mesmo tempo, possuía disposições que criminalizavam as condutas de vadios e mendigos no capítulo IV $^{182}$ de forma totalmente vaga. Dentro da lógica da contradição já explicitada, o Código definia como delituosa a conduta do vadio, com a seguinte redação "Não tomar qualquer pessoa uma occupação honesta, e útil”. O que é honesto? O que é útil? A abertura semântica de um tipo penal dessa natureza, de que não é único exemplo o crime em exame, permitiu o arbítrio judicial e policial na definição de condutas como criminosas e o "princípio da reserva legal virava pó"183. Somando-se essas disposições abertas às posturas municipais, o caminho para a criminalização de pobres e negros que perambulavam pelas ruas estava livre e desimpedido, não recebendo qualquer mediação de garantias como a legalidade.

O projeto para o Código de 1830 é atribuído a Bernardo Pereira de Vasconcelos, mas, em verdade, tratou-se de uma obra quase coletiva e fruto do contato de juristas brasileiros com o pensamento iluminista em Universidades na Europa. As ideias de liberdade, de direitos do homem, de críticas à tirania estariam presentes nas falas desses juristas, porém, como já frisado acima, esses intelectuais estavam muitas vezes comprometidos com a estrutura agrário-escravista brasileira, razão pela qual “jamais estiveram dispostos a abrir mão, em nome das 'luzes', de sua posição aristocrática" ${ }^{184}$. Finalmente, o Código de 1830 era mais um produto do liberalismo escravocrata brasileiro.

No período pré-abolição, novamente vêm à tona os discursos atemorizados com a perspectiva de se liberar um enorme contingente de pessoais vistas como bestiais. Em 1880, o

\footnotetext{
182 Art. 295. Não tomar qualquer pessoa uma occupação honesta, e util, de que passa subsistir, depois de advertido pelo Juiz de Paz, não tendo renda sufficiente.

Pena - de prisão com trabalho por oito a vinte e quatro dias.

Art. 296. Andar mendigando:

$1^{\circ}$ Nos lugares, em que existem estabelecimentos publicos para os mendigos, ou havendo pessoa, que se offereça a sustental-os.

$2^{\circ}$ Quando os que mendigarem estiverem em termos de trabalhar, ainda que nos lugares não hajam os ditos estabelecimentos.

$3^{\circ}$ Quando fingirem chagas, ou outras enfermidades.

$4^{\circ}$ Quando mesmo invalidos mendigarem em reunião de quatro, ou mais, não sendo pai, e filhos, e não se incluindo tambem no numero dos quatro as mulheres, que acompanharem seus maridos, e os moços, que guiarem os cégos.

Penas - de prisão simples, ou com trabalho, segundo o estado das forças do mendigo, por oito dias a um mez.

183 BATISTA, Nilo. Apontamentos para uma história da legislação penal brasileira. Rio de Janeiro: Revan, 2016, p. 36.

${ }^{184}$ NEDER, Gislene. Iluminismo Jurídico-Penal Luso-Brasileiro. Obediência e submissão. 2 ed. Rio de Janeiro: Revan, 2007, p. 188.
} 
médico Luís Pereira Barreto afirmou que os abolicionistas não consideravam que o fim da escravidão faria surgir uma onda negra que despejava na sociedade "uma horda de homens semibárbaros, sem direção, sem um alvo social"185. Como já destacado acima, mesmo as posturas municipais intensificaram as suas previsões no período para lidar com essa nova realidade.

A visão do ser negro como inferior não era exclusiva daqueles que defendiam a permanência do regime escravocrata. Em verdade, permeava o pensamento de autores que se opunham à escravidão, justamente porque entendiam que essa prática trazia para o Brasil pessoas indesejadas.

Desse modo, a mais grosseira das perspectivas abolicionistas eram exatamente as vislumbradas por pessoas como João Severiano Maciel da Costa, José Eloy Pessoa da Silva, já referidos, mas também de sujeitos como os franceses Louis Couty e Arthur de Gobineau, que viam o negro como inábil para trabalhos duradouros e inteligentes, e entendiam que solução para o Brasil estava na imigração de brancos ${ }^{186}$ ou até mesmo no retorno da população negra para a África.

A geração seguinte a esses autores, a dos que ficaram efetivamente conhecidos como abolicionistas, também temia a voracidade dos negros, mas entendiam que eles poderiam ser educados e treinados para a vida civilizada, após saírem da desgraça do cativeiro. O negro precisaria, então, ser integrado à ordem social. Neste sentido, algumas passagens de Joaquim Nabuco em "O abolicionismo" são bastante elucidativas, como a seguinte:

A escravidão não há de ser suprimida no Brasil por uma guerra civil, muito menos por insurreições ou atentados locais. (...) É, assim, no Parlamento e não em fazendas ou quilombos do interior, nem nas ruas e praças das cidades, que se há de ganhar, ou perder, a causa da liberdade. Em semelhante luta, a violência, o crime, o desencadeamento de ódios acalentados, só pode ser prejudicial ao lado que tem por si o direito, a justiça, a procuração dos oprimidos e os votos da humanidade toda ${ }^{187}$.

Que a escravidão fosse, finalmente, suprimida. Mas suprimida no Parlamento, sem modificação da estrutura social, sem protagonismo negro. Como destaca Clovis Moura, "a

\footnotetext{
${ }^{185}$ Apud AZEVEDO, Célia Maria Marinho de. Onda negra, medo branco: o negro no imaginário das elites do século XIX. 3 ed. São Paulo: Annablume, 2004, p. 58.

${ }^{186}$ SANTOS, Gislene Aparecida dos. A invenção do "ser negro": um percurso das ideias que naturalizaram a inferioridade dos negros. São Paulo/Rio de Janeiro: 2002, p. 103-104.

${ }^{187}$ NABUCO, Joaquim. [1883]. O abolicionismo. Petrópolis: Vozes, 2012, p. 28-29.
} 
classe senhorial manipula mecanismos reguladores novos e arma uma estratégia que consegue deslocar sutilmente o fim do escravismo das lutas dos escravos para o Parlamento"188.

Como se vê, o medo da onda negra era uma temática generalizada entre os mais e os menos conservadores, o que pode explicar o movimento que ensejou a criação do Código Penal de 1890.

Com a iminência da abolição, os debates sobre o destino dessa população se intensificaram. Na sessão legislativa da Câmara dos Deputados de 9 de maio de 1888, Alfredo Chaves esboçava preocupação com o pós-abolição:

O projeto [de abolição] nas condições em que se acaba é também uma ameaça iminente à ordem pública, porque não se tomaram precauções para garantir a sociedade contra essa classe de cidadãos novos que a ela são atirados, sem os meios, siquer, de proverem a sua subsistência ${ }^{189}$.

Célia Marinho de Azevedo destacou ter sido essa a tônica também dos debates da Câmara Provincial de São Paulo. Fazendo um estudo sobre os discursos dos deputados daquela província, proferidos na década de 1870, a autora observa um medo constante das revoltas, sublevações e crimes dos escravos:

Durante toda a década de 1870 os temas do negro livre e do imigrante ideal nortearam os debates dos deputados provinciais. Preocupados com a extinção da escravidão em futuro próximo, os representantes dos interesses paulistas travaram intensas e acaloradas discussões, visando solucionar a questão da substituição do escravo pelo trabalhador livre ${ }^{190}$.

Pouco mais de um mês após publicação da Lei Áurea, o ministro Antonio Ferreira Viana apresentou, na Câmara, um projeto de "Repressão da ociosidade"191. O projeto, de n. 33, previa a criação de estabelecimentos destinados à correção dos infratores dos termos de bem viver (em outras palavras, daqueles que praticavam os chamados crimes policiais) e casas de educação específica para os menores de 17 anos. Além disso, criava novas agravantes penais, dentre as quais a "embriaguez habitual" 192 .

\footnotetext{
${ }^{188}$ MOURA, Clovis. Sociologia do negro no Brasil. São Paulo: Editora Ática, 1988, p. 241.

${ }^{189}$ CÂMARA DOS DEPUTADOS. Anais. 1988, Tomo I, p. 59.

${ }^{190}$ AZEVEDO, Célia Maria Marinho de. Onda negra, medo branco: o negro no imaginário das elites do século XIX. 3 ed. São Paulo: Annablume, 2004, p. 107.

${ }^{191}$ O projeto de Ferreira Viana previa a criminalização de todas essas ilegalidades populares e foi apresentado alguns dias após a aprovação da Lei Áurea.

${ }^{192}$ CÂMARA DOS DEPUTADOS. Anais. 1988, Tomo 2, p. 19.
} 
O pacote não chegou a ser aprovado, mas o grosso de suas propostas seria consagrado no Código Penal Republicano de 1890, aprovado, no novo regime, antes mesmo de uma constituição.

O Código de 1890, assim como o de 1830, possui aspectos ambivalentes e contraditórios. De fato, é possível mencionar de antemão o Livro III do referido diploma, o qual prevê como contravenção uma série de ilegalidades populares a exemplo da vadiagem, da mendicância, da embriaguez (previsões contidas no também no Código antigo) e, como uma novidade republicana, da capoeiragem.

Porém, em seus demais dispositivos, o Código é bastante influenciado por concepções da Escola Clássica, como o livre-arbítrio e suas formas de responsabilização criminal, adota medidas como o livramento condicional, nulidade processuais, o júri, dentre outros. Como lembrou Alvarez:

O Código Penal de 1890, com sua concepção notadamente clássica, em termos das doutrinas penais, representou, apesar dos dispositivos anteriormente citados, voltados para a repressão e o controle social de determinados segmentos da população, sobretudo uma ruptura com as práticas penais do passado escravista, ao instituir a generalidade e a imparcialidade dos critérios penais ${ }^{193}$.

Tanto é assim que o Código é rejeitado por muitos juristas, sobretudo os de tendência positivista. Na Escola do Recife e no principal veículo de publicação de seus autores, a Revista Acadêmica da Faculdade de Direito do Recife, a tônica será dada pelos integrantes da “Nova Escola Penal”. Para esses autores, o novo código não estava antenado à mais recente ciência, leia-se, o positivismo criminológico e, notadamente, a Escola Italiana, que, com o seu determinismo biológico ou social, nega o livre-arbítrio.

Ainda como exemplo dessa reação ao Código de 1890, merece destaque a obra Germens do crime, de Aurelino Leal, publicada em 1896. Nela, o autor apresenta aspectos da legislação penal brasileira que seriam responsáveis pela proliferação do crime: o júri, as nulidades e a prescrição - instrumentos basilares das reformas penais e processuais penais modernas. Segundo Leal, os legisladores precisariam atentar para os avanços da moderna ciência positivista e olhar mais detidamente "as camadas sociais, para estudar-lhes a higiene,

193 ALVAREZ, Marcos César. Bachareis, criminologistas e juristas: saber jurídico e Nova Escola Penal no Brasil. São Paulo: IBCCRIM, 2003, p. 71. 
o meio, a educação, a índole, o movimento do mundo psicológico de cada um; nega-lhes o livre-arbítrio em nome da físio-psicologia"194.

No mesmo sentido, Paulo Egídio falará em um “código impossível”, porquanto seria um diploma legal sem sistematicidade, sem fundamento teórico sólido ${ }^{195}$.

Assim, o Código de 1890 não contemplava as concepções da criminologia positivista e, por isso, foi alvo de muitas críticas e desacreditado pelos penalistas e criminólogos do período.

Porém, mesmo que aparentemente inviável, tributário de teses da Escola Clássica e refratário a algumas verdades apregoadas pelo positivismo criminológico, o Código não deixou de cumprir o seu papel como instrumento hábil à administração da circulação de pessoas nas ruas das cidades. Isso porque uma coisa eram os debates acadêmicos e dos intelectuais; outra completamente diferente era o que se dava nas ruas, sob a autoridade policial, que não precisava de muitos dispositivos do Código Penal ou do Código de Processo Penal, porque, ali, o espaço era o de sua soberania.

Para o embasamento das práticas policiais bastava mesmo o Livro III e suas contravenções, cuja repressão representava a maior parte das atividades policiais no Rio de Janeiro, como demonstrado na tabela 5, e no Recife, como destacarei no próximo capítulo. Assim, não era pouca coisa. Cerca de cinco artigos daquele livro, com redações abertas e previsões amplas, já foi a carta branca dada à polícia para lidar, no dia a dia, com os bairros pobres e negros das cidades brasileiras.

Portanto, embora bastante criticado pela intelectualidade positivista da época, o Código e outras leis extravagantes foram suficientes para autorizar a manutenção de um padrão de controle policial baseado na repressão às classes populares. Nilo Batista conclui que aquele diploma

espelha, com evidência didática, as contradições de um sistema penal que participa decisivamente da implantação da ordem burguesa porém traz consigo, e reluta em renunciar a ela, a cultura da intervenção corporal inerente ao escravismo. Esquematicamente, poderíamos ensaiar uma descrição das estratégias de tal sistema penal a partir da própria concepção, cara ao positivismo e por sua iniciativa inscrita na bandeira republicana, de ordem $^{196}$.

\footnotetext{
${ }^{194}$ LEAL, Aurelimo. Germens do crime. Bahia: Livraria Magalhães, 1896, p. v.

195 Apud, ALVAREZ, Marcos César. Bachareis, criminologistas e juristas: saber jurídico e Nova Escola Penal no Brasil. São Paulo: IBCCRIM, 2003, p. 70.

196 BATISTA, Nilo. Apontamentos para uma história da legislação penal brasileira. Rio de Janeiro: Revan, 2016, p. 84-85.
} 
Além do livro III e suas contravenções, a outra carta branca era dada às forças policiais pelo processo penal e seus silenciamentos, como já visto, mas também suas disposições que, ao longo do século XIX e início do século XX, oscilaram em dar mais ou menos autonomia às polícias, dificultando a criação de uma organização que se sentisse efetivamente subordinada à lei. Como destacam Zaffaroni, Batista, Alagia e Alokar, "o fracasso do projeto liberal ganha mais visibilidade nas fontes que se ocupam da própria organização do sistema penal, com ênfase no processo criminal"197 e a ele dedico o próximo tópico.

\subsection{A SOBERANIA POLICIAL E A LEGISLAÇÃO PROCESSUAL PENAL}

Além da programação criminalizante contribuir enormemente para a gestão penal das pessoas nas cidades, a legislação processual penal cumpre um papel fundamental ao distribuir competências, atribuições e funções às diversas agências do Estado Punitivo e estabelecer regras de processamento e julgamento. Como mencionado acima, são as regras de organização do sistema penal.

Neste ponto, vou me dedicar a compreender como essa legislação lidava com as polícias judiciária e administrativa.

Um dos temas que ocupou os processualistas entre os séculos XIX e XX foi o da separação entre as funções de polícia e a judicatura e ele está diretamente relacionado à problemática da soberania policial. Desde a organização da Intendência Geral de Polícia em Lisboa, ainda no final do século XVIII, uma confusão entre essas duas tarefas teria permitido o surgimento de policiais juízes e juízes policiais. João Mendes de Almeida recupera essa história e cita a existência de um Alvará de 15 de janeiro de 1780 que permitia ao Intendente Geral "prender pessoas que o merecessem conservando-as na prisão pelo tempo que julgar proporcional à desordem que tiverem cometido e lhe parecer necessário para a emenda" 198 . Essa disposição teria perdurado até 1825 , quando se criou, no Distrito Federal, a figura dos Comissários de Polícia, cuja responsabilidade seria a de investigar crimes e remeter as informações em seguida a juízes.

${ }^{197}$ ZAFFARONI, E. R.; BATISTA, N; ALAGIA, A.; SLOKAR, A. Direito penal brasileiro - I. Rio de Janeiro: Revan, 2006, p. 426.

198 ALMEIDA JR, João Mendes de. O processo criminal brazileiro. Vol. I. 3 ed. Rio de Janeiro: Typ. Baptista de Souza, 1920, p. 283. 
Em 1824, a Constituição do Império previu a criação da figura do Juiz de Paz ${ }^{199}$, uma autoridade local, eleita e leiga, que exerceria amplos poderes desde a vigilância da população, até a prisão e julgamento dos infratores pelos chamados "crimes de alçada" ${ }^{200}$. Era então, o oposto do que se tinha antes, tratava-se, agora, de um juiz policial. A lei de 15 de outubro de 1827 instituiu oficialmente o cargo de juiz de paz e efetivamente atribuiu a ele funções policiais, o que se repetiu com o Código de Processo Criminal de 1832. Este determinava que haveria um juiz de paz em cada distrito e lhes atribuía, dentre outras, funções de gestão do espaço público com o controle sobre a circulação de pessoas. Essa finalidade era cumprida, sobretudo, pela possibilidade de eles emitirem os chamados "termo de bem viver" e "termo de segurança"201.

No anexo 6, consta a organização da Justiça disposta no Código de Processo Criminal de 1832 e, como lá expresso, é possível verificar que, além dos juízes de paz, havia, em cada termo, juízes municipais e Conselhos de Jurados e, em cada Comarca, juízes de Direito. Nas comarcas mais populosas, o número de juízes de direito podia chegar a três, sendo que um deles assumia a função de Chefia de Polícia, cujas atribuições foram definidas no Decreto de 29 de março de 1833 e que eram muito discretas frente ao poder dos juízes de paz.

Como se percebe da leitura do artigo 12 do Código de Processo Criminal de 1832, vadios, prostitutas, bêbados por hábito ou suspeitos da pretensão de cometer algum crime poderiam ser obrigados a assinar o compromisso de boa conduta e, se descumprissem, ficariam sujeitos a uma pena imposta pelo próprio juiz de paz. O Código de 1832, nos artigos 205 a 212, regulava o procedimento nesses casos dos crimes de alçada e determinava que o processo poderia se iniciar através de denúncia ou de queixa, mas também ex-officio. Além desses crimes, essa autoridade também processava e julgava as infrações às posturas municipais ${ }^{202203}$, que, como visto no ponto anterior, também compunham o arcabouço de

\footnotetext{
${ }^{199}$ Segundo Diógenes Valle, a inspiração para a criação do juiz de paz veio da legislação francesa, que distinguia as infrações penais em contravenções, delitos e crimes. Para as primeiras, reservava um processo sumário e a cargo dos chamados juízes de polícia ou juízes de paz. VALLE, Diógenes Pereira do. Dos processos policiais. São Paulo: EGR, 1928, p. 11.

${ }^{200}$ De acordo com o Código Criminal de 1830, eram crimes dessa natureza: ofensas da religião, da moral e bons costumes, as sociedades secretas, ajuntamentos ilícitos, vadiagem, mendicância, uso de arma, uso de nomes supostos e títulos indevidos e outros. VALLE, Diógenes Pereira do. Dos processos policiais. São Paulo: EGR, 1928, p. 12.

${ }^{201}$ Sobre os termos, dispunha o CPCrim de 1832: Art. 12. Aos Juizes de Paz compete: $\S 2^{\circ}$ Obrigar a assignar termo de bem viver aos vadios, mendigos, bebados por habito, prostitutas, que perturbam o socego publico, aos turbulentos, que por palavras, ou acções offendem os bons costumes, a tranquillidade publica, e a paz das famílias. $\$ 3^{\circ}$ Obrigar a assignar termo de segurança aos legalmente suspeitos da pretenção de commetter algum crime, podendo cominar neste caso, assim como aos comprehendidos no paragrapho antecedente, multa até trinta mil réis, prisão até trinta dias, e tres mezes de Casa de Correcção, ou Officinas publicas.

202 Art. 12. Aos Juizes de Paz compete: $\S 7^{\circ}$ Julgar: $1^{\circ}$ as contravenções ás Posturas das Camaras Municipaes: $2^{\circ}$ os crimes, a que não esteja imposta pena maior, que a multa até cem mil réis, prisão, degredo, ou desterro até
} 
normas criadas para a vigilância e repressão das populações pobres e negras. Ainda, era frequente a emissão de Avisos estendendo as incumbências dos juízes de paz, a exemplo de um Aviso Circular de 26 de abril de 1836, emitido pelo Imperador, determinando que eles deveriam recolher meninos órfãos de pais e de mães que se entregassem à vida ociosa e os encaminhassem ao arsenal da Marinha ${ }^{204}$.

O conjunto de tarefas que podiam cumprir - investigar, acusar, processar e julgar permite concluir que as funções dos juízes de paz eram ligadas ao controle do espaço urbano e das "ilegalidades populares". Segundo Holloway, o juiz de paz é uma figura associada à necessidade de controle de escravos fugidos e libertos, que, frequentemente, confundiam-se nas cidades $^{205}$.

O poder punitivo, com os juízes de paz, concentrava-se em uma autoridade local, que, eleita, estava diretamente ligada às forças políticas dominantes nas províncias. Para Bretas, o código de processo criminal

é um dos estatutos legais mais importantes para representar o pensamento político dominante no período. Ao contrário das tendências da década de 1820 , ele procurou fortalecer os poderes locais, concentrando autoridade nas mãos dos juízes de paz eleitos ${ }^{206}$.

Porém, esse excesso de atribuição de poder às autoridades locais passou a representar uma preocupação para o Império, sobretudo após alguns levantes independentistas, como a Confederação do Equador, em Pernambuco, em 1824. Pouco a pouco, foram as atribuições dos juízes de paz recuadas. Já em 1835 um projeto de lei de autoria do Senador Alves Branco propunha a perda dos poderes policiais dos juízes de paz ${ }^{207}$. Um Aviso de 10 de junho de 1837 os proibia de mandar açoitar escravos sem que, antes, tivessem-no processado e julgado com a audiência do seu senhor.

Neste cenário, o Código de Processo Criminal de 1832 sofreu diversas reformas ao longo dos anos, e, em 1841 e 1842, verificou-se certamente a mais conservadora delas. A lei

seis mezes, com multa correspondente á metade deste tempo, ou sem ella, e tres mezes de Casa de Correcção, ou Officinas publicas onde as houver. (grifos nossos)

${ }^{203}$ A disposição do Código de Processo Criminal de 1832 era praticamente a repetição da Lei de 6 de junho de 1831, que estabelecia a competência dos juízes de paz para lidar com os crimes de alçada.

${ }^{204}$ NASCIMENTO, Josino do. Código do Processo Criminal de Primeira Instância do Império do Brasil. 6 ed. TOMO I. Rio de Janeiro: Eduardo \& Henrique Laemmert, 1870, p. 27.

${ }^{205}$ HOLLOWAY, Thomas H. Polícia no Rio de Janeiro: repressão e resistência numa cidade do século XIX. Rio de Janeiro: Editora FGV, 1997, p. 63.

206 BRETAS, Marcos Luiz. Ordem na cidade: o exercício cotidiano da autoridade policial no Rio de Janeiro: 1907-1930. Rio de Janeiro: Rocco, 1997, p. 42.

${ }^{207}$ ALMEIDA JR, João Mendes de. O processo criminal brazileiro. Vol. I. 3 ed. Rio de Janeiro: Typ. Baptista de Souza, 1920, p. 192. 
$\mathrm{n}^{\mathrm{o}} 261$, de 3 de dezembro de $1841^{208}$ e o Regulamento 120 de 1842 puseram em xeque alguns direitos liberais já consagrados naquele diploma legal. Primeiramente, a referida lei passou a competência dos juízes de paz para os chefes de polícia e delegados - a polícia judiciária, que se definia como tal a partir desse momento-, inclusive podendo estes emitir os termos de bem viver e de segurança ${ }^{209}$. Os chamados crimes de alçada passavam a ser chamados de "crimes policiais", denominação que perdurou ao longo do início do século XX.

Ainda, o regulamento 120 , nos artigos $2^{\circ}$ e $3^{\circ}$, estabeleceu claramente a divisão entre polícia administrativa e judiciária, conferindo àquela, dentre outras, a atribuição de reprimir ébrios, vadios, vagabundos, menores e prostitutas escandalosas, vigiar sociedades secretas, evitar ajuntamentos ilícitos, julgar as infrações às posturas municipais (!) e garantir a ordem pública. Já à polícia judiciária competia proceder a corpo de delito, prender culpados, conceder mandados de busca e apreensão e julgar os "os crimes, a que não esteja imposta pena maior que multa até $10 \$ 000$, prisão, degredo, ou desterro até seis mezes com multa correspondente á metade desse tempo, ou sem ella, e tres mezes de Casa de Correcção, ou officinas publicas, onde as houver". Esse alargamento das atribuições policiais era justamente ao que Faoro se referia como "policialismo judicial" 210.

À época dos debates, membros do partido Liberal bravejavam pela não aprovação da reforma. Alvares Machado, liberal e monarquista, afirmava: "parece que os meus colegas entendem que restringindo liberdades, evitarão crimes e desordens"211. Moura Magalhães também se opunha: "Um código firmado nos princípios da sã filosofia, um código esclarecido pelos princípios da razão e da humanidade, exige que as funções da polícia estejam separadas das funções da formação da culpa e estas funções do julgamento" ${ }^{212}$.

Já os conservadores opunham-se aos juízes de paz e suas competências policiais, aduzindo que se tratavam de autoridades nomeadas pelos membros das Câmaras Municipais e, como tal, estavam ligados aos interesses deles. O à época Ministro da Justiça, Paulino de

\footnotetext{
${ }^{208}$ Um projeto redigido por Bernardo Pereira de Vasconcellos, que sofreu dura oposição do Partido Liberal e grande apoio do Partido Conservador.

${ }^{209} \mathrm{O}$ Art. $4^{\circ}$ da referida lei previu o seguinte: "Aos Chefes de Policia em toda a Provincia e na Côrte, e aos seus Delegados nos respectivos districtos compete: $\S 1^{\circ}$ As attribuições conferidas aos Juizes de Paz pelo art. $12 \S \S$ $1^{\circ}, 2^{\circ}, 3^{\circ}, 4^{\circ}, 5^{\circ}$ e $7^{\circ}$ do Codigo do Processo Criminal".

${ }^{210}$ FAORO, Raimundo. Os donos do poder: formação do patronato político brasileiro. 5 ed. São Paulo: Globo, 2012, p. 276.

${ }^{211}$ Apud ALMEIDA JR, João Mendes de. O processo criminal brazileiro. Vol. I. 3 ed. Rio de Janeiro: Typ. Baptista de Souza, 1920, p. 194.

${ }^{212}$ Apud ALMEIDA JR, João Mendes de. O processo criminal brazileiro. Vol. I. 3 ed. Rio de Janeiro: Typ. Baptista de Souza, 1920, p. 196.
} 
Souza, discursou favoravelmente à Lei 261 no dia 3 de novembro de 1841, utilizando-se justamente desse argumento ${ }^{213}$.

Apesar dos protestos, a referida lei foi aprovada e, com ela, garantido o centralismo desejado pelo Governo, já que, dentre outras mudanças, os chefes de polícia seriam nomeados pelos representantes do governo central na Província. Como destacou Bretas:

As frequentes revoltas e a instabilidade da década de 1830, alimentadas pelas disputas entre as elites, logo demonstraram os obstáculos à construção do estado nacional com base na ordem. A reforma do Código de Processo Criminal foi feita em 3 de dezembro de 1841, sob o patrocínio conservador, e buscava reduzir os poderes dos juízes eleitos, substituindo-os por uma estrutura nomeada pelo poder central de juízes profissionais e funcionários policiais ${ }^{214}$.

A lei ampliou as competências policiais, que lidaria, agora, em sua própria jurisdição, com a desordem pública. Embora os debates legislativos se concentrassem na dicotomia centralização versus descentralização, outro escopo era vislumbrado pelos parlamentares que aprovaram a reforma: controlar a desordem pública, popular e escrava que se espraiava pelo Brasil na primeira metade do século XIX.

Afirmei acima que a Síndrome do medo do negro norteou projetos de lei penal. Igualmente o fez em relação às leis processuais e, neste sentido, cumpre ressaltar alguns debates realizados na Câmara dos Deputados por ocasião da discussão da lei 2.033, que, em 1871, viria a superar as reformas de 1841 e 1842. Naquela Casa, em um discurso realizado em 13 de agosto de 1870, Theodoro Machado lembrava os parlamentares do duro contexto de "anarquia" que o Brasil vivia quando aquelas reformas na década de 1840 tinham sido suscitadas. As sublevações por ele lembradas envolvem a de escravos, como o caso do assassinato do presidente da província da Bahia, José Egídio Gordilho de Barbuda, o Visconde de Camamú ${ }^{215}$, que teria precisado enfrentar em seu governo vários levantes negros no fim da década de 1820, tendo ele sido assassinado em 1830.

O mesmo foi feito por Perdigão Malheiros, para quem o Código de 1832 privilegiava o componente democrático e a lei de 1841, o de autoridade, "porque as leis nascem de circunstâncias que as provocam”. Já o Deputado Matheus Casado - o único que estava na

\footnotetext{
${ }^{213}$ Apud ALMEIDA JR, João Mendes de. O processo criminal brazileiro. Vol. I. 3 ed. Rio de Janeiro: Typ. Baptista de Souza, 1920, p. 201.

${ }^{214}$ BRETAS, Marcos Luiz. Ordem na cidade: o exercício cotidiano da autoridade policial no Rio de Janeiro: 1907-1930. Rio de Janeiro: Rocco, 1997, p. 42.

${ }^{215}$ Apud ALMEIDA JR, João Mendes de. O processo criminal brazileiro. Vol. I. 3 ed. Rio de Janeiro: Typ. Baptista de Souza, 1920, p. 211.
} 
Câmara desde as reformas da década de 1840, na sessão de 23 de agosto de 1870, discursou: “a lei de 3 de dezembro tem sido atrozmente caluniada pelos seus adversários; entretanto se atendermos às circunstâncias do país naquela época, concluir-se-á infalivelmente que razões muito poderosas tiveram os legisladores daquele tempo" ${ }^{216}$, lembrando aos ouvintes que, no Pará, o presidente da província havia sido assassinado, e se remeteu expressamente à Sabinada, na Bahia, à Balaiada, no Maranhão, aos Cabanos, em Alagoas, dentre outras, todas revoltas protagonizadas por escravos e ex-escravos. O estado era, segundo ele, de "caos por toda parte".

Ampliando ainda mais as determinações da lei $\mathrm{n}^{\mathrm{o}} 261$, o Aviso de 16 de Novembro de 1849 previa que o processo que se instaurava para se obrigar a assinar termo de bem viver é equiparado com o da formação da culpa ${ }^{217}$.

Mas não veio a lei apenas para ampliar as atribuições policiais e fazer destes verdadeiros juízes. A lei no 261 era um grande pacote que previa: extinção do júri de acusação (restando apenas o júri de sentença), criação das apelações ex-officio das decisões dos juízes de direito e instituição do recurso de ofício da decisão que concedia a soltura em virtude de ordem de habeas corpus, previsão esta, aliás, contida até hoje em nosso Código de Processo Penal $^{218}$ !

A reforma conservadora passou a ser atacada veementemente pelos parlamentares liberais, já tendo surgido em 1845 projetos que se opunham a ela ${ }^{219}$. Foi, entretanto, entre 1869 e 1871 que se acaloraram intensos debates acerca das atribuições policiais e da necessidade de se afastar delas qualquer competência judicial. O "policialismo judicial" foi tema amplamente debatido nas sessões da Câmara dos Deputados, tanto na gestão do Ministro da Justiça José de Alencar, como no do seu sucessor, Sayão Lobato. Ali, as questões giravam em torno do que seria mais saudável em uma nação civilizada, estando a maioria dos deputados de acordo com a supressão de atribuição judiciais da polícia. Para José de Alencar, por exemplo, toda polícia seria meramente administrativa, limitando-se tão-somente às atividades preventivas e à coleta de indícios de autoria e materialidade para subsidiarem uma acusação formal na justiça.

\footnotetext{
${ }^{216}$ Apud ALMEIDA JR, João Mendes de. O processo criminal brazileiro. Vol. I. 3 ed. Rio de Janeiro: Typ. Baptista de Souza, 1920, p. 228.

${ }^{217}$ NASCIMENTO, Josino do. Código do Processo Criminal de Primeira Instância do Império do Brasil. 6 ed. TOMO I. Rio de Janeiro: Eduardo \& Henrique Laemmert, 1870, p. 126.

${ }^{218}$ Art. 574. Os recursos serão voluntários, excetuando-se os seguintes casos, em que deverão ser interpostos, de ofício, pelo juiz: I - da sentença que conceder habeas corpus;

${ }^{219} \mathrm{O}$ deputado Rodrigues dos Santos discursou na sessão de 4 de agosto de 1845: "A lei de 3 de dezembro ofende a Constituição, porque entrega o direito de processar o cidadão brasileiro a delegados de polícia amovíveis".
} 
O resultado foi que as atribuições dos chefes de polícia e delegados foram recuadas com a lei 2.033 e o decreto 4.824, ambos de 1871, que limitaram a atividade policial de investigação preliminar, estabeleceram prazo máximo para a finalização do inquérito ${ }^{220} \mathrm{e}$ impuseram limites à coleta de elementos de prova. O mais importante: retiraram dos chefes de polícia, delegados e subdelegados a prerrogativa de processar e julgar nos casos dos delitos policiais e as posturas municipais. A lei foi expressa nesse sentido:

Art. $9^{\circ}$ Fica extincta a jurisdicção dos Chefes de Policia, Delegados e Subdelegados no que respeita ao julgamento dos crimes de que trata o art. 12 $\S 7^{\circ}$ do Codigo do Processo Criminal, assim como quanto ao julgamento das infracções dos termos de bem viver e segurança, e das infracções de posturas municipaes.

Também no quesito relativo ao direito de liberdade ir e vir e ao habeas corpus, avançou a lei 2.033 ao criar o remédio preventivo, em seu artigo $18, \S 1^{\circ}$, que dispunha: “Tem lugar o pedido e concessão da ordem de habeas-corpus ainda quando o impetrante não tenha chegado a soffrer o constrangimento corporal, mas se veja delle ameaçado", embora alguns dos dispositivos da lei tenham permanecido antipáticos aos liberais, a exemplo do $\S 2^{\circ}$ do artigo 18, que impedia a impetração de habeas corpus contra a prisão determinada por despacho de pronuncia ou sentença da autoridade competente ${ }^{221}$.

Enfim, após 1871, delegados e subdelegados teriam perdido em definitivo poderes judiciais. Mas, a inquietude em torno dessa supressão de competência fez a polícia continuar a barganhar parte dessas prerrogativas depois em alguns estados.

Em São Paulo, a lei no 80 e o Decreto 123, ambos de 1892, permitiu que delegados e subdelegados instaurassem ex-officio processos judiciais em casos de contravenção. Porém, analisando a jurisprudência da época tanto do Tribunal de Justiça como do Supremo Tribunal Federal, Diógenes do Valle verificou que alguns processos iniciados pelas autoridades policiais acabaram por ser anulados sob a justificativa de que isso feria a separação de poderes

\footnotetext{
${ }^{220}$ Em 1917, na Conferência Judiciário Policial, João Mendes de Almeida Junior comentava sobre as inovações da Lei 2.033 de 1871 e ressaltava que os liberais, à época da reforma, buscavam evitar as longas devassas a que procedia a polícia na tarefa investigativa, sobretudo após as reformas sofridas pelo Código de Processo Criminal de 1832, em 1841 e 1942. Assim, a regulamentação do Inquérito Policial teria sido um importante avanço.

${ }^{221}$ A lei 2.033 foi ainda criticada por liberais quando estava sendo discutida no Senado, em virtude da redação do $\S 2^{\circ}$ do artigo 18 . Ele impedia a impetração de habeas corpus contra a prisão determinada por despacho de pronuncia ou sentença da autoridade competente. Pontes de Miranda comenta que José Tomás Nabuco de Araújo teria se contraposto a essa disposição, alegando, inclusive, que o Supremo Tribunal de Justiça teria concedido uma ordem de habeas corpus ao presidente do partido liberal, envolvido em um processo político em 1841 . À essa reclamação, o Ministro da Justiça, o Visconde do Abaeté, teria respondido, afirmando que, tratando-se de uma pronúncia ou sentença condenatória, não caberia falar em habeas corpus, mas em recursos ordinários. MIRANDA, Pontes de. História e prática do habeas corpus. TOMO I. Rio de Janeiro: Editor Borsoi, 1972, p. 137.
} 
disposta na Constituição de 1891 e algumas disposições do Código Penal de 1890, que somente permitia ação ex-officio nos casos de crimes inafiançáveis ${ }^{222}$.

Em 1899, foi a vez de o Distrito Federal elaborar uma legislação no mesmo sentido, a lei $n^{\circ} 628$ que, em seu artigo $6^{\circ}$ dispunha competir ao chefe de policia e delegados de polícia do Distrito Federal processar ex-officio algumas contravenções, incluindo a de vadiagem e as de jogos de azar. A lei foi um projeto de Alfredo Pinto, que, como destaquei no capítulo anterior, tornou-se um importante chefe de polícia do Distrito Federal praticamente uma década depois ${ }^{223}$.

Segundo ainda o artigo $6^{\circ}$ daquela lei, em poucos dias, o processo seria iniciado e desenvolvido pelas autoridades policiais. Ao final, seriam encaminhados à pretoria para serem julgados pelos juízes pretores. Como se vê, às autoridades policiais estava teoricamente vedado julgar.

Porém, muitas vezes os pretores julgavam o processo tão-somente com base nos autos encaminhados pela autoridade policial, sem a presença do acusado, o que merecia a crítica de alguns, dentre eles, Evaristo de Moraes $^{224}$. Havia uma recepção praticamente acrítica das informações colhidas em sede policial, que, na prática, constituía a verdadeira instância de julgamento ${ }^{225}$.

Com base nessas disposições, Lerice Garzoni pôde consultar os processos policiais desenvolvidos no Rio de Janeiro, no início do século XX, e verificar o que entendiam as partes envolvidas por "vadiagem" ou "trabalho". Garzoni chama atenção para o fato de que essas definições eram necessariamente diferentes quando se tratassem de presos homens ou mulheres, afinal, estas últimas estavam muito mais sujeitas a serem definidas por vadias quando seus comportamentos eram imorais ou ofensivos ao pudor público, exigência incomum para os homens, reforçando o componente de controle sexual que recai preferencialmente sobre mulheres ${ }^{226}$. Ao mesmo tempo, para mulheres, o simples fato de

\footnotetext{
222 VALLE, Diógenes Pereira do. Dos processos policiais. São Paulo: EGR, 1928, p. 15.

${ }^{223}$ Ele teve aquela clássica trajetória dos juristas da época. Foi deputado, chefe de polícia e, por fim, ministro do Supremo Tribunal Federal.

${ }^{224}$ GARZONI, Lerice de Castro. Nas fronteiras do não-trabalho: trabalhadoras pobres e as definições de vadiagem do início do século XX. Revista Mundo do Trabalho, v. 1, n, 2, 2009, p. 73.

225 Neste ponto, impossível não recordar os debates contemporâneos a respeito dos processos de tráfico de drogas e da prova testemunhal de policiais, que, em inúmeros casos, constitui o único elemento que subsidia condenações. Conferir: JESUS, Maria Gorete Marques de. O que está no mundo não está nos autos: a construção da verdade jurídica nos processos de crimes de tráfico de drogas. Tese de Doutorado. Programa de Pós-Graduação do Departamento de Sociologia da Universidade de São Paulo (FFLCH-USP). 2016.

${ }^{226}$ GARZONI, Lerice de Castro. Nas fronteiras do não-trabalho: trabalhadoras pobres e as definições de vadiagem do início do século XX. Revista Mundo do Trabalho, v. 1, n, 2, 2009, p. 69.
} 
“perambularem" pelas ruas, local, por excelência, masculino, colocava-as em situação de suspeição ${ }^{227}$.

Talvez isso explique a enorme suscetibilidade que as mulheres negras tinham de serem presas pela contravenção de vadiagem, mas, sobre isso, falarei melhor no próximo capítulo.

Por ora cumpre concluir que, no início da República e, inclusive por força da separação de poderes, não mais existiam prerrogativas judiciais por parte da polícia. Porém, apesar das vedações legais na maioria dos estados, no início do período republicano, na prática, a polícia continuava soberana nas ruas e, como demonstrado anteriormente, casos jurídicos ou não jurídicos, criminais ou não, continuavam a ser encaminhados às autoridades policiais e por elas resolvidos; os chefes de polícia continuavam a ter poderes amplos, inclusive de concessão de mandados de busca e de apreensão; as polícias judicial e administrativa permaneciam com ampla liberdade para, nas ruas, prender e soltar desordeiros ou qualquer outro "elemento" inconveniente.

Como permitir que à polícia fosse dada tal liberdade? Iniciei esse capítulo refletindo justamente sobre o relevante papel que os juristas em geral e o poder judiciário, em especial, poderiam cumprir ao interpretar conceitos e leis de maneira favorável às intervenções policiais. Aurelino Leal, chefe de policia do Distrito Federal, tanto sabia disso que, além dos contatos com esses juristas, teve a iniciativa de realizar a Conferência Judiciária-Policial de 1917, a qual eu dedico as próximas páginas.

\subsection{A CONFERÊNCIA JUDICIÁRIA-POLICIAL DE 1917}

A justiça e a polícia são instituições legais e minimamente conservadoras da ordem e da segurança públicas. Uma atende à solicitação que lhe fazem os direitos prejudicados; a outra vigia por que esses direitos não sejam atingidos. A aliança, pois, dessas duas organizações é indispensável ${ }^{228}$

Essas eram parte das palavras proferidas por Aurelino Leal no discurso de abertura da Conferência Judiciária-Policial, ocorrida entre os dias 3 de maio e 9 de agosto de 1917. O encontro contou com a participação de policiais, notadamente chefes de polícia e peritos, membros do Ministério Público, juristas renomados e magistrados, incluindo cinco ministros do Supremo Tribunal Federal: Leoni Ramos, João Mendes Junior, Viveiros de Castro, André

227 GARZONI, Lerice de Castro. Nas fronteiras do não-trabalho: trabalhadoras pobres e as definições de vadiagem do início do século XX. Revista Mundo do Trabalho, v. 1, n, 2, 2009, p. 82.

${ }^{228}$ LEAL, Aurelino. Annaes da Conferência Judiciária-Policial de 1917. V. 2. Rio de Janeiro: Imprensa Nacional, 1918, p. 19. 
Cavalcanti e Godofredo Cunha. Na abertura, o presidente da República Wenceslau Braz Pinto e da província do Distrito Federal, Nilo Peçanha, faziam-se também presentes.

A organização da Conferência ficou a cargo do então Chefe de polícia do Distrito Federal, Aurelino Leal, cujo percurso intelectual e profissional vale a pena rapidamente resgatar, pois é, por certo, alguém que percorreu uma trajetória típica dos homens brancos e juristas de seu tempo. Era filho de um fazendeiro e coronel no Estado da Bahia, formou-se em Direito pela Faculdade daquele estado, desempenhou as funções de promotor público, escreveu em jornais, foi presidente de uma penitenciária e, finalmente, no final do século XIX, tornou-se Chefe de polícia do seu estado natal. Em 1986, publicou uma obra intitulada “As religiões entre os condenados na Bahia". Em 1912, Aurelino se mudou para o Rio de Janeiro e, em 1914, foi nomeado como Chefe de polícia do Distrito Federal, ocupando o cargo até 1918.

Na Chefia de Polícia do Distrito Federal, ele foi bastante ativo nas articulações pela reforma das forças policiais e era um defensor da autonomia dos chefes de polícia, entendendo que, assim, a repressão à delinquência seria feita de forma mais organizada. Ao mesmo tempo, também entendia ser imprescindível uma polícia de carreira, em que os agentes fossem progredindo paulatinamente. Como destacou na Tese defendida na Conferência,

É preciso que o funcionário, ao alistar-se no serviço de segurança da cidade, ainda moço e cheio de vida, tenha a esperança de melhores dias, porque ele os vai passar maus no exercício do seu cargo. A função do policial é antipática ao povo, com o qual tem que lutar nos seus desvios. Por outro lado, é mal remunerada e cheia de perigos ${ }^{229}$

Além de emplacar uma campanha pelas reformas, Aurelino também nutriu conversas com o Poder Judiciário e a Conferência é certamente um fruto dessa articulação. Após deixar o cargo de Chefe de polícia, Aurelino ainda foi membro do Ministério Público novamente, interventor federal no Rio de Janeiro em 1923 e, no ano seguinte, elegeu-se deputado federal pelo seu estado de origem. Foi, enfim, professor de direito constitucional, diretor de jornais (O Regenerador, na Bahia e Diário de Notícias, no Distrito Federal) e escritor, tendo publicado obras em criminologia como "Os germens do crime" e "Polícia e Poder de Polícia", esta última um resultado dos debates ocorridos da Conferência. Enfim, ao longo de sua vida, Aurelino ocupou cargos de poder estratégicos e se tornou um formador de opinião.

${ }^{229}$ LEAL, Aurelino. Tese I. Seção I. Annaes da Conferência Judiciária-Policial de 1917. Vol. I. Rio de Janeiro: Imprensa Nacional, 1918, p. 12. 
Como organizador da Conferência, Aurelino escolheu os temas a serem abordados nas teses, os autores de cada uma delas e, ao longo dos encontros, participou ativamente da formulação da redação final que seria publicada. Foi, certamente, o maior mentor dos Anais.

Dentre as temáticas escolhidas, todas tinham por principal objeto a manutenção da ordem e da segurança públicas. O que fazer com o jogo do bicho, a vadiagem, a prostituição, os acidentes de trânsito, os menores abandonados, os operários associados e insurgentes? Como organizar a polícia de modo a aprimorar o seu trabalho? Como o judiciário poderia contribuir com essa tarefa?

Aurelino Leal, no discurso de inauguração da Conferência, apontou para os quatro objetivos daquela reunião: a) estreitar os laços de harmonia entre os membros da magistratura e as autoridades policiais; b) discutir a organização geral do serviço de polícia do Distrito Federal; c) esclarecer as questões limítrofes ou de interesse comum à justiça e à polícia e d) traçar com a possível clareza a linha de ação legal da polícia, diminuindo as possibilidades do poder arbitrário.

Para o chefe de polícia, a polícia e a justiça precisariam afinar suas práticas, a fim de combater da forma mais eficaz a criminalidade. Ele deu o exemplo de sua própria atuação no Rio de Janeiro em relação à vadiagem e o quanto a união com o poder judiciário teria sido imprescindível para reduzir a impunidade em relação àquele crime.

Segundo Aurelino, no ano de 1906, apenas 422 vagabundos teriam sido condenados e, com frequência, prisões realizadas pela polícia eram relaxadas ou revogadas por meio de concessões de habeas corpus. Inconformado, o chefe de polícia teria procurado representantes da Corte de Apelação do Distrito Federal, dentre os quais o desembargador Celso Aprígio Guimarães, solicitando apoio daquele poder e também do Ministério Público na repressão à vadiagem, o que demandaria cautela na concessão das ordens de soltura. Segundo Aurelino, o seu apelo foi atendido e as condenações por vadiagem teriam crescido exponencialmente.

Com essa postura cooperativa entre polícia e justiça, a polícia do Distrito Federal teria obtido importantes vitórias no poder judiciário como decisões considerando válidas as providências contra o meretrício, admitindo o poder regulamentador do chefe de polícia, justificando as atividades de vigilância de organizações operárias, admitindo a repressão a determinados cultos religiosos e tantas outras.

Portanto, a expectativa com a realização da Conferência era a de que esses laços pudessem se estreitar ainda mais e que os benefícios daí advindos fossem se alastrando Brasil afora. Afinal, no que diz respeito ao arsenal criminalizador brasileiro, que previa como delito 
boa parte das condutas entendidas à época como ofensivas à ordem pública, a polícia não poderia se queixar; não faltavam tipos penais e contravencionais, como expus acima.

Porém, diante de uma ordem constitucional liberal e das reformas nas leis de processo que reduziram as atribuições policiais, como permitir que essas forças executassem sua tarefa investigativa e, sobretudo, preventiva, gozando de certa discricionariedade e atuando juridicamente, isto é, conforme o direito? Seria preciso aprovar um programa de defesa social compatível com o ordenamento jurídico brasileiro e a polícia contava com a autorização dada pelo poder judiciário através de interpretações dos textos constitucional e legal favoráveis a suas práticas. Como comentei no primeiro capítulo, as forças policiais procuram a legitimidade no direito para os seus atos, razão pela qual esse posicionamento do campo jurídico é fundamental.

O foco então estava no tema das liberdades e do poder de polícia. Como harmonizálos? Leal afirmava em seu discurso que era preciso entender de uma vez por todas que "não há liberdades livres, há liberdades jurídicas" ${ }^{230}$. Sendo assim, não se tratava de um direito absoluto. Ao contrário, à polícia caberia restringir a liberdade quando ela se tornasse perniciosa à ordem pública e a outros indivíduos.

Para tratar dessa temática, Aurelino escolheu o Ministro do Supremo Tribunal Federal, Viveiros de Castro. Conservador, Castro certamente não decepcionaria Aurelino Leal em sua exposição, afinal, era preciso "sair daqui, meus senhores, a doutrina da orientação conservadora, que é preciso adotarmos em nome do nosso futuro!" 231 , bradejava o orador de sessão de abertura da Conferência.

A Conferência, portanto, destinava-se a criar teses jurídicas para amparar a atuação policial e justificador suas práticas. Embora nem todos os participantes tivessem o mesmo perfil, é interessante verificar como as temáticas centrais ficaram a cargo dos magistrados mais conservadores e do próprio Aurelino, como é caso das teses sobre liberdades individuais, poder de polícia, vigilância nas ruas e prostituição.

Os debates acabaram se dividindo em três seções: a primeira sobre organização da polícia, presidida pelo Desembargador Edmundo de Almeida Rego; a segunda se intitulava "Justiça e Polícia" e era presidida por Viveiros de Castro e a terceira seção era sobre Polícia Administrativa e foi coordenada por Pedro Augusto Carneiro Lessa. No anexo 7 consta a relação de cada uma das teses aprovadas na conferência e seu respectivo autor.

${ }^{230}$ LEAL, Aurelino. Annaes da Conferência Judiciária-Policial de 1917. V. 2. Rio de Janeiro: Imprensa Nacional, 1918, p. 20

${ }^{231}$ LEAL, Aurelino. Annaes da Conferência Judiciária-Policial de 1917. V. 2. Rio de Janeiro: Imprensa Nacional, 1918, p. 23. 
Se eu pudesse exprimir uma tendência principal dos debates realizados na Conferencia, diria que se tratou de um elogio à defesa social e uma crítica aos excessos do liberalismo.

Pedro Tórtima trabalhou a Conferência Judiciária-Policial e a leu como um instrumento em que as classes dominantes teriam reunido esforços para reprimirem com maior eficácia os levantes de operários, bastante frequentes no período e, inclusive, no ano de 1917. Para Tórtima era indubitável que "a legislação de controle da força de trabalho constituía-se em poderoso instrumento de dissuasão do movimento operário. Aurelino e seus confrades da Conferência tinham perfeita consciência dessa arma hábil do Estado"232. Porém, não apenas a repressão era visualizada como possível, mas também o paternalismo. Assim, no balanço feito pelo historiador, teria a Conferência se dedicado a pensar repressão e assistência às classes operárias, em ambos os casos, visando à pacificação social e à disciplina dessa categoria.

De fato, ao longo do evento, foram debatidas trinta e uma teses e aprovadas vinte e sete, muitas das quais abordando direta ou indiretamente a questão operária. Porém, a tônica da Conferência era a desordem pública, conceito mais amplo do que a subversão operária, mas, certamente, atrelado sempre a este. No próximo capítulo, trabalharei a hipótese de que o projeto civilizacional, forte naquele período, era refratário a um conjunto de ilegalidades que se justapõem e se constroem mutuamente: uma desordem de classe, de raça e de gênero. Desse modo, não foi incomum ler, naqueles autores, os estrangeiros anarquistas serem definidos como cafetões ou as mulheres operárias, como degeneradas sexualmente. O desvio ao modelo representado na imagem do homem branco e proprietário torna a imagem da desordem aquele conjunto de pessoas abordadas na Conferência: prostitutas, mendigos, vagabundos, jogadores, operários etc.

Que temática poderia contemplar todo esse grupo de "desordeiros"? As leis penais já lidavam com cada um deles e as processuais penais, ao longo do século XIX e início do XX, os trataria como uma questão de polícia, como já explicitado acima. O espaço da Conferência seria agora o de firmar interpretações, discutir lacunas, estabelecer os limites e as possibilidades do poder policial.

Não por acaso, o tema do Poder de Polícia foi objeto de uma tese específica, a VII da Seção I, escrita por Aurelino Leal. Suas principais referências no campo do poder de polícia

\footnotetext{
${ }^{232}$ TORTIMA, Pedro. Polícia e justiça de mãos dadas: A conferência Judiciário-Policial de 1917. Dissertação de Mestrado. Instituto de Ciências Humanas e Filosofia. Centro de Estudos Gerais. Universidade Federal Fluminense, 1988, p. 183.
} 
eram o alemão Otto Mayer e o italiano Ranelletti, citados frequentemente nos seus textos e discursos. No campo criminológico, Aurelino bebia da fonta tradicional de sua época: o positivismo italiano.

No geral, Aurelino entendia que o poder de polícia, dada a complexidade do cotidiano nas ruas, estaria inevitavelmente envolto de uma discricionariedade dos agentes policiais, que, diante de algumas situações não previstas em lei, teriam a liberdade de realizar um juízo de conveniência e de oportunidade. Além disso, o autor defendia o poder regulamentar dos Chefes de Polícia, considerando que a Constituição de 1891, ao permitir aos presidentes a regulamentação de leis, teria, também, admitido aos auxiliares do executivo essa tarefa ${ }^{233}$.

Era exatamente esse aspecto o mais polêmico. Poderiam policiais, mesmo os chefes de polícia, legislar? Ao redigir a tese, Aurelino expôs vários pontos, mas três deles receberam oposição dos relatores do trabalho. Eram os seguintes:

III - O poder de polícia deve, principalmente, assentar na lei. O princípio é que, tanto quanto possível, tudo deve ser determinado por uma regra de direito - lei de polícia ou regulamento de polícia.

VIII - O poder de polícia compreende as penas de polícia. Estas são diferentes das inscritas no Código Penal, porque revê stem de um caráter puramente administrativo. Os fatos punidos com tais penas são meras contravenções administrativas ou delitos administrativos que escapam ao conceito de dolo e culpa.

IX- O poder de polícia, no domínio dos fatos, se realiza por penas coercitivas, por substituição e pela força. Toda a ação coercitiva deve ser regulada nas leis e regulamentos. A coerção por substituição, embora desconhecida no nosso direito, pode ser por ela adotada e está contida na lei 3232 de 1917.

O ministro Guimarães Natal, relator do parecer, entendia que as três teses acima eram incompatíveis com preceitos da Constituição de 1891, basicamente por permitir ao executivo, na figura da polícia, a prerrogativa de legislar e instituir penas, escolhendo as condutas que constituíam uma ofensa à ordem pública. A carta constitucional teria consagrado a divisão de poderes e, com ela, a excepcionalidade das atribuições legislativas do poder executivo, o que impediria um chefe de polícia criar normas de circulação nas cidades, por exemplo ${ }^{234}$.

\footnotetext{
233 As discussões giraram em torno do artigo 48, 1 da Constituição de 1891, que dispunha: "Compete privativamente ao Presidente da República: $1^{\circ}$ ) sancionar, promulgar e fazer publicar as leis e resoluções do Congresso; expedir decretos, instruções e regulamentos para sua fiel execução" (grifo nosso).

${ }^{234}$ ATA DA QUARTA REUNIÃO DA I SEÇÃO. Annaes da Conferência Judiciária-Policial de 1917. Vol. II. Rio de Janeiro: Imprensa Nacional, 1918, p. 116.
} 
Porém, essa prática era largamente realizada pela polícia. No próximo capítulo, destacarei que a administração da prostituição coube basicamente à polícia naquele período, que determinava, por meio de regulamentos, nas cidades, onde a atividade poderia se exercer, o horário e a forma. Ao mesmo tempo, a polícia também determinava acerca de jogos, de meetings operários. Desse modo, Aurelino parecia apenas barganhar apoio para uma prática que já era corriqueira.

Nas sessões em que ocorreram os debates, Viveiros de Castro saiu em defesa da tese de Aurelino:

o domínio da função regulamentar compreende, assim, a preexistência de uma lei ou a espontaneidade na sua falta do Poder executivo cabendo ao chefe de Estado exercê-la diretamente ou pelos seus ministros e funcionários mais elevados, entre os quais o chefe de polícia ${ }^{235}$.

A única emenda que Castro sugeriu foi no ponto III, que deveria contar, segundo ele, com a seguinte redação: "Quanto aos fatos puníveis, a lei escolhe ou deixa que o Poder Executivo escolha as perturbações que se lhe afiguram bastante importantes para dar-lhes sanção penal". Assim, deixava explícita a proibição de a polícia criar tipos penais, embora admitisse que ela criasse tipos administrativos. A proposta de Castro foi aceita à unanimidade de votos.

O Ministro Pedro Lessa, mesmo não comparecendo à sessão que discutiu a tese, encaminhou uma carta em apoio a Aurelino, que a leu na sessão ${ }^{236}$. Na carta, o ministro coadunava com todos os termos da tese do elaborador, a qual foi, ao final, após um longo debate, aceita e publicada.

Outra tese que tratou indiretamente da temática do poder de polícia foi a VII, da terceira seção, redigida por Celso Vieira de Mello Pereira, que chegaria a ser chefe de polícia do Distrito Federal. O trabalho abordou o tema da circulação das pessoas nas ruas e isso estava totalmente relacionado à extensão do poder de polícia. No caso, defendia o autor a possibilidade de a polícia administrativa intervir sobre atividades como o meretrício, o jogo de azar, a embriaguez, a decência pública, os maus tratos aos animais ${ }^{237}$, a mendicidade, o disfarce de sexo ${ }^{238}$, a vadiagem e o trânsito, regulamentando-as quando a lei fosse silente.

\footnotetext{
235 ATA DA QUARTA REUNIÃO DA I SEÇÃO. Annaes da Conferência Judiciária-Policial de 1917. Vol. II. Rio de Janeiro: Imprensa Nacional, 1918, p. 117.

${ }^{236}$ ATA DA QUARTA REUNIÃO DA I SEÇÃO. Annaes da Conferência Judiciária-Policial de 1917. Vol. II. Rio de Janeiro: Imprensa Nacional, 1918, p. 121-122.

237 Curiosa a menção a esse tipo de situação. O autor destaca que, aos poucos, o direito brasileiro estaria contemplando regras civilizatórias e que demonstram sentimento de proteção aos animais, impedindo que a eles
} 
Noutro momento, o meretrício recebeu especial atenção da Conferência em mais uma tese redigida por Aurelino Leal, a tese III da terceira seção. Nela, o autor destacava a possibilidade de a polícia determinar onde o meretrício poderia ser praticado, prática esta bastante corriqueira, conforme aprofundarei no capítulo seguinte. Leal mencionou no trabalho, inclusive, precedentes do STF que julgaram válidos os regulamentos expedidos por chefias de polícia no intuito de organizar a atividade em apreço, deixando evidente que já havia amparo judicial para aquelas ações ${ }^{239}$.

Já o Desembargador Antônio Ferreira de Souza Pitanga, na Tese IV da terceira seção, defendeu o direito de a polícia administrativa internar loucos e menores. O magistrado inicia o seu trabalho afirmando que ele não é científico, mas baseado em sua larga experiência e defende a criação de centros de internamento de loucos e menores que representem um risco à vida em sociedade. Sem esses centros, a assistência policial careceria de alternativas para encaminhar indivíduos que fossem encontrados naqueles estados, aos quais não se poderia reservar apenas a repressão, mas também a assistência:

A creação de asylos, de orfanatos, de creches para as mães operarias, de colônias agrícolas para os que possam exercer alguma atividade reprodutiva, de albergues noturnos policiados para os que não têm lar, o aumento dos hospitais para moléstias contagiosas, cuja propagação cumpre impedir como uma ameaça à higiene publica, as oficinas elementares para os cegos adultos, são outros tantos refúgios para os desgraçados que imploram a caridade publica por necessidade, que neles encontrarão a assistência, sucedânea de esmola, evitando as durezas da desigualdade no torvelinho social ${ }^{240}$.

Outro importante tema debatido na Conferência, agora mais diretamente ligado às organizações operárias, era o relativo ao direito de vigiar pessoas perigosas. No próximo capítulo, será exposta a ação policial no Recife contra essas organizações e ficará evidenciado que a polícia civil infiltrava seus agentes nos sindicatos, comícios e meetings e não envidava esforços para mapear todas as organizações. Ao mesmo tempo, vigiava os jornais de publicação anarquista ou operária, restringia a circulação de seus documentos, prendia

fossem dispensados castigos e tratamento imoderado e cruel. Refere-se a tese especificamente aos cocheiros e carroceiros.

${ }^{238}$ Constituia crime, nos termos do artigo 379 do Código Penal de 1890: “Art. 379. Usar de nome supposto, trocado ou mudado, de titulo, distinctivo, uniforme ou condecoração que não tenha"

${ }^{239}$ LEAL, Aurelino. Tese III. Seção III. Annaes da Conferência Judiciária-Policial de 1917. Vol. I. Rio de Janeiro: Imprensa Nacional, 1918.

${ }^{240}$ PITANGA, Antônio Ferreira de Souza. Tese IV. Seção III. Annaes da Conferência Judiciária-Policial de 1917. Vol. I. Rio de Janeiro: Imprensa Nacional, 1918, p. 423. 
trabalhadores para averiguá-los e determinava a expulsão dos estrangeiros envolvidos em atividades tidas como nocivas à ordem pública.

Todos esses atos eram determinados pelo chefe de policia ou pelos próprios delegados e subdelegados, à revelia de qualquer autorização judicial e em nome do poder de polícia. Não se sabe ao certo o quanto essas organizações operárias recorriam a ações judiciais para evitar essa constante vigilância ou mesmo para demandar reparações pela violação às garantias constitucionais à associação, à intimidade, à privacidade e à inviolabilidade de domicílio. Seria preciso desenvolver uma pesquisa especificamente na justiça para verificar se essas demandas existiam e, se sim, como eram julgadas. Mas fato é que a polícia estava cotidianamente na espreita desses movimentos.

Na Conferência, a temática veio à tona em mais de uma tese. Uma delas é a de Augusto Viveiros de Castro, o qual, não apenas como doutrinador, mas como ministro do STF, entendia não constituir constrangimento ilegal a vigilância que a polícia entende dever "exercer sobre certas pessoas consideradas suspeitas; ao contrário, é uma condição indispensável para que ela possa exercer convenientemente sua ação preventiva". Para ele,

Firmada a doutrina jurídica no sentido de ser a liberdade individual naturalmente limitada pelo interesse social e pela necessidade de ser mantida a ordem pública, me parece incontestável o direito da Polícia de impor essas limitações, sempre que as circunstâncias do momento exigirem o emprego de providencias dessa ordem ${ }^{241}$.

Os discursos de Castro são, junto aos dos representantes policiais na Conferência, os que mais se aproximam a um ideal de defesa social. Ele não titubeia em criticar o excesso de liberalismo de nossas legislações e a necessidade de se limitar esses direitos, sobretudo por uma razão de ordem coletiva. Sem dúvidas, ele representa um tipo de pensamento que dominará a produção legislativa no campo penal na década de 1930, no Estado Novo, quando a defesa do Estado e da segurança nacional parecia justificar toda e qualquer medida em termos de imputação criminosa.

O debate sobre a liberdade das organizações operárias apareceu também na tese IX da segunda seção, defendida por Galdino Siqueira. O jurista defendeu em seu trabalhado a liberdade de associação dos trabalhadores, bem como a legalidade da greve ${ }^{242}$. Para Siqueira, a maioria dos países avançados e civilizados admitia a "parede", desde que realizada sem

${ }^{241}$ CASTRO, Augusto Olympio Viveiros de. These VI. Seção II. Annaes da Conferência Judiciária-Policial de 1917. Vol. I. Rio de Janeiro: Imprensa Nacional, 1918, p. 256.

${ }^{242}$ SIQUEIRA, Galdino. Tese IX. Seção II. Annaes da Conferência Judiciária-Policial de 1917. Vol. 1. Rio de Janeiro: Imprensa Nacional, 1918. 
violência ou grave ameaça à pessoa e o Brasil teria andado bem quando descriminalizou a conduta nas hipóteses em que acontecia pacificamente. Sem dúvidas, Siqueira era bem mais liberal que Castro.

Porém, ao ser submetida a aprovação, um trecho importante de sua tese não foi aceito por Aurelino Leal. Galdino defendia que competia somente ao poder judiciário dissolver sindicatos; para o organizador da Conferência, isso era uma questão de polícia. Ao mesmo tempo, o relator da tese, Astolpho de Rezende, defendia a possibilidade de uso do habeas corpus como o instrumento legal cabível para titular a liberdade de associação - tese da qual o próprio Galdino discordava, por entender que o habeas corpus restringia-se às hipóteses de violação ao direito de locomoção ${ }^{243}$.

Aurelino Leal, ao longo dos debates, pediu a palavra para expor um pouco da sua experiência como Chefe de polícia no Distrito Federal na gestão dos problemas operários. Primeiramente, relatou o quanto algumas greves que acompanhou na cidade do Rio de Janeiro eram atos em si dotados de extrema violência e intimidação, porque os que aderiam ao movimento coagiam os demais trabalhadores a pararem suas atividades. Além disso, ao acompanhar as "paredes" a polícia acabava tendo proximidade com as duas partes envolvidas no conflito, podendo funcionar como uma instância de conciliação.

Siqueira pediu novamente a palavra para dizer que a greve somente poderia ser considerada ofensiva à ordem pública se, de fato, os que a ela aderissem agissem com violência direta contra pessoas. Ainda, aduzia que a polícia não poderia funcionar como juiz arbitral nas questões entre operários e patrões ${ }^{244}$.

Ao final, Aurelino saiu vencedor e todas as suas emendas foram aprovadas. Quanto ao uso de habeas corpus para impugnar a dissolução dos sindicatos, proposto por Adolpho Rezende, houve rejeição unânime.

Outro tema sensível no tocante às liberdades individuais era relativo à circulação de estrangeiros. Em mais de um dos debates ocorridos na Conferência, a presença de imigrantes foi percebida como ameaçadora e ligada à subversão. Viveiros de Castro expressou claramente que "Dissolução e anarquia trazem-nos hoje da Europa os estrangeiros

\footnotetext{
${ }^{243}$ ATA DA NONA REUNIÃO DA SEGUNDA SEÇÃO. Annaes da Conferência Judiciária-Policial de 1917. Vol. 2. Rio de Janeiro: Imprensa Nacional, 1918, p. 220-223.

${ }^{244}$ ATA DA NONA REUNIÃO DA SEGUNDA SEÇÃO. Annaes da Conferência Judiciária-Policial de 1917. Vol. 2. Rio de Janeiro: Imprensa Nacional, 1918, p. 231.
} 
insubmissos a toda lei divina e humana, os inimigos do Estado e da propriedade, da família, da pátria, da moral e do direito" ${ }^{, 245}$.

Sendo assim, apesar de a entrada desses indivíduos estar garantida em sede constitucional, debatia-se a possibilidade de expulsão por parte da autoridade policial de estrangeiros envolvidos em atos contrários à ordem pública, quase sempre associados às manifestações operárias.

A essa temática dedicou-se expressamente Rodrigo Octavio, na tese VII da segunda seção ${ }^{246}$. A tese dele é a de que estrangeiros poderiam ser expulsos ou não admitidos em território nacional se constituíssem um risco à ordem pública, tal qual apregoado pelo Decreto n. 1.641 de 1907, que, como destacado nos debates por Celso Vieira, "teve dois fins capitais: reagir politicamente contra o anarquismo, em defesa do Estado; reagir moralmente contra a delinquência apurada pelos Tribunais e em particular contra a vadiagem, a mendicidade e o lenocínio, em defesa da sociedade" ${ }^{247}$.

A liberdade de imprensa também foi abordada na Conferência, em tese exposta pelo próprio Aurelino Leal. Ele se opõe veementemente ao que chama de "desserviço da imprensa" no combate ao crime, ponderando que os jornais costumavam divulgar diretamente atividades ilícitas (como os números do jogo do bicho, anúncios de cartomantes e até de abortos), criticar injustamente o trabalho policial e mesmo fomentar atividades nocivas à ordem pública, como as revoltas operárias. Neste último caso, Leal destaca que a liberdade de imprensa garantida na Constituição não é absoluta e, portanto, estava assegurada à polícia a possibilidade de exercer censura sobre conteúdos indevidos e potencialmente perturbadores da ordem ${ }^{248}$.

Enfim, a leitura das teses produzidas ao longo daquele ano não deixa dúvidas de que a tendência menos liberal encampada por Aurelino Leal e Augusto Olympio Viveiros de Castro prevaleceu: a polícia e o judiciário precisavam estar em sintonia perfeita para um combate eficiente ao crime. Foram basicamente vitoriosas as posições e as propostas que esses dois ideólogos da Reação souberam defender e apresentar ${ }^{249}$.

\footnotetext{
${ }^{245}$ ATA DA OITAVA REUNIÃO DA SEGUNDA SEÇÃO. Annaes da Conferência Judiciária-Policial de 1917. Vol. 2. Rio de Janeiro: Imprensa Nacional, 1918, p. 204.

${ }^{246}$ OCTAVIO, Rodrigo. Tese VII. Seção II. Annaes da Conferência Judiciária-Policial de 1917. Vol. 1. Rio de Janeiro: Imprensa Nacional, 1918.

${ }^{247}$ ATA DA NONA REUNIÃO DA SEGUNDA SEÇÃO. Annaes da Conferência Judiciária-Policial de 1917. Vol. 2. Rio de Janeiro: Imprensa Nacional, 1918, p. 214.

${ }^{248}$ LEAL, Aurelino. These I. Seção III. Annaes da Conferência Judiciária-Policial de 1917. Vol. 1. Rio de Janeiro: Imprensa Nacional, 1918.

${ }^{249}$ TÓRTIMA, Pedro. Polícia e justiça de mãos dadas: A conferência Judiciário-Policial de 1917. Dissertação de Mestrado. Instituto de Ciências Humanas e Filosofia. Centro de Estudos Gerais. Universidade Federal Fluminense, 1988, p. 183.
} 
Ainda mais curioso é que os trabalhos da Conferência acabaram sendo interrompidos em decorrência das atividades da Greve Geral de 1917. No discurso com o qual encerrou o evento, Aurelino lembrou que a Conferência não poderia ter ocorrido em um momento mais oportuno. Afinal, aquela reunião entre policiais e juízes teria logrado êxito direto e imediato na repressão aos trabalhadores envolvidos naquelas greves:

O primeiro triunfo se concretizou no habeas corpus com que os anarquistas pretenderam garantir-se o direito de realizar 'comícios operários em qualquer praça, teatro ou outro lugar conveniente desta cidade'. Por unanimidade de votos, a $3^{\text {a }}$ Câmara da Côrte de Apelação adotou os motivos por mim expostos, no tocante a localização de meetings, reconhecendo tal direito à polícia. Batidos ai, os anarquistas recorreram ao Supremo Tribunal Federal, onde mais ruidosa decepção os feriu. Ao nosso eminente Confrade, o Ministro Viveiros de Castro, que redigira magistralmente na Conferência, a tese sobre liberdades individuais e suas restrições, coube a sorte de relatar o recurso. (...) Pode-se dizer que essa sentença de nossa suprema Corte foi a carta de lei conservadora da ordem pública da cidade ${ }^{250}$.

Os operários saíram derrotados. Aurelino, envaidecido. O primeiro grande esforço de reunir policiais e juízes parecia ter criado bases sólidas para a defesa social, mesmo a nível do STF, o que não era pouca coisa.

Não é possível saber, ao certo, o alcance dos debates realizados na Conferência no campo policial e jurídico brasileiro. As teses, entretanto, publicadas pela Imprensa Nacional, estariam à disposição de quem delas precisasse para justificar suas condutas. Era um importante documento de legitimação para uma polícia soberana.

No próximo capítulo, pretendo expor as práticas da polícia do Recife entre 1915 e 1930. As razões metodológicas desse recorte espacial e temporal já foram expostas no primeiro capítulo. Agora é o momento de verificar como uma polícia que acumulou práticas de mandatária nas ruas agia e frente a que população, majoritariamente, desempenhava seu poder soberano. Não é qualquer novidade o que será lido nas próximas páginas, porque ali serão vistos pobres e negros vivendo no encalço policial. Porém, algumas particularidades daquele cotidiano poderão abrir novas chaves interpretativas para o controle policial no Brasil.

${ }^{250}$ LEAL, Aurelino. Polícia e poder de polícia. Rio de Janeiro: Imprensa Nacional, 1918, p. 57. 


\section{OS MUCAMBOS E A RUA: UNIDADES ESPACIAIS DA SOBERANIA POLICIAL}

\subsection{OS ESPAÇOS DA DEGENERESCÊNCIA}

Constituem infelizmente um dos maiores defeitos desta cidade as habitações da população operária. Os mucambos e cortiços são uma ameaça constante á saúde pública

Era esse o teor de parte do ofício encaminhado, em 1908, pelo Secretário Geral de Pernambuco, Elpídio de Abreu e Lima Figueiredo, ao governador, Sigismundo Gonçalves ${ }^{251}$. A palavra mucambo aparece junto a cortiço, as típicas moradias populares brasileiras do final do XIX e início do XX. Como o próprio secretário descreve, trata-se de habitações operárias. Mucambo foi, também, ao longo do século XIX, um sinônimo de quilombo, a forma como, no estado da Bahia, eram preferencialmente denominadas essas comunidades ${ }^{252}$. Nas cidades, os mucambos eram o deslocamento, ao espaço urbano, das senzalas.

O ofício nos remete a uma importante reflexão sobre a construção da imagem do sujeito desviante no período estudado. Nos jornais, na literatura e na produção científica, corriqueiramente, a imagem do negro e do pobre - os moradores desses mucambos - é associada aos padrões de comportamento imorais e criminosos. Essa tendência se reproduz nos campos jurídico e policial.

Ilustrativa é, neste sentido, a obra do professor da Faculdade de Direito do Recife, Clovis Bevilaqua, "Criminologia e Direito", publicada em 1896. Ao longo do texto e das várias problemáticas tratadas, ele primeiramente adverte sobre os exageros das conclusões lombrosianas, por demais atreladas à constituição biológica do indivíduo: "No crime, como no direito, e mais visível naquele do que neste, há um aspecto puramente biológico: são as raízes, os fundamentos, as condições primárias. Mas esse bolbo não germinaria se não encontrasse o meio social" ${ }^{\prime 253}$. O meio social, o lugar onde as pessoas nascem e vivem, onde estabelecem seus laços familiares, de amizade e profissionais, ali sim, talvez, encontrássemos mais precisamente as respostas para os porquês da criminalidade.

Segundo Bevilaqua, o crime germinaria de atividades como os jogos de bicho, a prostituição, o alcoolismo, a desorganização familiar ${ }^{254}$ e também da falta de educação moral

\footnotetext{
251 MAIA, Clarissa Nunes. Policiados: controle e disciplina das classes populares na cidade do Recife, 1865 1915. Tese de doutorado. Programa de Pós-Graduação em História da UFPE, 2001, p. 70.

${ }^{252}$ GOMES, Flávio dos Santos. Mocambos e quilombos. São Paulo: Claro Enigma, 2015, p. 11.

${ }^{253}$ BEVILAQUA, Clóvis. Criminologia e direito. Salvador: Livraria Magalhães, 1896, p. 20.

${ }^{254}$ BEVILAQUA, Clóvis. Criminologia e direito. Salvador: Livraria Magalhães, 1896, p. 87.
} 
e doméstica, todos esses fatores predominantes nas duas raças inferiores - indígenas e negros, as quais

contribuem muito mais poderosamente para a criminalidade do que os arianos, creio que, principalmente, por defeito de educação e pelo impulso do alcoolismo, porquanto grande numero de crimes violentos têm sua origem nos sambas, si não são mesmo durante eles praticados ${ }^{255}$.

Desatrelando-se da explicação do delito dada meramente pelo determinismo biológico, a cor da pele e a constituição física do corpo negro cedem lugar a outros elementos que são igualmente racializados como o modo de vida, o bairro, os costumes e as manifestações culturais. Estas últimas explicações permearão o pensamento criminológico por muito tempo sem mencionar necessariamente o termo "raça", mas trazendo consigo essa mesma percepção.

Essas ideias não eram apenas comungadas entre criminólogos, juristas e policiais e faziam parte do senso comum. Em muitas ocasiões, encontrei cidadãos encaminhando reclamações à polícia contra o aumento da criminalidade e a presença de vagabundos e prostitutas nas ruas. No estudo já citado de Eduardo Silva, "As queixas do povo", o autor verificou que, em 1900, as indignações de cidadãos dirigidas ao jornal do Brasil contra capoeiras e desocupados e a imoralidade pública chegavam a $15,7 \%$ do total $^{256}$.

Os mucambos causavam, de fato, espécie. Nele, os desviantes de classe (proletariado), de raça (o negro) e de gênero (prostitutas e pederastas) coabitam e, sob muitos olhares, isso seria um risco. Ao descrever o mucambo como uma "ameaça constante à saúde pública", o Secretário Geral de Pernambuco evidencia o quanto as ideias biológicas de raças inferiores, a descoberta de doenças contagiosas e os discursos sobre o controle da sexualidade feminina e a reação à organização da classe operária estão amplamente imbricados e alimentavam também o imaginário do qual teriam se originado.

Anne McClintock, em "Couro Imperial”, faz uma interessante reflexão sobre essas complexas relações no discurso modernizante europeu e, em específico, vitoriano, na Inglaterra. No século XIX, os irlandeses eram frequentemente tratados como uma raça degenerada, embora fossem brancos, desafiando algumas teorias coloniais que identificavam na cor da pele o sinal da degenerescência.

Em 1860, na capa do jornal The Times, comenta a autora, uma matéria vai se referir aos irlandeses como "negros brancos". A expressão me lembrou outra que ouvia desde

\footnotetext{
${ }^{255}$ BEVILAQUA, Clóvis. Criminologia e direito. Salvador: Livraria Magalhães, 1896, p. 94.

${ }^{256}$ SILVA, Eduardo. As queixas do povo. Rio de Janeiro: Paz e Terra, 1988, p. 107.
} 
criança no Recife: "Fulano é negro de alma branca". Lá e aqui, o vício é atrelado à raça. Para McClintock, o homem branco inglês, naquele contexto, era o "pináculo da hierarquia da evolução" 257 e os estigmas da raça eram deslizados para outras relações de hierarquia como as de classe ou de gênero, fazendo, portanto, a classe trabalhadora se enegrecer ou as mulheres possuírem também elementos do atavismo negro, para serem definidas como inferiores aos homens.

Aproximando-se dessa reflexão, Hamlin e Ferreira destacam a proximidade das construções do ser negro e feminino, ambos dotados de atributos ambíguos que os aproximam do instintivo e da natureza, da não-razão: dóceis e desregrados e santos e sexualmente impulsivos. Nessa aparente contradição, a certeza sobre ambos esses corpos, pontuam os autores, é a de que não poderiam deixar de circular, posto que o discurso civilizatório precisa da imagem da barbárie para se afirmar ${ }^{258}$.

Foi visto como a polícia moderna era identificada a uma polícia embranquecida. Enegrecer era retroceder ao atavismo bárbaro e embranquecer era progredir à modernidade civilizada. Parece-me que é exatamente esse deslize que o mucambo vivencia. Seus moradores são todos pretos ou pobres e, estes últimos, enegrecidos pela degenerescência advinda da falta de educação e da tendência ao alcoolismo, como fala Bevilaqua, mais comum entre as raças inferiores.

Por outro lado, apesar de moradia, o mucambo não é uma casa, pois desafia a dicotomia clássica entre público versus privado ou casa versus rua. O mucambo é por vezes representado como uma moradia que reúne diversas pessoas que partilham de princípios de organização familiar diverso do modelo tradicional. Anos depois do envio do ofício acima referido, Gilberto Freyre, ao se referir a esses locais, falaria que a reunião dos mucambos eram como "comunidades suprafamiliares" ${ }^{259}$, onde negros e negras tentavam resgatar antigas formas de habitação africana, baseada na convivência entre diversos grupos.

Freyre ainda se reporta a estudos sobre essas moradias na cidade do Rio de Janeiro, no século XIX, onde o mucambo era frequentemente retratado como espaço da prostituta do tipo "escória" ${ }^{260}$. Falarei adiante sobre essa classificação.

Enfim, naquele espaço, negros, mulheres e operários, em certa medida, reunir-se-ão como classe degenerada, "vistas coletivamente através de imagens de patologia sexual e

\footnotetext{
${ }^{257}$ MCCLINTOCK, Anne. Couro Imperial: raça, gênero e sexualidade no embate colonial. Campinas: Editora Unicamp, 2010, p. 96.

258 FERREIRA, Jonatas; HAMLIN, Cynthia. Mulheres, negros e outros monstros. Estudos Feministas, Florianópolis, 18(3), p. 811-836, set/dez, 2010, p. 815.

${ }^{259}$ FREYRE, Gilberto. Sobrados e mucambos. São Paulo: Global, 2004, p. 413.

${ }^{260}$ FREYRE, Gilberto. Sobrados e mucambos. São Paulo: Global, 2004, p. 416.
} 
aberração racial”261, como, finalmente, ameaçadores e passíveis de vigilância. A criminologia, no período, será fruto desse imaginário e ao mesmo tempo constituidor dele.

Por certo, a criminologia não inventou o mucambo e tampouco a visão negativa sobre seus moradores. Quando ela surge, no Brasil, a escravidão se perpetuava há quase trezentos anos e, com ela, a certeza da inferioridade do ser negro e uma gestão das ilegalidades populares e negras atrelada à manutenção das hierarquias sociais. Porém, a criminologia positivista poderia ser uma importante arma de legitimação do tratamento desigual conferido pelo sistema punitivo àquela população, na medida em que confirmava cientificamente a desigualdade racial e moral entre os homens, a despeito das previsões jurídicas de igualdade, sedimentadas com a Lei Áurea e a posterior Proclamação da República. Para Alvarez, a

criminologia representou a emergência de um discurso o campo da lei, discurso este capaz de propor, a partir da articulação da lei e da norma, um tratamento jurídico-penal diferenciado para determinados setores da população e, consequentemente, num plano mais geral, de estabelecer critérios diferenciados de cidadania ${ }^{262}$.

Elpídio Figueiredo - assim como o governador a quem ele encaminhou o ofício formou-se, em 1886, na Faculdade de Direito do Recife, onde eram frequentes debates sobre o crime a partir dos estudos da criminologia positivista e grande a tentação a resolver o problema da criminalidade a partir de seus postulados. Não sei se Elpídio estava inteirado desse debate.

De uma maneira ou de outra, como um saber bastante cúmplice do senso comum, o secretário geral tinha a certeza do que atacar para sanear a cidade do Recife: a imundície dos mucambos. Porém, a podridão deles e suas prostitutas, ébrios, vagabundos e operários também assolavam as ruas do Recife, onde "indigentes perigosos", precisam de repressão e prevenção, pois "destituídos de senso moral", estão aptos "à prática de quaisquer ações danosas", como disse, em 1918, o Chefe de polícia pernambucano, Antônio Magalhães ${ }^{263}$.

As forças policiais serão fundamentais nessa tarefa saneadora. Os mucambos e as ruas se tornarão, assim, os espaços da experiência soberana da polícia. Neste capítulo, vou me dedicar a expor essas práticas policiais na cidade do Recife.

${ }^{261}$ MCCLINTOCK, Anne. Couro Imperial: raça, gênero e sexualidade no embate colonial. Campinas: Editora Unicamp, 2010, p. 77.

${ }^{262}$ ALVAREZ, Marcos César. Bachareis, criminologistas e juristas: saber jurídico e Nova Escola Penal no Brasil. São Paulo: IBCCRIM, 2003, p. 32-33.

${ }^{263}$ APEJE, Fundo SSP, Caixa 2. Relatório da Chefia de Polícia, 1918. 
As micronarrativas que o arquivo me ofereceu, lidas pela tradição teórica da criminologia crítica, reforçou algumas certezas sobre aspectos do sistema punitivo como a seletividade, a violência institucional e a corrupção das agências penais. Por outro lado, encheu-me de dúvidas e de dificuldades de interpretação, gerando em mim a certeza de que nenhum modelo teórico será, por si só, capaz de dar conta da complexidade que envolve a polícia e sua relação com a comunidade.

Tentada a pensar essas práticas como um caos incognoscível, busquei, ainda assim, construir uma interpretação para os dados. Tentei alinhavar contribuições teóricas sobre o controle penal às práticas policiais no período observado, desafiando a leitura de ambas mutuamente. Acredito que o resultado seja como um tecido em tricot de pontos bem abertos. As linhas se cruzam, formam nós e um todo, mas os espaços largos lembram a incompletude e a imprescindibilidade de ver além.

\subsection{AS PRIORIDADES POLICIAIS: AFINAL, COM O QUE A POLÍCIA SE OCUPAVA?}

Já disse que falar em polícia como uma realidade unívoca não faz muito sentido. Além de contarmos com mais de uma força policial, policiais localizam-se em níveis distintos de hierarquia, havendo aqueles que podem decidir uma agenda de atuação e aqueles que devem obediência a essa agenda. A definição das prioridades de policiamento e de segurança pública era responsabilidade do Chefe de polícia, figura central, portanto, na construção das estatísticas criminais, pois definia onde colocar policiais e que práticas e condutas reprimir.

Essas estatísticas, portanto, apresentam muitos vieses, a começar pelas cifras ocultas crimes não reportados à polícia. Mas não são apenas elas. Como será visto, os "índices de criminalidade" são muitas vezes fruto de campanhas empreendidas pela Chefia de Polícia, às vezes tendente a reprimir o jogo ilegal, às vezes mais focada na prostituição, outras vezes menos preocupada com essas condutas. Sendo assim, não lerei esses números como a realidade criminal do Recife, mas sim como representações das escolhas policiais.

Os dados foram extraídos dos documentos do Gabinete de Identificação e Investigação da Chefatura de Polícia de Pernambuco, os quais eram compilados anualmente e divulgados no Relatório do Chefe de polícia.

Não encontrei os relatórios de todos os anos pesquisados, mas cobri um período que vai de 1912 a 1927, com relatórios referentes aos anos de 1912, 1914, 1918, 1922 e 1927, permitindo uma comparação, ao longo de quinze anos, de prioridades e da atuação policial.

Nos relatórios, há o quantitativo e o perfil socioeconômico das pessoas encaminhadas à Casa de Detenção do Recife por prática de crimes e de contravenções, a quantidade de 
pessoas registradas civilmente, a frequência de exames médico-legais realizados, o número de crimes praticados em todo o estado pelo tipo penal e pelo município, a frequência de suicídios e acidentes e os números da assistência policial, que lidava com menores e loucos. Porém, a produção dos relatórios não é padronizada e nem todos possuem exatamente as mesmas informações. Por isso, às vezes apresentarei dados relativos a apenas alguns dos anos e, noutros momentos, conseguirei apresentar uma série histórica maior, permitindo compreender rupturas e continuidades.

É válido destacar que, nesses documentos, além dos dados estatísticos, o Chefe de polícia faz um apanhado da questão criminal como um todo, tratando de questões críticas, a exemplo, em 1917, dos movimentos grevistas, em 1918, de conflitos entre brasileiros e alemães, em decorrência da postura da Alemanha na I Guerra Mundial e, em 1927, do banditismo e do cangaço, dentre outras pautas prementes. Por fim, apontam para dificuldades do policiamento, sugerindo mudanças na formação dos policiais e em suas carreiras, construção de delegacias de polícia, modificação de atribuições, redistribuição de efetivo, dentre outras. A linguagem e conteúdo dos relatórios são muito parecidas com a do Boletim Policial, sugerindo que essas revistas alcançam autoridades de outros estados brasileiros.

Ao manusear esses documentos, o primeiro dado que salta aos olhos é a prevalência de atuações policiais em relação às contravenções em comparação com os crimes. Nos capítulos anteriores, comentei que as contravenções representavam o caminho jurídico-penal para a interferência policial sobre as chamadas classes perigosas e que, no Distrito Federal, a polícia civil, junto a políticos locais, procurava caminhos para punir melhor essas condutas. Prostitutas, ébrios, vagabundos, mendigos, capoeiras, caftens, jogadores, operários subversivos, todos eles, em certa medida, teriam facilmente suas ações cerceadas pela força policial com base em algum dos artigos do Livro III do Código Penal de 1890.

A variação quantitativa de detenções na Casa de Detenção do Recife por crime e por contravenção foi a seguinte:

Gráfico 1: Entradas - CDR (crimes e contravenções) - 1912, 1914, 1922 e $1927^{264}$

${ }^{264}$ Fonte: Relatórios anuais das Chefias de Polícia. Anos: 1912, 1914, 1918 e 1927. 


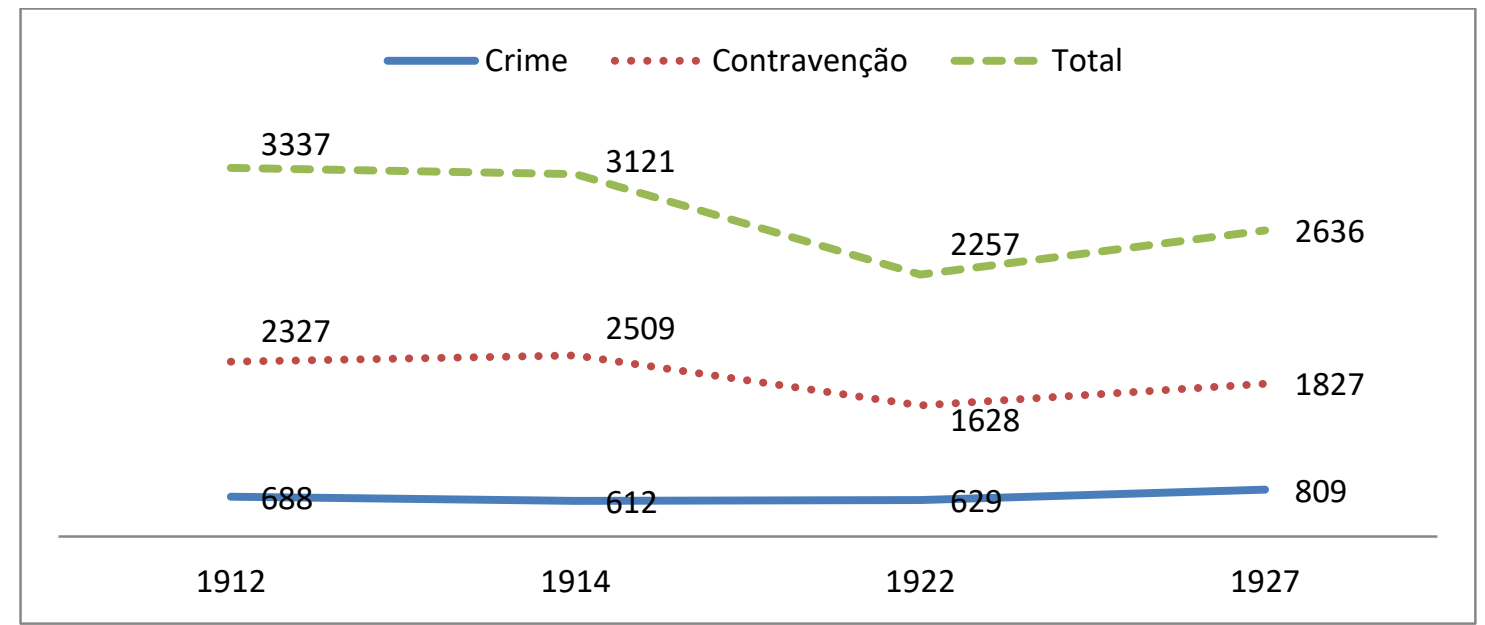

Em todos os anos, as apreensões por contravenção correspondem a mais do que o dobro das realizadas por crimes, embora entre 1912 e 1927, haja uma visível redução no número de entradas na CDR pela prática de contravenções e um pequeno aumento no número de prisões que tiveram como causa a imputação de um crime. Se pensarmos que, de 1912 a 1927, a população da cidade do Recife mais do que dobrou, poderíamos concluir que houve uma redução considerável das taxas de encarceramento no período.

Segundo informações do IBGE, em 1910, a população do Recife era de 193.429 habitantes e em 1920, de 238.843. No Relatório da Chefia de Polícia de 1928, fala-se em uma cidade com "cerca de 300.000 habitantes". Com base nas informações oficiais sobre a população da cidade, podem-se calcular, aproximativamente, as taxas de encarceramento:

Gráfico 2: Taxas de encarceramento por 100.000 habitantes na cidade do Recife - 1912, 1914, 1922, $1927^{265}$

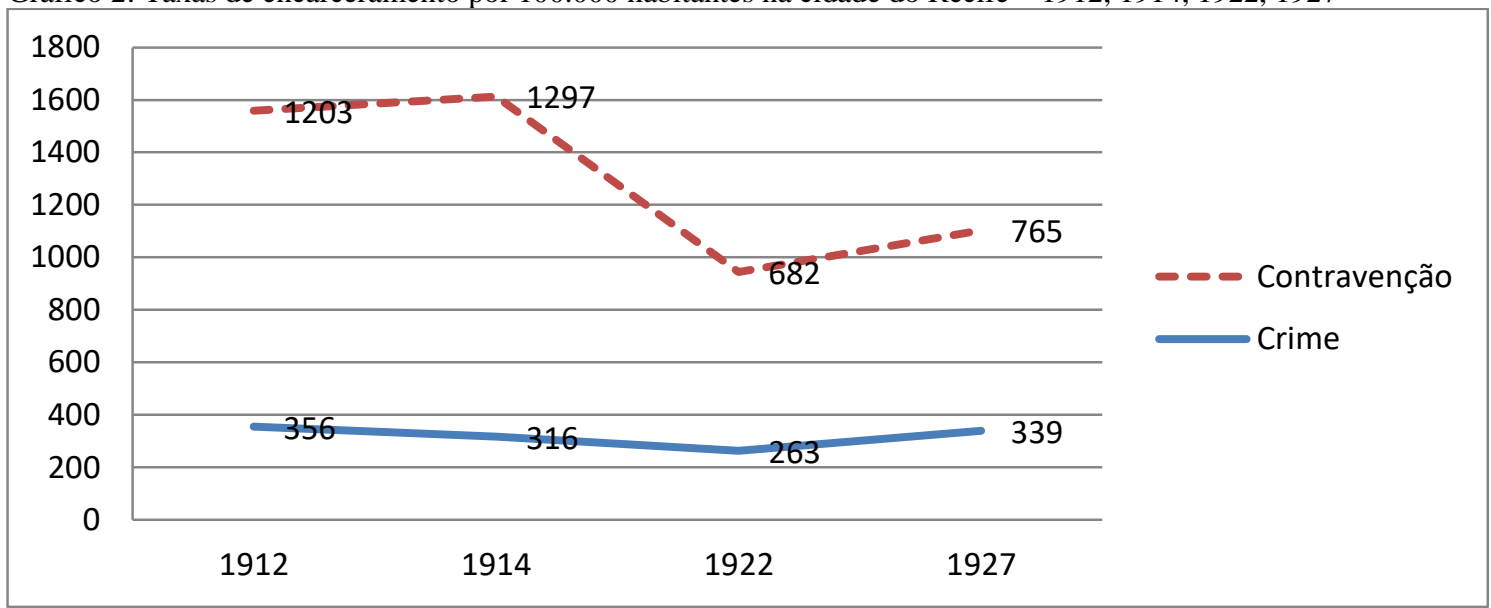

${ }^{265}$ Fontes: IBGE, Censo Demográfico 1920; IBGE, Estatísticas do Século XX. População das capitais do Estado do Brasil (1872, 1890, 1900, 1910). Relatórios anuais da Chefia de Polícia. * As taxas de 1912 e 1914 foram calculadas com base na população do Recife em 1910 e as taxas de 1922 e 1927, com base na população do Recife em 1920. 
De fato, houve uma baixa nas taxas de encarceramento por crime e por contravenção. Todavia, é preciso notar que, em todo o período, o encarceramento por contravenções alcançou níveis muito superiores ao que se tem hoje. Em 2016, a taxa de encarceramento no Brasil era de 306,2 presos por 100.000 habitantes, algo próximo às taxas de encarceramento por crime no período mencionado, mas muito menor que aquelas observadas nos casos de contravenção.

Em certa medida, prendíamos três vezes mais por contravenção do que hoje em relação aos crimes. Mais do que isso, as taxas acima foram calculadas somente com base nas entradas na Casa de Detenção do Recife, que correspondia a uma das unidades para onde eram encaminhados esses contraventores. Se considerarmos que mendigos e vagabundos tinham, além da CDR, outros destinos, como as carceragens nas delegacias, o Asylo de Mendicidade $^{266}$, a Escola Correcional ${ }^{267}$ e o Dispensário dos Pobres ${ }^{268}$, além da possibilidade de serem enviados ao Hospital Psiquiátrico como loucos e loucas, corre-se o risco de aumentar, em muito, essas taxas.

Para se ter uma ideia, no relatório da Chefia de Polícia de 1928, com dados de 1927, existe a informação de que foram detidos, no Recife, 566 mendigos e desocupados, os quais tiveram destinos diversos, sendo apenas 100 deles encaminhados à Casa de Detenção. Ainda, no mesmo relatório, são informadas a totalidade de detenções realizadas pelas cinco delegacias distritais da cidade do Recife, e somente elas foram responsáveis por 3.170 prisões, 813 por desordens e 596 por embriaguez, por exemplo. Esses dados são muito superiores às entradas na CDR. Em 1922, a situação é semelhante: são 2.257 entradas na CDR, mas 3.569 detenções efetuadas pela polícia apenas no Recife. É uma média de nove pessoas detidas diariamente!

Um quadro semelhante a este foi observado por Boris Fausto, estudando a cidade de São Paulo também no final do século XIX e início do XX. Ele verifica que, nos períodos de 1892 a 1896, 77\% das prisões decorriam de acusações de contravenções, ao passo que, de

\footnotetext{
${ }^{266}$ Criado, no Recife, em 1859, em meio a discussões médicas e higienistas sobre a cidade e os riscos da mendicidade. Engajaram-se na criação do Asylo de Mendicidade a Comissão de Higiene Pública (lei provincial $n^{0}$ 316), a Associação Comercial Beneficente e o poder público. Ver: MORAIS, Grasiela Florêncio de; ROSAS, Suzana C.. "Livrando-se o público dos mendigos": o controle sobre os mendigos e o processo de criação do asilo de mendicidade do Recife no século XIX (1840 a 1870). ANAIS DO II SEMINÁRIO INTERNACIONAL DA SEO. Niterói: Sociedade de Estudos do Oitocentos, 2017, v. 2. p. 1-8.

${ }^{267}$ Existiu, no Recife, de 1909 a 1929, dentro das dependências da Casa de Detenção do Recife.

${ }^{268}$ Entidade administrada pela Companhia de Caridade, ligada à Igreja Católica e mantida com doações.
} 
1912 a 1916, esse percentual foi de 85,6\%, demonstrando a preocupação crescente da polícia mantinha com a manutenção da ordem pública ${ }^{269}$.

No Maranhão, José Barros Filho apontou também para a prevalência das prisões correcionais em decorrência de contravenções, realizadas pela polícia e mantidas ou revogadas por ordem de delegados ou subdelegados, a despeito da falta de previsão constitucional e legal dessa atribuição ${ }^{270}$.

Enfim, as contravenções movimentavam bastante as forças policiais. Afinal, que tipos contravencionais geravam essas prisões? A tabela abaixo, com dados de 1914 e 1927, poderá nos ajudar a compreender.

Tabela 6: Entradas - CDR - Prisões contravencionais por sexo - 1914 e $1927^{271}$

\begin{tabular}{lcccccc}
\hline & \multicolumn{3}{c}{1914} & \multicolumn{3}{c}{1927} \\
\hline Desordens & Total & Homens & Mulheres & Total & Homens & Mulheres \\
Gatunagem & 835 & 712 & 123 & 411 & 390 & 21 \\
Vagabundos & 952 & 925 & 27 & 488 & 469 & 19 \\
Embriaguez & 32 & 30 & 2 & 337 & 254 & 83 \\
Ofensa à moral & 94 & 64 & 30 & 170 & 154 & 16 \\
Averiguações policiais & 127 & 50 & 77 & 85 & 32 & 53 \\
Catimbó & 0 & 0 & 0 & 60 & 58 & 2 \\
Loucos & 7 & 1 & 6 & 13 & 7 & 6 \\
Jogadores & 414 & 229 & 185 & 0 & 0 & 0 \\
Outros & 28 & 28 & 0 & 81 & 69 & 12 \\
Total & 20 & 19 & 1 & 195 & 182 & 13 \\
\hline
\end{tabular}

Antes de qualquer observação, é preciso atentar para a ausência de respeito à legalidade no registro e na realização dessas prisões. Os tipos contravencionais da polícia não correspondem aos do Código Penal, havendo uma caracterização da conduta baseada na linguagem da instituição, no "cop knowledge”, sem qualquer rigor técnico. Provavelmente não havia uma prestação de contas sistemática à justiça dessas detenções, porque, do contrário, seria possível questionar o tipo penal para prender alguém como desordeiro ou como catimbozeiro, por exemplo.

A ofensa à legalidade é uma das características marcantes da soberania policial e também foi um padrão observado por Luiz Antônio de Souza na polícia de São Paulo, para

\footnotetext{
${ }^{269}$ FAUSTO, Boris. Crime e cotidiano: a criminalidade em São Paulo (1880-1924). 2 ed. São Paulo: EDUSP, 2001, p. 45.

${ }^{270}$ BARROS FILHO, José. Criminologia e modos de controle social. No Maranhão no início do século XX. São Luís: FAPEMA, 2013, p. 137.

${ }^{271}$ Fonte: APEJE, Relatórios Chefe de Polícia, 1914 e 1928. Livros
} 
quem "no começo da Primeira República, parece que a polícia pretendia usar as prisões como uma forma de caracterização dos criminosos, e não dos crimes" ${ }^{272}$. Também no Recife, ao longo de toda a primeira República, são frequentes referências às prisões de gatunos, vigaristas, pederastas e tantas outras "figuras desviantes" sem correspondência na legislação penal.

A polícia, portanto, não lidava com condutas, mas com sujeitos. A preocupação era com os vagabundos e desordeiros da cidade, aqueles sujeitos cuja imagem era a representação do perigo, o que o penalismo crítico denominou de "direito penal do autor".

Outra observação preliminar é que loucura não era crime e nem contravenção, mas, no período, cabia à assistência policial deter alienados vagando pelas ruas. Em geral, eles eram recolhidos à Casa de Detenção e, após atestada a loucura, encaminhados ao Hospital de Alienados. Desse modo, o fato de no ano de 1927 não aparecerem prisões por loucura não implica que elas não tenham ocorrido, mas que, passaram a ser contabilizadas como números da assistência policial, separada dos dados criminais, o que não ocorreu em 1914.

Feitas essas considerações iniciais, passo aos números da tabela. Desordeiros e gatunos representam, juntos, $71 \%$ das apreensões. São essas figuras que vão, frequentemente, preencher os relatórios dos chefes de polícia, conforme verei adiante. A ofensa à moral, única das condutas que prende mais mulheres do que homens, era a forma como prostitutas poderiam ser policiadas, uma vez que prostituição, em si, não constituía um delito. Também há de se observar o grande número de prisões por embriaguez e jogos ilegais, que, aliás, intensificaram-se no final da década de 1920 e foi objeto de preocupação em praticamente todos os relatórios da Chefia de Polícia naquela década.

Outro dado relevante da tabela diz respeito às prisões por catimbó, que chegou ao número de 13 em 1927. Por vezes, ouvi esse termo sendo usado em tom pejorativo, na expressão "véia catimbozeira", que se referia a mulheres ruins. Acredito que seja esse também o tom do registro policial.

As religiões de matriz africana sofreram dura repressão ao longo da primeira república. O Código Penal de 1890, por exemplo, dispunha que era crime: “Art. 157: Praticar o espiritismo, a magia e seus sortilegios, usar de talismans e cartomancias para despertar sentimentos de odio ou amor, inculcar cura de molestias curaveis ou incuraveis, emfim, para

${ }^{272}$ SOUZA, Luiz Antonio Francisco de. Polícia, poder de polícia e criminalidade numa perspectiva histórica. KOERNER, Andrei (org.). História da justiça penal no Brasil: pesquisas e análises. São Paulo: IBCCRIM, 2006, p. 69. 
fascinar e subjugar a credulidade publica". Na doutrina, porém, havia uma distinção clara entre espiritismo de branco e espiritismo de negro.

Oscar de Macedo Soares, nos comentários a esse delito, ressalta que a simples prática do espiritismo não "constitui crime, [porque] é uma manifestação da liberdade de consciência""273, mas depois conclui, citando Aurelino Leal ${ }^{274}$, que "a mandinga é uma superstição que assume muitas formas e, não há dúvida, pode exercer influência decisiva sobre a gênese da criminalidade" ${ }^{275}$. O marcador racial mais uma vez fica evidente na definição do espiritismo constitucionalmente assegurado e aquele perigoso, a ser tratado como caso de polícia.

No Recife, apesar dessas prisões aparecerem nos números policiais, vi apenas um registro no livro de ofícios de delegados e subdelegados, em 1916. Tratou-se de uma prisão, no dia 30 de março daquele ano, de um - segundo o ofício do subdelegado - "catimbozeiro", no bairro da Encruzilhada. Com ele foram apreendidas garrafas de vinho, flores e castiçais. $\mathrm{O}$ preso se chamava João de Oliveira, conhecido também como João de Alencar ${ }^{276}$. Nada mais foi dito e eu não sei o que ocorreu a João de Oliveira ou o terreiro em que ele estava.

Já no livro de entradas da CDR de 1920, verifiquei a prisão de quatro pessoas por catimbó e desordem: Olympia Maria da Silva, 20 anos, parda, solteira e doméstica, José Cypriano, 30 anos, pardo, solteiro e carroceiro, José Amaro dos Santos, 20 anos, casado, pardo e jornaleiro e José Justino da Silva, 26 anos, preto, solteiro e jornaleiro. Todos foram presos no bairro de Santo Antônio no dia 20 de outubro de 1920 e liberados no dia seguinte, por ordem do subdelegado daquele bairro ${ }^{277}$. Não há processo, não há mais informações.

Porém, o fato de terem sido presos por catimbó e "desordens", figura esta inexistente no código penal e de enorme abertura semântica, sugere que outros 'catimbozeiros' fossem enquadrados como desordeiros, somando-se às centenas deles que eram presos e soltos quase que diariamente por delegados e subdelegados de polícia.

Por fim, a partir da década de 1920, um novo motivo para as prisões começam a ser contabilizados nos relatórios policiais: são as chamadas "prisões para averiguações". Não quer dizer que elas não ocorressem antes, mas, foi em 1921 que as vi pela primeira vez sendo

\footnotetext{
273 SOARES, Oscar Macedo. [1910] Código Penal da Republica dos Estados Unidos do Brasil commentado. Brasília: Senado Federal, Superior Tribunal de Justiça, Coleção História do Direito, vol. 6, 2004, p. 316.

${ }_{274}$ Aurelino Leal publicou, em 1898, um livro intitulado "A religião entre os condenados na Bahia".

275 SOARES, Oscar Macedo. [1910] Código Penal da Republica dos Estados Unidos do Brasil commentado. Brasília: Senado Federal, Superior Tribunal de Justiça, Coleção História do Direito, vol. 6, 2004, p. 318.

${ }^{276}$ APEJE, Fundo SSP, livro 457, Livro de Ofícios de Delegados e Subdelegados da $1^{\text {a }}$ Delegacia de Polícia, 1916.

${ }^{277}$ APEJE, Fundo SSP, Casa de Detenção do Recife. Livro de entradas e saídas. 1920.
} 
registradas, aparecendo, inclusive, como "prisão correcional”, apesar de não constituir um tipo penal ou contravencional.

A figura da prisão para averiguação não existia no Código de Processo Criminal e é comumente atribuída a períodos ditatoriais e autoritários. Nesses momentos políticos críticos, elas se tornam uma importante arma de controle de opositores e outros indivíduos que representam risco à manutenção do poder. Porém, no Recife da década de 1920, apesar de momentos de instabilidade política, havia uma democracia e polícia realizava prisões para averiguação com as mais diversas finalidades: mapear movimentos operários, fuçar a vida de prostitutas, identificar locais onde se realizavam jogos de azar, dentre outras. Somente no ano de 1927, 317 pessoas foram presas a fim de serem averiguadas. Poucos ofícios a esse respeito eram encaminhados à Chefia de Polícia e o conteúdo da averiguação aparece raramente nos registros policiais.

No que diz respeito aos crimes que movimentavam forças policiais, há uma grande prevalência das lesões corporais, seguida do homicídio. Juntos, esses dois crimes chegam a mais de 60\% das prisões em 1912, 47\% em 1921 e 50\% em $1927^{278}$. Há, ainda, um razoável número de prisões por furto (o percentual varia muito ano a ano, registrando, por exemplo, $5 \%$ nas prisões de 1918 e 32\% nas de 1921), roubo (cerca de 5\%) e defloramento (representando em torno de $5 \%$ das prisões).

Importante lembrar que o furto é muitas vezes reportado à autoridade policial por uma vítima e, em algumas vezes, instaura-se inquérito. Nos livros de ofícios de delegados e subdelegados, vi muitos casos de furto de joias, dinheiro em estabelecimentos comerciais, objetos os mais diversos dentro de navios etc. Inclusive, a depender da qualidade da vítima, esses furtos moviam investigações bastante robustas. Foi o caso do "Roubo da Joalharia Salathiel", em 1918, que, cuidou, de fato, de um furto daquele estabelecimento de dinheiro e joias, totalizando um valor de 300:000\$000. A loja pertencia a Salathiel de Albuquerque e o chefe de polícia, à época, empenhou-se diretamente nas investigações e designou o subdelegado de Santo Antonio, José Primo de Oliveira, exclusivamente para o caso que, entretanto, não foi elucidado ${ }^{279}$.

Noutras ocasiões, os pequenos furtos são tratados como gatunagem, figura inexistente no Código Penal, mas responsável por uma boa parte dos recolhimentos por "contravenção",

\footnotetext{
${ }^{278}$ Especificamente nesse ano, o Relatório da Chefia de Polícia dedica algumas páginas a comentar a redução do número de homicídios, graças à atividade policial de repressão e prevenção. Um gráfico é apresentado (anexo 8), demonstrando a queda vertiginosa no número de homicídios no Recife entre 1921 e 1927.

${ }^{279}$ APEJE, Fundo SSP, livro 459. Livro de Ofícios de Delegados e Subdelegados da $1^{a}$ Delegacia de Polícia. 1918.
} 
conforme visto acima. $\mathrm{O}$ gatuno era o indivíduo que praticava pequenos furtos, adaptando-se, portanto, mais à figura do contraventor, do vadio que permeia as ruas gerando insegurança.

Relativamente ao defloramento, também uma ponderação merece ser feita: considerando que muitos casos eram resolvidos nas Delegacias com o casamento da mulher com o deflorador, o número de prisões é, possivelmente, muito inferior ao de casos efetivamente reportados. Tratava-se de um dos espaços da atuação informal da justiça, como ressaltado no capítulo segundo deste trabalho.

Na tabela abaixo, há um comparativo do quantitativo de entradas, na CDR, por crime. O homicídio e as lesões corporais integram o capítulo dos "crimes contra a segurança da pessoa e vida", o defloramento, o dos crimes contra a "segurança da honra e honestidade das famílias" o furto, o dos "crimes contra a propriedade pública e particular" e o roubo, o dos "crimes contra a pessoa e a propriedade".

Tabela 7: Entrada - CDR - Crimes 1912,1914,1917 e $1918^{280}$

\begin{tabular}{lcccc}
\hline & 1912 & 1914 & 1917 & 1918 \\
\hline Dos crimes contra a segurança interna da Republica & 13 & 23 & 7 & 12 \\
Dos crimes contra a fé publica & 13 & 9 & 11 & 14 \\
Dos crimes contra a segurança da honra e honestidade & 87 & 62 & 76 & 42 \\
das familias e do ultraje publico ao pudor & 847 & 777 & 825 & 677 \\
Dos crimes contra a segurança de pessoa e vida & 99 & 40 & 114 & 52 \\
Dos crimes contra a propriedade publica e particular & 42 & 52 & 57 & 41 \\
Dos crimes contra a pessoa e a propriedade & 46 & 18 & 28 & 20 \\
Outros & 1147 & 981 & 1118 & 858 \\
Total & & &
\end{tabular}

Muitas dessas lesões corporais ocorriam, conforme informações constantes nos livros de ofícios de delegados e subdelegados de 1915 a 1930, em contextos de brigas por motivações muito diversas, como disputas comerciais, jogos, confusões em cafés e casas de prostituição.

Os homicídios, por sua vez, eram, por vezes, o desfecho trágico dessas brigas, merecendo destaque ainda aqueles praticados contra mulheres, que tinham como algozes quase sempre companheiros, ex-companheiros e maridos. Foi o caso de José Ramos de Oliveira que, no dia 7 de outubro de 1916, tentou matar a mulher Maria José Simplício, fato ocorrido no bairro de Santo Antonio e cujas diligências o delegado informava ter encaminhado ao juiz da $1^{\text {a }} \operatorname{Vara}^{281}$.

\footnotetext{
${ }^{280}$ Fonte: Relatórios anuais da Chefia de Polícia. Anos: 1912, 1914, 1918.

${ }^{281}$ APEJE, Fundo SSP, livro 457, Livro de Ofícios de Delegados e Subdelegados da $1^{\text {a }}$ Delegacia de Polícia, 1916.
} 
Para a compreensão aprofundada desses casos, é necessário um estudo sistemático desses crimes e o desfecho que tiveram na justiça, o que não constitui o objeto deste trabalho.

Aqui, procurei evidenciar e entender os elementos da soberania policial, os casos que jamais chegavam à justiça e eram resolvidos ao arbítrio de delegados, subdelegados ou, mesmo, de guardas civis, praças e soldados. Por essa razão, são as contravenções e a forma como a polícia lidava com elas que me interessam.

Atentar para esses casos de prisões por contravenção pode nos oferecer importantes pistas na compreensão do sistema punitivo brasileiro. Primeiramente porque tais contraventores passavam pouquíssimo tempo recolhidos - cerca de 5 a 10 dias no máximo impedindo, assim, que vivenciassem qualquer intervenção relevante em suas subjetividades, como a imposição de valores do trabalho, da família tradicional, de docilização etc, pressupostos caros a algumas teorias que procuram explicar o fenômeno da prisão, conforme verificarei no próximo capítulo.

Em segundo lugar, os casos em questão raramente iam parar na justiça, resolvendo-se no âmbito policial, com penas aplicadas sem processo e ao arbítrio da autoridade policial. Para se ter uma ideia, em 1917, foram remetidas à justiça, pelas delegacias policiais do Recife, 317 diligências ou inquéritos; em 1918, 148 inquéritos e em 1922, 247 inquéritos. Esses números não representam nem $10 \%$ das prisões efetuadas pelas polícia. Que infrações eram investigadas nesses procedimentos? Não obtive a informação em relação a todos os anos, mas, em 1922, dos 247 inquéritos enviados à justiça, 120 tratavam de ferimentos leves, 5 de ferimentos graves, 35 de homicídio, 20 de furto, 10 de roubo, 16 de defloramento e os demais por crimes como atropelamento, estelionato, rapto, incêndio e outros. Assim, de fato, quase nenhuma das milhares de prisões por contravenções chegava ao conhecimento do poder judiciário, havendo, também uma parcela considerável de crimes que jamais "subiriam" à instância judicial.

Essa conclusão também foi apontada por Luiz Antônio Francisco de Souza, que pesquisou inquéritos e práticas das delegacias de São Paulo entre os anos de 1889 e 1930. No movimento daquelas unidades, o autor verificou que a maior parte do trabalho policial não chegava à justiça, nem por meio de notificação, nem por meio de inquéritos. Em números muito semelhantes aos que eu observei no Recife, ele assevera que, em apenas um ano (1899), teria havido, em São Paulo, 6.324 prisões, sendo um quarto por crimes e as demais por contravenções. De todas essas prisões, pouquíssimos casos seriam tratados na esfera judicial, 
sugerindo uma polícia que funcionava verdadeiramente como uma justiça de primeira instância ${ }^{282}$.

Bretas, ao avaliar o caso do Rio de Janeiro, chegou a resultados semelhantes. A polícia raramente recorria aos procedimentos criminais quando o assunto era manter a ordem na cidade.

a seção encarregada de reprimir a vadiagem informou que, em 1928, efetuou 472 prisões que resultaram em apenas 61 processos. Uma noite na cadeia ou em alguns casos o assédio sistemático através de prisões contínuas funcionavam como um poderoso freio, sem haver necessidade de instaurar processos e envolver juízes quase sempre inclinados a absolver acusados em processos de vadiagem ${ }^{283}$.

Pairava no ar uma percepção, ainda partilhada hoje, de que "os pequenos crimes e consequentemente as pequenas penas não demandam tantas garantias, nem um processo cheio de formas e morosidades que consumiria mais tempo e despesas do que a importância do assunto exigia" ${ }^{284}$, como comenta J. A. Pimenta Bueno. Embora, sem dúvidas, a máquina da burocracia judicial parecesse lenta e morosa para resolver conflitos aparentemente de pequeno porte, a jurisdição policial não servia propriamente a isso, como se vê, mas à administração da circulação nas cidades dos indivíduos considerados perigosos, a quem não se reservava "tantas garantias", mas nenhuma.

Em terceiro lugar, olhar para essas contravenções é questionar alguns lugares comuns com os quais lidamos em relação à criminalização das mulheres. Normalmente, as baixas taxas de encarceramento feminino, que não chegam a ultrapassar 5\% em praticamente todos os períodos do século $\mathrm{XX}$, conduzem os estudos no campo criminal a afirmarem que sobre as mulheres recai, preferencialmente, um tipo de controle informal, exercido por instâncias como a família, a religião, a escola integral, os quais, falhando, conduzem ao encaminhamento delas às instâncias penais oficiais.

Na tabela abaixo, relativa ao ano de 1914, verifica-se o percentual de prisões de mulheres por prática de crimes é de 3,5\%. Porém, quando se olha para as contravenções, essas

${ }^{282}$ SOUZA, Luiz Antonio Francisco de. Polícia, poder de polícia e criminalidade numa perspectiva histórica. KOERNER, Andrei (org.). História da justiça penal no Brasil: pesquisas e análises. São Paulo: IBCCRIM, 2006, p. 69.

${ }^{283}$ BRETAS, Marcos Luiz. Ordem na cidade: o exercício cotidiano da autoridade policial no Rio de Janeiro: 1907-1930. Rio de Janeiro: Rocco, 1997, p. 82.

${ }^{284}$ BUENO, Antonio José Pimenta. Apontamentos sobre o processo criminal brazileiro. 2 ed. Rio de Janeiro: Guarnier, 1857. 
mulheres têm uma participação muito mais expressiva, chegando a corresponder a $18 \%$ do total de recolhimentos.

Tabela 8: Entradas por crime e contravenção por sexo - CDR - $1914^{285}$

\begin{tabular}{lcccc}
\hline & \multicolumn{2}{c}{ Crime } & \multicolumn{2}{c}{ Contravenção } \\
\hline \multirow{3}{*}{ Homens } & Total & Percentual & Total & Percentual \\
Mulheres & 591 & 96,5 & 2058 & 82 \\
Total & 21 & 3,5 & 451 & 18 \\
\hline
\end{tabular}

Comparando o número absoluto de prisões por contravenção nos anos pesquisados e por sexo, verifica-se, inclusive, que a redução maior dessas prisões se dá em relação aos homens, mantendo-se um número mais ou menos constante de prisões de mulheres por contravenções.

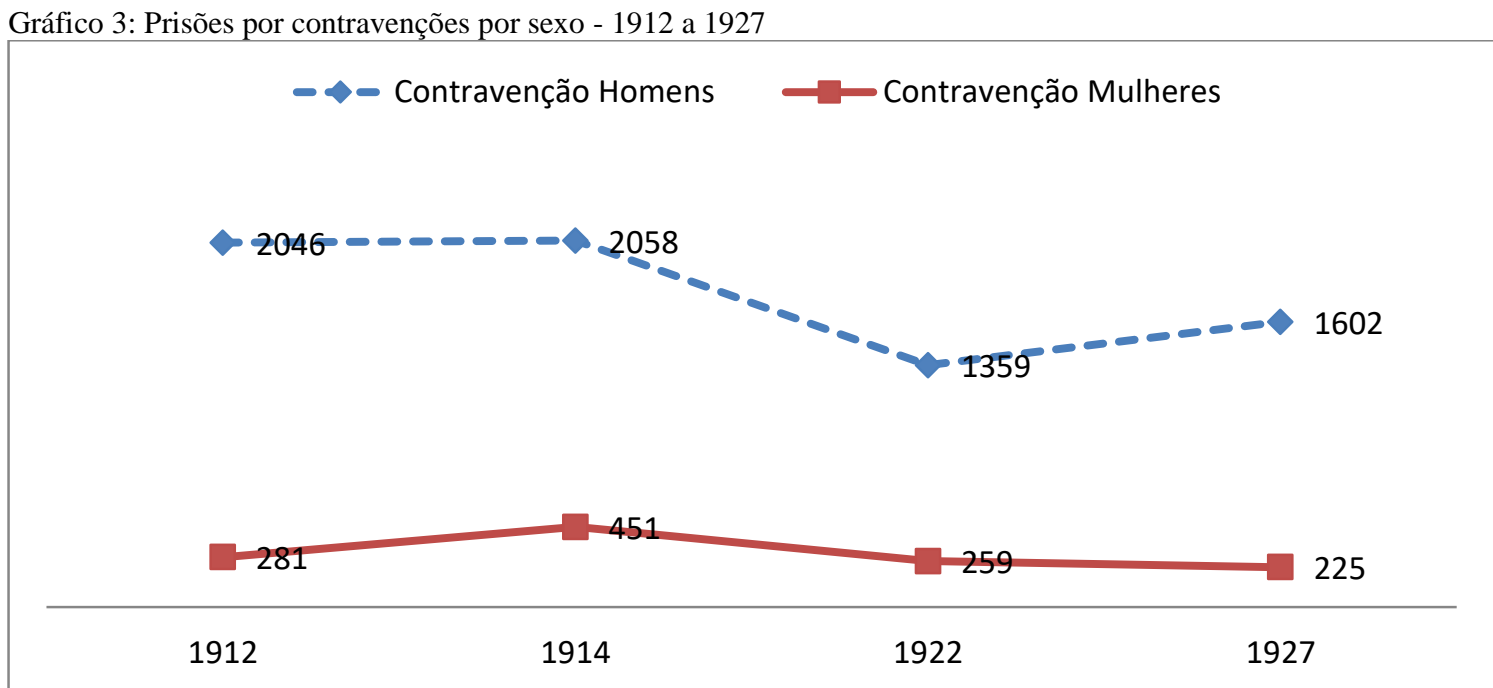

Quem eram essas mulheres vivendo sob o cerco policial? Adiante buscarei chegar um pouco mais perto de cada uma delas e retomar as discussões aventadas.

Por fim, no Recife, tanto os crimes como as contravenções eram, preferencialmente, um problema de pessoas negras. As informações sobre a cor dos presos não consta em todos os relatórios e está sistematizada apenas no de 1912.

${ }^{285}$ Fonte: APEJE, Fundo Secretaria Geral, Livro 190, Relatório da Chefia de Polícia, 1914. 
Tabela 9: Entradas - CDR- 1912 por cor do preso $^{286}$

\begin{tabular}{lcccc}
\hline & \multicolumn{2}{c}{ Contravenção } & \multicolumn{2}{c}{ Crime } \\
\hline Branco & Total & Percentual & Total & Percentual \\
Pardo & 551 & 23,7 & 189 & 27,5 \\
Preto & 1141 & 49 & 356 & 51,7 \\
\hline
\end{tabular}

Como se verifica, $27,3 \%$ dos presos correcionais era classificados como pretos. Se somarmos esse percentual ao de pardos, concluímos que os negros representavam $76,3 \%$ dos contraventores presos pela polícia e $71,8 \%$ dos presos pela prática de crimes. No segundo capítulo, na tabela 5, mencionei a informação extraída do Boletim de Polícia do Distrito Federal, segundo a qual negros correspondiam à maioria dos contraventores presos, mas, em relação ao crime, a prevalência era de brancos e imigrantes.

No Recife, a onda imigratória não teve o mesmo impacto que na cidade do Rio de Janeiro e, talvez por essa razão, a representação de estrangeiros em nossas estatísticas criminais seja baixíssima, como se vê na tabela abaixo:

Tabela 10: Entradas - CDR - crimes e contravenções - Nacionalidade - 1912 e 1914

\begin{tabular}{lcccc}
\hline & Nacionais & \multicolumn{2}{c}{ Estrangeiros } \\
\hline Ano & $\mathbf{1 9 1 2}$ & $\mathbf{1 9 1 4}$ & $\mathbf{1 9 1 2}$ & $\mathbf{1 9 1 4}$ \\
Crimes & 674 & 595 & 14 & 17 \\
Contravenções & 2264 & 2482 & 63 & 27 \\
\hline
\end{tabular}

Feitas essas observações mais genéricas, procurarei abaixo nos aproximar dos 'causos', o tanto quanto os limitados registros permitiram.

\subsection{A POLÍCIA ORDEIRA: VADIOS, DESORDEIROS, ÉBRIOS E MENORES}

Como se visualiza acima, na tabela n. 6, desordeiros, gatunos e vagabundos correspondem à maior parte das prisões efetuadas nos anos de 1914 e 1927. Adentrando um pouco mais de perto a realidade do bairro de Santo Antônio, esses números se mantêm, juntando-se a eles os ébrios. Segundo dados extraídos do livro de ofícios de delegados e subdelegados da $1^{\text {a }}$ Delegacia da Capital, somente na subdelegacia daquele bairro, nos meses de junho a dezembro de 1921, 2.048 pessoas foram presas, uma média de 292 por mês e praticamente dez por dia. Em todo o ano de 1921, foram 3.333 prisões.

\footnotetext{
${ }^{286}$ Fonte: APEJE, Fundo SG, volume 200. Relatório da Chefia de Polícia, 1912.
} 
Tabela 11: Prisões realizadas pela Delegacia de Santo Antonio - 1921 - Junho a Dezembro ${ }^{287}$

\begin{tabular}{lcccccccc}
\hline & Junho & Julho & Agosto & Setembro & Outubro & Novembro & Dezembro & Total \\
\hline Total & 247 & 322 & 284 & 302 & 335 & 278 & 280 & 2048 \\
Desordem & 82 & 100 & 48 & 77 & 98 & 95 & 95 & 595 \\
Vagabundos & 42 & 51 & 60 & 109 & 67 & 49 & 65 & 443 \\
Embriaguez & 48 & 59 & 53 & 32 & 78 & 40 & 0 & 310 \\
Gatunos & 37 & 35 & 36 & 35 & 31 & 48 & 55 & 277 \\
Ofensa à moral & 18 & 43 & 32 & 6 & 18 & 5 & 17 & 139 \\
Averiguação & 12 & 26 & 23 & 34 & 24 & 29 & 33 & 181 \\
Loucos & 4 & 0 & 0 & 2 & 0 & 3 & 5 & 14 \\
Suspeitos & 0 & 0 & 24 & 2 & 13 & 0 & 0 & 39 \\
Furto & 4 & 4 & 0 & 1 & 2 & 0 & 0 & 11 \\
Ferimentos leves & 0 & 2 & 2 & 0 & 3 & 0 & 0 & 7 \\
Assassinato & 0 & 0 & 0 & 0 & 0 & 1 & 0 & 1 \\
Outros & 0 & 2 & 1 & 0 & 1 & 0 & 0 & 4 \\
\hline
\end{tabular}

Os registros policiais praticamente não narram as ocorrências. Como esses contraventores não chegariam a responder propriamente a um processo, não havia inquérito ou diligências promovidas e, portanto, quase nada se sabe das condutas que levavam cada um deles à prisão. Em alguns casos, entretanto, delegados e subdelegados notificam as prisões à Chefia de Polícia, narrando brevemente o caso, e, noutras vezes, de forma mais pormenorizada. Já algumas informações relativas ao perfil desses detidos podem ser encontradas no livro de entradas e saídas da CDR. Com base nessas duas fontes, tentarei resgatar algumas das histórias sobre os malfeitores que movimentavam a polícia entre 1915 e 1930 na capital pernambucana.

No bairro de Santo Antônio, como demonstrado no primeiro capítulo, ocorria quase $50 \%$ das prisões de todo o Recife. Comumente descrito nos registros policiais como lugar de prostituição, de jogos de azar e de exploração de atividades ilícitas, será o cenário das ocorrências relatadas abaixo. O bairro é localizado no centro do Recife e, no início do século XX, era bastante frequentado. Seus sobrados costumavam alojar cafés e lojas no térreo e, nos andares superiores, residências. Muitas delas eram mapeadas pela polícia como casas de meretrizes e os cafés, também registrados por potencialmente servirem à exploração de jogos de azar.

Em um ofício de 26 de julho de 1921 encaminhado à Chefia de Polícia, o delegado Liberalino de Almeida informa que, próximo a cafés e hotéis situados, sobretudo, à rua

${ }^{287}$ Fonte: APEJE, Fundo SSP, livro 463. Livro de Ofícios de Delegados e Subdelegados da $1^{\text {a }}$ Delegacia de Polícia. 1921. Elaboração própria. 
Estreita do Rosário, “indivíduos dados à liberações alcóolicas e mulheres de vida virada, agitados pelo povinho, dansam ao toque da orquestra. Entre essas danças, porém, não me consta que exibam o "maxixe"”. E continua: "É provável, no entanto, que degenerem essa ordem de diversões em dansas licenciosas". Ao final ele conclui que tem "dado ordens no sentido de não consentirem com tais divertimentos em zonas que precisam de ser frequentemente policiadas porque os protagonistas dessas diversões incidem em constantes perturbações da ordem”, além de se dar em botequins situados nas ruas citadas - a Rua Estreita do Rosário e a Rua das Trincheiras - frequentados por desordeiros e $\operatorname{prostitutas}^{288}$.

O ofício nos permite refletir sobre vários aspectos da vida daquele bairro e do policiamento. Primeiramente, existiam danças, encontros, festas, diversões e muita gente nas ruas. A proibição ou a vigilância a todas essas práticas jamais logrou apaga-las por completo. Tampouco poderíamos supor que membros das forças policiais não fizessem parte delas, a despeito de o delegado informar serem ruas "frequentemente policiadas". Como verei adiante, eles muitas vezes compunham as cenas de indisciplina que deveriam perseguir.

Outro ponto a ser ressaltado diz respeito ao lugar ocupado pelo maxixe, uma dança negra. Liberalino afirma saber que prostitutas, pessoas alcoolizadas e o povinho dançam ao som das orquestras, mas tem dúvidas se essas danças degeneram no maxixe. Qualquer dança, em si, naquele bairro, com aquelas pessoas, parecia constituir, na visão daquelas autoridades, um foco de insegurança pública. Porém, mais grave ainda é quando essas danças se estragavam e enegreciam.

Embora certamente entre essas festividades encontrássemos homens e mulheres brancas, é de se notar que o marcador da degenerescência é um elemento da cultura negra, algo parecido com a oposição entre espiritismo branco e o negro e, conforme destacarei adiante, até mesmo entre a prostituição branca e a negra. Como lembra Boris Fausto,

na consciência coletiva, estão profundamente arraigadas as associações entre o negro e o ócio, a violência, a permissividade sexual. (...) Ser negro é um atributo negativo conferido pela natureza que só se desfaz parcial e excepcionalmente pela demonstração de características positivas: o devotamento ao trabalho, a fidelidade a algum branco protetor, a humildade $\operatorname{etc}^{289}$.

${ }^{288}$ APEJE, Fundo SSP, livro 463. Livro de Ofícios de Delegados e Subdelegados da $1^{\text {a }}$ Delegacia de Polícia. 1921.

${ }^{289}$ FAUSTO, Boris. Crime e cotidiano: a criminalidade em São Paulo (1880-1924). 2 ed. São Paulo: EDUSP, 2001, p. 67. 
Neste ponto, é preciso fazer um breve comentário sobre a capoeira, apesar de ela não aparecer no quadro das prisões. A perseguição a essa prática ocorreu ao longo de todo o século XIX, sendo a atividade proibida por meio de regulamentos policiais ou nas posturas municipais ${ }^{290}$. Em 1890, o Código Penal previu a "capoeiragem" como contravenção e os primeiros anos da República se tornaram conhecidos como de forte perseguição às maltas e a capoeiras famosos.

Naquele momento, a tônica era "ordem e progresso" e ao pacote de incivilizados composto de prostitutas, vagabundos, ébrios e jogadores se somavam os capoeiras. Mas, além das concepções higienistas e civilizatórias que guardava a repressão a essa prática, a prisão de capoeiras tinha um caráter fortemente político, nutrida pela oposição das Guardas Negras ao novo regime e adesão de muitas delas, além de maltas, à monarquia.

Como se referia Oscar Soares Macedo, “hoje essa gente [os capoeiras] pertence aos grupos carnavalescos, aos denominados cordões, ou são capangas eleitorais ao serviço dos políticos da mesma laia"291. Nos primeiros anos da República, no Recife, esse discurso ganhou forma.

O Partido Liberal tinha duas tendências: os cachorros e os leões. Os primeiros eram liderados por José Mariano, um abolicionista e criador do "Clube do Cupim”, organização clandestina que roubava negros na época da escravidão e os mandava para outros estados, onde conseguiam liberdade.

O grupo de Mariano, já no início da república, tinha uma composição heterogênea e contava com o apoio de homens negros, alguns dos quais, ex-capoeiras. Defendiam a monarquia e faziam oposição presente aos republicanos recifenses, os leões, muitos dos quais ligados a ex-senhores de escravo, que defendiam, por exemplo, uma indenização pelo fim da escravidão e a perda de suas propriedades, além de terem se posicionado de forma reticente à Lei Áurea. Os correligionários de Mariano eram comumente descritos como "as iras furibundas de uma malta inconsciente, composta por negros pobres, ignorantes e violentos" $" 292$.

Além da vinculação à política, no Recife, os capoeiras também integravam agremiações de frevo. Desde o ano de 1856, tentava-se proibir, na cidade, os desfiles desses

\footnotetext{
${ }^{290}$ HOLLOWAY, Thomas. O 'saudável terror': repressão policial aos capoeiras e resistência dos escravos no Rio de Janeiro no século XIX. Estudos Afro-Asiáticos, n. 16, 129-140, 1989, p. 135.

${ }^{291}$ SOARES, Oscar Macedo. [1910] Código Penal da Republica dos Estados Unidos do Brasil commentado. Brasília: Senado Federal, Superior Tribunal de Justiça, Coleção História do Direito, vol. 6, 2004, p. 776.

${ }^{292}$ OZANAM, Israel. Capoeira e capoeiras entre a guarda negra e a educação física no Recife. Dissertação de Mestrado. Programa de Pós-Graduação em História. UFPE. Recife, 2013, p. 56.
} 
grupos à frente das orquestras dos batalhões aquartelados ${ }^{293}$, mas sem sucesso. Os chapéus de sol abertos nas mãos, as hoje mais conhecidas sombrinhas de frevo, eram exibidas junto a passos e atitudes provocadoras, opondo grupos rivais pertencentes às orquestras de batalhões do exército.

Ademais, assim como as bandas da polícia militar permeiam a história do frevo, tinhase notícias de delegados e subdelegados que compartilhavam "o gosto pelos desfiles de bandas de música com outros capoeiristas" 294 . Por outro lado, os capoeiras chegavam a integrar os quadros policiais, sobretudo as polícias militares, pois, "além de um ordenado fixo, a farda abriria possibilidades de rendimentos extras e de atribuir ares de legalidade às ações violentas, muitas vezes realizadas a mando de chefes políticos"295.

Essas complexas relações entre políticos, polícia e capoeiras sugere que o problema da criminalização e repressão a essa prática merece um estudo realmente mais aprofundado. Todavia, um elemento parece claramente presente: as maltas e aqueles homens negros são frequentemente tratados como bestiais, ferozes, animalescos e perigosos, algo comum quando o assunto são as manifestações culturais negras.

Desse modo, embora no período estudado, de 1915 a 1930, não tenha aparecido, como disse, prisões por capoeira, essa breve digressão é fundamental porque, em certa medida, o medo e a repressão a eles foram fatos que constituíram a memória das forças policiais e a imagem da delinquência; o catimbó, o maxixe, a capoeira aparecem nos arquivos policiais reforçando estigmas e são como uma continuidade de sentidos negativos atribuídos ao ser negro.

Outro imbróglio cotidiano da polícia recifense era lidar com os vadios e os mendigos. A vadiagem foi construída como negação ao trabalho por uma longa tradição dos penalistas brasileiros. Tanto o Código Criminal do Império de 1830 como o da República, de 1890, previram a vadiagem ou a vagabundagem como atividade criminosa. "A vadiagem como parasitismo social e anti social é um fenômeno individual, social e econômico, punível quando anti social, isto é, quando pode constituir germen ou terreno preparado para os crimes", posicionava-se Oscar Soares ${ }^{296}$. João Vieira de Araújo, no mesmo sentido, via na

\footnotetext{
${ }^{293}$ DUARTE, Ruy. História Social do frevo. Rio de Janeiro: Editora Leitura S.A., 1968, p. 20.

${ }^{294}$ OZONAM, Israel. "Eu vou-me embora porque Apolônio da Capunga já anda na Boa Vista querendo prender gente": capoeira e polícia no Recife no início da República. Anais do XXVI Simpósio Nacional de História ANPUH • São Paulo, julho 2011, p. 7.

${ }^{295}$ OZONAM, Israel. "Eu vou-me embora porque Apolônio da Capunga já anda na Boa Vista querendo prender gente": capoeira e polícia no Recife no início da República. Anais do XXVI Simpósio Nacional de História ANPUH • São Paulo, julho 2011, p. 6.

${ }^{296}$ SOARES, Oscar Macedo. [1910] Código Penal da Republica dos Estados Unidos do Brasil commentado. Brasília: Senado Federal, Superior Tribunal de Justiça, Coleção História do Direito, vol. 6, 2004, p. 797.
} 
criminalização da vadiagem um mecanismo para evitar delitos mais graves, que a vida nas ruas poderia proporcionar:

Si por um lado as infrações que representam as contravenções não têm a gravidade que apresentam os crimes, por outro lado são fatos cuja repressão, embora mais branda quanto á penalidade, muito importa a um bom systema penal, desde que têm um effeito pratico, sinão prevenir efficazmente os crimes de natureza correspondente, tornal-os mais raros pelo effeito da intimidação causada pela punição dos factos mais ligeiros ${ }^{297}$.

Segundo a doutrina penal da época, havia mais de um tipo de vadio: aqueles que podiam, mas não queriam trabalhar e os que queriam, mas não podiam. Somente os primeiros eram considerados perigosos e criminalizados. Não porque vadiar fosse danoso em si - como ressaltam os penalistas-, mas porque a negação aos valores do trabalho, do esforço pessoal, dos padrões de convivência em sociedade denotava um sujeito capaz de adentrar a "alta" delinquência. $\mathrm{O}$ ato criminoso passa a ser secundário, frente à análise da personalidade, da periculosidade e das virtualidades do indivíduo que o pratica. Para Michel Foucault, olhar essas virtualidades e pretender corrigi-las é justamente a tônica da nova economia da pena inaugurada com a sociedade industrial e moderna:

Toda a penalidade do século XIX passa a ser um controle, não tanto sobre se o que fizeram os indivíduos está em conformidade ou não com a lei, mas ao nível do que podem fazer, do que são capazes de fazer, do que estão sujeitos a fazer, do que estão na iminência de fazer ${ }^{298}$.

Em outras palavras, é a manifestação do direito penal do autor. O sucesso da prisão consistiria justamente em prometer lidar com esses sujeitos. E se ela é o protótipo, no campo criminal, de uma sociedade disciplinar, o vadio seria, na sociedade, a figura ideal a ser disciplinável. "O vadio é, portanto, menos aquele a quem falta a subsistência e que se encontra por isso colocado fora, que aquele que, por sua própria vontade nega a oferta de trabalho que a terra nos faz tão generosamente" 299 .

${ }^{297}$ ARAÚJO, João Vieira de. Codigo Penal commentado theorica e praticamente. Rio de Janeiro, São Paulo: LAEMMERT \& C. Editores, 1896, p. 429.

${ }^{298}$ FOUCAULT, Michel. La société punitive. Cours au Collège de France. 1972-1973. Paris: EHESS, GALLIMARD, SEUIL, 2013, p. 85.

299 FOUCAULT, Michel. La société punitive. Cours au Collège de France. 1972-1973. Paris: EHESS, GALLIMARD, SEUIL, 2013, p. 49. Livre tradução de «Le vagabond est donc moins celui à qui manque la subsistance et que se trouve par là poussé dehors, que celui qui de sa propre volonté refuse l'offre de travail que la terre nous fait si généreusement ». 
De acordo com o Código Penal de 1890, os vadios seriam detidos e obrigados a assinar o "termo de bem viver"; caso reincidissem na prática, seriam presos. A ideia que subjazia essas previsões era a de que, uma vez advertidos, os vadios procurariam uma ocupação lícita. Caso não o fizessem, seriam presos e, assim, no cárcere, teriam suas almas corrigidas. Punir vagabundos e desordeiros era uma forma, portanto, de normalizá-los.

Na prática, não era bem assim. Vagabundos eram presos e, poucos dias depois, soltos. Dormiam algumas noites na prisão, levavam alguns baculejos e, em seguida, por ato de autoridade da polícia, voltavam às ruas, de onde seriam novamente afastados, repetindo aquele ciclo, tantas vezes quanto os policiais julgassem necessário. Adiante aprofundarei esse argumento.

Dentre os vadios que podiam, mas não queriam trabalhar estavam os mendigos, que também eram classificados entre indigentes e doentes ou simplesmente aproveitadores da caridade pública. A mendicância ocupa páginas e páginas dos relatórios das chefias de polícia. Em 1927, Eurico de Souza Leão especifica o caminho percorrido por um mendigo recolhido pela polícia nas vias públicas:

Realizada a detenção de um mendigo, é ele submetido a exame medico afim de, irrefutavelmente, ser apurada a sua capacidade ou não para o trabalho. Enfermo, sem poder ganhar a vida, não tendo quem o ampare, é o mendigo entregue ao 'Dispensário dos Pobres', onde encontra sua subsistência assegurada. Na hipótese, porém, de se tratar de um indivíduo portador de moléstia incurável, é recolhido ao Asylo de Mendicidade, donde só se pode retirar depois de completamente restabelecido, o que é comunicado a delegacia encarregada do serviço de mendicância pelo diretor do citado estabelecimento de caridade, o ilustre Dr. Francisco Clementino, cujo concurso à repressão da mendicância saliento aqui com encômios. Se o indivíduo, entretanto, dispõe de capacidade para o trabalho, é compelido pelos meios legais a procurar um modo honesto de vida, e, na reincidência, identificado como vagabundo é recolhido à Casa de Detençao ${ }^{300}$.

Em um fato narrado no ofício de 31 de março de 1925, encaminhado pelo delegado da $1^{\text {a }}$ delegacia da capital, Affonso Neves Batista, à Chefia de Polícia, verifica-se que a repressão à mendicância era uma atividade importante das forças policiais. O ofício, na verdade, narrava um conflito entre o subdelegado de Santo Antonio e o motorista da Assistência policial. No dia 30 de março, o subdelegado teria dado ordens para prender cinco indivíduos que foram encontrados "mendigando à caridade pública nas ruas daquele distrito". Ocorre que, ao

${ }^{300}$ APEJE, Fundo Secretaria de Justiça, Livro 202, Relatório da Chefia de Polícia, 1928, p. 8-9. 
solicitar o carro da Assistência Policial para realizar o transporte dos mendigos, o motorista teria se recusado dizendo que só fazia o transporte por ordem de superior. O subdelegado pedia, então, providências para poder "reprimir a mendicância" a contento ${ }^{301}$.

Aos vagabundos e mendigos se somavam os desordeiros, figura inexistente no Código Penal, mas presente na prática policial. Beber muito em público, praticar algazarras, farras, falar alto, citar palavrões em voz alta, tudo isso poderia levar alguém a ser preso por desordem. Foi o caso, no dia 8 de fevereiro de 1922, de membros do exército que estariam pelas ruas, no centro do Recife, fazendo desordens e mostrando armas, no que foram advertidos por agentes de polícia e guardas civis. Acabaram provocando esses últimos, gerando um conflito entre as forças policiais ${ }^{302}$.

Os ébrios se confundem e também aparecem como desordeiros. Em 04 de novembro de 1915, o subdelegado de Santo Antônio comunica a prisão de um rapaz de nome Tarcilo de Tal - como escrito no documento - em frente ao hotel Abrantes, o qual estaria em visível estado de embriaguez e promovendo desordens. Após a sua condução à delegacia, Fenelon Moreira da Silva Santos compareceu ao local e, "em termos ameaçadores, se opõs tenazmente à entrada do referido Tarcilo para o xadrez". Fenelon agiu de modo truculento com os policiais, usando uma faca para provocar um sargento e um cabo que se encontravam na delegacia e, por essa razão, também foi preso ${ }^{303}$.

Em 06 de fevereiro de 1918, deu-se uma cena parecida com a anteriormente escrita. Francisco Ferreira da Silva, marinheiro do Cruzador "Floriano", foi preso por ordem do subdelegado de Santo Antonio, José Primo d'Oliveira, porque, "embriagado, promovia desordem" e usava de um vocabulário "excessivamente indecente", conforme informações contidas no ofício encaminhado por aquela autoridade ao $1^{\circ}$ Delegado da Capital, Arnulpho Lins e Silva.

Em um ofício de 26 de abril de 1927, o $1^{\text {o }}$ delegado da capital, Maurício Guimarães, informa a prisão, no dia anterior, de João Malaquias Bispo, por embriaguez, estando este à disposição daquela autoridade.

Além de desordeiros, ébrios e vadios adultos, havia uma enorme preocupação com os menores que também perambulavam pelas ruas. Em 1922, Arthur da Silva Rego, chefe de

\footnotetext{
${ }^{301}$ APEJE, Fundo SSP, livro 466. Relatórios de delegados e subdelegados de polícia, $1^{\text {a }}$ Delegacia da Capital, 1925.

${ }^{302}$ APEJE, Fundo SSP, livro 468. Livro de Ofícios de Delegados e Subdelegados da $1^{\text {a }}$ Delegacia de Polícia. 1922.

${ }^{303}$ APEJE, Fundo SSP, livro 455, Livro de Ofícios de Delegados e Subdelegados da $1^{\text {a }}$ Delegacia de Polícia, 1915.
} 
polícia, lembra que as ruas do Recife estavam impregnadas de menores sem pais, sem família, abandonados e se entregando ao ócio e à vagabundagem. "O analfabetismo e ankylostomiase devoram-lhe os organismos. Dentro em pouco a aversão ao trabalho está agravada pela mísera condição física", e, diante de tal problema, era fundamental a criação de uma Colônia Correcional de Menores, de preferência em local afastado da CDR, para evitar que esses menores aprendessem com os criminosos ante a inevitável "Lei da Imitação", de que falava Gabriel Tarde ${ }^{304}$.

De fato, o número de menores recolhidos à CDR é bastante alto, conforme os dados de 1912:

Tabela 12: Entradas - CDR por idade - $1912^{305}$

\begin{tabular}{lcccc}
\hline & Crime & Percentual & Contravenção & Percentual \\
\hline Até 15 anos & 21 & 3,1 & 276 & 11,9 \\
De 15 a 20 anos & 162 & 23,5 & 706 & 30,3 \\
De 20 a 25 anos & 174 & 25,3 & 579 & 24,9 \\
De 26 a 30 anos & 114 & 16,6 & 303 & 13,0 \\
De 31 e 35 anos & 67 & 9,7 & 143 & 6,1 \\
De 36 a 40 anos & 66 & 9,6 & 138 & 5,9 \\
De 41 a 45 anos & 28 & 4,1 & 58 & 2,5 \\
De 46 a 50 anos & 18 & 2,6 & 57 & 2,4 \\
Maiores 50 anos & 37 & 5,4 & 51 & 2,2 \\
Ignoradas & 1 & 0,1 & 16 & 0,7 \\
Total & 688 & 100 & 2327 & 100 \\
\hline
\end{tabular}

Apenas neste ano, 276 pessoas com menos de 15 anos foram recolhidas à CDR com imputação da prática de alguma contravenção. Se a elas se agregam os indivíduos com idade até 20 anos, esse número sobe para 982, totalizando 42,2\% das detenções por esse tipo de infração. Alguns anos depois, esse percentual era bem parecido:

Tabela 13: Entradas e saídas por idade - CDR - 1920 (SET/OUT) - Percentual ${ }^{306}$

\begin{tabular}{lcccc}
\hline & Mulher & Homem & 9,9 \\
\hline Menores de 14 anos & 0 & 0,0 & 18 & 17,6 \\
De 14 a 18 anos & 1 & 3,6 & 32 & 36,8 \\
De 18 a 25 anos & 6 & 21,4 & 67 & 23,6 \\
De 25 a 35 anos & 9 & 32,1 & 43 & 8,8 \\
Maiores de 35 anos & 10 & 35,7 & 16 & 3,3 \\
\hline Ilegível & 2 & 7,1 & 6 & \\
\hline
\end{tabular}

${ }^{304}$ APEJE, Fundo Secretaria de Justiça, Livro 200, Relatório da Chefia de Polícia, 1923, p. 12.

${ }^{305}$ Fonte: APEJE, Fundo SG, volume 200. Relatório da Chefia de Polícia, 1912.

${ }^{306}$ Fonte: APEJE, Fundo SSP, Casa de Detenção do Recife. Livro de entradas e saídas. 1920. 
Em 1920, dos 182 homens recolhidos entre setembro e outubro, 50 tinham até 18 anos, isto é, cerca de $24 \%$, repetindo um padrão semelhante ao verificado em 1912. Conforme dito acima, a questão do menor foi objeto de preocupação da polícia ao longo de todo o período pesquisado nas cidades brasileiras. Liana de Paula destaca que "naquele contexto de rápidas transformações e acelerado crescimento urbano, a presença de crianças e adolescentes pelas ruas da cidade, com suas farras e molecagens, passou a chamar a atenção da imprensa"307.

O discurso oficial a respeito desses menores era amplamente correcionalista e entendia ser fundamental a construção de escolas ou outros centros educativos para onde eles seriam enviados e transformados em trabalhadores honestos. Nas primeiras décadas do século XX, várias dessas escolas correcionais surgiram, como foi o caso do Instituto Disciplinar de São Paulo, em 1902 e a Escola Correcional do Recife, em 1909; outro destino comum desses menores eram as Escolas de Aprendizes Marinheiros ${ }^{308}$. O quanto, assim como as prisões para adultos, elas efetivamente corrigiam é também uma pergunta a ser analisada depois.

Por ora e para concluir este ponto, é fundamental lembrar que tanto a "questão do menor", como o dos "malfeitores" adultos é bastante racializada. Não apenas em razão das diversas percepções partilhadas no período sobre a oposição civilização e barbárie coincidindo com branquitude e negritude, como também pelos resultados da seleção policial e do sistema de justiça criminal.

Quando cruzamos a informação da idade com a cor dos "menores", verificamos que 66\% (33 de 50) deles eram pretos ou pardos, no ano de 1920 e, em sua maioria, homens. Era o caso de Antonio Sylvestre dos Santos, de 14 anos, registrado no Livro como preto-fulo, que foi preso pelo subdelegado de Santo Antonio no dia 4 de setembro de 1920 e solto somente no dia 23 de outubro do mesmo ano. Mais de um mês de prisão correcional por ser gatuno. Também de Francisco Pedro, 12 anos, preto, foi preso por desordem no dia 7 de setembro daquele ano e solto apenas no dia 22 de dezembro do mesmo ano. Mais de três meses de prisão correcional ${ }^{309}$.

\footnotetext{
${ }^{307}$ PAULA, Liana de. Da “questão do menor" à garantia de direitos. Civitas, Porto Alegre, v. 15, n. 1, p. 27-43, jan.-mar, 2015, p. 28.

${ }^{308}$ Uma pequena nota sobre essa escola. As forças armadas representavam a esperança de disciplinamento de muitos desses indivíduos que, por qualquer razão - da pobreza à indisposição ao trabalho - eram vistos como potenciais trabalhadores, mas careciam de educação. A Escola de Aprendizes Marinheiro recebia muitos menores varridos praticamente das ruas e lá postos involuntariamente. Talvez esse dado explique os muitos atos de indisciplina promovidos por marinheiros nas ruas do Recife, no período, mas também explique o fato de essa força armada ser a mais negra dentre as três existentes no Brasil.

309 APEJE, Fundo SSP, Casa de Detenção do Recife. Livro de entradas e saídas. 1920.
} 
Padrão semelhante foi o de uma prisão realizada em 1926 e comunicada, com detalhes, ao chefe de polícia. Manoel Pereira da Silva, com 10 anos de idade, solteiro, de côr parda, jornaleiro, com 1 metro e $35 \mathrm{~cm}$, cabelos castanhos e corridos, rosto oval, imberbe, olhos pretos, nariz grosso, boca e corpos regulares, todos os dentes e analfabeto foi recolhido no dia 27 de setembro de 1926 , de ordem do $3^{\circ}$ delegado do $1^{\circ}$ distrito da capital como vagabundo e posto em liberdade no dia 4 de janeiro de 1927 por ordem do chefe de polícia. O perfil, como se vê, é parecido com o da criança P6279, que deu entrada na CDR em 1927 e cuja foto aparece no anexo 9.

Entre adultos, a situação era semelhante, embora a falta de informações relativas à cor do preso - presente apenas no Relatório da Chefia de Polícia de 1912, como dito acima dificulte a tarefa de compreender o perfil desses presos. Na tabela 9 , há a informação de que, naquele ano, $72,6 \%$ das prisões por crime era de pretos e pardos, percentual que chega a 76,3\% para as contravenções. No livro de entradas e saídas da CDR, essas informações estão presentes e, embora seja praticamente impossível tratar dos dados das mais de três mil prisões registradas em cada ano, consultamos dois meses do ano de 1920 para ilustrar o nosso argumento. A prevalência de pardos e pretos verificada em 1912 se mantém. Exceto para o caso da loucura, em que a representação de brancos (24 pessoas) é comparável a de pardos e pretos (26 pessoas).

Tabela 14: Entradas - CDR - 1920 (setembro e outubro) - Motivo/cor ${ }^{310}$

\begin{tabular}{lccccc}
\hline & Branca & Parda & Preta & Ilegível & Total \\
\hline Catimbó/desordem & 0 & 3 & 1 & 0 & 4 \\
Desordem & 25 & 28 & 21 & 0 & 74 \\
Distúrbios & 1 & 0 & 0 & 0 & 1 \\
Embriaguez & 5 & 1 & 1 & 0 & 7 \\
Embriaguez/ desordem & 1 & 0 & 1 & 0 & 2 \\
Embriaguez/ofensa à moral & 0 & 0 & 1 & 0 & 1 \\
Gatuno & 21 & 23 & 21 & 1 & 65 \\
Gatuno/ desordem & 0 & 1 & 0 & 2 & 1 \\
Loucura & 24 & 16 & 0 & 0 & 52 \\
Ofensa à moral & 2 & 0 & 1 & 0 & 3 \\
Vagabundagem & 2 & 1 & 0 & 11 & 4 \\
Ilegível & 2 & 0 & 44 & 14 & 232 \\
Total & 83 & 55 & & 0 \\
\hline
\end{tabular}

${ }^{310}$ APEJE, Fundo SSP, Casa de Detenção do Recife. Livro de entradas e saídas. 1920. 
No caso da desordem e da gatunagem, o percentual de pretos e pardos chega a 56,3\% e $67,6 \%$, respectivamente.

Já a gestão da loucura merece uma análise à parte, posto que, nos arquivos policiais, as informações são muito parcas. O que se pode dizer, entretanto, é que a loucura é uma chave importante para entender o controle sobre mulheres brancas, porque eram elas, principalmente, as presas por essa razão. Aqui, os discursos médico e jurídico se harmonizam e patologizam comportamentos os mais diversos, incluindo aqueles que implicavam simples fuga do padrão esperado dessas mulheres, como o adultério, o aborto, a gravidez fora do casamento, a negativa em casar etc. Thais Dûmet ressalta que as doenças mentais, notadamente a histeria

$\operatorname{Era}(m)$ quase uma justificativa para alguns atos inaceitáveis para as mulheres. (...) Essa era uma armadilha importante a ser considerada, que justificava a contenção dessas mulheres que mantinham comportamentos inadequados. Ou eram criminalizadas ou medicalizadas. Em qualquer um dos casos eram segregadas socialmente, em prisões, hospícios ou conventos, ou, no mínimo, vistas como incapazes e, por isso, desconsideradas em suas ideias e vontades ${ }^{311}$.

Por fim, é fundamental mencionar que o jogo também era um objeto de inquietação das forças policiais. A Lei Estadual 1.275 proibiu, em Pernambuco, os jogos de azar, dentre eles, as apostas, o jogo do bicho e o baralho. Além disso, o Código Penal tipificava a conduta como uma contravenção. Dentre os diversos tipos de jogos, o do bicho é especialmente mencionado pelos chefes de polícia, fato que havia sido observado por Clarissa Nunes Maia e que pode ser explicado em razão de ser, dessas práticas, a mais popular:

seria o jogo do bicho, no início da República, que receberia maior atenção das autoridades pela penetração que tinha entre a gente do povo. Em 1905, o então chefe de polícia Monoel dos Santos Moreira, colocava como sendo uma de suas prioridades o combate a este jogo, umas das causas, ao seu ver, do aumento da criminalidade no Recife $^{312}$.

No relatório do Chefe de polícia Eurico de Souza Leão, publicado em 1928, ele chega a afirmar, com bastante otimismo, que o jogo do bicho fora extinto. "Esta modalidade da

\footnotetext{
${ }^{311}$ FARIA, Thaís Dumêt. Memória de um silêncio eloquente: a criminalização das mulheres no Brasil na primeira metade do século XX. Tese de doutorado. Programa de Pós-Graduação em Direito. Universidade de Brasília, Brasília, 2013, p. 50.

312 MAIA, Clarissa Nunes. Policiados: controle e disciplina das classes populares na cidade do Recife, 18651915. Tese de doutorado. Programa de Pós-Graduação em História da UFPE, 2001, p. 26.
} 
jogatina tinha-se de tal forma enkystado no animo das classes baixas, que tomara a feição de verdadeira praga. (...) Mas o jogo foi extinto!”313. Parece que não foi bem assim...

Ao longo dos anos pesquisados, entretanto, não era apenas o jogo do bicho o alvo das investidas policiais. As casas de tavolagem, no Recife, onde se jogava tabuleiro, baralho, se faziam apostas etc eram frequentemente "varejadas" por policiais, os quais apreendiam roletas, cartelas numeradas, caixas de baralho, mesas, cadeiras, panos numerados e, em seguida, interditavam o estabelecimento. No ano de 1917, verificamos esse procedimento se repetir dezenas de vezes. No Relatório da Chefia de Polícia de 1918, consta a informação de que, em 1917, 1.787 objetos foram apreendidos em casas de tavolagem, número que passou para 828 em 1918.

A redução no número de apreensões, como é de se esperar, não se deve à eliminação da atividade, mas aos esforços direcionados a isso. Tanto é assim que, nos anos seguintes, as casas de tavolagem continuam a ser varejadas e fechadas, voltando, a funcionar logo depois. A gestão dessa ilegalidade deve ter comportado uma série de acordos com proprietários e usuários, já que há uma verdadeira oscilação em termos de repressão. Porém, não encontramos dados concretos para confirmar essa hipótese.

Fato é que, no discurso policial, assim como acontecia com o vagabundo, o jogador era entendido como alguém de alma fraca e suscetível a incorrer em condutas mais graves, por um vício de moralidade. Quando Antônio Guimarães, chefe de polícia, justifica a prioridade que deu ao combate ao jogo no ano de 1917, o faz afirmando que essa atividade era um mal que se alastrava pela capital e pelo interior, consistindo, ainda, "no primeiro passo para o crime". Conclui, então, que "o jogador habitual é sempre um vencido moralmente, susceptível de incorrer na reincidência, porque habituado de viver do jogo e não encontrando um meio honesto de subsistência"314.

A polícia ordeira é, portanto, um importante projeto das chefias de polícia pernambucanas do período. Entre práticas e discursos, procuram essas autoridades demarcar os sujeitos, na sociedade, que eram a imagem da incivilidade, da barbárie e do atraso. Serão eles os principais alvos da investida policial, a qual, entretanto, longe de ser apenas repressora, comportará os mais diversos tipos de interação, dentre acordos e atos de pura truculência, assunto de que tratarei no próximo capítulo. Antes, porém, mencionarei outras duas feições das forças policiais do período: a polícia moral e a polícia política.

\footnotetext{
313 APEJE, Fundo Secretaria de Justiça, Livro 202, Relatório da Chefia de Polícia, 1928.

314 APEJE, Fundo SSP, Caixa 2. Relatório da Chefia de Polícia, 1918.
} 


\subsection{A POLÍCIA MORAL: AS MULHERES E O CONTROLE PENAL FORMAL}

Inicio este ponto contando quatro histórias e fatos que são bastante elucidativos dos argumentos que pretendo desenvolver adiante.

Lúcia Lins de Sant'Ana, meretriz, foi presa em 24 de julho de 1917, por volta das 23h, na Rua das Trincheiras, por ordem do subdelegado de Santo Antônio, José Primo d'Oliveira, porque "além de embriagada, ofendia à ordem publica".

Em 23 de março de 1918, a meretriz Antônia Barbosa de Lyra, 19 anos, "não sabendo ler e nem escrever" foi presa para averiguação. O assunto era a filha de Antônia, Josepha Barbosa, que estava morando com ela no $1^{\circ}$ andar do número 185 do Pátio do Carmo. Interrogada por um escrivão e um delegado de polícia, Antônia explicou que sua filha nascera em 1913 e, desde então, não podendo mantê-la em casa em razão de seu ofício de meretriz, Josepha teve outros lares. Primeiramente, a interrogada informou que pagava cerca de 10 mil reis por mês a uma mulher de nome Nara, moradora de sua cidade natal, Nazareth, para ficar com Josepha. Depois, sua filha passou aos cuidados de uma irmã, Severina Barbosa. Quinze dias antes da averiguação, Josepha teria sido trazida de Nazareth para o Recife, por Severina, estando, desde então, com a sua mãe. "Nada mais disse e nem lhe foi preguntado", concluíram o escrivão e o delegado, encaminhando a filha de Antônia à Chefia de Polícia para "os devidos fins".

Os "devidos fins" devem ter sido o destino tomado, em 5 de setembro de 1916, pela menor Maria das Dores e Silva, encaminhada ao "juiz de órfãos", em razão de ter sido encontrada na casa da meretriz Marieta de Tal, na Rua Largo do Rosário, também no Recife.

Uma década após esses acontecimentos, em agosto de 1927, foi criada uma nova seção policial, a "Locação de Domésticos". O Chefe de polícia, Eurico de Souza Leão, justificava a existência do novo serviço e explicava a sua finalidade:

Nem toda gente compreende a necessidade de que um doméstico seja examinado pela polícia. Não se trata tão só da garantia de sua probidade, da facilidade que terá a Polícia em encontrar o empregado culpado de seu acto desonesto. Muito mais proveitosa é a observância dessa exigência policial quando se reflete na possibilidade, sempre realizável, de se admitir ao convívio íntimo da família uma pessoa sofredora de moléstia incurável e contagiosa. Dos candidatos, muitos já prestando seus serviços em casa de família, não pequena quantidade foi recusada por estar afligida de enfermidades como tuberculose, lepra, cancro etc ${ }^{315}$.

\footnotetext{
${ }^{315}$ APEJE, Fundo Secretaria de Justiça, Livro 202, Relatório da Chefia de Polícia, 1928, p. 16-17.
} 
Embora o Chefe de polícia fale o tempo inteiro no masculino, os domésticos eram, em verdade, domésticas. No período que vai de agosto a dezembro de 1927, 2.662 mulheres e 607 homens foram registrados pela polícia e avaliados pelo Departamento de Saúde e Assistência Pública. Ao ver a tabela com esses números e perceber a enorme quantidade de mulheres que passaram pelo constrangimento de serem examinadas, tocadas e analisadas como animais, perguntei-me sobre o tratamento que empregadores e empregadoras dispensavam a elas e sobre o que tinha mudado após 1888.

O medo da sujeira e do risco que essas mulheres representavam possuía uma memória bem recente, posto que, no final do século XIX, no Recife, surgiu uma postura municipal que obrigava amas-de-leite a serem submetidas, ao menos uma vez ao mês, a exames na Secretaria de Polícia, onde seriam avaliadas por médicos ${ }^{316}$, prática que materializava os saberes médicos que apontavam para a amamentação como um problema dada a falta de higiene das mulheres negras. Antes de constituir uma inovação, o Serviço de Locação de Domésticos era uma continuidade.

Essas narrativas sugerem que a polícia possuía uma participação bastante ativa na vida dessas mulheres. Essa afirmação foi, de certa forma, trabalhada no capítulo anterior, quando discutimos a procura de pessoas e famílias pobres e negras às unidades policiais para dirimirem as pequenas ou grandes dificuldades do dia-a-dia. Aqui, entretanto, dedicamo-nos a entender a interferência policial repressiva, não rara e não incomum no período.

Na tabela 8 , acima, verificamos que $18 \%$ das prisões por contravenção, no ano de 1914, são de mulheres. O perfil dessas presas não consta nas fontes pesquisadas para aquele ano. Entretanto, obtive os dados relativos à cor e ao sexo dos indivíduos que deram entrada nos meses de setembro e outubro de 1920 na Casa de Detenção do Recife. Naqueles meses, 31 mulheres foram recolhidas. Dessas, 18 eram pardas e pretas, 12 eram brancas e em 1 caso a informação está ilegível.

No caso das 12 mulheres brancas, 10 foram recolhidas como "loucas", 1 por ofensa à moral e, em um caso, o motivo está ilegível. Já entre as mulheres pardas e pretas, 11 foram detidas como loucas e 7, por razões diversas e relacionadas à desordem pública: embriaguez, catimbó e desordem. Para serem presas como vadias, embriagadas ou prostitutas essas mulheres ocupavam o espaço público, trabalhavam e sustentavam suas famílias, como no caso de Antônia, a mãe de Josepha. Os dados quantitativos são muito precários e reduzidos, mas,

\footnotetext{
316 MAIA, Clarissa Nunes. Policiados: controle e disciplina das classes populares na cidade do Recife, 1865 1915. 252 f. Tese (Doutorado em História) - Universidade Federal de Pernambuco, Recife, 2001, p. 59.
} 
somados aos outros elementos, sugerem que mulheres negras estavam sujeitas à repressão policial de modo diferenciado das mulheres brancas.

No boletim da Polícia Civil do Distrito Federal, há apanhados que dialogam bastante com essa conclusão. A tabela abaixo torna perfeitamente congruente a afirmação de Bretas, segundo a qual "a imagem típica da mulher vadia é a mulher negra; ao passo que a imagem típica do homem vadio é o estrangeiro branco"317318. No Recife, apontei para dados que demonstram que o vadio também é um homem negro.

Tabela 15: Prisões efetuadas pela polícia do DF por sexo/cor/motivação - $1907\left(1^{\circ} \text { Trimestre }\right)^{319}$

\begin{tabular}{lccccc}
\hline & Brasileira & Estrangeira & Branca & Mestiça & Preta \\
\hline Sociedade secreta & 0 & 1 & 1 & 0 & 0 \\
Mendicidade & 0 & 1 & 2 & 0 & 0 \\
Embriaguez & 7 & 0 & 0 & 1 & 6 \\
Embriaguez e vadiagem & 14 & 1 & 4 & 4 & 4 \\
Vadiagem & 189 & 11 & 33 & 74 & 93 \\
Vagabundas reincidentes & 5 & 1 & 2 & 2 & 2 \\
Capoeiragem & 2 & 0 & 0 & 2 & 0 \\
Sem motivo especificado & 3 & 3 & 3 & 1 & 2 \\
\hline
\end{tabular}

Voltando às mulheres, somente em um trimestre de 1907, foram presas 189 mulheres por vadiagem, sendo $49,2 \%$ delas, pretas.

Os quatro casos citados acima, os dados advindos da pesquisa com as fontes policiais e muitas provocações realizadas, sobretudo, por criminólogas ou feministas negras, conduziram-me a pensar em alguns limites teóricos com os quais normalmente trabalha a criminologia crítica a questão da mulher. Como adiantamos acima, havia muitas mulheres vivendo sob o certo policial, a maioria delas, negras. O que isso teria a nos dizer?

Um dos principais pressupostos das teorias criminológico-críticas de cunho feminista é o de que as mulheres estariam sujeitas primordialmente a formas de controle social informal, isto é, aqueles exercidos sem base normativa legal, como define Elena Larrauri. É o caso da educação religiosa, escolar e familiar. ${ }^{320}$ Essa definição exclui o sistema punitivo e, com ele, a polícia, pois estes intercederiam apenas residualmente quando aquelas outras instâncias falhassem.

\footnotetext{
317 Não custa lembrar que, conforme já asseverado acima, ao contrário do que ocorria no Distrito Federal, a imagem do homem vadio no Recife também é de um homem negro, já que, pelas bandas de cá, vivenciamos menos fortemente, no período, as ondas imigratórias.

318 BRETAS, Marcos Luiz. Ordem na cidade: o exercício cotidiano da autoridade policial no Rio de Janeiro: 1907-1930. Rio de Janeiro: Rocco, 1997, p. 87.

${ }^{319}$ Fonte: Boletim Policial do Distrito Federal - Ano 1, Volume 1, Ano 1907/Elaboração própria

${ }^{320}$ LARRAURI, Elena. Mujeres y sistema penal: violencia doméstica. Montevideo, Buenos Aires: Editorial B de F, 2008, p. 13 .
} 
Esse apanhado pressupõe que as mulheres ocupam, majoritariamente, o espaço doméstico e inserem-se como peça da estrutura patriarcal desempenhando papel de boas filhas e mães, estando, assim, pouco sujeitas às dinâmicas da vida "pública", incluindo o crime e a criminalização.

O grande problema, entretanto, dessa formulação, comum nas principais teorias feministas desenvolvidas nas décadas de 1960 e 1970, é trabalhar a categoria mulher silenciando os recortes de classe e raça, como se elas estivessem todas unidas por sua womanhood. Como se o sistema de dominação masculina, o patriarcado, exercesse sobre qualquer mulher, independentemente do tempo histórico, do lugar e da posição social em que ela se insere, o mesmo tipo de violência ${ }^{321}$.

Bell hooks, em seu "Feminism is for everybody", ironiza esses apanhados dos movimentos feministas, que evocavam essa união das mulheres, quando, em verdade, sequer tratavam da condição das mulheres negras ${ }^{322}$. No mesmo sentido, serão as críticas de Angela Davis, para quem o lugar da mulher negra foi o do trabalho duro, o da administração das funções domésticas, o da objetificação do corpo e a exploração sexual, mas também o da resistência e não subjugação; de toda sorte, um lugar social muito diferente do ocupado pela mulher branca, que a colocou na linha de frente nos processos de criminalização e policialização da vida ${ }^{323}$.

No esteio, como adverte Sueli Carneiro, "um feminismo negro, construído no contexto de sociedades multirraciais, pluriculturais e racistas - como são as sociedades latinoamericanas - tem como principal eixo articulador o racismo e seu impacto sobre as relações de gênero" 324 . Ao fazê-lo, não apenas reivindica o "ponto de vista situado" das mulheres negras, como também aponta para a necessidade de se repensar as categorias de patriarcado e relações de gênero a partir do racismo, conduzindo a questionamentos inexoráveis para a criminologia, inclusive a crítica.

Muito há, ainda, a se investigar, mas algumas leituras, no Brasil, já apontam para esses novos caminhos. Primeiramente, considerando que a mulher negra esteve fora do espaço

\footnotetext{
${ }^{321}$ PISCITELLI, Adriana G. Gênero em perspectiva. Cadernos Pagu, v. 11, p. 141-157, 1998.

${ }^{322}$ HOOKS, bell. Feminism is for everybody: passionate politics. Cambridge: South End, 2000, p. 56.

${ }^{323}$ Ela afirma: "Following the dominant model for women's prisons during that period, Alderson's regimes were based on the assumption that 'criminal' women could be rehabilitated by assimilating correct womanly behaviors, that is, by becoming experts in domesticity-especially cooking, cleaning, and sewing. Of course, training designed to produce better wives and mothers among middle-class white women effectively produced skilled domestic servants among black and poor women. DAVIS, Angela. Are prisons obsolete? New York : Seven Stories Press, 2003, p. 64.

${ }^{324}$ CARNEIRO, Sueli. Enegrecer o feminismo: a situação da mulher negra na América Latina a partir de uma perspectiva de gênero. Disponível em < https://www.geledes.org.br/enegrecer-o-feminismo-situacao-da-mulhernegra-na-america-latina-partir-de-uma-perspectiva-de-genero/> Acesso em 12 ago 2017.
} 
doméstico desde a escravidão até as revoluções industriais, representando importante contingente da força de trabalho, estavam e estão submetidas às formas de controle policial do espaço público. Talvez isso explique o fato de $18 \%$ das prisões por contravenção no Recife ser de mulheres.

Por outro lado, como destaca Naila I. C. Franklin, no Brasil, no século XIX, a mulher negra era uma propriedade e seu corpo algo a ser explorado, inclusive, sexualmente ${ }^{325}$. Não se tratava de submetê-la à posição de passiva sexual e de frágil, de frígida e essencialmente mãe, como se dava em relação às mulheres brancas, mas o oposto disso. Talvez essa falta de "pudor" em relação aos corpos negros, justificasse a exequibilidade de um projeto como o de "Locação de Domésticos". Em menos de seis meses, como visto, mais de 2.600 corpos foram vasculhados para verificar se padeciam de cancro ou outras doenças infecciosas... Igual medida seria, certamente, impensável em relação a outras trabalhadoras, como telefonistas ou datilógrafas, cujo perfil difere do da empregada doméstica.

Aliás, no ano de 1917, uma charge publicada no jornal "Avança", envolvendo telefonistas, acabou virando um caso de polícia, mas não da polícia repressiva e, sim, daquela protetora da honra. Na charge (anexo 10), uma conversa entre dois homens é narrada, ficando um deles bastante interessado por uma telefonista. Insinuações de que essas mulheres pudessem ser prostitutas são feitas e o caso acabou gerando um abaixo-assinado das trabalhadoras da empresa "Telephone Company of Pernambuco LTD”, as quais denunciam à Chefia de Polícia a campanha 'contra as suas honras', que as prejudicam perante "seus chefes e toda a sociedade pernambucana". O caso foi resolvido quando o delegado do $1^{\circ}$ distrito convocou à delegacia o responsável pelo jornal e o intimou a parar com a "campanha de difamação a que aludem as referidas senhoras”. A defesa à honra dessas mulheres parecia fundamental, porque o recato é o ideal que se lança sobre elas; tampouco se pode imaginar que elas viessem a constituir o perfil alvo do serviço de "Locação de Domésticos".

Falando em mulheres trabalhadoras, portanto, diversos eram os tratamentos dispensados quando fossem brancas ou negras. Sobre estas recaía muito mais facilmente intervenções do tipo a do serviço de fiscalização, desenvolvido pela polícia pernambucana. Essa falta de pudor é hoje estudada na criminologia crítica como uma das facetas do tratamento que o sistema punitivo dispensa às mulheres negras.

\footnotetext{
${ }^{325}$ FRANKLIN, Naila Ingrid Chaves. Raça, gênero e criminologia: Reflexões sobre o controle social das mulheres negras a partir da criminologia positivista de Nina Rodrigues. Dissertação de mestrado. Programa de Pós-Graduação em Direito. Universidade de Brasília, 2017.
} 
Ana Luiza Flauzina lembra, por exemplo, das várias formas de exploração sexual na dinâmica do cárcere, seja através das revistas vexatórias, seja por meio da prostituição praticamente institucionalizada naquele espaço, isto é, "o recato e a pureza, que aprisionam o ideal feminino branco, são abandonados pela violação explícita, a disponibilidade e o livro acesso atrelado aos corpos negros"326.

Ainda, outro caminho necessário que a criminologia crítica precisa considerar a partir das leituras do feminismo negro é o relativo às relações entre direito penal e os conflitos no seio doméstico ou entre companheiros e companheiras. As demandas contemporâneas em torno da criminalização do feminicídio, mas também de criação da Lei Maria da Penha, estiveram relacionadas a uma ideia de que "o pessoal é político", um dos principais lemas dos movimentos feministas de meados do século XX. Nesse sentido, ao Estado caberia a intervenção nesses conflitos por meio de serviços de assistência psicossocial, médica e também policial, este último aspecto bastante controverso entre as criminólogas feministas.

Porém, duas coisas precisam ser pontuadas: primeiramente, "o conceito de família patriarcal, como tem sido utilizado até agora, achata as diferenças, comprimindo-as até caberem num mesmo molde que é então utilizado como ponto de referência quando se fala de família no Brasil”327. Ele ignora que, em nosso país, muitas mulheres negras e pobres chefiavam suas famílias e eram praticamente as únicas provedoras da casa. O caso de Antônia, narrado acima, é bastante emblemático. Ela tem uma filha e, sozinha, a mantém. Precisou, para tanto, pagar por serviços ou contar com o apoio de sua irmã. Antônia não corresponde ao perfil da mulher subjugada à ordem familiar patriarcal e a polícia possuía total interesse em verificar o que se dava no interior de sua residência. Ao mesmo tempo, interferiu de tal forma em sua vida familiar, que tomou dela, possivelmente, a sua filha e a entregou a um juiz de órfãos para adoção, como ocorria com muitas prostitutas à época.

Por outro lado, os casos de defloramento, sobre os quais comentamos no capítulo 2, deixam evidente que a polícia possuía muita ingerência sobre a vida das famílias patriarcais negras e pobres, providenciando casamentos entre defloradores e defloradas, interferindo na forma como a honra dessas meninas seria ou não resguardada. Portanto, “o pessoal” já era assunto de polícia para muitas mulheres quando começamos a gritar que ele era "político" e precisava de Estado.

\footnotetext{
326 FLAUZINA, Ana Luiza Pinheiro. O feminicídio e os embates das trincheiras feministas. Discursos sediciosos: crime, direito e sociedade. Ano 20, números 23/24, p. 95-106, 2016, p. 100.

${ }^{327}$ CORREIA, Mariza. Repensando a família patriarcal brasileira. Cadernos de Pesquisa, São Paulo, n. 37, p. 516, mai, 1981, p. 10.
} 
Assim, a sessão da "Locação de Domésticos" e a sua busca incessante por garantir a higiene e a segurança da casa das mulheres brancas é, sem dúvidas, o retrato de uma sociedade que custou e custa em abandonar interações típicas de um sistema escravocrata, em que o corpo da escrava estava sob constante vigilância. A mucama ama-de-leite do século XIX, a empregada doméstica do século XX e as babás dos dias atuais estiveram e estão sendo observadas nos espaços públicos ou privados, através da polícia ou das câmaras de segurança instaladas no interior de nossas residências ou nossos edifícios. Não há, para elas, apenas, o controle social informal.

Feitas essas considerações, reiteramos a importância de abandonar a imagem de "sistehood" para pensar o controle policial sobre mulheres, porque estamos lidando com situações muito díspares. O caso da prostituição - talvez o contingente mais passível de sofrer prisões no período estudado - é bastante emblemático.

Em "Sobrados e Mucambos", Gilberto Freyre faz alusão a algumas obras do século XIX sobre prostituição, escritas, em sua maioria, por médicos. Grande parte dessa literatura se dedicava a pensar a higiene pública e o risco que contaminação de homens quando se relacionavam com essas mulheres. Porém, nem toda prostituição seria igualmente nefasta e a repugnante. Haveria três níveis delas: as aristocráticas ou de sobrados, as de sobradinhos e, finalmente, as de mucambos, casebres e malhoças. Noutro momento, as prostitutas de mucambo seriam descritas por Freyre como de "baixas condições" (libertas e escravas) ${ }^{328}$.

A distinção apontada por Freyre vai aparecer na atuação da polícia no início dos novecentos. Embora contrária a valores sociais caros à Primeira República, como os relativos à moralidade pública, ao casamento monogâmico, à virgindade feminina e à fidelidade, a prostituição não chegou a ser crime no Brasil. Se ela existia de qualquer forma, porque mesmo no discurso médico e policial da época, era vista como uma atividade necessária e fundamental para "canalizar os resíduos seminais masculinos"329, seria preciso regulamentá-la e mantê-la nos níveis da higiene social. À polícia, como principal instância de gestão do espaço público, seria dada essa tarefa.

Na tese VII da terceira seção da Conferência Judiciária-Policial, Celso Vieira de Mello Pereira também vai distinguir o alto e baixo meretrício, dispensando a cada um deles um diferente tratamento policial. No primeiro deles, praticado em Casas de Pensão luxuosas ou em Casas de Rendez-vous, caberia aos agentes policiais agir de forma mais "discreta e

\footnotetext{
${ }^{328}$ FREYRE, Gilberto. Sobrados e mucambos. São Paulo: Global, 2004, p. 416.

329 RAGO, Margareth. Os prazeres da noite: prostituição e códigos da sexualidade feminina em São Paulo (1890-1930). São Paulo: Paz e Terra, 2008, p. 133.
} 
moderada", pois são formas "não escandalosas, cujo interesse maior consiste, dada a situação dos hospedes e frequentadores, no disfarce da sua imoralidade" 330 .

Já em torno das chamadas Casas de passe ou habitações coletivas - os mucambos? - a polícia precisaria agir de maneira enérgica, porque "assim o exigem, sobrelevando a outros motivos de higiene e ordem, a promiscuidade que ai reina, a turbulência alcoolica e o desregramento de hábitos dos seus inquilinos e frequentadores, em geral de baixa classe e maus antecedentes" 331 , afinal, "semelhantes casas, muita vez, são abrigos de malfeitores, locais onde se verifica, sobretudo, a perversão das operárias, domésticas e menores indigentes ou abandonados" 332 .

São frequentes, entre os séculos XIX e XX, os regulamentos policiais acerca da atividade em exame. Eram chefes de polícia que se engajavam na luta pela eliminação ou, mais frequentemente, moralização dessa atividade. O Decreto n. 1034 A, de 1 de setembro de 1892, regulamentando a lei n. 76 de 1891, que organizava o Serviço Policial no Distrito Federal, passou a prever ser da atribuição do chefe de polícia "Art. 22, § 21. Ter sob sua severa vigilancia as mulheres de má vida, providenciando contra ellas, na fórma da lei, quando offenderem publicamente a moral e bons costumes".

Na Conferência Judiciária-Policial de 1917, esse tema foi, inclusive, pautado, conforme apontei no capítulo anterior.

Em São Paulo, Cândido Mota, chefe de polícia nos últimos anos do século XIX, organizou o primeiro Regulamento sobre a polícia de costumes, disciplinando modos e formas de exploração da prostituição. Ele próprio, autor do livro "Prostituição, polícia de costumes e lenocínio", entendia ser primordial a atividade ocorrer em regime de confinamento, evitando, assim, o escândalo. Como chefe de polícia, procurou normalizar, sobretudo, a atividade do baixo meretrício ${ }^{333}$.

No mesmo sentido, Oscar de Macedo Soares cita a regulamentação de um chefe de polícia do Distrito Federal, Bento de faria, que, em 1905, determina que toda mulher meretriz deve ser presa por vadiagem e, elogiando o policial, lamenta:

\footnotetext{
${ }^{330}$ PEREIRA, Celso Viera de Mello. Tese VII. Seção 3. Annaes da Conferência Judiciária-Policial. Rio de Janeiro: Imprensa Nacional, 1918, p. 488.

331 PEREIRA, Celso Viera de Mello. Tese VII. Seção 3. Annaes da Conferência Judiciária-Policial. Rio de Janeiro: Imprensa Nacional, 1918, p. 489.

332 PEREIRA, Celso Viera de Mello. Tese VII. Seção 3. Annaes da Conferência Judiciária-Policial. Rio de Janeiro: Imprensa Nacional, 1918, p. 499.

333 RAGO, Margareth. Os prazeres da noite: prostituição e códigos da sexualidade feminina em São Paulo (1890-1930). São Paulo: Paz e Terra, 2008, p. 134.
} 
Se todos os delegados providenciassem no mesmo sentido e, sobretudo, se as ordens fossem cumpridas meticulosamente pelos subalternos, em algumas ruas dessa cidade não se exhibiriam os quadros escandalosos que tanto ofendem à moral pública e aos bons costumes ${ }^{334}$.

No Recife, a polícia chegou a mapear as casas de prostituição. No livro de ofícios de delegados e subdelegados da $1^{\text {a }}$ Delegacia da Capital de 1926, consta uma lista com aqueles estabelecimentos e as ruas nas quais se localizavam, informando, ainda, a mulher responsável pelo local (anexo 11). Esses estabelecimentos, entretanto, não costumavam ser alvo de investidas policiais.

Preocupante eram as prostitutas chamadas de "escandalosas", "decaídas", de "trottoir", como referidas nos arquivos policiais consultados, que exerciam seus ofícios utilizando a rua como um espaço de recrutamento de clientes. Elas acabam por cair nas malhas do sistema penal como vagabundas, considerando que o tipo de vadiagem, Código Penal de 1890, era bastante amplo: "Deixar de exercitar profissão, officio, ou qualquer mister em que ganhe a vida, não possuindo meios de subsistencia e domicilio certo em que habite" ou "prover a subsistencia por meio de occupação prohibida por lei, ou manifestamente offensiva da moral e dos bons costumes".

Na tabela 6, observou-se que muitas mulheres eram recolhidas à CDR por ofensa à moral, certamente essas prostitutas "decaídas". Também eram frequentemente enquadradas como "vadias", podendo, neste caso, serem ou não prostitutas.

Em um ofício de 17 de dezembro de 1921, o delegado Liberalino de Almeida, da $1^{\text {a }}$ Delegacia de Polícia da Capital, expressou enorme preocupação com a atividade. Ele diz que apesar de todo o esforço que vem empreendendo contra a prostituição, tem recrudescido os atos das "decahidas" mulheres que praticam a "trottoir". Inconformado, escreve:

Ontem, tendo expedido um oficio aos subdelegados do meu distrito, recomendando a repressão aos gatunos e aos vadios, referi-me ao meretrício escandaloso, aos excessos das prostitutas de baixa estafa que atentam contra os bons constumes. O trottoir deve ser proibido, esse habito de estarem essas marafonas num ininterruptoo vai e vem que escandaliza.

Em 1918, o chefe de polícia Antonio Guimarães destacou a sua atuação também contra o meretrício escandaloso:

\footnotetext{
334 SOARES, Oscar Macedo. [1910] Código Penal da Republica dos Estados Unidos do Brasil commentado. Brasília: Senado Federal, Superior Tribunal de Justiça, Coleção História do Direito, vol. 6, 2004, p. 768.
} 
Sobre o meretrício e a indigência, também não tenho poupado esforços no sentido de restringi-los ao máximo possível, em benefício de nossos costumes. Até o ano de 1917, o meretrício exibia-se pelas ruas mais transitadas da cidade, afrontando a moral e privando as famílias de frequentarem essas ruas. Reconhecendo, em tempo, esse inconveniente que tendia a desmetir o nosso crédito de povo civilizado, resolvi agir, o que fiz imediatamente, conseguindo afastá-los das ruas onde passam os bondes ${ }^{335}$.

Ainda, em um ofício datado de 25 de agosto de 1917, o delegado do $1^{\circ}$ Distrito afirma que entende ser inconveniente a abertura do "Clube 15 de Novembro", por se situar em local de meretrizes. O teor do ofício do subdelegado é o seguinte:

Formando as vossas mãos a petição incluso, em que o sr. Francisco Correia de Souza, presidente do Centro Recreativo 15 de Novembro cito na rua dr. Feitosa, deste distrito, pede ao Exmo Desembargador Chefe de polícia para conceder permissão ao funcionamento do referido centro, tenho a informar que não acho regular o funcionamento do mesmo centro, visto que a sua sede é localizada em casa de meretrizes e assim naturalmente atrairá grande numero de pessoas que levados pelo álcool e influenciados pelo meio, é de presumir que o referido local torne-se enfector de desordens.

Assim, os regulamentos policiais visavam, sobretudo, a evitar a circulação de meretrizes nas ruas, pois o que verdadeiramente causava espécie era o "baixo meretrício". Essa distinção entre a prostituição de sobrado e de mucambo, presente - embora com outros termos e palavras - na atividade da polícia pernambucana, antepunha brancas e negras, policiáveis e não policiáveis e foi observada também por Margareth Rago em uma pesquisa realizada sobre a prostituição no início do século XX, na cidade de São Paulo. O "charme da francesa", como refere Margareth Rago, chegou a galvanizar a opinião pública, que as idolatrava e as temia. "Se o corpo da ex-escrava fora controlado e domesticado, a meretriz estrangeira é que ameaçava deter o controle sobre os instintos reprimidos de homens e mulheres inexperientes" ${ }^{336}$. Sedutoras e dominadoras, essas mulheres da vida ameaçavam o recato e a inocência da mulher do sobrado, mas, em pouco tempo, passaram a ditar moda. Perfumes, penteados, chapéus, em tudo a melindrosa femme fatale parecia influenciar os modos de vida da elite brasileira. Eram, portanto, apesar de tudo, admiráveis e símbolo de liberdade.

\footnotetext{
${ }^{335}$ APEJE, Fundo SSP, Caixa 2. Relatório da Chefia de Polícia, 1918.

336 RAGO, Margareth. Os prazeres da noite: prostituição e códigos da sexualidade feminina em São Paulo (1890-1930). São Paulo: Paz e Terra, 2008, p. 48.
} 
Evidentemente, houve reação a esse excesso de liberdade das mulheres brancas. "Investindo todas as suas energias no cultivo da própria imagem, no embelezamento do corpo em detrimento do espírito" ${ }^{337}$, essas mulheres seriam censuradas em muitas manifestações da imprensa porque agiam contrariamente aos valores da boa mãe e filha.

Mas, verificar que elas pudessem ser símbolo de beleza e estilo enquanto outras prostitutas eram o da sujeira e da desordem, reforça o argumento aqui construído. Mais uma vez, o trabalho de Naila Franklin é fundamental nessa leitura. Estudando a obra de Nina Rodrigues, Naila verifica que ele se ocupou bastante das mulheres, e as separava em diferentes categorias, sendo que a negra "era uma categoria caracterizada como más mães, prostitutas por natureza, detentoras de sexualidade desenfreada e devotas a uma religião profana".

Desse modo, se um dos principais nomes do positivismo criminológico brasileiro dedicou tantas páginas a essas mulheres é porque elas eram impregnadas de elementos de risco e perigo, assim como homens negros. De fato, ao se referir às mulatas, o médico maranhense não deixava de observar o caráter degenerador que elas tinham, porque passavam, através da mestiçagem, elementos da raça inferior. Naila cita a observação que ele faz de europeus que se casaram com mulatas e tiveram filhos que padeciam das mais diversas taras, concluindo, enfim, que, para ele: "As mulheres - mestiças ou negras - seriam as responsáveis pela tara hereditária que assolaria o país em sua formação, pois são elas que carregariam o elemento da raça inferior no país, fazendo diluir a raça branca no Brasil”338.

Enfim, o mucambo é a morada das mulheres de má vida, dos homens vagabundos e também dos operários, como mencionamos no início deste capítulo. Vamos nos ocupar, agora, desses últimos e da polícia política exercida no Recife.

\subsection{A POLÍCIA POLÍTICA}

Ministério das Relações Exteriores. Rio de Janeiro, 7 de fevereiro de 1919. Gabinete do Ministro. Confidencial. Senhor Ministro: A embaixada Americana acaba de me communicar haver recebido um telegrama da Legação Americana em Christiania, em que o adido militar dez que soube, por fonte absolutamente neutra, que alguns agentes russos bolshevick, pretendem, com passaportes falsos dinamarqueses, vir ao Brasil. A embaixada oferece-se, caso

\footnotetext{
337 RAGO, Margareth. Os prazeres da noite: prostituição e códigos da sexualidade feminina em São Paulo (1890-1930). São Paulo: Paz e Terra, 2008, p. 73.

338 FRANKLIN, Naila Ingrid Chaves. Raça, gênero e criminologia: Reflexões sobre o controle social das mulheres negras a partir da criminologia positivista de Nina Rodrigues. Dissertação de mestrado. Programa de Pós-Graduação em Direito. Universidade de Brasília, 2017, p. 166.
} 
julguemos necessário, a fazer mais detalhes para impedir que cheguem ao Brasil esses elementos perigosos para a nossa ordem pública ${ }^{339}$

Há um século, vivíamos em nosso país intensas lutas sociais que culminaram em episódios como a revolta da vacina, a revolta da chibata e a greve geral de 1917. Naquele momento, além dos conhecidos desordeiros do império e do início da República - vadios, ébrios, prostitutas, mendigos e loucos - o fantasma bolchevique assombrava as elites e o governo, aparecendo constantemente nos documentos policiais. A leitura do ofício acima descrito, encaminhado a diversos chefes de polícia em todo o Brasil, a mando do Ministro das Relações Exteriores, demonstra essa preocupação, que, por sua vez, não se limitaria à Polícia. O campo jurídico como um todo seria bastante provocado pelo desafio de conciliar liberdade e igualdade impostos pela República e as velhas e novas demandas por controle da insurgência, notadamente, agora, das associações operárias, tema presente na Conferência Judiciária-Policial.

Sem dúvidas, durante toda a Primeira República o clima foi de grande tensão. O novo regime não alterara as características da sociedade brasileira, marcada pela profunda desigualdade social e exclusão, da vida política, de parte considerável da sua população. Apenas a título de exemplo, em relação ao direito de voto, a constituição de 1891 excluiu as mulheres e os analfabetos. Estima-se que, à época, $80 \%$ da população masculina era de analfabetos. Somando-se estes às mulheres, pode-se concluir que a esmagadora maioria de nossos cidadãos estavam alijados do processo político institucional ${ }^{340}$. A descentralização política obtida pela adoção do federalismo estadunidense, por outro lado, fez surgir, nos estados, o poder de oligarquias que se mantiveram no governo à custa, muitas vezes, da efetiva intimidação do pouco eleitorado, da compra de votos e do "voto de cabresto".

Contrários a essa democracia formal incompleta, surgiram movimentos de resistência operários no final do século XIX e início do XX. No Recife, em 1890, foi criada a Liga Operária Pernambucana e, oito meses depois, foi registrada a primeira greve no Recife. Diversos outros movimentos grevistas ocorreram entre os últimos anos do século XIX e os

\footnotetext{
${ }^{339}$ Comunicado enviado ao Chefe de Polícia de Pernambuco pelo Chefe de Polícia do Distrito Federal, Antonio da Costa Araújo. APEJE. Fundo SSP, livro 1317. Ofícios da Chefia de Polícia de Pernambuco. 1919.

${ }^{340}$ CARVALHO, José Murilo de. Cidadania no Brasil: o longo caminho. Rio de Janeiro: Civilização Brasileira, 2015, p. 45.
} 
primeiros do século $\mathrm{XX}$, fatos estes que contavam com o protagonismo dos trabalhadores, patrões e da polícia ${ }^{341}$.

Em âmbito nacional, a década de 1910 teria protagonizado uma crise econômica geradora de desemprego e aumento da pauperização das classes populares. Embora houvesse uma grande dificuldade de organização da classe operária, “a Greve Geral de julho de 1917 em São Paulo abriria uma conjuntura histórica cujos limites se estendem cronologicamente até 1920,342 .

No relatório da Força Pública do Estado de Pernambuco de 1916 a 1920, apresentado ao Secretário Geral do Estado, Olintho Victor, pelo comandante da Força Pública, o Coronel José Novaes, em 1919, há referência a diversas greves "de quase todas as classes trabalhadoras em várias épocas no decorrer destes quatro últimos anos" ${ }^{343}$.

No mesmo período, os ofícios trocados entre chefes de polícia dos mais diversos estados, sobretudo com os do Distrito Federal e de São Paulo, demonstram uma preocupação crescente com a ameaça bolchevique, anarquista e do maximalismo ${ }^{344}$, além do risco inerente à própria atividade de organização operária. Os ofícios são encaminhados com os nomes, fotografias e identificação datiloscópica daqueles indivíduos considerados de máxima periculosidade por suas ideias subversivas, a exemplo do constante no anexo 12.

Enfim, o operariado brasileiro já se organizava desde o final do século XIX e o direito penal tratou de enquadrar suas atividades. O Código Penal de 1890, em sua primeira edição, criminalizou a greve ou a "parede", tipificando, no artigo 206 a conduta de "Causar, ou provocar, cessação ou suspensão de trabalho, para impor aos operarios ou patrões augmento ou diminuição de serviço ou salário". Pouco tempo após a publicação do Código, pressões de sociedades operárias provocaram alterações nessa redação, passando ela, após a edição do Decreto n. 1162, a prever como elementos do tipo o uso da ameaça e da violência. Assim, a greve em si deixava de ser crime.

Essa alteração dividiu a opinião de penalistas. Na Conferência Judiciário-Policial de 1917, essa mudança foi elogiada por Galdino Siqueira, tal qual antes mencionado, que argumentava possuírem os países civilizados e as nações cultas (notadamente a Inglaterra) legislações favoráveis à greve pacífica. A mudança foi mal vista, entretanto, por Oscar de

\footnotetext{
${ }^{341}$ MAIA, Clarissa Nunes. MAIA, Clarissa Nunes. Policiados: controle e disciplina das classes populares na cidade do Recife, 1865-1915. Tese de doutorado. Programa de Pós-Graduação em História da UFPE, 2001, p. 163.

${ }^{342}$ FAUSTO, Boris. Trabalho urbano e conflito social (1890-1920). São Paulo, Rio de Janeiro: DIFEL, 1976.

${ }^{343}$ NOVAES, José. Força Pública do Estado de Pernambuco - Relatório. Recife: Imprensa Oficial do Estado, 1919, p. 9.

${ }^{344}$ Como era referido o marxismo.
} 
Macedo Soares. Para ele, as nações civilizadas como a França, criminalizavam a greve ${ }^{345}$. Entendia que, assim como se dava naquele país, qualquer forma de coalização deveria ser punida, posto que a paralisação súbita do trabalho gerava prejuízos à vida econômica e era uma deslealdade do trabalhador com o seu patrão.

A Constituição de 1891, por seu turno, garantiu a liberdade de associação, no artigo $71, \S 8^{\circ}$. Porém, mesmo diante da permissão aos movimentos grevistas e à criação das associações sindicais, o Código Civil de 1916 determinava que o governo poderia dissolver tais organizações quando elas fossem nocivas ao bem público ${ }^{346}$. Nocivas eram, segundo Siqueira, aquelas que se dedicavam a fins políticos, posto que o Decreto 1637 de 1907, que permitiu a criação dessas associações, afirmava serem elas destinadas exclusivamente a interesses gerais da profissão e profissionais de seus membros ${ }^{347}$.

Boris Fausto ressalta que juristas liberais tendiam a defender essas organizações e suas atividades, a exemplo de Rui Barbosa, que, nas eleições presidenciais de 1919, apresentou um programa neste sentido, superando, assim, a avidez puramente repressora da polícia $^{348}$.

Sendo as associações e as greves permitidas pelo direito, eram toleradas pelas autoridades policiais. Porém, a participação dessas forças nos movimentos se dava de diversas formas: controle do conteúdo ideológico compartilhado nos espaços operários, acompanhamento por meio de agentes infiltrados nas atividades dessas organizações e, até mesmo, processos de mediação entre operários e empregadores facilitados por delegados ou subdelegados.

No que tange a esse último aspecto, no Relatório da Chefia de Polícia de 1818, Antonio Guimarães dedica duas páginas a falar sobre os movimentos grevistas do Estado e a demonstrar como atuou pela "pacificação" de uma situação vivenciada entre trabalhadores e patrões da Société de Cotonière Belge-Bresilienne.

A referida empresa passou a proibir, em seu interior, a cobrança, pela "União Operária”, de uma contribuição em pecúnia pelos trabalhadores. Inconformado, Alfredo

\footnotetext{
345 SOARES, Oscar Macedo. [1910] Código Penal da Republica dos Estados Unidos do Brasil commentado. Brasília: Senado Federal, Superior Tribunal de Justiça, Coleção História do Direito, vol. 6, 2004, p. 390-391.

346 O Código Civil de 1916 previa: Artigo 21. Termina a existência da pessoa jurídica: (...) III - pela sua dissolução em virtude de ato do Governo, cassando-lhe a autorização de funcionar, quando a pessoa jurídica incorra em atos opostos aos seus fins ou nocivos ao bem público.

347 SIQUEIRA, Galdino. These IX. Annaes da Conferência Judiciária-Policial de 1917. Rio de Janeiro: Imprensa Nacional, 1918, p. 318.

${ }^{348}$ Embora a repressão tenha sido a tônica do tratamento com a classe operária no período, houve vozes de contraposição a essa tendência, as quais buscavam legitimar o direito de associação e organização, assim como as reformas nas leis trabalhistas. Boris Fausto ressalta que Rui Barbosa, nas campanhas presidenciais de 1919, apresentou um programa neste sentido, superando, assim, a avidez puramente repressora. Ver: FAUSTO, Boris. Trabalho urbano e conflito social (1890-1920). São Paulo, Rio de Janeiro: DIFEL, 1976, p. 217-220.
} 
Rocha, sindicalizado e empregado daquele estabelecimento, teria mantido o recolhimento da referida contribuição e, por conta disso, acabou sendo demitido, fato que fez eclodir a "parede", no dia 18 de agosto. Foi então que o chefe de policia se dirigiu até o local e, pessoalmente, propôs uma conciliação entre as partes, o que, a princípio, deu certo. Porém, diante de outras insatisfações, a greve acabou sendo novamente deflagrada em 18 de setembro, afirmando a Chefia de Polícia que manteve um oficial cotidianamente no local, evitando erosão à ordem pública e buscando saídas pacificadoras.

A atitude conciliadora de Antônio Guimarães se repetiu em outros três episódios grevistas, protagonizados por operários da "Fábrica de Tecidos e Malhas da Várzea" e das fábricas de cigarro "Caxias" e "Lafaiette".

Para o chefe de polícia, essas greves não demandariam atenção da polícia se não fosse a imigração de "doutrinas subversivas, infiltradas criminosamente na massa operária", posto que o "operariado pernambucano é morigerado, trabalha e luta dentro da ordem visando o seu direito"349. Porém, a violência dos movimentos era explicada pela inserção das ideias anarquistas, razão pela qual defendia a permanente vigilância policial desses movimentos.

Na gestão de Eurico de Souza Leão, em 1927, o operariado pernambucano já não é descrito como tão ordeiro assim, registrando aquele chefe de polícia receio com essas atividades.

A polícia manteve, durante o ano findo, uma severa vigilância no tocante a manifestações operárias, procurando evitar que os homens do trabalho, mal insinuados, se demandassem em greves estéreis e contraproducentes. Ainda mais: a polícia está preparada para conjurar qualquer manifestação grevista, com o controle que tem de todas as associações operárias nesta capital ${ }^{350}$.

Ele ainda ressalta a preocupação com a ameaça comunista e a expansão do regime russo, o que justificaria a sua permanente vigilância. Ele descreve, então, a sua atuação:

\footnotetext{
Ameaça terrível às instituições, impondo, por isso, a todos os dirigentes uma severa e permanente vigilância, tem se constituído o movimento comunista que se implantou na Russia e procura irradiar-se por todo o mundo, infiltrando-se, de preferência, nas classes operárias. A polícia de Pernambuco conhece, perfeitamente, todas as associações operárias do Estado, as suas tendências, os seus chefes, a comunhão de ideias entre as congêneres e dispõe de elementos para assegurar incontestável controle sobre as suas atividades.
}

\footnotetext{
${ }^{349}$ APEJE, Fundo SSP, Caixa 2. Relatório da Chefia de Polícia, 1918.

${ }^{350}$ APEJE, Fundo Secretaria de Justiça, Livro 202, Relatório da Chefia de Polícia, 1928.
} 
Entretanto, em nosso estado, dos chefes de polícias aparentemente mais liberais aos mais reticentes a essas atividades, todos dedicavam páginas e páginas de seus relatórios a comprovarem que estavam constantemente monitoramento os movimentos operários ou anarquistas, além de conhecerem cada uma dessas associações, seus membros e sede de organização.

Como não poderia deixar de ser, pois era o padrão de atuação de uma polícia soberana, boa parte dessas atividades de monitoramento e repressão ficava a cargo das polícias sem maiores interferências do poder judiciário. Desse modo, assim como atuava tentando conciliar as partes envolvidas em greves ou paredes, a polícia também mantinha suas atividades de vigilância, espionagem e repressão a todo vapor e como julgasse conveniente.

Em ofício do Delegado da $1^{\mathrm{a}}$ Delegacia de Polícia da Capital, Manuel Andrade da Silva, ao Chefe de polícia de Pernambuco, no dia 11 de janeiro de 1920, ele nomeia as sociedades operárias naquele distrito:

Satisfazendo a circular de Vossa Excelência, datada de 2 do corrente, tenho a informar serem as seguintes as sociedades operárias existentes neste distrito: sociedade de metalúrgicos, União dos Estivadores, União dos Padeiros, União dos Carroceiros, Sociedade dos Garções etc.

Após cada um dos vários nomes apontados aparece o endereço onde elas se localizavam, para os quais a polícia seguia em dias de atos, protestos e reuniões.

É isso o que se pode deduzir de um incidente narrado pelo subdelegado de Santo Antônio, em 1917, à autoridade policial da $1^{\text {a }}$ Delegacia da Capital. O caso foi o seguinte: em 8 de setembro daquele ano, por ordem do "excelentíssimo senhor desembargador chefe de polícia", um soldado foi posto em frente ao vespertino "A luta". Porém, em dado momento, esse soldado teria sido vaiado pelos indivíduos que se encontravam na sede do jornal e, em decorrência disso, retirou-se de seu posto. O subdelegado de Santo Antonio, ao comunicar tal fato à Chefia de Polícia, concluiu que a "fraqueza" do soldado era injustificada e que, por essa razão, ele teria sido preso $^{351}$.

Independentemente do baixo ou alto profissionalismo do praça, fato é que a Chefia de Polícia entendia ser necessária a vigilância de um jornal de operários.

${ }^{351}$ APEJE, Fundo SSP, livro 458. Livro de Ofícios de Delegados e Subdelegados da $1^{\text {a }}$ Delegacia de Polícia. 1917. 
Outra das tarefas desempenhadas pela polícia nessa missão de conter a desordem dos movimentos trabalhistas era a prisão para averiguação, o que, como já mencionado, não era uma exclusividade da polícia política.

Em um ofício emitido pelo delegado da $1^{\text {a }}$ Delegacia de Polícia da Capital, Arnulpho Lins e Silva, em maio de 1919, ao Chefe de polícia de Pernambuco, são descritas as diligências que teriam sido desenvolvidas contra o operário de ideias maximalistas João Gomes. Os atos de investigação consistiram na tomada de depoimento de trabalhadores que dividiam o ambiente laboral com ele, na Alfaiataria Tic Tac. Em um desses depoimentos, o alfaiate José Ribemboim declarou:

que desde o primeiro dia do seu serviço que o depoente notou em João Gomes ideias maximalistas subversivas da ordem (...) que sabe perfeitamente que a polícia tomou medidas rigorosas contra João Gomes, não por ser o mesmo "caften" e sim por estar se tornando um perigo para a sociedade na propaganda de suas ideias maximalistas. (...) Que sabe haver o senhor Elias, alfaiate estabelecido na Rua do Imperador, defendido a João Gomes na Delegacia $^{352}$.

Dois aspectos fundamentais emergem dessa fala do alfaiate José. O primeiro deles é relativo ao cruzamento das ilegalidades morais, políticas e de classe. José Gomes, um subversivo político era, também, classificado pelas forças policiais como um subversivo sexual, explorador da prostituição, fato cuja veracidade não se conhece, mas que é característico dos processos de criminalização, tendentes a encontrar uma identidade desviante mais do que condutas desviantes. O outro ponto é que a polícia, quando precisasse eliminar um indivíduo perigoso, parecia não estar adstrita às hipóteses legais, posto que, segundo o alfaiate que prestou depoimento, ser "caften" teria sido uma espécie de "desculpa" para prender João Gomes.

O depoimento de José Ribemboim é confirmado por outro alfaiate, Passidrônio Cavalcanti. Foram ouvidos ainda pela polícia dois clientes da alfaiataria, que confirmaram que José Gomes era um "propagandista do socialismo russo e do maximalismo" e que, àquela altura a polícia já teria prendido João Gomes e o deportado de volta para Portugal, seu país de origem.

Em outro ofício, datado de 31 de Janeiro de 1920, encaminhado ao chefe de polícia de Pernambuco, Luis Corrêa de Oliveira, delegado da $1^{\text {a }}$ Delegacia de Polícia da Capital, Manuel

352 APEJE, Fundo SSP, livro 460. Livro de Ofícios de Delegados e Subdelegados da $1^{\text {a }}$ Delegacia de Polícia. 1919. 
Andrade da Silva, informa sobre um novo episódio de vigia das atividades dos trabalhadores organizados. O referido delegado afirmava que as sociedades operárias do Recife estariam comemorando a chegada, na cidade, de Eduardo Dias, líder dos trabalhadores que teria sido deportado pelo governo da República, mas, em seguida, recebido permissão para retornar ao país. Como o sr. Eduardo se tratava de um "elemento prejudicial à ordem e à paz do regimen", o delegado comunicava ao chefe de polícia que teria "tomado medidas acauteladoras da boa ordem e da segurança públicas ”. No documento, ele informava que:

Anunciadas manifestações festivas e até passeatas dos operários, fiquei, como era natural, de sobre aviso, procurando acompanhar de perto todo movimento. Às 12 horas, chegou-me às mãos um boletim anunciando um comício operário na Várzea. Comunicando-me com o Dr. Delegado do $2^{\circ}$ Districto, a que pertence aquele subúrbio, fui informado de que as providências já haviam sido tomadas. Desconfiando de que o boletim que anunciava a reunião na Várzea tinha só o fim de distrair a acção da policia, dirigi-me às 15 horas à Rua Pedro Affonso, onde está a sede de diversas associações de operárias, no $1^{\circ}$ e $2^{\circ}$ andar do prédio que faz esquina para a Taverna do Carioca. Ali chegado soube que já havia discursado o Dr. Joaquim Pimenta. Discursava no momento o Dr. Capistriano Cordeiro, cujo discurso ia terminar. Ouvido pela assistência numerosa em profundo silêncio, dizia o orador sentir-se comovido e emocionado de tal (ilegível) ante o espetáculo que assistia que era com dificuldade que pronunciava palavras, frases e períodos. A satisfação, que experimentava ante a vitória, a extraordinária vitória (palavras dele) do operariado no caso Eduardo Dias.

O delegado segue descrevendo o discurso do Sr. Capistriano Cordeiro e de outros operários que discursaram "quase todos em linguagem de baixo calão, atacando sempre e desordeiradamente aos poderes constituídos e as classes conservadoras". Por fim, afirma que os operários saíram em passeata ao final do comício ${ }^{353}$.

Também em 8 de julho de 1926, há um ofício encaminhado à Chefia de Polícia pelo delegado Affonso Baptista asseverando que, a respeito de informações pedidas pelo juiz da $2^{\mathrm{a}}$ circunscrição criminal, os pacientes Aureo Luis, Antonio de Barros Lins e Jose Antonio da Silva tinham sido "detidos para averiguações policiais por serem encontrados em poder dos mesmos jornais revolucionários, tendo sido postos em liberdade após haverem prestado os necessários esclarecimentos a respeito" ${ }^{354}$.

${ }^{353}$ APEJE, Fundo SSP, $1^{\text {a }}$ Delegacia de Polícia. 1920. Livro 461.

${ }^{354}$ APEJE, Fundo SSP, livro 467. Relatórios de delegados e subdelegados de polícia, $1^{\text {a }}$ Delegacia da Capital, 1926. 
Esta última situação sinaliza para algo que não chegamos a verificar nesta pesquisa, que eram os habeas corpus interpostos no período. Eles podiam representar uma via, através do judiciário, de tentativa de contenção desse poder quase absoluto que a polícia mantinha em suas tarefas. Porém, apareceram tão raramente ofícios de delegados e subdelegados prestando informações a juízes que, suponho, não fosse uma estratégia usada pela imensa maioria da clientela policial.

Finalmente, já em fevereiro de 1927, um conflito entre o subdelegado de Santo Antonio e o delegado da $1^{a}$ Delegacia da Capital evidencia a persistência dessa prática de monitoramento e vigilância das atividades operárias. José Alves de Araújo, o subdelegado, reclama da atitude de seu superior, que por ocasião das greves da Firma Boxwell e Cia, estaria monitorando sozinho os trabalhadores, sem a sua ajuda ${ }^{355}$.

Procuramos, neste capítulo, ao tratar das estatísticas e narrativas policiais, entender um pouco quem eram os seus alvos. Pretos, pobres e operários, homens, mulheres ou crianças, a soberania policial se exercia sobre uma parcela muito delimitada da sociedade. São as figuras tipicamente descritas na criminologia positivista e também, socialmente falando, o que Michel Misse chamou de "sujeitos criminais", um conceito muito útil, na medida em que atenta para a força que a imagem do indivíduo tem nos processos de incriminação.

Ao procurar analisar o processo de acusação social, Michel Misse se utiliza de quatro conceitos que não obedecem, propriamente, aos conceitos jurídicos de criminalização. A primeira etapa constitui a criminalização "através da qual um determinado curso de ação passa a ser considerado crime, após uma campanha pública vitoriosa ou como resultado da tradição" ${ }^{356}$. O conceito aqui corresponderia ao de criminalização primária, em que condutas passam a ser consideradas delituosas e se inscrevem em um tipo penal.

Porém, certos eventos podem ser considerados como crimes, independentemente de estarem ou não coerentes com um tipo penal, e essa conduta passa a ser chamada de criminação. Misse continua:

Uma vez que haja "criminação" de um evento, isto é, que este evento seja interpretado como "crime", então se passa - sem intervalo que não seja analítico - para a "incriminação", isto é, para a nomeação de sua autoria, para a busca e punição de seu sujeito causal ${ }^{357}$.

\footnotetext{
355 APEJE, Fundo SSP, livro 469. Livro de Ofícios de Delegados e Subdelegados da $1^{\text {a }}$ Delegacia de Polícia. 1927.

${ }^{356}$ MISSE, Michel. Sobre a Construção Social do Crime no Brasil: Esboços de uma Interpretação. MISSE, Michel (org). Acusados e Acusadores: Estudos sobre ofensas, acusações e incriminações. 2008, p. 379.

357 MISSE, Michel. Sobre a Construção Social do Crime no Brasil: Esboços de uma Interpretação. MISSE, Michel (org). Acusados e Acusadores: Estudos sobre ofensas, acusações e incriminações. 2008, p. 380.
} 
A incriminação, entretanto, como atividade social de acusação pode ou não estar relacionada à existência de um fato praticado pela pessoa. Por vezes, a incriminação se antecipa à criminação e à criminalização e alguns sujeitos passam a se identificar com o crime mesmo sem cometê-lo. Suas imagens correspondem à do criminoso.

A sujeição criminal é, portanto, um procedimento de nomeação de um tipo social negativo; "refere-se ao processo social pelo qual se dissemina uma expectativa negativa sobre indivíduos ou grupos, fazendo-os crer que essa expectativa não só é verdadeira como constitui parte integrante de sua subjetividade" ${ }^{358}$. Esse processo não é exclusivo da polícia ou dos saberes criminológicos, e, ao contrário, é reproduzido no âmbito das interações sociais. Portanto, a soberania policial se exerce sobre sujeitos a quem o senso comum também nomeia como criminoso, o que, evidentemente, ajuda a legitimá-la.

Delimitados os alvos, afinal, como atuava a polícia? Quais eram seus métodos? O que era feito a esses malfeitores e desordeiros? Essa resposta merece uma reflexão mais detalhada, porque aqui está-se diante de uma realidade atravessada por discursos e práticas que, por vezes, caminham em sentido oposto.

\footnotetext{
${ }^{358}$ MISSE, Michel. Sujeição Criminal. In: LIMA, Renato Sérgio de; RATTON, José Luiz; AZEVEDO, Rodrigo Ghiringhelli de. Crime, polícia e Justiça no Brasil. São Paulo: Editora Contexto, 2014, P. 204.
} 


\section{SOBERANIA POLICIAL E A UTOPIA DISCIPLINAR}

Até aqui, procurei demonstrar que as polícias civil e militar gastavam uma parte importante de seu tempo lidando com o que se pode chamar de "ilegalismos populares". O termo é de Michel Foucault e o uso para introduzir um ponto que acredito ser fundamental para compreender os meandros da soberania policial e que constitui o objeto deste capítulo.

Para Foucault, o capitalismo industrial teria reestruturado a economia das ilegalidades. A divisão de classes e a dicotomia proprietários versus não proprietários dinamizou as formas de criminalidade, tendo os primeiros - burgueses e donos dos meios de produção - se voltado mais à prática de "ilegalismos de direito" (fraudes, evasões fiscais, corrupção etc) e os segundos, tornando-se mais vulneráveis aos "ilegalismos de bens" (furtos, roubos e outras formas de ataque à propriedade).

Consequentemente a essa especialização, a justiça também se modificava, reservando às "ilegalidades de direitos" as sanções administrativas e cíveis e às de bens, àquelas de natureza penal. $\mathrm{O}$ nível de tolerância às infrações promovidas por cada um desses grupos seria, portanto, diferenciado. Como lembra o próprio Foucault, "um sistema penal deve ser concebido como um instrumento para gerir diferencialmente as ilegalidades, não para suprimi-las todas" 359 .

A gestão diferenciada dos ilegalismos é uma das grandes teses contidas em "Vigiar e Punir" e, em certa medida, comunica-se com outras importantes teorias com as quais a criminologia crítica lidou e lida a exemplo do labeling approach ou a Teoria do Etiquetamento e a sua leitura não essencialista do delito. Howard Becker, um dos principais representantes desta escola, em Outsiders, vai afirmar categoricamente que a criminalização não é uma tarefa natural, mas um processo de escolhas porque o delito não constitui um mal em si. Há quem defina certas condutas como negativas ou positivas, desviantes ou não desviantes.

É relevante lembrar que o desvio não se confunde com lei penal e tampouco com a lei. O desviante é todo aquele que inova na adoção de papeis sociais, assumindo identidades e modos de vida não esperados e não hegemônicos. O sujeito que pratica um homicídio e o músico noturno da casa de jazz, por exemplo, em determinados contextos culturais, poderiam ser considerados desviantes. Mas, afinal, quem pode definir o desvio? Para Becker, essa é a tarefa dos "empreendedores morais", pessoas localizadas em determinados grupos ou

${ }^{359}$ FOUCAULT, Michel. Vigiar e punir. $35^{\mathrm{a}}$ ed. Rio de Janeiro: Vozes, 2008, p. 75. 
identificados a certos padrões culturais que obtêm êxito em suas "cruzadas morais". As motivações dos empreendedores morais podem ter as mais variadas origens, mas, de regra,

as cruzadas morais são em geral dominadas por aqueles situados nos níveis superiores da estrutura social - significa que eles acrescentam ao poder que extraem da legitimidade de sua posição moral o poder que extraem de sua posição superior na sociedade ${ }^{360}$.

No campo criminal, por exemplo, os empreendedores morais devem alcançar o poder legislativo, participando dele diretamente ou sobre ele exercendo influência. Criar tipos penais e as penas a eles cominadas é o primeiro passo desse empreendimento, chamado de criminalização primária. Processar e julgar com base nessas leis já é tarefa de outros empreendedores, aqueles que investem nas agências policiais, acusatórias e judiciais, participando da chamada "criminalização secundária".

Embora Becker reconheça que os indivíduos situados em estratos sociais superiores possuem maiores chances de se tornarem empreendedores morais, de ditar o padrão de comportamentos toleráveis e intoleráveis, ele se furta a fazer leituras funcionalistas que relacionem essas escolhas a necessidades do sistema econômico ou de coesão social.

Foucault, ao contrário, ao concluir que a construção de categorias jurídicas permite a qualificação ou a desqualificação de certos comportamentos como ameaçadores, associa esse processo às necessidades do capitalismo industrial em ascensão no século XIX e, portanto, a uma questão de "dominação social" 361 . Não se trata simplesmente de dizer que o sistema punitivo é seletivo e pune apenas determinadas pessoas e condutas, conclusões a que chega a criminologia crítica, por exemplo, a partir da leitura da teoria do etiquetamento. A gestão diferenciada dos ilegalismos é mais do que a simples seletividade, pois aponta para outros mecanismos de relacionamento entre o sistema penal e a criminalidade, como os de favorecimento, de fortalecimento de determinadas formas de crimes e mesmo de ganhos com as atividades ilícitas ${ }^{362}$.

Além disso, essa gestão diferenciada obedece, na modernidade, a uma necessidade do capital $^{363}$. Definir e tratar certos comportamentos como criminosos e, portanto, certos

\footnotetext{
${ }^{360}$ BECKER, Howard. Outsiders. Rio de Janeiro: Jorge Zahar Editor, 2008, p. 155.

${ }^{361}$ LASCOUMES, Pierre. L'illégalisme, outil d'analyse. Société \& Représentations, nov, p. 78-84, 1996, p. 82.

${ }^{362}$ Foucault não aprofundará muito esse argumento em Vigiar e Punir. Entretanto, quando, no fim do livro, aborda o conceito de delinquência útil, acena para o fato de a proibição de certas condutas gerarem um campo de práticas ilegais dos quais se tira lucro ilícito, como no caso da proibição de álcool, da prostituição e de drogas. FOUCAULT, Michel. Vigiar e Punir. 35 ed. Rio de Janeiro: Vozes, 2008, p. 232.

${ }^{363}$ Para François Ewald, Foucault não faz uma leitura do tipo marxiana, na medida em que ao invés de afirmar ser o sistema punitivo derivado do capital, ele teria explicitado como uma anatomia política - a disciplina - teria
} 
indivíduos como perigosos é uma forma de permitir sobre eles a vigilância e a repressão qualificada normalizadora ou curativa; diferenciar a ilegalidade da burguesia e da classe trabalhadora é construir sobre eles diferentes aparatos, reservando a estes últimos os mecanismos de controle e disciplina. Em suma, prender os vadios, as prostitutas ou os ébrios, como mostrado acima, seria o primeiro passo de um longo caminho para discipliná-los e torná-los mão de obra útil e dócil para atuar no mercado de trabalho.

Foucault chega a essas conclusões analisando discursos penais, médicos e criminológicos do século XIX, além das reformas penais ocorridas no período. O cenário por ele descrito se assemelha, parcialmente, ao que vi na pesquisa sobre as práticas policiais no Recife.

Inicialmente, neste capítulo, vou me debruçar sobre os discursos criminológicos (mormente do campo jurídico e policial) acerca do criminoso e do tratamento que a ele deveria ser dispensado. Ficará evidente a crença, no período, na prisão e no encarceramento como medidas corretivas e necessárias no combate ao crime. Porém, aqui também será o espaço para demarcar o descompasso entre o discurso correcionalista e a prática punitiva e me perguntar os porquês. Sendo um pouco mais precisa, poderia indagar: por que, no Brasil, não efetivamos um projeto disciplinar no âmbito político-criminal?

Essa pergunta poderia ser o ponto de partida de outra pesquisa, porque, certamente, não é fácil de ser respondida e apresenta muitos meandros. Porém, estou convencida de que a soberania policial é um elemento fundamental a ser abordado em qualquer caminho interpretativo.

Uma polícia acostumada a ser soberana nas ruas, a dar seu tom na forma de agir, sem grandes intervenções de outras instâncias de controle, não combina com o projeto disciplinar, que, necessariamente, interliga polícia, judiciário e sistema carcerário, dividindo o poder entre todas essas searas, em um procedimento que, além de tudo, é bastante custoso.

Quando se pensa no esquema disciplinar foucaultiano, por exemplo, verificamos um remodelamento das instâncias punitivas, pondo em conexão policiais, juízes, médicos psiquiatras e agentes penitenciários. Afinal, um sujeito preso é posteriormente processado e julgado, para, enfim, cumprir uma pena reeducadora. Paralelamente a tudo isso, são realizados exames (uma investigação dos costumes, da família, dos hábitos, do meio social dos

sido um recurso explorado pelo sistema capitalista. Desse modo, "a nossa sociedade não é disciplinar porque capitalista, mas pelo fato de ser disciplinar é que o capital sabe dela tirar proveito". EWALD, François. Foucault, a norma e o direito. 2 ed. Lisboa: Vega, 2000, p. 38. 
indivíduos) que são ao mesmo tempo a condição para a interferência corretiva e a fonte do saber criminológico que, por sua vez, dita a atuação daquele sistema punitivo.

Ora, o dia a dia da polícia recifense era bastante intenso e permeado de prisões de muitos indivíduos e, nem que quisesse, a justiça daria conta de tudo isso. Deixar a polícia agir para conter a desordem pública acabava por ser conveniente e, deliberadamente ou não, uma parte das ilegalidades seriam erguidas ao nível do poder judiciário e todo o seu aparato de garantias e procedimentos - ao menos em nível formal - e outra parte, basicamente as contravenções, seria resolvida ali onde ninguém interfere, no espaço da soberania policial. No início do século XX, era a dicotomia entre crime e contravenção que informava essa distinção.

É como se tivéssemos dois grandes sistemas penais em funcionamento concomitante: um essencialmente policial e outro essencialmente judicial; um é o das contravenções e o outro, dos crimes; um que se desenvolve nas ruas e corredores de delegacia e outro que se passa em corredores de fórum. Não quero com isso dizer que, no sistema policial funcionava o "chute na porta" e nada mais; muito menos que no sistema judicial funcionava a aplicação lisa da lei e suas ideias correcionalistas. Não. O projeto disciplinar no Brasil foi ao longo de todo o século XIX e assim se manteve no século XX como um "panóptico impossível”, como o denominou Andrei Koerner.

Porém, um desses sistemas é ainda menos comprometido com o arsenal de garantias liberais, porque se expõe pouco a controles formais e informais e ocorre em um espaço da não cidadania, basicamente direcionado a não-cidadãos. Neste ponto, é fundamental compreender que a soberania policial é costurada, no Brasil, pelo racismo. Como destaca Luciano Góes:

os métodos de controle racial ordenados por um direito penal de viés doméstico ultrapassaram os limites fazendários seguindo os passos dos exescravos (tática dos capitães do mato), impondo uma cisão no Direito penal brasileiro: ao lado do Direito penal declarado para os cidadãos, o direito penal paralelo para os "sub-cidadãos", um sistema outrora identificado por Lola Aniyar de Castro como "subterrâneo" que no Brasil jamais se ocultou, sendo operacionalizado sob os olhos de quem quiser enxergar ${ }^{364}$.

Desse modo, o espaço e o modo da soberania policial permite entender o hiato a que me referi anteriormente: aquele estabelecido entre uma política criminal reformadora do indivíduo - intervenção sobre a alma - e o de uma prática das prisões de curta duração, do

${ }^{364}$ GÓES, Luciano. A "tradução" de Lombroso na obra de Nina Rodrigues. Rio de Janeiro: Revan, 2016, p. 169. 
arbítrio policial, dos acordos, das negociações e da violência -intervenção sobre os corpos. Nos próximos tópicos vou explorar esse hiato, mas, antes, refletir sobre a recepção da criminologia positivista no Brasil, mormente no campo policial.

\subsection{O IDEAL CORRECIONALISTA E A CRIMINOLOGIA POSITIVISTA}

A elite intelectual da América Latina foi uma grande leitora das criminologias positivistas europeias na virada para o século XX. Representantes da Escola Italiana, como Cesare Lombroso, Enrico Ferri e Rafaelle Garofalo e da Escola Francesa, como Gabriel Tarde e Alexandre Lacassagne são constantemente citados e referenciados nas obras de brasileiros, argentinos e outros latino-americanos que se propuseram a pensar o problema criminal no continente.

Rosa Del Olmo em “A América Latina e sua Criminologia” procurou entender os meandros desse processo de recepção. Para a autora, a nossa região, dependente socioeconomicamente do capitalismo central, não criou um saber criminológico ligado a sua realidade social, cultural e econômica. Ao contrário, importou-o dos centros de produção da criminologia tradicional, sobretudo a Europa, no final do século XIX e início do século XX.

A participação de penalistas, médicos legistas e outros intelectuais latino-americanos nos congressos, seminários e encontros internacionais das ciências criminais na Europa foi um importante mecanismo para garantir essa importação. O resultado seriam diversos documentos produzidos, traduções, adaptação de currículos em nossas Universidades, adoção de obras desses autores europeus, além da implementação de estratégias político-criminais, como os gabinetes de identificação, os institutos de criminologia e as reformas penitenciárias $^{365}$.

O campo penitenciário talvez tenha sido o mais fértil na incorporação dessas propostas. O discurso de gestores, políticos, juristas, médicos e policiais, na América Latina como um todo, no período, era majoritariamente correcionalista, isto é, o cárcere e outras unidades de internação como escolas correcionais para menores, para mendigos ou para loucos eram vistos como espaços de reparação da alma e de disciplina.

Máximo Sozzo lembra a reação de regozijo da filha de Lombroso, Gina Lombroso, quando, em 1907, visitou a Penitenciária Nacional de Buenos Aires e verificou que, ali, os ensinamentos de seu pai eram mais respeitados do que em qualquer unidade para presos na Itália. Gina, ao descrever a visita, aplaude a iniciativa dos argentinos de criar não uma

${ }^{365}$ DEL OLMO, Rosa. A América Latina e sua criminologia. Rio de Janeiro: Revan, 2004, p. 182-194. 
penitenciária, "mas uma casa de redenção, física e psíquica, intelectual e moral, tal e qual a nova escola a concebeu"366.

Porém, Sozzo também adverte que "toda tradução possui um componente criativo, interpretativo"367 e não constitui uma mera translação. Na América Latina, as produções intelectuais tinham verdadeira pretensão de intervenção na realidade e, portanto, precisariam se adaptar a ela e entender nossas particularidades. Assim é que, por exemplo, na Argentina, a tradução da criminologia positivista coloca o problema do imigrante em primeiro lugar, ao passo que, no Brasil, a leitura será fortemente racializada, apontando para a questão do negro, da mestiçagem e da degeneração como fatores criminógenos ${ }^{368}$.

De fato, no Brasil, quando se faz um apanhado do saber criminológico da virada do século XIX para o XX, verificamos forte apelo ao tema das raças e suas diferenças, elemento essencial para compreender os meandros do controle penal no Brasil, como vim pontuando ao longo de todo o texto.

Lilia Schwarcz explorou o pensamento científico do período e a incorporação de noções racialistas entre historiadores, geógrafos, juristas e médicos. No caso dos juristas, dedicou-se especificamente aos da Faculdade de Direito do Recife e aos da Faculdade do Largo do São Francisco. A autora não se debruçou sobre o pensamento policial, porém, o fato de os chefes de polícia serem formados necessariamente em direito e, muitos deles, nessas duas faculdades, torna imprescindível o olhar sobre o que se dizia ali.

Na Faculdade de Direito do Recife, a partir da leitura de artigos da Revista Acadêmica, Schwarcz observou uma incorporação até a década de 1920, do evolucionismo darwinista, e, portanto, do problema nacional como uma questão relacionada à mestiçagem ${ }^{369}$.

Naquela faculdade, nomes importantes da criminologia positivista racialista foram professores e estudantes, merecendo destaque os de Clovis Bevilaqua e de João Vieira de Araújo, ambos, de alguma forma, tendentes a aceitar a tese da inferioridade dos negros, ainda que ponderando de modo diferente a questão da miscigenação e da influência da raça sobre o problema criminal.

Os dois foram, também, os que mais contribuíram com a Revista Acadêmica no campo criminal, embora Bevilaqua tenha grande participação no campo cível e no da filosofia e da teoria do direito. No anexo 13, há a lista de todos os artigos relacionados de ciências

\footnotetext{
${ }^{366}$ Apud SOZZO, Maximo. Viagens culturais e a questão criminal. Rio de Janeiro: Revan. 2014, p. 36.

${ }^{367}$ SOZZO, Maximo. Viagens culturais e a questão criminal. Rio de Janeiro: Revan. 2014, p. 43.

${ }^{368}$ SOZZO, Maximo. Viagens culturais e a questão criminal. Rio de Janeiro: Revan. 2014, p. 49.

${ }^{369}$ SCHWARCZ, Lilia M. O espetáculo das raças: cientistas, instituições e questão racial no Brasil. São Paulo: Companhia das Letras, 1993, 196 e 218.
} 
criminais publicados na Revista Acadêmica da FDR entre 1891 a 1897 e 1908 a 1930. Nos primeiros anos da revista são mais frequentes trabalhos abordando a raça como principal fator de criminalidade.

Exemplo disso é o texto de Adelino Filho, "A Nova Escola de Direito Criminal", publicado em 1891. No artigo, ele afirma categoricamente, no esteio do pensamento também expresso por Bevilaqua, que "A ação delictuosa do verdadeiro criminoso tem seu incitador, morbido, pode ser, na constituição propria de seu ser" e, em relação aos criminosos, assevera que "A contextura moral de taes individuos nao tem a delicadeza sufficiente para vibrar a voz do preceito moral: sao, pois, homens inferiores aos seus contemporaneos". Por fim, finaliza citando Garofalo e afirmando que "cada raça possui instintos morais inatos, que nao sao, portanto, fruto do raciocínio individual, mas constitutitvo do tipo racial" 370 .

Essas versões muito ligadas às determinações biológicas e físicas serão, aos poucos, substituídas por debates sobre o meio social como um fator de risco para a criminalidade, apropriando-se os juristas de questões como a higiene, a saúde e a educação ${ }^{371}$, o que, como já disse. Lombroso e seu excesso de biologicismo parece ser preterido em relação a Enrico Ferri, para quem o meio social, aliado também a fatores biológicos, é causa para o crime, associando problemas como alcoolismo, jogos e prostituição ao crime ${ }^{372}$.

Em 1914, Laurindo Leão, no artigo intitulado "A questão do crime, conceito e caracteres, de sua justificação, de suas variações e de sua naturalidade, evolução e factores", trabalha algumas críticas às redutoras conclusões de Lombroso, Ferri e Garolafo e desataca a importância do meio no fenômeno criminal, ganhado destaque a própria cidade:

O aumento da criminalidade atual é devido antes de tudo ano enorme desenvolvimento das cidades, despovoando os campos e atraindo as energias para o mal como para o bem; a população urbana transbordou e formou um proletariado que vive entregue à todas as flutuações econômicas e fornecendo à vagabundagem e à criminalidade um terreno propício ${ }^{373}$.

\footnotetext{
370 FREIRE FILHO, Adelino de A. de Luna. A Nova Escola de Direito Criminal. Revista Acadêmica da Faculdade de Direito do Recife. Ano 1, volume 1, p. 27-35, 1891, p. 29-30.

${ }^{371}$ SCHWARCZ, Lilia M. O espetáculo das raças: cientistas, instituições e questão racial no Brasil. São Paulo: Companhia das Letras, 1993, p. 218.

${ }^{372}$ Ferri entende que "constitui, portanto, uma grande e incontrastável superioridade da escola criminal positiva sobre a tendência clássica e penitenciária, ter identificado que pena e delito se desenvolvem em duas esferas excêntricas, que a repressão, ainda quando correcional, não é bastante para evitar os delitos e as reincidências, e que existe uma teoria, a dos substitutivos penais que afirma a necessidade de uma higiene social sob a forma de prevenção remota. FERRI, Enrico. [1910] Estudios de antropologia criminal. 3 ed. Madrid: La España Moderna, Colección de libros escogidos, p 32.

${ }^{373}$ LEÃO, Laurindo. A questão do crime, conceito e caracteres, de sua justificação, de suas variações e de sua naturalidade, evolução e factores. Revista Acadêmica da Faculdade de Direito do Recife. Ano 22, volume 22, p. 19-96, 1914, p. 84.
} 
Em 1920, Octavio Tavares, ao fazer um apanhado da estrutura penitenciária do Brasil, revela um estado de absoluta podridão, ausência de trabalho e disciplina e incapacidade para qualquer finalidade reformadora do indivíduo. Sem trazer à tona muitas contribuições, mas uma espécie de estado da arte, Tavares conclui afirmando que é preciso pensar reformas penitenciárias não como cópias de modelos externos, mas adequadas às "condições económicas, de raça, de educação, de costumes etc"374 de nosso país.

Marcos Cezar Alvarez explorou também o pensamento de outros juristas no período. Para ele, três importantes nomes representariam bem a tendência teórica e ideológica da Nova Escola Penal: Francisco Viveiros de Castro, Paulo Eugídio e Cândido da Mota.

Francisco Viveiros de Castro, maranhense formado na FDR, foi crítico às noções do livre arbítrio e favorável a reformas das instituições penais, adotando a concepção de uma pena individualizada e voltada à periculosidade do criminoso. Paulo Egídio, leitor de Durkheim, mas defensor assíduo de Lombroso, de Ferri e de Garofalo, propõe, como Viveiros de Castro, modificações na legislação penal e unidades penitenciárias, pretendendo torna-las aptas à educação moral e cívica do preso, ensinando-lhe, ainda, um ofício ${ }^{375}$. Já Cândido Mota, que fez carreira na polícia de São Paulo, via na prostituição, na vadiagem e na mendicidade as principais causas do crime, havendo ainda outros fatores de risco como o clima, a raça e demais predisposições individuais ${ }^{376}$.

Para além do mundo jurídico, um dos desdobramentos da inserção de todos esses pensamentos foi a criação dos institutos de identificação, médico e criminológico. No capítulo 2, explorei um pouco o deslumbre da polícia em relação a essas inovações científicas e a força que tiveram nos discursos sobre modernização da organização. Por outro lado, as perícias e exames médicos davam à justiça um elemento de cientificidade e neutralidade ideal às suas pretensões de verdade. Por isso, obras como a de Nina Rodrigues têm merecido a atenção daqueles que estudam as relações raciais e o sistema punitivo, já que ele abordou a questão criminal e atuava frequentemente como perito em processos.

Nina Rodrigues era filho de donos de escravos, membro da elite baiana e estudou na Faculdade de Medicina da Bahia. No Brasil, foi reconhecido como um dos principais tradutores dos autores da Escola Positivista Italiana, dedicando boa parte de sua obra a

\footnotetext{
374 TAVARES, Octavio. O problema penitenciário entre nós. Revista Acadêmica da Faculdade de Direito do Recife. Ano 28, volume 28, p. 31-45, 1920, p. 45.

375 ALVAREZ, Marcos César. Bachareis, criminologistas e juristas: saber jurídico e Nova Escola Penal no Brasil. São Paulo: IBCCRIM, 2003, p. 101

${ }^{376}$ ALVAREZ, Marcos César. Bachareis, criminologistas e juristas: saber jurídico e Nova Escola Penal no Brasil. São Paulo: IBCCRIM, 2003, p. 108.
} 
entender a desigualdade entre brancos e negros, cujo reconhecimento, achava, deveria reverberar na construção do sistema punitivo, tanto em seus discursos como em suas práticas. Afinal, seria preciso continuar a tratar "os desiguais desigualmente, considerando assim, que os negros teriam direito a uma responsabilidade moral diversa por sua desigualdade biosociológica" 377 .

Curiosamente, Nina Rodrigues chegou a apoiar a existência de diferentes Códigos Penais no Brasil, cada um voltado a um estágio de evolução das raças. Nessa toada, chegou até mesmo a defender a existência de magistrados específicos para lidar com negros, os quais seriam auxiliados por médicos peritos ${ }^{378}$, responsáveis pelo “exame", no sentido foucaultiano do termo, isto é, pelo raio $x$ do indivíduo.

A noção de mais de um código, de mais de um tipo de direito penal, de políticas criminais diferenciadas para cada raça, típicas do positivismo criminológico, é a materialização de concepções que se antepõem à igualdade jurídica. Na prática, essa distinção acaba por ser real quando se verifica a existência daquela jurisdição policial para alguns casos e da intervenção efetivamente judicial em outros. A utopia de Rodrigues ganha corpo nas práticas policiais...

Enfim, o pensamento criminológico brasileiro do período, como se vê, não é homogêneo. Entretanto, há traços comuns entre os autores. Primeiramente, a abordagem da questão racial - vista como um vício em si ou como um vício do meio em que negros viviam , que conduz a uma conclusão: os homens são desiguais. Esta condição se expressaria na necessidade de garantir uma individualização da pena, pois esta não seria a medida da gravidade do crime, mas a da necessidade de tratamento do condenado. Como dizia João Vieira de Araújo, "à antiga concepção que quer que todo delito mereça um castigo correspondente, se opõe a ideia de que todo o culpado deve ser objeto d'um tratamento penal adaptado" 379 .

Conferir tratamento aos condenados seria uma tarefa a ser cumprida pelas prisões, um projeto político criminal que passa a ganhar contornos no Brasil a partir de meados do século XIX, registrando um grande crescimento no início do século XX. Flávio de Sá destaca que

377 GÓES, Luciano. A "tradução" de Lombroso na obra de Nina Rodrigues. Rio de Janeiro: Revan, 2016, p. 209.

378 GÓES, Luciano. A "tradução" de Lombroso na obra de Nina Rodrigues. Rio de Janeiro: Revan, 2016, p. 224.

379 ARAÚJO, João Vieira de. Sobre o novo Código penal. Revista Acadêmica da Faculdade de Direito do Recife. Ano 5, vol. 5, p. 130-18, 1895, p. 7. 
A partir do que ditava o Código Criminal de 1830, iniciou-se, no período em tela, a construção, em todo o Império, de estabelecimentos onde pudessem ser aplicadas as penas de prisão simples e, principalmente, de prisão com trabalho, objetivando a correção moral do criminoso e sua consequente devolução ao convívio social, morigerado, disciplinado e acostumado com a rotina do trabalho ${ }^{380}$.

O escopo de tratamento conferido a essas unidades está expresso nos seus regulamentos que são, de fato, verdadeiras receitas para curar a alma dos condenados. A Casa de Detenção do Recife, por exemplo, foi criada em 1855 e o seu primeiro regulamento proibia os presos de falarem alto (artigo 18), estabelecia o trabalho a ser realizado para cada categoria de presos como obrigatório e, no artigo 41, traçava o cotidiano quase militar que se desejava ali desenvolver:

Ao toque de acordar, todos os presos que não estiverem incomodados de saúde se levantarão da cama, farão a oração da manhã, e lavarão o rosto e as mãos, de maneira que as 6 horas já tenham concluído todas essas operações e estejão em estado de assistirem a missa e de receberem a visita dos médicos ${ }^{381}$.

No Rio de Janeiro, também a Casa de Correção do Império, fundada em 1850, tinha um regulamento rígido quanto à administração do tempo, do trabalho interno, das orações e do silêncio e incomunicabilidade entre os $\operatorname{presos}^{382}$.

Na virada para o século XX, essas ideias estão a todo vapor. Neste sentido, o decreto $n^{\circ} 145$ de 1893, emitido por Floriano Peixoto, previu a criação de uma colônia correcional no Distrito Federal, cujo escopo era a "correcção, pelo trabalho, dos vadios, vagabundos e capoeiras que forem encontrados, e como taes processados na Capital Federal”. Em São Paulo, em 1902, é criado o Instituto Disciplinar de Menores. No Recife, a Escola Correcional para menores funcionou de 1909 a 1929 no interior da CDR. Em 1929, é criada uma nova unidade, a Colônia Correcional para menores, com sede na cidade de Garanhuns e objetivando, segundo o seu regulamento (Ato 1.192 de 15 de outubro de 1929) ministrar

\footnotetext{
380 ALBUQUERQUE NETO, Flávio de Sá C. Da cadeia à Casa de Detenção: a reforma prisional no Recife em meados do século XIX. MAIA, C. N.; SÁ NETO, F. de; COSTA, M.; BRETAS, M. L. (orgs) História das prisões no Brasil. Volume II. Rio de Janeiro: Rocco, 2009, p. 76.

381 Regulamento da Casa de Detenção do Recife. 1855. Disponível em: $\langle$ http://objdigital.bn.br/acervo_digital/div_manuscritos/cmc ms618_21_79/cmc ms618_21_79.pdf> Acesso em 21 jul 2017.

${ }^{382}$ SANT'ANNA, Marilene Antunes. Trabalho e conflitos na casa de correção do Rio de Janeiro. MAIA, C. N.; SÁ NETO, F. de; COSTA, M.; BRETAS, M. L. (orgs) História das prisões no Brasil. Volume I. Rio de Janeiro: Rocco, 2009, p. 293.
} 
educação física, profissional e moral dos menores abandonados. Já a CDR manterá a sua missão regulamentar de corrigir os presos através também do trabalho.

Assim, os projetos correcionalistas são a expressão em termos político criminais das ideias positivistas na criminologia. A ligação tão trabalhada por Foucault entre poder disciplinar e saber criminológico estampa-se na obra desses autores e nos regulamentos prisionais do período, transformando-se em projetos de governo.

A utopia disciplinar é, portanto, uma realidade também no Brasil, apesar de seu desenvolvimento industrial tardio. Talvez isso reforce a interpretação de François Ewald sobre a relação entre o capital e a pena em Foucault, segundo a qual não teria sido o capitalismo industrial quem criou as disciplinas, mas estas, preexistentes, que teriam sido valorizadas, posto que funcionais ao sistema econômico em ascensão. Afinal, mesmo o senso comum coadunava da ideia de que a repressão à vadiagem, à ociosidade, às ocupações imorais estava ligada à necessidade de corrigir essas pessoas e torna-las mais úteis.

Como destaca Clarissa Nunes Maia, no Recife do final do século XIX, diversos trabalhos manuais como carregar e descarregar malas em porto, trabalhos domésticos, vendas de mercadorias nas ruas, trabalhos em obras públicas, dentre outros, dependia da mão-de-obra negra recém liberta. Ao mesmo tempo, a abolição deixou nas ruas um grande número de pessoas sem vínculo formal empregatício, constituindo uma verdadeira fonte de receio e medo da elite recifense ${ }^{383}$. Recolher esses indivíduos e "trata-los" era, portanto, uma ideia palatável não apenas entre criminólogos, mas na sociedade e, por certo, também entre policiais.

Isso foi visualizado nas revistas científicas da Polícia do Distrito Federal e nos relatórios dos chefes da polícia civil pernambucana. Para todos eles, a criminalidade advinha do ambiente nefasto em que viviam os indivíduos, cabendo às forças repressivas desmantelar esses lugares, recolher as pessoas que neles viviam e corrigi-las por meio do ensinamento da educação cívica, da moral sexual e da ética do trabalho.

Em 1917, a CDR passou a contar com oficinas de trabalho manual, empregando a mão-de-obra dos detentos. Para Antonio Magalhães, chefe de polícia à época, tais oficinas permitiam aos presos experimentarem "benefícios com o seu revigoramento físico e efeito moral, produzido pelo trabalho que em dias consecutivos lhes dará a ilusão bemfazeja de homens livres no exercício de sua nobilitante profissão", já nas horas de repouso, os presos, invariavelmente, refletiriam "sobre o seu passado, os maus actos que os conduziram à

\footnotetext{
${ }^{383}$ MAIA, Clarissa Nunes. Policiados: controle e disciplina das classes populares na cidade do Recife, 1865 1915. 252 f. Tese (Doutorado em História) - Universidade Federal de Pernambuco, Recife, 2001, p. 52.
} 
penitenciária". Em contato ainda com os funcionários cortezes da penitenciária, essas pessoas passariam necessariamente por uma "mudança de espírito". Enfim:

Livres, sadios, habituados ao trabalho diário, disciplinados, sabendo ler e escrever, com um ofício de que farão uso, encorajados com as reservas que acumularam, esses detentos voltarão ao meio de onde saíram com todas as probabilidades de serem úteis à pátria, à família e à sociedade ${ }^{384}$.

No relatório do chefe de polícia Arthur da Silva Rego, em 1922, a preocupação também é com os abandonados, os menores, os vagabundos, todos entregues ao óssio. Ele ainda destaca que a melhor forma de reduzir a criminalidade é por meio de ações preventivas, tal qual ensinado pela "sociologia criminal hodierna" - referindo-se, expressamente a Ferri. Os germens do delito, aludindo, aqui, diretamente à obra de Aurelino Leal, precisaram ser atacados, como era o caso do júri, mas não apenas isso. Criar prisões e casas correcionais também para os adultos era uma medida inadiável.

No relatório de 1928, Eurico de Souza Leão, apesar de se referir aos menores como a "malandragem criminosa do futuro", praticamente certo do destino daquelas pessoas, elogia a ação dos centros destinados a mendigos e outros indesejáveis da vida social, pois:

os incontáveis benefícios oriundos dessa obra social já se manifestam, intensamente, não só no fato das ruas da capital não mais apresentarem o triste aspecto de outrora, cortadas por indivíduos rôtos e chagados, como também em face do numero elevado de indivíduos portadores de doenças curáveis que hoje se encontram aptos para o trabalho, transformados, portanto, de elementos inactivos em força propulsora da economia nacional ${ }^{385}$.

Saindo das páginas dos tratados de antropologia e sociologia criminal esses discursos ganhavam corpo na forma de regulamentos e agenda de segurança pública, o que, afinal, era a pretensão dos teóricos. Para Zaffaroni, a hegemonia dos saberes criminológicos positivistas "chegou quando o seu discurso foi assumido pela corporação policial"386. Ou seja, é quando ele ganha corpo e materialidade que se torna um saber inquestionável e útil.

Ao ler sobre essa expertise dos chefes de polícia e outras altas autoridades policiais, eu me perguntei muito ao longo desse trabalho se praças e soldados, ou mesmo delegados e

\footnotetext{
${ }^{384}$ APEJE, Fundo SSP, Caixa 2. Relatório da Chefia de Polícia, 1918, p. 100.

385 APEJE, Fundo Secretaria de Justiça, Livro 202, Relatório da Chefia de Polícia, 1928, p. 9.

386 ZAFFARONI, Eugenio Raul. Las "clases peligrosas": el fracasso de un discurso policial prepositivista. Sequência, Ano XXV, dezembro, p. 141-168, 2005, p. 143.
} 
subdelegados, muitos dos quais nunca haviam passado pelos bancos da universidade ou cursos de formação, conheciam todo esse debate. Evidentemente, eles são subordinados e devem obediência às ordens e às prioridades estabelecidas pela Chefia de Polícia. Porém, são eles quem realizam, nas ruas, o papel fundamental de suspeição e abordagem e eles que prendiam e soltavam a torto e a direito os "sujeitos criminais" descritos pela criminologia.

Depois, refleti que o questionamento não fazia sentido, na medida em que a criminologia positivista, apesar de toda a sua carga de cientificismo, não passa de uma teoria do senso comum, imprimindo em teses a prática punitiva do dia a dia, afinal, "a racialização dos sistemas penais ocorreu na história" ${ }^{387}$, constituiu-se com ele. Evidente que, nos campos jurídico, médico, político e na formulação de uma programação criminalizante, a criminologia positivista, que é uma especialização do racismo científico ${ }^{388}$, cumpre a fundamental tarefa de legitimação do sistema penal, autorizando a perpetuação de algumas práticas e solicitando a modificação de outras.

Mas, nas ruas, valia mais a experiência e o acúmulo de prática policial. O samba, a bebedeira, os jogos, as vozerias, o maxixe, a prostituição, tudo isso, como se viu, eram condutas descritas como desviantes nas Posturas Municipais ao longo de todo o século XIX e, desde então, alvo da atuação das polícias, antes de quaisquer dessas formulações teóricas amadurecerem. Na Primeira República esse padrão pouco se alterou.

Porém, entender o padrão punitivo do período e as práticas policiais a partir desses discursos e dos documentos oficiais como leis e regulamentos prisionais é insuficiente. A partir apenas deles, poderíamos afirmar sem grandes dificuldades que o Brasil teria vivenciado verdadeiramente uma mudança na penalidade, a qual deixaria de se basear no suplício, na dor e na exclusão do condenado - açoites, galés, pena de morte - e passaria a ter investido na disciplina da alma, formando assim uma massa de mão de obra docilizada para as fábricas.

Porém, como argumentado no capítulo anterior, o padrão de controle policial, embora recaísse sobre os sujeitos que essa criminologia descrevia como perigosos, não se dava nos moldes sonhados por chefes de polícia, juristas e médicos. Longe do padrão disciplinador, a mecânica policial parecia incidir preferencialmente sobre corpos, controlando sua circulação nas ruas, permitindo e proibindo presenças em determinados locais, infringindo dor em

387 DUARTE, Evandro P; QUEIROZ, Marcos V. L.; COSTA, Pedro A. A hipótese colonial, um diálogo com Michel Foucault: a modernidade e o Atlântico Negro no centro do debate sobre racismo e sistema penal. Universitas JUS, volume 27, n. 2, p. 1-31, 2016, p. 27.

${ }^{388}$ DUARTE, Evandro Piza. Paradigmas em criminologia e relações raciais. Caderno CEAS, Salvador, n. 238, p. 500-525, 2016, p. 507. 
cárceres superlotados e não poupando, por vezes, o que se chamava no Recife de "pau e corda". Essa imagem mais se assemelha a do regime escravista, isto é, a da disciplina dos açoites.

\subsection{A DISCIPLINA DOS CORPOS SEM ALMA}

Como já comentei acima, Foucault pretendeu demonstrar que a modernidade inaugurara uma nova forma de sociedade, que ele chamou de disciplinar ou ortopédica. Nesta, a punição não mais se voltava ao corpo, infligindo nele dor, mas à alma, pretendendo normalizá-la. Por que a ruptura com o modelo dos suplícios públicos teria sido necessária?

As razões apontadas por ele são muitas, mas me atenho a duas delas. Primeiramente, o suplício é um ritual de restauração da autoridade do soberano, fundamental nos regimes políticos monárquicos absolutistas, mas também um espaço onde o povo poderia vir a se voltar contra esse mesmo soberano, na hipótese de se identificar com ou até mesmo se compadecer do condenado ${ }^{389}$. Assim, abandonar os suplícios públicos poderia ser uma estratégia contra eventuais sublevações populares.

Em segundo lugar, as demandas do capitalismo industrial eram por corpos vivos e preferencialmente treinados para o trabalho. O suplício, portanto, era disfuncional ao sistema econômico. Uma nova economia da pena propunha mudanças que tornassem o sistema punitivo mais racional, credível, sereno e, obviamente, útil. O objetivo das disciplinas era fabricar corpos politicamente dóceis e economicamente úteis, como afirma Foucault.

Por essa razão, mesmo distante dos textos dos autores da Escola Clássica, como Cesare Beccaria, a prisão teria se tornado a pena por excelência a partir do século XVIII, porque correspondia às demandas do poder disciplinar. Foucault, em sua analítica do poder, propõe uma análise que supera as delimitações do direito. No modelo jurídico, "o poder seria descrito em termos de interdição, manifestando-se essencialmente através da enunciação da lei, que proíbe ou permite, que determina o que é lícito ou ilícito" ${ }^{390}$. No modelo da normalização, o poder é vislumbrado como uma relação de forças que produz gestos, discursos e individualidades.

Portanto, o sentido de disciplina na modernidade foge à simples noção de "imposição de limites ou restrições" ${ }^{391}$. As disciplinas são "métodos que permitem o controle minucioso das operações do corpo, que realizam a sujeição constante de suas forças e lhes impõem uma

\footnotetext{
${ }^{389}$ FOUCAULT, Michel. Vigiar e punir. 35a ed. Rio de Janeiro: Vozes, 2008, p. 42.

${ }^{390}$ FONSECA, Márcio Alves da. Michel Foucault e o direito. São Paulo: Saraiva, 2014, p. 103.

${ }^{391}$ FONSECA, Márcio Alves da. Michel Foucault e o direito. São Paulo: Saraiva, 2014, p. 107.
} 
relação de docilidade-utilidade" ${ }^{392}$. A disciplina fabrica corpos dóceis, em um ambivalente processo de aumentar a sua força em utilidade, ao mesmo tempo em que reduz a sua força política, gerando seres obedientes.

As técnicas para o exercício dessa disciplina, em uma instituição perfeita, seriam: a vigilância hierárquica, a sanção normalizadora e o exame. Tudo isso estaria contemplado no modelo benthiano do panóptico, arquitetura adotada em diversas unidades prisionais do século XIX.

A vigilância hierárquica desenvolve-se de forma constante. É indiscreta porque está em toda parte, mas discreta porque atua silenciosamente. Já as sanções normalizadoras seriam pequenos mecanismos penais que funcionam nas instituições disciplinares, prontas para punir todo e qualquer pequeno desvio. Punir, entretanto, não apenas para retribuir, mas, sobretudo, para corrigir, visando a modificar o comportamento dos indivíduos. Mais uma vez aqui, o corpo é objeto de intervenção, não para simples imposição de dor e sim como forma de acessar a alma do indivíduo, normalizando-a. Por fim, essas estruturas disciplinares demandam o exame como estrutura capaz de qualificar, classificar e punir ${ }^{393}$.

Para conhecer esse indivíduo, a justiça penal tomará emprestados os discursos sobre esse ser, sobretudo os construídos no campo médico e psiquiátrico. O exame psiquiátrico é o principal documento utilizado para deslocar a intervenção punitiva do ato para o sujeito e, ao mesmo tempo, para definir positivamente o sujeito delinquente ${ }^{394}$. Nas palavras do autor, “o exame tem por função dobrar o autor, responsável ou não, do crime, como um sujeito delinquente que será objeto de uma tecnologia específica"395.

Por fim, para Foucault, a disciplina não se exerceria apenas no interior dos muros da prisão, mas fora deles. Desse modo, nomear os indisciplinados, reconhecê-los é uma tarefa muito mais ampla que o empreendimento prisional, perpassando agências policiais e judiciais.

Uma importante distinção entre o âmbito do direito e das disciplinas é feita na obra do autor e ressalto-a para desenvolver meu argumento. Ao direito caberia uma parte da organização social; porém, paralelamente a ele, outros mecanismos de disciplina seriam desenvolvidos, à margem da lógica jurídica strictu sensu. De fato, "Foucault não vê uma sucessividade entre direito e disciplina, que em nenhum momento são relacionados por qualquer vínculo"396. A disciplina é, para Foucault, o outro lado do Estado de Direito.

\footnotetext{
${ }^{392}$ FOUCAULT, Michel. Vigiar e punir. $35^{\mathrm{a}}$ ed. Rio de Janeiro: Vozes, 2008, p. 118.

${ }^{393}$ FOUCAULT, Michel. A verdade e as formas jurídicas. Rio de Janeiro: Nau Editora, 2009, p. 154.

${ }^{394}$ FOUCAULT, Michel. Os anormais. São Paulo: Martins Fontes, 2013b, p. 18-19.

${ }^{395}$ FOUCAULT, Michel. Os anormais. São Paulo: Martins Fontes, 2013b, p. 19.

${ }^{396}$ CHAVES, João. O problema do direito em Michel Foucault. Curitiba: Juruá, 2010, p. 40.
} 
O argumento é: a redistribuição de diretos e poder, com o advento das revoluções burguesas, geraram uma massa de novos cidadãos que representavam uma ameaça à mesma ordem burguesa. As disciplinas seriam, então, o contradireito; seriam a "contrapartida política das normas jurídicas segundo as quais era redistribuído o poder" ${ }^{397}$. Essa interpretação nos parece bastante útil para entender, por exemplo, que o medo da "horda" de ex-escravos, de imigrantes, de homens e mulheres que perambulam pelas cidades, nos séculos XIX e XX, ensejou a criação de aparelhos do sistema punitivo, incluindo a própria polícia. Para toda aquela massa de novos cidadãos, haveria uma estrutura disciplinar para conter excessos, para ensiná-los a serem "bons cidadãos".

Foucault dedica algumas páginas de Vigiar e Punir a pensar a polícia, identificando-a como uma instituição que desenvolve esse tipo de poder disciplinar, fugindo à lógica de simples organização da soberania estatal. E aqui cumpre fazer uma ressalva: ao definir soberania policial eu optei por desvincula-la da soberania estatal, justamente por entender que seus mecanismos iam além do mando de um monarca ou governante. Foucault pensará a polícia como aquela força que liga o poder soberano e os micropoderes sociais, que obedece ao soberano, mas também responde aos anseios sociais de ordem e disciplina. A polícia, "bem melhor que a instituição judiciária, ela se identifica, por sua extensão e seus mecanismos, com a sociedade do tipo disciplinar" ${ }^{398}$.

Pode-se sistematizar a ideia defendida por Foucault da seguinte forma: a polícia é uma manifestação do poder disciplinar, porque a) em sua extensão, espraia-se por toda a sociedade, alcançando as relações infinitesimais; b) objetiva vigiar a todos e a tudo e c) mantem a ordem social ao desempenhar um papel normalizador sobre os desordeiros, encaminhando-os para as unidades de tratamento e adestramento (como prisões, manicômios, forças armadas etc).

Toda essa descrição parece estar em pleno acordo com os discursos apresentados no tópico anterior, afinal, como lembrava João Vieira de Araújo, o direito penal deveria se preocupar em tratar os indivíduos. Todo o discurso correcionalista desenvolvia exatamente essa mecânica entre vigilância e disciplina.

Porém, embora a polícia estivesse capilarizada, já foi mencionado o quanto, na prática, nem seus agentes eram peças de um mecanismo disciplinador (porque sempre abertos a negociações, acordos, corrupção), nem os corpos vigiados eram submetidos a verdadeiros processos de educação normalizadora. A soberania policial tal qual exercida no Recife - e em

\footnotetext{
${ }^{397}$ FOUCAULT, Michel. Vigiar e punir. $35^{\mathrm{a}}$ ed. Rio de Janeiro: Vozes, 2008, p. 184.

${ }^{398}$ FOUCAULT, Michel. Vigiar e punir. 35 a ed. Rio de Janeiro: Vozes, 2008, p. 177.
} 
outras cidades brasileiras - era o oposto das disciplinas descritas por Foucault e também o outro lado do direito.

Era a gestão das populações sim, mas com as marcas de uma burocracia pouco profissionalizada e altamente fissurada pelo personalismo, aliado a uma herança escravocrata que gestava corpos com açoites e não com ordens discretas. Era o patrimonialismo e o racismo nas suas formas mais puras.

Voltemos à CDR. Surgida em 1855, ela tem uma arquitetura panóptica e sua construção, à época, foi bastante elogiada. O regulamento, cujos trechos foram antes citados, previa uma verdadeira casa de correção, aos moldes dos regulamentos citados por Foucault em Vigiar e punir e, portanto, seguindo a tendência moderna de unidades voltadas à normalização. Porém, é preciso lembrar, como o fez Clarissa N. Maia, que o sonho disciplinar do regulamento "caía por terra ao se deparar com as condições materiais do presídio e a indisciplina e corrupção dos guardas do estabelecimento" ${ }^{399}$. Na CDR, os presos eram amontoados e a grande maioria, sequer, podia trabalhar ${ }^{400}$.

O mesmo quadro foi observado por Andrei Koerner, analisando a realidade da Casa de Correção do Império, surgida também na década de 1950, no Distrito Federal. Para o autor, a experiência prisional, no Rio de Janeiro do século XIX, evidencia um fracasso do panoptismo em nosso país. Não um insucesso, entretanto, de toda técnica de disciplina. Na Casa de Correção do Rio de Janeiro, o vigilante não se ocultava e não exercia uma vigilância discreta e silenciosa; ele mantinha-se "personificado, visível, concreto e próximo, como uma ameaça para os subordinados" $" 401$.

A obediência para a realização dos trabalhos forçados seria adquirida com a força, independentemente da reforma da alma do indivíduo. Consequentemente, as sanções disciplinares não seriam, necessariamente, normalizadoras, afinal, nem todos os corpos recolhidos à Casa de Correção do Império precisariam ser preservados e, com eles, suas

399 MAIA, Clarissa N. A Casa de Detenção do Recife: controle e conflitos (1855-1915). MAIA, C. N.; SÁ NETO, F. de; COSTA, M.; BRETAS, M. L. (orgs) História das prisões no Brasil. Volume I. Rio de Janeiro: Rocco, 2009, p. 117.

400 É importante destacar que esse suposto fracasso da prisão é reconhecido pelo próprio Foucault nas últimas páginas de "Vigiar e Punir". Foucault afirma que ela não teria sido capaz de corrigir almas. Concebendo o projeto da prisão disciplinar como algo não realizável porque não reduziria os crimes e não ressocializaria os indivíduos, o autor, entretanto, não admitirá o seu fracasso. Nas últimas páginas de Vigiar e punir, ele lança outra ideia sobre a prisão: "O sucesso da prisão: na luta em torno da lei e das ilegalidades, especificar uma 'delinquência”". FOUCAULT, Michel. Vigiar e punir. $35^{a}$ ed. Rio de Janeiro: Vozes, 2008, p. 230. Assim, ao identificar a delinquência, fechá-la em relação a outras ilegalidades e puni-la, a prisão construía a imagem do tipo criminoso ideal, o qual seria objeto de atenção da polícia e das vigilâncias. Além disso, a prisão poderia até mesmo produzir colaboradores, ex-criminosos que estariam dispostos a cooperar com as agências do sistema punitivo. Ele, então, desenvolve o conceito de delinquência útil.

${ }^{401}$ KOERNER, Andrei. Punição, disciplina e pensamento penal no Brasil do século XIX. Lua Nova, São Paulo, 68, p. 205-242, 2006, p. 219. 
almas. Disciplinar a alma de escravos condenados a penas longas era uma tarefa inútil, já que, após o longo período de internação, não mais suportaria os trabalhos braçais. A morte dentro da prisão era funcional à sociedade escravista ${ }^{402}$.

Koerner observa, portanto, que, do ponto de vista da organização prisional, temos um "panóptico tropical” impossível. Porém, não se trata de um projeto incompleto de sociedade disciplinar. A própria disciplina escravista alia os castigos corporais a um cálculo econômico dos proprietários. A violência física não é ilimitada, pois era preciso preservar viva a força produtiva. Desse modo, o castigo corporal visava a adestrar para extrair utilidade desses corpos, formulação esta muito próxima àquela realizada por Foucault a respeito da construção dos corpos dóceis e úteis.

Desse modo, Koerner nos coloca a pensar sobre uma sociedade disciplinar em que a força bruta sobre o corpo se alia à pretensão de adestramento da alma. Isto é, um projeto disciplinar sem qualquer pretensão "humanizadora"... Essa particularidade tem levado autores da sociologia e criminologia brasileiras a repensar as leituras críticas sobre o sistema punitivo que, apesar de questionadoras, continuam a ser importadas sem maiores ponderações da Europa ou Estados Unidos para o nosso continente. Não pretendo aqui desenvolver o debate sobre a possibilidade ou não de uma criminologia genuinamente latino-americana, mas, de certo, é fundamental, entender que "nossos fenômenos, abarcados sob o que mais ou menos tradicionalmente se chama 'criminologia', são qualitativa e quantitativamente diferentes dos que procuram explicar os teóricos ordenadores dos países centrais" ${ }^{403}$, como advertiu Zaffaroni desde a década de 1980 em seu "Criminologia desde un margen".

Nessa linha, a contribuição do pensamento de Luciano Oliveira para a releitura de Foucault, mas, sobretudo, de Vigiar e Punir, é crucial. Em seu trabalho, Oliveira parte, primeiramente, das críticas já realizadas à obra foucaultiana e relacionadas a possíveis incongruências nas descrições que Foucault faz dos fatos históricos que justificariam a formação de uma sociedade disciplinar, os quais seriam contados e interpretados de forma um tanto parcial, de modo a justificar as hipóteses do autor ${ }^{404}$.

Mas Oliveira se debruça também sobre estudos históricos que, observando empiricamente as prisões do século XIX e início do século XX no Brasil, demonstram que

\footnotetext{
402 KOERNER, Andrei. Punição, disciplina e pensamento penal no Brasil do século XIX. Lua Nova, São Paulo, 68, p. 205-242, 2006, p. 221.

${ }^{403}$ ZAFFARONI, Eugênio Raul. Criminologia: aproximación desde un margen. Bogotá: Editorial Themis, 1988, p. 2.

${ }^{404}$ OLIVEIRA, Luciano. O aquário e o Samurai: uma leitura de Michel Foucault. Rio de Janeiro: Lumen Juris, 2017, p. 57.
} 
a prisão brasileira desmente dois pressupostos fundamentais de uma instituição disciplinar no sentido foucaultiano do termo: ao invés do adestramento das almas, o espancamento na rua ou no posto policial; ao invés do 'princípio da inversão das masmorras' a masmorra como princípio $^{405}$.

E isso não é um detalhe! A teoria foucaultiana sobre a sociedade disciplinar, embora bastante pessimista sobre as novas formas de punição e seu falso humanismo, fala de uma ruptura que jamais existiu no Brasil: aquela que deixou para trás o corpo como objeto de intervenção e passou a investir nas almas. Um investimento, aliás, como já dito, para além dos muros da prisão e realizado no projeto de escolarização nacional, do alistamento e do treinamento militar, das intervenções médicas e higienistas sobre a população, no controle sobre a sexualidade, nas interações do dia a dia etc. Enfim, uma sociedade normalizada depende de fatores materiais que não existiram no Brasil.

Sendo assim, garantir um mínimo de ordem nas cidades foi uma tarefa do velho "pau e corda”, já que com essas condições disciplinadoras não se poderia efetivamente contar.

A sociedade brasileira do início do século XX parecia conjugar duas tendências aparentemente opostas: um discurso jurídico, político, médico e criminológico disciplinador e ressocializador e uma prática de ordenamento de corpos baseado no poder policial nas "ruas", sem grandes intermediações jurídicas ou de estruturas públicas educativas, tendo como alvo corpos e não almas.

Esses duas tendências, apesar de aparentemente contraditórias, acabaram por se tornar complementares. O saber criminológico cumpriu um papel importante de legitimação do sistema penal e suas desigualdades, nomeando o "criminoso natural" e apontando para fatores criminógenos no "meio" periférico, nos cortiços e nos mucambos. Ele foi fundamental para demarcar o "caos delinquencial" dos povos selvagens que habitavam o Brasil.

Luciano Góes demonstra como o "medo do negro e suas características violentas ontológicas faz com o que o autor [Nina Rodrigues] se reporte à Revolução Haitiana, e mais tarde, em outro estudo, a Palmares chamado de "Troia Negra" ${ }^{406}$, alertando para a necessidade de um controle racial em termos de vigilância constante, afinal, eram serem quase animalizados, sem alma.

No campo das ideias, um Nina Rodrigues, portanto, podia facilmente explicar as estatísticas e práticas policiais, sobre as quais falei no capítulo anterior e que justamente

${ }^{405}$ OLIVEIRA, Luciano. O aquário e o Samurai: uma leitura de Michel Foucault. Rio de Janeiro: Lumen Juris, 2017, p. 73.

${ }^{406}$ GÓES, Luciano. P. A "Tradução" de Lombroso na obra de Nina Rodrigues. Rio de Janeiro: Revan, 2016, p. 212-213. 
recaiam sobre essas pessoas. Porém, ao contrário do intervencionismo recuperador derivado das concepções positivistas europeias, o sistema penal no Brasil não abandonou, na prática, os suplícios e as masmorras, o que, por outro lado, não parecia incoerente quando se pensa que, como seres bestiais e incivilizados, a população negra e pobre deveria estar submetida a práticas de contenção ou eliminação.

A desumanidade do racismo é coerente com a manutenção da barbárie nas práticas de controle social, não havendo, portanto, total contradição entre os discursos e práticas no campo criminal.

Esse dado precisa ser levado em consideração. Hoje, pensando-se em uma "brasilidade" da criminologia, vários autores vêm perquirindo sobre as particularidades de nosso país, mormente quando o sistema punitivo moderno é importado de legislações europeias liberais, mas erige-se em uma sociedade escravocrata e que tem no racismo um elemento estruturador. Mais do que isso e para além das estatísticas demonstrarem uma seletividade racial, uma maior exposição de negros a penas mais violentas e tratamento mais degradante, "não poderia ter existido a construção negativa da raça sem sistema penal, e não se pode compreender o sistema penal sem a construção das relações raciais"407.

Neste sentido, Vera R. P. de Andrade, Marcelo Mayoara e Mariana Garcia questionam também os pressupostos das obras de Rusche e Kirchheimer e de Foucault, as quais estavam vinculadas a uma realidade europeia, na qual a prisão surge atrelada às necessidades do capitalismo. O que mudaria se pensássemos a prisão e outras formas de controle penal sendo desenvolvidas em uma sociedade escravocrata ${ }^{408}$ ? Em uma sociedade em que, como pontuado, o liberalismo e a escravidão deram a tônica da nossa programação criminalizante?

Segundo Camila Prando, a análise foucaultiana e também a clássica hipótese materialista como as de Rusche e Kirchheimer ou Pavarini e Melossi teriam dois problemas que precisariam ser considerados: a) o primeiro deles, o de dar centralidade em suas explicações sobre a penalidade à pena privativa de liberdade quando, em nosso continente, ela é uma realidade que convive lado a lado com a pena de morte extraoficial; e b) o fato de tomarem por base o desenvolvimento dos sistemas punitivos no cenário europeu, onde o

\footnotetext{
407 DUARTE, Evandro P; QUEIROZ, Marcos V. L.; COSTA, Pedro A. A hipótese colonial, um diálogo com Michel Foucault: a modernidade e o Atlântico Negro no centro do debate sobre racismo e sistema penal. Universitas JUS, volume 27, n. 2, p. 1-31, 2016, p. 26.

408 ANDRADE, Vera R. P. de; MAYOARA, Marcelo; GARCIA, Mariana D. de O. O controle penal na sociedade escravocrata: contributo da economia política da pena para a compreensão da brasilidade. Discursos sediciosos: crime, direito e sociedade. Ano 20, números 23/24, p. 162-178, 2016, p. 167.
} 
monopólio da violência por parte do Estado se concretizou muito mais do que no cenário da América Latina ${ }^{409}$.

De fato, do lado de cá do equador, nem a prisão se constituiu como a principal das formas de punição e não elidiu os métodos informais de resolução de conflitos.

Volto, então, à reflexão de Luciano Oliveira acerca da recepção "sem moderação" do pensamento crítico brasileiro à leitura de Foucault. No capítulo anterior, mencionei algumas dezenas de casos de prisões de prostitutas, ébrios, menores, loucos, vagabundos, que representavam muito mais da metade das prisões realizadas na cidade do Recife. Ao se insistir tanto no papel disciplinar do cárcere, esqueceu-se de verificar o que, de fato, ocorria com essas pessoas.

Essas prisões, como também já ressaltado, eram de curtíssima duração. Analisando as entradas na Casa de Detenção do Recife, nos meses de setembro e outubro de 1920, verificamos que elas duravam, em regra, menos de 10 dias.

Tabela 16: Duração da prisão - geral, por sexo e por cor ${\text { (percentual })^{410}}^{40}$

\begin{tabular}{lllllllllll}
\hline $\begin{array}{l}\text { Cor/sexo } \\
\text { tempo da } \\
\text { prisão }\end{array}$ & $\begin{array}{l}\text { Liberado } \\
\text { no mesmo } \\
\text { dia }\end{array}$ & $\begin{array}{l}\mathbf{1} \text { a } 5 \\
\text { Dias }\end{array}$ & $\begin{array}{l}\text { 6 a 10 } \\
\text { Dias }\end{array}$ & $\begin{array}{l}\text { 11 a 20 } \\
\text { Dias }\end{array}$ & $\begin{array}{l}\text { 21 a 40 } \\
\text { Dias }\end{array}$ & $\begin{array}{l}\text { 41 a 60 } \\
\text { Dias }\end{array}$ & $\begin{array}{l}\text { Mais de } \\
\text { 60 dias }\end{array}$ & $\begin{array}{l}\text { Ilegível } \\
\text { Presos/as } \\
\text { Encaminhados } \\
\text { ao Hospital de } \\
\text { Alienados }\end{array}$ \\
\hline Total & 5,1 & 38,3 & 12,9 & 9,4 & 2,1 & 2,1 & 1,7 & 43,1 & 23,2 \\
Branca & 9,8 & 39,5 & 8,6 & 9,8 & 0 & 2,4 & 0 & 2,4 & 29,4 \\
Negra & 2,9 & 40 & 16,2 & 10 & 3,7 & 2,2 & 2,9 & 5,9 & 21,4 \\
Mulheres & 0 & 12,9 & 3,2 & 3,2 & 0 & 6,4 & 0 & 3,2 & 70 \\
Homens & 6 & 42,9 & 14,6 & 10,6 & 2,5 & 1,5 & 2,0 & 3,5 & 16,1 \\
\hline
\end{tabular}

Fonte: APEJE - Fundo SSP - Livro de entradas e saídas da CDR - 1920/Elaboração própria

Esse aspecto era, inclusive, constantemente reclamado pela cúpula policial, que expressavam tendências correcionalistas, conforme já observado. O chefe de polícia, em 1914, lembrava que era muito inconveniente o fato de presos serem recolhidos apenas de forma momentânea, sem vivenciarem atividades mediante as quais sairiam mais disciplinados da prisão:

Constitui uma preocupação constante para a polícia, o destino a dar ao número assustador de menores vadios vezeiros na prática de furtos e

\footnotetext{
${ }^{409}$ PRANDO, Camila C. de M. A contribuição do discurso criminológico latino-americano para a compreensão do controle punitivo moderno controle penal na américa latina. Belo Horizonte: Veredas do direito, v.3, n. 6, jul/dez, 2006, p. 83.

${ }^{410}$ APEJE, Fundo SSP, Casa de Detenção do Recife. Livro de entradas e saídas. 1920.
} 
arruaças e habituados já a prisão momentânea ou correcional nos xadrezes das subdelegacias ou na casa de Detenção ${ }^{411}$.

No mesmo sentido, partilhando dessa sensibilidade correcionalista, o juiz José Burle de Figueiredo, ao se referir aos vadios, queixa-se da forma tradicional com a qual a polícia lidava com esses vagabundos, reprimindo apenas, sem nada acrescentar-lhes à alma. Para ele, lidar com a vadiagem era uma questão de prevenção, "com o fim de reeducar e adaptar ao meio social, os indivíduos que, em virtude de suas condições de vida, se presumam perigosos, conquanto ainda não tenham delinquido ou dado provas pessoaes de uma periculosidade latente" 412 .

Aquelas pessoas, entretanto, longe do controle disciplinar, estavam expostas ao controle direto policial, um controle presente, corpo a corpo, ora do tipo repressivo, ora do tipo paternal. Enfim, a utopia disciplinar é o outro lado da moeda da soberania policial.

\subsection{A SOBERANIA POLICIAL CONTRA A UTOPIA DISCIPLINAR OU EU "PROCEDO COMO QUISER NAS HORAS DE SERVIÇO”}

Foucault, ao mencionar os dispositivos disciplinares, em Vigiar e Punir, nada fala acerca dos agentes de Estado que ocupariam funções em unidades como a prisão ou que, nas ruas, desempenhariam o papel de polícia. Há, sempre, menção ao "dispositivo", ao "sistema", como se eles tivessem vida própria.

Não é possível entender o sistema punitivo sem perceber esses atores. A soberania policial não é o exercício de agentes policiais obedientes, que seguem à risca as ordens de seus superiores, que, por sua vez, é emanada dos chefes de governo. Ao contrário, esse era um dos principais desafios dos governos ao longo do século XIX e início do século XX: como lidar com agentes policiais indisciplinados?

A soberania policial é o outro lado da moeda das disciplinas. É o terreno da insubordinação, dos poderes independentes. Fora isso, as polícias possuíam baixos recursos, de modo que, nem que desejassem, teriam estruturas de vigilância tão aprimoradas e eficazes.

De fato, uma constante no período estudado era a insuficiência numérica desses policiais na rua e certa indisciplina por parte deles. Entre as ordens emanadas da Chefia de Polícia e a sua execução havia uma distância que, por vezes, admitia o fortalecimento de

\footnotetext{
411 APEJE, Fundo Secretaria Geral, Livro 190, Relatório da Chefia de Polícia, p. 15.

${ }^{412}$ FIGUEIREDO, José Burle de. A contravenção de vadiagem. Rio de Janeiro: Jacintho Ribeiro dos Santos Editor, 1924, p. 12.
} 
micropoderes locais, a cargo de autoridades como os subdelegados e mesmo os próprios praças e guardas.

Um episódio ocorrido em 1917, na delegacia de Santo Antonio, é bem ilustrativo. Em um ofício do dia 26 de junho daquele ano, encaminhado à Chefia de Polícia, o subdelegado José Primo D’oliveira afirma que a sua unidade policial (a $1^{\mathrm{a}}$ subdelegacia da capital) se situa em região insalubre, que não possui higiene e que os que procuram o serviço policial saem insatisfeitos. Também afirma que o policiamento é deficiente, devido ao reduzido número de praças e demonstra, rua a rua, como se da essa insuficiente distribuição ${ }^{413}$.

Além da falta de praças, faltava material. Ao comentar sobre a condução de ébrios para a delegacia, fala que a polícia é obrigada a conduzi-los a pé, recebendo pontapés durante todo o percurso e, ao mesmo tempo, sob vaias e protestos da sociedade ${ }^{414}$.

Essa imagem contrasta bastante com aquela de uma polícia moderna à la Sherlock Holmes idealizada por chefes de polícia no Brasil. As investigações sagazes, científicas e precisas cediam lugar a um improviso como o descrito acima. E quando o tal ébrio chegasse à Delegacia de Polícia, após dar pontapés em praças e soldados, já dá para imaginar o que poderia acontecer...

Sendo assim, quando somamos todos os elementos já aqui referidos sobre as forças policiais - falta de formação, baixo profissionalismo, ausência de pessoal e material, frouxidão nos regulamentos sobre o padrão de atuação, independência para agir de seus membros em todos os níveis da organização - chega-se a um terreno em que o que ocorre na rua deixa de ser uma questão de lei e direito, para se tornar um problema dos policiais, onde cada autoridade faz o que quer. Neste cenário, negociações, acordos, disputas entre diferentes policiais e arbitrariedades são elementos frequentes que substituem a rígida disciplina "sonhada" pelos positivistas criminológicos, chefes de polícia, médicos e juristas. Nas próximas páginas, aprofundo um pouco melhor esse argumento a partir de narrativas também dos arquivos policiais.

\subsubsection{Negociações e acordos}

Em um ofício de 4 de agosto de 1921, o delegado do $1^{\circ}$ Distrito da Capital, Liberalino de Almeida, enviou um ofício ao Chefe de polícia, informando sobre uma denúncia feita pelo administrador do Mercado de São José contra o subdelegado do distrito de São José, o qual

\footnotetext{
${ }^{413}$ APEJE, Fundo SSP, livro 458. Livro de Ofícios de Delegados e Subdelegados da $1^{\text {a }}$ Delegacia de Polícia. 1917.

${ }^{414}$ APEJE, Fundo SSP, livro 458. Livro de Ofícios de Delegados e Subdelegados da $1^{\text {a }}$ Delegacia de Polícia. 1917.
} 
estaria favorecendo, de forma arbitrária, alguns desordeiros que perturbam a ordem naquele estabelecimento.

Na primeira das situações, narra o delegado, um suineiro de nome Felix Ferreira da Costa teria ferido a faca um ganhador no mercado de São José. Suineiros eram vendedores de carne suína, mas também poderiam ser a denominação de agremiações de frevo que, no início do século XX, costumavam fazer alusão a tipos de trabalho, assim como pás, vassourinhas, espanadores. Pela forma narrada, possivelmente Felix Ferreira era um capoeira. O fato foi que, após ser preso, teria sido solto pelo subdelegado mediante o pagamento de $107 \$ 000$, sem ser processado.

Esse fato, totalmente frequente na dinâmica policial da época, teria incomodado o administrador do mercado de São José ${ }^{415}$, para quem a sua autoridade teria se enfraquecido diante de uma total facilidade com a qual Felix Ferreira teria sido solto.

O outro caso era o de Antonio Lopes, preso pela administração daquele mesmo mercado em razão de ter galanteado a filha de um negociante. Ao ser preso, foi encontrado com ele uma pistola "mauser" e ele teria se negado a pagar a multa pela infração municipal de andar com arma proibida. Em razão disso, a arma ficou retida com a administração do mercado e Antonio Lopes foi encaminhado à delegacia, sendo liberado a pedido do cunhado do subdelegado, referido no ofício como o Sr. Pereira.

No dia seguinte, o subdelegado mandou um soldado ao mercado para dizer ao administrador que devolvesse a arma, mas o administrador se recusou a fazê-lo sem que Antonio Lopes pagasse a multa. Tempos depois, o tal cunhado, o Sr. Pereira, compareceu ao mercado, pagou a multa e pegou a pistola de Antônio de volta.

Ora, na época, a posse de arma proibida era uma contravenção, prevista no artigo 377, como "Usar de armas offensivas sem licença da autoridade policial". Mas tudo se resolveu entre o subdelegado, o seu cunhado e Antônio, ao que parece, de forma muito natural e sem maiores alardes, já que, no ofício citado, o delegado não pedia providência contra o subdelegado e seu cunhado, mas contra o administrador do Mercado, que estaria se arvorando indevidamente nas funções policiais.

Assim, o fato de um familiar do subdelegado intervir em conflitos policiais não parecia causar espécie ao delegado. A questão era outra e dizia respeito ao poder de mando naquela região. Quem, afinal, teria autoridade sobre os conflitos ocorridos no Mercado de São

\footnotetext{
${ }^{415}$ É importante mencionar que, desde o século XIX, o administrador do Mercado de São José possuía poder de polícia, podendo prender e cobrar multa de frequentadores ou comerciantes que praticassem infrações em seu interior, o que, para a Polícia, poderia ser um inconveniente, pois significava que, ali, seu poder seria dividido com alguém alheio à administração policial.
} 
José? Naquele ofício, o delegado reivindicava à Chefia de Polícia a garantia da soberania policial.

Esses acordos remetem ao conceito de "mercadoria política" cunhado muito tempo depois desses fatos por Michel Misse, mas que me parece instrumental. Segundo o autor, a violência urbana em crescimento no Rio de Janeiro das décadas de 1970 e 1980 se devia a uma acumulação social da violência naquela cidade, que foi palco de diversos tipos de mercados ilícitos como os de jogos de azar, da prostituição, de material pornográfico, de produtos contrabandeados, e, paulatinamente em crescimento, na segunda metade do século $\mathrm{XX}$, de drogas ilícitas.

Porém, ao lado desses mercados ilícitos, existia outro tipo de mercado, também ilegal, que ele chamará de político. Neste, negociam-se fiscalização, prisões e proteção; nele, agentes do Estado autorizam ou perseguem práticas criminosas não por força da lei, mas por interesses privados ${ }^{416}$.

Essas mercadorias políticas podem existir em todos os níveis de poder e são potencialmente negociadas quando uma instituição atua sem muito controle externo, como é o caso das polícias nas ruas. No período aqui estudado, isso parecia evidente ${ }^{417}$. Nos relatos feitos acima, as autoridades policiais - delegado e subdelegado - facilitam a vida de um ou outro preso por razões aparentemente pessoais. Porém, essa informalidade não se restringe ao nível da polícia civil e seus membros. No espaço da soberania, todo mundo pretende mandar.

Ilustrativo é o episódio da prisão e imediata soltura da meretriz identificada como Alice de Tal, citado no capítulo anterior e ocorrido no dia 31 de agosto de 1921. Na noite daquele dia, Alice estava bastante alcoolizada e promovia desordens, quando foi presa por guardas civis e, em seguida, por eles liberada. Alguns praças do Corpo Policial que faziam ronda no local, acharam o comportamento dos Guardas Civis irregular, posto que, a rigor, se prendessem a prostituta, deveriam conduzi-la até a delegacia de polícia. Foi então que os praças decidiram advertir os guardas civis, ocasião em que, um deles, identificado como Guarda 173, teria lhes dito que "procedia como quisesse nas horas de serviço" ${ }^{418}$.

\footnotetext{
${ }^{416}$ MISSE, Michel. Rio como um bazar: a conversão da ilegalidade em mercadoria política. Insight inteligência, v.3, n. 5, p. 12-16, 2002.

${ }^{417}$ Para Zaffaroni, essas relações extorsivas e corruptas entre agentes do estado e atividades ilícitas é uma marca dos sistemas penais latinoamericanos. ZAFFARONI, Eugenio Raúl. Em busca das penas perdidas: a perda da legitimidade do sistema penal. Rio de Janeiro: Revan, 1991, p. 29.

418 APEJE, Fundo SSP, livro 462. Livro de Ofícios de Delegados e Subdelegados da $1^{\text {a }}$ Delegacia de Polícia. 1921
} 
Ele procederia como quisesse, isso é certo; mas os praças pensavam exatamente o mesmo. O conflito seria inevitável e é outro aspecto importante da soberania policial, como destacarei a seguir.

O caso foi apurado pelo Delegado, que convocou o Guarda Civil 173, identificado como Manoel B. da Silva e um dos praças, o auxiliar de alçada Manoel Victor. Segundo Manoel Victor, o guarda civil teria relaxado a prisão da meretriz Alice de Tal a fim de satisfazer o pedido de um sargento do exército conhecido como "Bexiga", amante da citada mulher. Já o guarda civil argumentou ter simplesmente levado a meretriz para a casa dela, localizada na praça da independência. Tudo isso foi comunicado à Chefia de Polícia e não há mais informações sobre o desfecho.

Não é possível conhecer a verdade desses fatos. Porém, a narrativa deles não remete a alguns elementos da realidade policial que pareciam constituir o cotidiano daquelas forças: policiais que se sentiam donos das ruas, serviços prestados pela polícia a membros das forças armadas e disputas entre as diferentes organizações.

Esses acordos, negociações e "jeitinhos" constituíam o cotidiano das forças policiais. Como já dito, soberania implica um poder de decisão sobre o que fazer, o que inclui não apenas o encaminhamento formal do caso penal, mas a sua resolução ali, na instância policial, na informalidade.

No capítulo 2, mencionei como essa informalidade era uma característica das forças policiais brasileiras, marcadas, no período, pelo baixo profissionalismo e a completa confusão entre as esferas pública e privada. Uma confusão, aliás, que não era apenas de policiais, mas também de cidadãos, que viam na polícia uma instância para resolver qualquer tipo de conflito que os acometesse.

A polícia operava com um duplo padrão de ilegalidade: fazer favor e reprimir com truculência. Favor e violência são marcas das interações entre brancos e negros e homens livres e proprietários na ordem escravocrata e, por certo, uma das formas de sociabilidade na sociedade brasileira. Esse padrão que se espraia pelas organizações burocráticas inspirou vastamente a teoria social brasileira, para quem o Brasil esteve sempre entre o "código burocrático" e o "código das relações", como menciona Da Matta ${ }^{419}$ ou mediando as suas relações sociais com figuras como o homem cordial, de Sérgio Buarque de Holanda. No “código das relações", algumas autoridades emergem, longe do domínio da lei e próximas ao domínio pessoal. Oliveira destaca:

\footnotetext{
${ }^{419}$ DA MATTA, Roberto. Carnavais, malandros e heróis: para uma sociologia do dilema brasileiro. $6^{\text {a }}$ ed. Rio de Janeiro: Rocco, 1997, p. 218.
} 
Estamos a um passo do velho "patrimonialismo" voraz com que as classes dominantes brasileiras sempre usaram a coisa pública quando a ela acedem e dela se apropriam. Daí a vigência, entre nós, de brocardos literariamente deliciosos, mas politicamente perversos, como o conhecido "para os amigos, tudo; para os inimigos, a lei”. O qual, aliás, admite uma variação ainda mais perversa: "para os inimigos, nem a lei! ${ }^{420}$.

Aos inimigos, nem a lei. E era essa a "norma" das ruas e mucambos.

\subsubsection{Conflitos entre policiais e militares}

Abordando o conflito vivenciado entre o guarda civil e o membro do Corpo Policial, afirmei que, além das negociações e acordos, o território da rua, livre de constrições legais e judiciais, era disputado por diferentes forças policiais. No caso antes citado, da prisão da prostituta Alice de Tal, o guarda civil fez questão de dizer que fazia o que queria em seu horário de serviço o que, por certo, era também a pretensão dos praças.

Em outra ocasião, a situação quase parecia se repetir, mas agora em sentido inverso. No dia 14 de outubro de 1921, na Rua das Trincheiras, a “decahida” Josepha da Silva foi presa pelo guarda civil de n. 305 por ter, supostamente, pilheriado outro guarda civil, de n. 369. Encaminhada à delegacia de Santo Antonio, o subdelegado se negou a mantê-la presa, dizendo que só o faria por ordem do $1^{\circ}$ delegado ou do Chefe de polícia, não tendo a Guarda Civil esse tipo de autoridade. O caso acabou dando em uma confusão reportada à Chefia de Polícia. As providências, entretanto, tomadas por este, não constam nos arquivos ${ }^{421}$.

Ainda no mesmo ano e mês, no dia 17, o subdelegado de Santo Antonio teria deslocado um guarda civil de um ponto para outro, e esse guarda, ao chegar ao novo local de trabalho, teria sido dispensado por outro guarda civil que lhe disse que o subdelegado não teria autoridade para fazer esse tipo de deslocamento ${ }^{422}$.

Essas pendengas se davam não apenas entre policiais, mas também envolvia estes e militares das forças armadas, sobretudo marinheiros e soldados do exército. Se a rua era um território livre, todas as autoridades se sentiam reis. Eram muitos os episódios.

\footnotetext{
${ }^{420}$ OLIVEIRA, Luciano. O que todo estudante de direito deve ler para conhecer o Brasil: contribuição de um professor de sociologia jurídica. Anuário dos Cursos de Pós-Graduação em Direito (UFPE), v. 18, p. 57-97, 2008, p. 83.

421 APEJE, Fundo SSP, livro 462. Livro de Ofícios de Delegados e Subdelegados da $1^{\text {a }}$ Delegacia de Polícia. 1921.

422 APEJE, Fundo SSP, livro 462. Livro de Ofícios de Delegados e Subdelegados da $1^{\text {a }}$ Delegacia de Polícia. 1921.
} 
Em 2 de julho de 2018, um ofício encaminhado ao delegado pelo subdelegado Felippe d'Albuquerque informou que, naquele dia, um praça de sentinela que se encontrava em frente aos correios teria sido apedrejado e vaiado por indivíduos que o praça disse serem marinheiros nacionais ${ }^{423}$.

Já em 8 de fevereiro de 1922, o delegado Aphulcro de Assumpção encaminhou à Chefia de Polícia um ofício informando que membros do exército estariam nas ruas fazendo desordens e mostrando armas, no que foram advertidos por agentes de polícia e guardas civis. Porém, os militares, insatisfeitos com a repreensão, teriam provocando esses últimos. O delegado ainda informa que não foi a primeira vez que isso ocorreu e pediu providências ${ }^{424}$.

Noutro caso, o conflito teve um desfecho ainda mais trágico. Em 11 de maio de 1915, um confronto envolveu policiais e membros do exército, resultando na morte de um policial, um soldado de nome Luiz Firmino da Silva e em ferimentos graves em Alfredo Pereira dos Santos. Ao final, o delegado informa que foi preso o oficial 49 , do batalhão de caçadores ${ }^{425}$.

Esses conflitos foram também observados por Clarissa Nunes Maia, quando trabalhou com as forças policiais no Recife de 1865 a 1915. Para ela, haveria algumas explicações para isso. Destaco algumas: primeiramente, a baixa remuneração dos policiais e militares, que acabava facilitando o envolvimento deles em casos de corrupção e outros crimes, além da já mencionada, no segundo capítulo, confusão entre patrimônio público e privado típico da formação burocrática brasileira. Também a subordinação política dessas forças fazia refletir nas ruas disputas a nível governamental e partidário ${ }^{426}$. Além de tudo isso, como dito acima, havia a inevitável disputa por poder em um território vazio de uma autoridade central.

\subsubsection{Prisões correcionais, prisões para averiguação e varejamentos: os métodos de uma polícia soberana}

Por fim, algumas notas sobre as prisões para averiguação e os varejamentos domiciliares é fundamental. Eu já falei bastante sobre as prisões correcionais, prática cotidiana da polícia pernambucana e de outros estados, mas não prevista em lei.

Em relação às prisões, a Constituição de 1891 possuía a seguinte previsão:

\footnotetext{
423 APEJE, Fundo SSP, livro 459. Livro de Ofícios de Delegados e Subdelegados da $1^{\text {a }}$ Delegacia de Polícia. 1918.

${ }^{424}$ APEJE, Fundo SSP, livro 468. Livro de Ofícios de Delegados e Subdelegados da $1^{\text {a }}$ Delegacia de Polícia. 1922.

${ }^{425}$ APEJE, Fundo SSP, livro 455, Livro de Ofícios de Delegados e Subdelegados da $1^{\text {a }}$ Delegacia de Polícia, 1915.

${ }^{426}$ MAIA, Clarissa Nunes. Policiados: controle e disciplina das classes populares na cidade do Recife, $1865-$ 1915. 252 f. Tese (Doutorado em História) - Universidade Federal de Pernambuco, Recife, 2001, p. 140 e 143.
} 
Art. 72. A Constituição assegura a brazileiros e a estrangeiros residentes no paiz a inviolabilidade dos direitos concernentes á liberdade, á segurança individual e á propriedade nos termos seguintes:

$\S 13$. A' excepção do flagrante delicto, a prisão não poderá executar-se, sinão depois de pronuncia do indiciado, salvos os casos determinados em lei, e mediante ordem escripta da autoridade competente.

A Constituição de 1824 também dispunha nesse mesmo sentido ${ }^{427}$. Já o Código de Processo Criminal de 1832 estabelecia como lícitas a prisão em flagrante ou aquela emanada de ordem judicial, para indiciados por crimes inafiançáveis (artigos 175 e 176), nada mencionando acerca da prisão para averiguação ou da prisão correcional. Sendo assim, só existiam mesmo dois tipos de prisões processuais: o flagrante e a preventiva.

No início do século XX, vigoravam a respeito das regras sobre prisões processuais o Código Criminal do Império de 1832, a lei 2.033 de 1871 e o Decreto 2.110 de 1909.

O flagrante ocorria quando alguém era encontrado praticando um delito, quando tinha acabado de cometê-lo ou quando era perseguido pelo clamor público. Nessas estritas hipóteses, o flagranteado seria encaminhado à autoridade mais próxima, que, segundo a lei 2.033, artigo $12, \S 2^{\circ}$, poderia ser os Chefes de Policia, Juízes de Direito e seus substitutos, Juízes Municipaes e seus substitutos, Juízes de Paz, Delegados e Subdelegados de Policia. Em seguida, a depender do tipo de crime, o preso seria liberado (nos crimes policiais ou contravenções) ou posto sob custódia, por um juiz, para alguns esclarecimentos. Neste sentido era a redação do artigo 133 do Código de Processo Criminal de $1832^{428}$.

Já a prisão preventiva estava justificada em três hipóteses: a) risco de fuga, b) risco de o preso voltar a praticar novos crimes e c) possibilidade de o preso destruir provas e vestígios do delito, e só poderia ser decretada nos seguintes casos, segundo o decreto 2.110 de 1909:

Art. 27. A prisão preventiva é autorizada de accôrdo com a legislação vigente.

$\S 1^{\circ}$ Dos crimes afiançáveis quando se apurar no processo que o indiciado:

a) é vagabundo sem profissão licita e domicilio certo;

já cumpriu pena de prisão por effeito de sentença proferida por tribunal competente.

$\S 2^{\circ}$, Nos crimes inafiançáveis, emquanto não prescreverem, qualquer que seja a época em que se verifiquem indicios vehementes de autoria ou cumplicidade, revogado o $\S 4^{\circ}$ do art. $13^{\circ}$ da lei n. 2.033 , de 20 de setembro

\footnotetext{
427 O artigo Art. 179, inciso X da Carta de 1824 dispunha: “A' excepção de flagrante delicto, a prisão não póde ser executada, senão por ordem escripta da Autoridade legitima. Se esta fôr arbitraria, o Juiz, que a deu, e quem a tiver requerido serão punidos com as penas, que a Lei determinar".

428 Art. 133. Resultando do interrogatorio suspeita contra o conduzido, o Juiz o mandará pôr em custodia em qualquer lugar seguro, que para isso designar; excepto o caso de se poder livrar solto, ou admittir fiança, e elle a dér; e procederá na formação da culpa, observando o que está disposto a este respeito no Capitulo seguinte.
} 
de 1871 e $§ 3^{\circ}$ do art. 29 do decreto n. 4.824 , de 29 de novembro do mesmo anno.

Porém, a prática policial comportava o uso corrente dessas outras formas de detenção: aquela voltada à correção e a destinada à averiguação. Aliás, de tão corrente, o Regulamento da Casa de Detenção do Recife mencionava, em seu artigo $1^{\circ}$, que a unidade se destinava, dentre outros, aos presos para averiguações policiais. Portanto, ocorriam como uma naturalidade quase inquestionável.

Porém, por vezes, essas prisões para averiguação sofreram algum tipo de oposição. João Mendes de Almeida Junior cita, a esse respeito, duas circulares emitidas em 1865 e em $1889^{429}$. Em 2 de janeiro de 1865, o Ministro da Justiça, Francisco José Furtado, publicou uma circular recomendando às autoridades policiais que só prendessem nas hipóteses autorizadas em lei, asseverando que "as prisões pelo motivo vago de - investigações policiais são manifestamente ilegais". Em 1889, o então ministro, Cândido de Oliveira, expede uma circular com teor semelhante, recomendando às autoridades que coíba os abusos "que ainda perduram, de prisões para averiguações policiais".

Também João Evangelista Peixoto Fortuna mencionava a ilegalidade das prisões para averiguação, ao afirmar que "as frequentes prisões que a polícia leva a cabo sob o pretexto de averiguações são actos de arbitrariedade manifesta, nitidamente vedados pela lei, sendo verdadeiro crime contra a liberdade individual" 430 .

Assim, havia entendimentos, na doutrina processual penal brasileira, contestando os abusos e os excessos praticados pela polícia. Inclusive, mencionei, no capítulo 3, a oposição que os liberais faziam a mudanças legislativas tendentes a enfraquecer o habeas corpus ou outros instrumentos de tutela do direito à liberdade. Porém, na prática, as averiguações eram frequentes e tinham como alvos operários organizados e vistos como subversivos, mas também mulheres prostitutas, como o caso de Antonia Barbosa, citado no capítulo anterior. Era, portanto, um instrumento da polícia política e, da polícia ordeira e moral.

Ao mesmo tempo, é curioso que as prisões para averiguação sejam lembradas como abusivas, mas que pouco ou nada se diga a respeito das frequentes prisões correcionais, imperando, neste ponto, o silêncio.

No tocante aos "varejamentos", tecnicamente buscas e apreensões sem mandado, podiam ser autorizados pela autoridade judicial (artigo 192) e também pelos chefes de polícia,

\footnotetext{
${ }^{429}$ ALMEIDA JR, João Mendes de. O processo criminal brazileiro. Vol. I. 3 ed. Rio de Janeiro: Typ. Baptista de Souza, 1920, 317-319.

${ }^{430}$ FORTUNA, João Evangelista Peixoto. Manual de direito processual Criminal. Rio de Janeiro: Typographia Bedeschi, 1915, p. 26.
} 
que, por força de legislações estaduais, tinham essa atribuição. A constituição de 1891 também previa a proteção ao domicílio ao dispor, em seu artigo 72 que:

$\S 11$. A casa é o asylo ínviolavel do individuo; ninguem póde ahi penetrar, de noite, sem consentimento do morador, sinão para acudir a victimas de crimes, ou desastres, nem de dia, sinão nos casos e pela fórma prescriptos na lei.

A respeito dos "varejamentos", quando ocorriam nos chamados "edifícios materiais", eram tidos como permitidos porque bares, tabernas, oficinas, bilhares, estalagens e outros estabelecimentos semelhantes não eram entendidos como 'domicílio'431.

Dessa prerrogativa a polícia pernambucana fazia bastante uso. Em um ofício de 29 de novembro de 1916, o delegado Anulpho Lins e Silva informou ao chefe de polícia que o subdelegado teria dado cumprimento à circular no 17 da chefia, que dava ordens de "varejar" as casas que ele lista, onde havia prática de jogo de bicho ${ }^{432}$. Em 29 de outubro de 1917, o mesmo delegado afirma que, "obedecendo fielmente às ordens do chefe de polícia" teria, em um ano, varejado 50 casas de tavolagem e apreendido 137 roletas $^{433}$.

Só que, em busca da repressão à conduta de jogos ilícitos, a polícia poderia até mesmo vir a varejar residências privadas, sem apresentar mandado judicial e sem justificar o ato. Foi o caso de uma ocorrência que, somente foi relatada no livro de ofícios de delegados e subdelegados de 1919 porque envolveu uma terceira pessoa, o comerciante José Ramos de Oliveira. Em 31 de maio daquele ano, ele encaminhou ao Chefe de polícia um pedido de devolução de cadeiras que seriam suas e que estaria emprestada na casa de um cliente de nome Flávio Aragão que, por sua vez, tivera a sua casa varejada. Em razão de terem sido encontrados, no interior da residência, objetos de jogos ilícitos, a polícia teria apreendido esse bens e outros, incluindo as cadeiras de José Ramos que, agora, as reivindicava ${ }^{434}$.

O requerimento, por certo, não põe em questão o varejamento em si, mas, tãosomente, a legitimidade do comerciante de ter as cadeiras de volta, posto que não era envolvido na prática de jogos.

\footnotetext{
${ }^{431}$ BUENO, José Antonio Pimenta. Apontamentos sobre o processo criminal brazileiro. 3 ed. Rio de Janeiro: H Garnier, Livreiro Editor, 1902, p. 118.

${ }^{432}$ APEJE, Fundo SSP, livro 456, Livro de Ofícios de Delegados e Subdelegados da $1^{a}$ Delegacia de Polícia, 1916.

${ }^{433}$ APEJE, Fundo SSP, livro 458, Livro de Ofícios de Delegados e Subdelegados da $1^{\text {a }}$ Delegacia de Polícia, 1917.

${ }^{434}$ APEJE, Fundo SSP, livro 460. Livro de Ofícios de Delegados e Subdelegados da $1^{a}$ Delegacia de Polícia. 1919.
} 
Em 6 de maio de 1916, por outro lado, o delegado Anulpho Lins e Silva relata à Chefia de Polícia todos os esforços que empreendera para solucionar o caso de assassinato e roubo do comerciante Lindolpho de Andrade Lima, afirmando ter feito "buscas e vistorias" em casas suspeitas, aparentemente sem autorização nem da justiça e nem da Chefia de Polícia $^{435}$.

Ambas as práticas - prisões e varejamentos - não eram propriamente um segredo, como se dá nos dias de hoje. Tampouco são práticas exclusivas de Estados ditatoriais ou totalitários, definidos como Estados de Polícia, embora sejam frequentemente praticadas neles. Foram, ao contrário, parte do cenário democrático brasileiro, recaindo sobre os indivíduos identificados como a desordem social.

Aproveito, então, para fazer uma última reflexão. Em "Do nunca mais ao eterno retorno", Luciano Oliveira aborda o tema da tortura realizada por agentes públicos e lembra ao leitor do passado colonial no Brasil e da existência generalizada dessa técnica ao longo de todo o século XIX e XX, incluindo, também, as ditaduras pelas quais o país passou. O pau-dearara, tão conhecido do regime militar brasileiro, lembra o autor, "já era utilizado pelos senhores de escravos para imobilizá-los, como se pode ver em gravuras de Jean-Baptiste Debret" ${ }^{\prime 36}$.

Porém, a problematização sobre a tortura passou a compor as páginas de tratados de direitos humanos ou o pensamento crítico apenas quando essa violência se deslocou das classes tradicionais dos torturáveis - pretos e pobres - e atingiu a classe média branca politizada, como os estudantes, os jornalistas, os intelectuais e outros opositores políticos perseguidos por aqueles regimes.

Desse modo, para o autor, avançar na compreensão das práticas autoritárias das agências de controle penal no Brasil pressupõe superar a ideia de que elas são - apenas - uma "herança maldita" ${ }^{437}$ da Ditadura Militar, posto que, se nesse período se pode identificar uma série de retrocessos em termos de censura e cassação de direitos, o Brasil vem, há muito mais tempo, acumulando práticas institucionais violentas.

Enfim, procurei, neste capítulo, enfrentar o descompasso entre as práticas policiais e os discursos disciplinares, presentes nos textos e discursos policiais, de juristas, de médicos e

\footnotetext{
${ }^{435}$ APEJE, Fundo SSP, livro 457, Livro de Ofícios de Delegados e Subdelegados da $1^{\text {a }}$ Delegacia de Polícia, 1916.

${ }^{436}$ OLIVEIRA, Luciano. Do nunca mais ao eterno retorno. Uma reflexão sobre a tortura. São Paulo: Brasiliense, 2009 , p. 27.

${ }^{437}$ OLIVEIRA, Luciano. De Rubens Paiva a Amarildo. E "Nego Sete"? O regime militar e as violações de direitos humanos no Brasil. 2016. MIMEO.
} 
de criminólogos. O sonho disciplinar freava na soberania policial, não anunciada, mas amplamente praticada.

Sendo assim, a realidade cotidiana dos contraventores e desordeiros das cidades era a de serem identificados por esses saberes como a imagem do crime ou criminosos em si, mas, por outro lado, ao invés de ser a eles dispensado o tratamento, a cura, a ortopedia e a disciplina, as práticas se mantinham no nível da relação com o corpo, controlando a circulação destes e infligindo dor como mecanismo de repressão.

Como dito, era a conjugação perfeita do patrimonialismo e do racismo, a faceta da sociedade escravocrata que pareceu não abandonar as relações sociais no Brasil, tampouco o seu sistema punitivo na primeira república e, quiçá, até os dias de hoje. 


\section{CONSIDERAÇÕES FINAIS}

As forças policiais surgiram, no Brasil, no século XIX, no contexto da escravidão, um regime econômico, político e social que moldou as relações sociais no país e as instituições do próprio Estado. Naquele momento, apesar das diversas forças, algumas vinculadas ao Império e outras às autoridades locais, notadamente os proprietários de terras e escravos, as polícias perseguiam, principalmente, negros fugidos ou ex-escravos, muitos dos quais acusados de pequenas ilegalidades como vadiagem, embriaguez, mendicância, além da fuga.

A tarefa primordial dessas polícias - controlar a circulação de negros - ligou-se ao modo como o faziam. Capturar, açoitar, flagelar o corpo: a gramática da escravidão se reproduzia nas chicotadas do Major Vidigal e dos agentes policiais.

As leis penais e processuais penais, por sua vez, respondiam à síndrome do medo a que se refere Clóvis Moura e tipificava condutas e modificavam procedimentos e atribuições das forças policiais buscando sanar a ameaça da onda negra.

Com a chegada da República, as forças policiais foram descentralizadas e organizadas em cada um dos estados. Problemas antigos permaneceram: baixa profissionalização dos agentes, baixos salários, confusão entre o patrimônio público e privado e uma tendência contemplar interesses particulares em detrimento do público. Era o patrimonialismo típico das burocracias brasileiras; aliado a ele, a violência da escravidão. $\mathrm{O}$ medo do negro continuou a permear no período, refletindo diretamente na programação criminalizante do país.

Nas ruas das cidades, no início da República, a tônica do discurso oficial do Estado e das polícias era "ordem e progresso". Bairros bonitos, cidade higienizada. A desordem de todo tipo precisava ser contida e as ruas e os mucambos se tornaram o império da polícia, a organização estatal devotada à manutenção da segurança pública.

A soberania policial foi a experiência que se consolidou nesses espaços e muitos fatores contribuíram para isso. Primeiramente, o fato de esse espaço da soberania ser o das pessoas identificadas com o perigo, descritas pelo racismo como menos humanas, fator que naturaliza a supressão de direitos. Talvez aqui valha a pena rememorar o Serviço de Locação de Domésticos e a sua violência brutal de submeter trabalhadoras domésticas a uma inspeção de saúde e a um registro policial porque, a priori, seriam sujas, doentes e potencialmente criminosas. A soberania não existia para outras categorias de trabalho, mesmo o feminino. Portanto, a soberania policial é uma expressão do racismo.

Outro fator foi a falta de uma estrutura burocrática e jurídica de controle sistemático da atividade policial, a qual permanecia ocorrendo à revelia de qualquer limite, salvo nos 
casos - minoritários - em que os sujeitos atingidos por essas violações recorriam à justiça, impetravam habeas corpus ou outras ações de liberdade.

Porém, quando se verificou mães de presos e presos recorrendo à Chefia de Polícia para conseguir a liberdade, tem-se uma imagem do fosso que separava essa parcela da população do acesso à justiça, o que, inclusive, como também destaquei, contribuía para que as delegacias representassem uma via importante de resolução dos mais diversos tipos de conflitos.

Neste cenário, a criminalização das contravenções foi também uma chave fundamental para essa soberania. Primeiro porque, em desrespeito à legalidade, essas condutas eram descritas de forma amplíssima nos códigos, deixando às autoridades liberdade para nelas encaixar qualquer situação. A tal ponto que a polícia prendia por as pessoas situações, a priori, atípicas como gatunagem, desordem, pederastia... Afinal, o que estava em jogo não era reprimir condutas, mas determinados sujeitos. Era a expressão do velho direito penal do autor.

Ainda, no campo processual penal, o silêncio sobre parte da atividade policial deixou todas essas questões de lado e, ao mesmo tempo, em relação às contravenções, tinha-se uma crença de que, por constituírem infrações de menor gravidade, não demandariam o rígido e burocrático processo penal. Nessa toada, era os desordeiros da cidade presos e condenados sem processo, na instância policial.

Essa instância policial possui sua própria regra, seus próprios códigos, os quais são mediados apenas indiretamente pelo direito. Assim, destaquei situações em que guardas civis, praças, soldados, delegados, subdelegados e, finalmente, chefes de polícia decidiam se prendiam ou soltavam prostitutas, não em virtude da lei, mas para prestar favores ou por outras razões de ordem pessoal; espancavam quando julgavam imprescindível à manutenção de suas autoridades; toleravam mais ou menos o jogo do bicho por razões não expressas; beneficiavam presos quando eram amigos seus ou de seus familiares; Investigavam crimes com instrumentos legais e, às vezes, além ou contra eles; averiguaram as vidas dos sujeitos ameaçadores; varejaram residências sem qualquer critério; vigiavam organizações operárias; infiltraram agentes; tomavam partido em greves; davam sermão em donos de jornais, apostando que eles ajustassem o conteúdo de algumas publicações; inspecionaram empregadas domésticas com o intuito de manter seguros os lares das famílias brancas. Enfim, policiais procediam como queriam na hora do serviço deles.

A utopia disciplinar partilhada, no período, por policiais, juristas, médicos e criminólogos e esboçada no desejo de ver todos esses desordeiros se tornando corpos politicamente dóceis e economicamente úteis por certo não se realizou. Porém, outra utopia 
parece ter se concretizado plenamente: a das vidas policiadas. Moradores dos bairros negros e pobres do Recife conviveram cotidianamente com a presença da polícia; a presença desejada, que resolvia seus conflitos e a presença indesejada, que os subjugava com violência. Como uma justiça de primeira instância, sem código, sem princípios, sem processo, a polícia reinou soberanamente, sofrendo pouco ou nenhum constrangimento de outros órgãos do Estado.

Falei pouco sobre os espaços de resistência, embora saiba que eles existiam. No Recife, talvez o fato de as bandas de frevo serem aquarteladas e os seus desfiles sofrerem repressão policial por conta da presença dos capoeiras seja a face desse imbróglio não disciplinar. Mas, ao fim e ao cabo, eram vidas policiadas.

O campo jurídico conviveu com essa realidade de forma mais ou menos silente. $\mathrm{Na}$ estrutura legal, a presença policial foi resolvida pela trinca desordem-contravenção-polícia. Ou seja, era preciso manter a ordem e os sujeitos que a ameaçavam eram basicamente os contraventores. Estes últimos, praticando infrações de menor complexidade, não precisariam ser levados a longos processos judiciais, reservando-se a eles os procedimentos mais simples. Isso era a teoria. Na prática, os juízos de contravenção - uma espécie de protótipo dos juizados especiais criminais - não existiram em todas as cidades e a instância a que coube lidar com os contraventores foi a policial.

No Recife, esse era o nosso quadro. $\mathrm{O}$ que chegava à polícia e o que efetivamente se transformava em inquérito e em processo judicial eram realidades bem distintas. A imagem do funil, com a qual se trabalham sobre cifras ocultas na criminologia, é ideal para pensar essa dinâmica.

Isso ocorria sem impactar a doutrina ou os debates jurídicos de maneira significativa. Os manuais de processo penal anunciavam princípios liberais, materializavam as garantias contidas nas constituições, mas nunca ou poucas vezes, atentava para essa outra justiça que se realizava nas ruas brasileiras.

Quando policiais se sentem, e efetivamente são, juízes de primeira instância, desligados dos constrangimentos da lei, permitem-se fazer qualquer coisa. A soberania policial pode apresentar-se com muitas faces, inclusive, aquela da truculência, da violência mais crua. A soberania policial no início do século $\mathrm{XX}$ é a reatualização dos termos da sociedade escravocrata: favor e violência.

Nesse trabalho, procurei construir esses argumentos recuperando narrativas de ocorrências policiais, discursos científicos produzidos por essas forças, doutrinas jurídicas e o percurso histórico das legislações penal e processual penal brasileiras. Aqui, acabei por privilegiar, como já disse, as vozes oficiais. 
É, portanto, apenas um olhar. Uma leitura parcial de um fenômeno que, por certo, existe, mas cuja complexidade não permitiu que eu o esgotasse. Como disse na introdução, esgotar não é, jamais, uma possibilidade, e os limites de uma tese ou qualquer outra produção são, eles próprios, a certeza de que a academia e o seu conhecimento não se fazem sozinhos e que, para além da academia, há saberes valiosos que ajudam a entender o mundo.

Espero com esse texto lançar mais perguntas do que respostas e, acima de tudo, provocar à compreensão de um fenômeno tão evidente quanto difícil de destrinchar. Desse modo, lanço alguns questionamentos que foram surgindo ao longo da pesquisa.

Uma interessante agenda acerca da temática seria pensar o problema em termos comparativos com outras realidades nacionais. Afinal, a polícia soberana é uma exclusividade da sociedade brasileira? Quais os espaços de soberania dessas forças em outros países? Quais os traços que particularizam a experiência no Brasil?

Muito se fala a respeito da existência de um Estado Policial como aquele em que essas forças policiais, ligadas à hipertrofia do executivo, comandam a vida social de maneira mais alastrada? Em que medida o Estado Policial se diferencia ou se assemelha ao fenômeno descrito nesta tese?

Inclusive, uma década após o período por mim estudado, o Brasil atravessou na política um momento de profundo autoritarismo, com a consagração, na ditadura do Estado Novo, de técnicas e premissas verdadeiramente de defesa social, fazendo cair por terra, inclusive nos textos jurídicos, as garantias liberais. Aquele momento alterou as práticas policiais? Em termos de soberania policial, o que teria se configurado de modo diferente?

Quais os espaços da soberania policial hoje? Eu iniciei este trabalho falando de um caso ocorrido com P., em 2006. Depois mencionei a experiência de Higor com o flagrante forjado. Diariamente, movimentos sociais, sobretudo os movimentos negros, vêm denunciando a violência cotidiana a que muitos estão submetidos, desde abordagens arbitrárias aos assassinatos em ato de pura execução. Em 2017, os casos de mortes em intervenções policiais cresceu 70\%. Amarildo, Herinaldo Vinícius de Santana, Mateus Alves dos Santos, Vinícius de Santana, são tantos os nomes que poderiam ser listados, de jovens, "quase todos pretos ou quase pretos de tão pobres" mortos em situações que, sequer, chegam a se transformar em processos judiciais porque os inquéritos são arquivados ${ }^{438}$. Entender essa soberania policial não seria uma premissa para se evitar essas mortes?

${ }^{438}$ Em pesquisa recente, o delegado de polícia do Rio de Janeiro Orlando Zaccone verificou que inquéritos policiais que investigam mortes de civis promovidas por policiais militares naquela cidade são arquivados indiscriminadamente, sob a justificativa de o crime ter se perpetrado em legítima defesa. ZACCONE, Orlando. 
Outra pergunta possível diz respeito à perda da centralidade das contravenções na gestão dos bairros negros e pobres. De fato, embora a Lei 9.099 de 1995 tenha permitido a reabilitação de processos por vias de fato, perturbação de sossego, desacatos, injúrias e outros imbróglios que eram antes esquecidos nas superlotadas varas criminais, o fato é que a gestão da miséria hoje se dá por outra lei, a 11.343 de 2006, a lei de drogas. No Brasil, os índices de encarceramento provisório por tráfico são alarmantes e o processo de criminalização - da abordagem às apreensões (ou aos forjados), das investigações ao processamento e à condenação - tem absoluta centralidade das figuras policiais. Afinal, são policiais militares que decidem quem é suspeito, que entra em residências sem mandado judicial, que encaminham esses frágeis elementos a delegacias de polícia e que servem de testemunhas ao longo dos processos. Seria essa a atualização da soberania policial?

Ainda, durante o doutorado surgiram, no Brasil as audiências de custódia, importante instrumento de controle da atividade policial. Porém, como indicam as pesquisas mais recentes $^{439}$, a tortura reportada pelos presos ou visível em seus corpos muitas vezes é vista com conivência pelo Ministério Público, pelo Judiciário e pela Defensoria Pública. O que se dá do lado de lá das ruas - o espaço da polícia - parece ainda não preocupar aquelas instituições ${ }^{440}$.

Por fim, conhecer e reconhecer a história e saber qual o papel de nós, juristas, na formação e conformação de modelos de atuação policial, foi uma das pretensões desta tese. Durante o doutorado, saí da condição de ex-aluna para a de professora da FDR, a escola que abrigou praticamente todos aqueles homens brancos que dinamizaram a atuação policial no Recife e que construiu saberes que acabaram por ser tão úteis à atuação soberana da polícia, como dito. Isso de alguma forma me traz um pouco de angústia e amplia a minha responsabilidade como docente, porque, de certa maneira, a vontade é de poder fazer diferente. A tradicional casa de Tobias poderá ser a casa de outras e de outros nomes. Quem sabe a casa de Robeyoncé, a primeira advogada trans e negra de Pernambuco, formada na FDR em 2016... Ventos novos nessa grande caminhada? Espero que sim.

Indignos de vida: a forma jurídica da política de extermínio de inimigos na cidade do Rio de Janeiro, 2015, p. 159.

${ }^{439}$ INSTITUTO DE DEFESA DO DIREITO DE DEFESA. Audiências de custódia: panorama nacional. 2017. Disponível em: < http://www.iddd.org.br/wp-content/uploads/2017/12/Audiencias-de-Custodia_PanoramaNacional_Relatorio.pdf $>$ Acesso em $28 \mathrm{dez} 2017$.

${ }^{440}$ Em uma pesquisa publicada recentemente, o Conectas demonstra como, em São Paulo, os casos de tortura e outros tratamentos cruéis e degradantes não merecem a atenção do poder judiciário, do Ministério Público. CONECTAS DIREITOS HUMANOS. Tortura Blindada: Como as instituições do sistema de Justiça perpetuam a violência nas audiências de custódia. 1a ed. São Paulo, 2017. Disponível em: <http://www.conectas.org/arquivos/editor/files/Relato\%CC\%81rio\%20completo_Tortura\%20

blindada_Conectas\%20Direitos\%20Humanos(1).pdf>. Acesso em $20 \mathrm{dez} 2017$. 


\section{REFERÊNCIAS}

AGAMBEN, Giorgio. Homo sacer: O poder soberano e a vida nua. Belo Horizonte: Editora UFMG, 2014.

AGAMBEN, Giorgio. Meios sem fim: notas sobre política. Belo Horizonte: Autêntica Editora, 2015.

ALBERNAZ, Elizabete. "Faro Policial": um estudo de caso acerca dos critérios de construção e operação de padrões de suspeição e seletividade na ação policial. $39^{\circ}$ Encontro Anual da Anpocs, Caxambu, 2015.

ALBUQUERQUE NETO, Flávio de Sá C. Da cadeia à Casa de Detenção: a reforma prisional no Recife em meados do século XIX. MAIA, C. N.; SÁ NETO, F. de; COSTA, M.; BRETAS, M. L. (orgs) História das prisões no Brasil. Volume II. Rio de Janeiro: Rocco, 2009.

ALMEIDA JR, João Mendes de. O processo criminal brazileiro. Vol. I. 3 ed. Rio de Janeiro: Typ. Baptista de Souza, 1920.

ALMEIDA, Manuel Antonio de. Memórias de um sargento de milícias. São Paulo: Editora Ática, 1998.

ALVAREZ, Marcos César. Bachareis, criminologistas e juristas: saber jurídico e Nova Escola Penal no Brasil. São Paulo: IBCCRIM, 2003.

ANDRADE, Vera R. P. de; MAYOARA, Marcelo; GARCIA, Mariana D. de O. O controle penal na sociedade escravocrata: contributo da economia política da pena para a compreensão da brasilidade. Discursos sediciosos: crime, direito e sociedade. Ano 20, números 23/24, p. $162-178,2016$

ANITUA, Gabriel Ignacio. Histórias dos pensamentos criminológicos. Rio de Janeiro: Revan, 2008.

ANIYAR DE CASTRO, Lola. Criminologia da libertação. Rio de Janeiro: Revan, 2005.

ARAÚJO, Higor Alexandre Alves de. Culpados, mesmo com prova em contrário: uma análise jurisprudencial da alegação de flagrante forjado em prisões por tráfico de drogas no Tribunal de Justiça de Pernambuco. Trabalho de Conclusão de Curso. Faculdade de Direito do Recife-UFPE, 2017.

ARAÚJO, João Vieira de. Codigo Penal commentado theorica e praticamente. Rio de Janeiro, São Paulo: LAEMMERT \& C. Editores, 1896.

AZEVEDO, Célia Maria Marinho de. Onda negra, medo branco: o negro no imaginário das elites do século XIX. 3 ed. São Paulo: Annablume, 2004.

BARATTA, Alessandro. Direitos humanos: entre a violência estrutural e a violência penal. Fascículos de Ciências Penais. Ano 6, v. 6, n.2, p. 44-63, 1993. 
BARATTA, Alessandro: Criminologia Crítica e Crítica do Direito Penal: Introdução à Sociologia do Direito Penal. 3 ed. Rio de Janeiro: Editora Revan: Insitutito Carioca de criminologia, 2002.

BARROS FILHO, José. Criminologia e modos de controle social. No Maranhão no início do século XX. São Luís: FAPEMA, 2013.

BARROS, José D’Assunção. A construção social da cor: diferença e desigualdade na formação da sociedade brasileira. Petrópolis: Editora Vozes, 2014.

BARROS, José d’Assunção. Fontes históricas. Revista de História, Campo Grande, v.2, n. 3, p. 71-115, jan/jun, 2010.

BARROS, Marcelo. Polícia e tortura no Brasil: conhecendo a caixa das maçãs podres. Curitiba: Appris, 2015.

BATISTA, Nilo. Apontamentos para uma história da legislação penal brasileira. Rio de Janeiro: Revan, 2016.

BATISTA, Nilo. Pena pública y esclavismo. Coleccion Intercambios. Caracas: Universidad Nacional Experimental de la Seguridad, 2012.

BATISTA, Vera M. O medo na cidade do Rio de Janeiro: dois tempos de uma história. Rio de Janeiro: Editora Revan, 2003.

BECKER, Howard. Outsiders. Rio de Janeiro: Jorge Zahar Editor, 2008.

BECKER, Howard. Segredos e truques da pesquisa. Rio de Janeiro: Jorge Zahar Editor, 2007.

BENJAMIN, Walter. Escritos sobre mito e linguagem. São Paulo: Duas Cidades; Editora 34, 2011.

BERGSMANN, Ilene R. The forgotten few: Juvenile female offenders. Federal Probation, 53(1), p. 73-78, 1989.

BERTÚLIO, Dora Lúcia. Direito e relações raciais: uma introdução crítica ao racismo. Dissertação de mestrado. Programa de Pós-Graduação em Direito. UFSC. 1989.

BEVILAQUA, Clóvis. Criminologia e direito. Salvador: Livraria Magalhães, 1896.

BOURDIEU, Pierre. Esprits d'État: génese et structure du champ bureaucratique. Actes de la recherche en sciences social, vol. 96-97, p. 49-62, mar 1993. Disponível em < http://www.persee.fr/web/revues/home/prescript/article/arss_0335-

5322_1993_num_96_1_3040>.

BOURDIEU, Pierre. O poder simbólico. 15ª ed. Rio de Janeiro: Bertrand Brasil, 2011.

BRETAS, M. L.; ROSENBERG, A. A história da polícia no Brasil: balanços e perspectivas. Topoi, vol. 14, n. 26, jan/jul, p. 162-173, 2013.

BRETAS, Marcos Luiz. A queda do império da navalha e da rasteira (a República e os capoeiras). Estudos Afro-Asiáticos. Junho, p. 239-256, 1991. 
BRETAS, Marcos Luiz. O informal no formal: a justiça nas delegacias cariocas da República Velha. Discursos sediciosos. Rio de Janeiro: Instituto Carioca de Criminologia, ano 1, número 2, $2^{\circ}$ semestre, 1996.

BRETAS, Marcos Luiz. Ordem na cidade: o exercício cotidiano da autoridade policial no Rio de Janeiro: 1907-1930. Rio de Janeiro: Rocco, 1997.

BRETAS, Marcos Luiz. Revista Policial: formas de divulgação das polícias no Rio de Janeiro de 1903. História Social, n. 16, primeiro semestre de 2009.

BUENO, José Antonio Pimenta. Apontamentos sobre o processo criminal brazileiro. 3 ed. Rio de Janeiro: H Garnier, Livreiro Editor, 1902.

CÂMARA DOS DEPUTADOS. Anais. Tomos I e II. 1888.

CANO, Ignácio. Controle de polícia no Brasil.. Haia: Altus, 2005. Disponível em: <www.soudapaz.org/upload/pdf/textocanoppc.pdf>.

CARNEIRO, Sueli. Enegrecer o feminismo: a situação da mulher negra na América Latina a partir de uma perspectiva de gênero. Disponível em < https://www.geledes.org.br/enegrecero-feminismo-situacao-da-mulher-negra-na-america-latina-partir-de-uma-perspectiva-degenero/>.

CARVALHO, José Murilo de. Cidadania no Brasil: o longo caminho. Rio de Janeiro: Civilização Brasileira, 2015.

CASTRO, Augusto Olympio Viveiros de. These VI. Seção II. Annaes da Conferência Judiciária-Policial de 1917. Vol. 1. Rio de Janeiro: Imprensa Nacional, 1918.

CASTRO, Lola Aniyar. Criminologia da libertação. Rio de Janeiro: Revan, 2005.

CAULFIELD, Sueann. Em defesa da honra: modernidade, moralidade e nação no Rio de Janeiro (1918-1940). Campinas: Editora Unicamp, 2000.

CHALHOUB, Sidney. Medo branco de almas negras: escravos, libertos e republicanos na cidade do Rio de Janeiro. Revista Brasileira de História. V. 8, n. 16, p. 83-105, mar/ago, 1988.

CHÂTELET, François; DUHAMEL, Olivier; PISIER-KOUCHNER, Evelyne. História das ideias políticas. Rio de Janeiro: Zahar, 2009.

CHAVES, João. O problema do direito em Michel Foucault. Curitiba: Juruá, 2010.

CONECTAS DIREITOS HUMANOS. Tortura Blindada: Como as instituições do sistema de Justiça perpetuam a violência nas audiências de custódia. 1a ed. São Paulo, 2017. Disponível em:

http://www.conectas.org/arquivos/editor/files/Relato\%CC\%81rio\%20completo_Tortura\%20b lindada_Conectas\%20Direitos\%20Humanos(1).pdf

CORREIA, Mariza. Repensando a família patriarcal brasileira. Cadernos de Pesquisa, São Paulo, n. 37, p. 5-16, mai, 1981. 
COUCEIRO, Silvia. Artes de viver a cidade: conflitos e convivências nos espaços de diversão e prazer do Recife nos anos 1920. Tese de doutorado. Programa de Pós-Graduação em História da UFPE, 2003.

DAVIS, Angela. Are prisons obsolete ? New York : Seven Stories Press, 2003.

DEL OLMO, Rosa. A América Latina e sua criminologia. Rio de Janeiro: Revan, 2004.

DUARTE, Evandro Charles Piza. Criminologia e racismo. 1 ed. Curitiba: Juruá, 2011.

DUARTE, Evandro Charles Piza. Paradigmas em criminologia e relações raciais. Caderno CEAS, Salvador, n. 238, p. 500-525, 2016.

DUARTE, Evandro P; QUEIROZ, Marcos V. L.; COSTA, Pedro A. A hipótese colonial, um diálogo com Michel Foucault: a modernidade e o Atlântico Negro no centro do debate sobre racismo e sistema penal. Universitas JUS, volume 27, n. 2, p. 1-31, 2016.

DUARTE, Ruy. História Social do frevo. Rio de Janeiro: Editora Leitura S.A., 1968.

DUSSEL, Enrique. 1492: o encobrimento do outro (A origem do "mito da modernidade). Tradução: Jaime A. Clasen. Petrópolis: Vozes, 1993.

EWALD, François. Foucault, a norma e o direito. 2 ed. Lisboa: Vega, 2000.

FAORO, Raimundo. Os donos do poder: formação do patronato político brasileiro. 5 ed. São Paulo: Globo, 2012.

FARIA, Thaís Dumêt. Memória de um silêncio eloquente: a criminalização das mulheres no Brasil na primeira metade do século XX. 2013. 203 f., il. Tese (Doutorado em Direito) Universidade de Brasília, Brasília, 2013.

FAUSTO, Boris. Crime e cotidiano: a criminalidade em São Paulo (1880-1924). 2 ed. São Paulo: EDUSP, 2001.

FAUSTO, Boris. Trabalho urbano e conflito social (1890-1920). São Paulo, Rio de Janeiro: DIFEL, 1976.

FERREIRA, Jonatas; HAMLIN, Cynthia. Mulheres, negros e outros monstros. Estudos Feministas, Florianópolis, 18(3), p. 811-836, set/dez, 2010.

FERRI, Enrico. [1910] Estudios de antropologia criminal. 3 ed. Madrid: La España Moderna, Colección de libros escogidos.

FIGUEIREDO, José Burle de. A contravenção de vadiagem. Rio de Janeiro: Jacintho Ribeiro dos Santos Editor, 1924.

FLAUZINA, Ana Luiza Pinheiro. O feminicídio e os embates das trincheiras feministas. Discursos sediciosos: crime, direito e sociedade. Ano 20, números 23/24, p. 95-106, 2016.

FONSECA, Márcio Alves da. Michel Foucault e o direito. São Paulo: Saraiva, 2014.

FORTUNA, João Evangelista Peixoto. Manual de direito processual Criminal. Rio de Janeiro: Typographia Bedeschi, 1915. 
FOUCAULT, Michel. A verdade e as formas jurídicas. Rio de Janeiro: Nau Editora, 2009.

FOUCAULT, Michel. Em defesa da sociedade. São Paulo: Martins Fontes, 2005.

FOUCAULT, Michel. La société punitive. Cours au Collège de France. 1972-1973. Paris: EHESS, GALLIMARD, SEUIL, 2013.

FOUCAULT, Michel. Os anormais. São Paulo: Martins Fontes, 2013b.

FOUCAULT, Michel. Vigiar e punir. 35ª ed. Rio de Janeiro: Vozes, 2008.

FRANÇA, Geminiano da. These II. Seção I. Annaes da Conferência Judiciária-Policial de 1917. Rio de Janeiro: Imprensa Nacional, 1918.

FRANCO, Maria Sylvia de Carvalho. Homens livres na ordem escravocrata. 4 ed. São Paulo: Editora UNESP, 1997.

FRANKLIN, Naila Ingrid Chaves. Raça, gênero e criminologia: Reflexões sobre o controle social das mulheres negras a partir da criminologia positivista de Nina Rodrigues. Dissertação de mestrado. Programa de Pós-Graduação em Direito. Universidade de Brasília, 2017.

FREIRE FILHO, Adelino de A. de Luna. A Nova Escola de Direito Criminal. Revista Acadêmica da Faculdade de Direito do Recife. Ano 1, volume 1, p. 27-35, 1891.

FREITAS, Felipe. Novas perguntas para a criminologia brasileira: poder, racismo e direito no centro da roda. Caderno CEAS, Salvador, n. 238, p. 488-499, 2016.

FREYRE, Gilberto. Sobrados e mucambos. São Paulo: Global, 2004.

GALEANO, Diego. Identidade cifrada no corpo: o bertillonnage e o Gabinete Antropométrico na Polícia do Rio de Janeiro, 1894-1903. Boletim do Museu Paraense Emílio Goeldi. Ciências Humanas, v. 7, n. 3, p. 721-742, set-dez, 2012.

GARZONI, Lerice de Castro. Nas fronteiras do não-trabalho: trabalhadoras pobres e as definições de vadiagem do início do século XX. Revista Mundo do Trabalho, v. 1, n, 2, 2009, p. 65-95.

GÓES, Luciano. A "tradução" de Lombroso na obra de Nina Rodrigues. Rio de Janeiro: Revan, 2016.

GOMES, Flávio dos Santos. Mocambos e quilombos. São Paulo: Claro Enigma, 2015.

GOMES, Nilma Lino. Alguns termos e conceitos presentes no debate sobre relações raciais no Brasil: uma breve discussão. HENRIQUES, Ricardo. (Org.). Educação anti-racista: caminhos abertos pela Lei Federal no. 10.639/03. Brasília: Ed.Brasília/ SECAD/MEC, p. 39$62,2005$.

GONZALEZ, Lélia. A categoria político-cultural da amefricanidade. Revista Tempo Brasileiro, Rio de Janeiro, n. 92/93, jan-jun, p. 69-82, 1988. 
GRINBERG, Keila. Liberata: a lei da ambiguidade - as ações de liberdade da corte de apelação do Rio de Janeiro do século XIX. [online]. Rio de Janeiro: Centro Edelstein de Pesquisa Social, 2010. Available from SciELO Books.

HOLLOWAY, Thomas H. O calabouço e o Aljube do Rio de Janeiro no século XIX. MAIA, C. N.; SÁ NETO, F. de; COSTA, M.; BRETAS, M. L. (orgs) História das prisões no Brasil. Volume I. Rio de Janeiro: Rocco, 2009.

HOLlOWAY, Thomas H. Polícia no Rio de Janeiro: repressão e resistência numa cidade do século XIX. Rio de Janeiro: Editora FGV, 1997.

HOOKS, bell. Feminism is for everybody: passionate politics. Cambridge: South End, 2000.

INSTITUTO DE DEFESA DO DIREITO DE DEFESA. Audiências de custódia: panorama nacional. 2017. Disponível em: < http://www.iddd.org.br/wp-content/uploads/2017/12/Audiencias-deCustodia_Panorama-Nacional_Relatorio.pdf $>$.

JESUS, Maria Gorete Marques de. O que está no mundo não está nos autos: a construção da verdade jurídica nos processos de crimes de tráfico de drogas. Tese de Doutorado. Programa de Pós-Graduação do Departamento de Sociologia da Universidade de São Paulo (FFLCHUSP). 2016.

KOERNER, Andrei. Habeas corpus, prática judicial e controle social no Brasil: 1841-1920. São Paulo: IBCCRIM, 1999.

KOERNER, Andrei. Punição, disciplina e pensamento penal no Brasil do século XIX. Lua Nova, São Paulo, 68, p. 205-242, 2006.

KOSELLECK, Reinhart. Futuro passado. Rio de Janeiro: Contraponto Editora, 2006.

LARRAURI, Elena. Mujeres y sistema penal: violencia doméstica. Montevideo, Buenos Aires: Editorial B de F, 2008.

LASCOUMES, Pierre. L'illégalisme, outil d’analyse. Société \& Représentations, nov, p. 7884, 1996.

LEAL, Aurelino. Germens do crime. Bahia: Livraria Magalhães, 1896.

LEAL, Aurelino. Polícia e poder de polícia. Rio de Janeiro: Imprensa Nacional, 1918.

LEAL, Aurelino. These I. Seção I. Annaes da Conferência Judiciária-Policial de 1917. Vol. 1. Rio de Janeiro: Imprensa Nacional, 1918.

LEAL, Aurelino. These I. Seção III. Annaes da Conferência Judiciária-Policial de 1917. Vol. 1. Rio de Janeiro: Imprensa Nacional, 1918.

LEAL, Aurelino. These III. Seção III. Annaes da Conferência Judiciária-Policial de 1917. Vol. 1. Rio de Janeiro: Imprensa Nacional, 1918.

LEÃO, Laurindo. A questão do crime, conceito e caracteres, de sua justificação, de suas variações e de sua naturalidade, evolução e factores. Revista Acadêmica da Faculdade de Direito do Recife. Ano 22, volume 22, p. 19-96, 1914. 
LIPNITZ, Guinter. Pesquisa historiográfica e documental: diálogos entre História e Direito a partir de escrituras públicas de contratos. MACHADO, Maíra Rocha. (org.) Pesquisar empiricamente o direito. São Paulo: Rede de Estudos Empíricos em Direito, p 225-248, 2017.

MAIA, Clarissa Nunes. A Casa de Detenção do Recife: controle e conflitos (1855-1915). MAIA, C. N.; SÁ NETO, F. de; COSTA, M.; BRETAS, M. L. (orgs) História das prisões no Brasil. Volume I. Rio de Janeiro: Rocco, 2009.

MAIA, Clarissa Nunes. Policiados: controle e disciplina das classes populares na cidade do Recife, 1865 - 1915. 252 f. Tese (Doutorado em História) - Universidade Federal de Pernambuco, Recife, 2001.

MAIA, Clarissa Nunes. Sambas, batuques, vozerias e farsas públicas: o controle social sobre os escravos em Pernambuco no século XIX (1850-1888). São Paulo: Annablume, 2007.

MATOS, Ilmar Rohloff de; CARVALHO, Maria Alice R. de. A polícia e a força policial no Rio de Janeiro. Estudo das características histórico-sociais das instituições policiais brasileiras, militares e paramilitares, de suas origens até 1930. Rio de Janeiro: PUC, 1981.

MBEMBE, Aquille. Necropolítica. Seguido de Sobre el Govierno privado indirecto. Espanha: Editorial Melusina, 2011.

McCLINTOCK, Anne. Couro Imperial. Raça, gênero e sexualidade no embate colonial. Campinas: Editora Unicamp, 2010.

MELOSSI, Dario; PAVARINI, Maximo. Cárcere e fábrica: as origens do sistema penitenciário (Século XVI-XIX) . 2 ed. Rio de Janeiro: Revan, 2010.

MENEZES, Mozart Vergetti. A Escola Correcional do Recife (1909-1929). MAIA, C. N.; SÁ NETO, F. de; COSTA, M.; BRETAS, M. L. (orgs) História das prisões no Brasil. Volume II. Rio de Janeiro: Rocco, 2009.

MIRANDA, Pontes de. História e prática do habeas - corpus. Tomo 1. $7^{\mathrm{a}}$ ed. Rio de Janeiro, Editor Borsoi, 1972.

MISSE, Michel. Rio como um bazar: a conversão da ilegalidade em mercadoria política. Insight inteligência, v.3, n. 5, p. 12-16, 2002.

MISSE, Michel. Sobre a Construção Social do Crime no Brasil: Esboços de uma Interpretação. MISSE, Michel (org). Acusados e Acusadores: Estudos sobre ofensas, acusações e incriminações. 2008.

MISSE, Michel. Sujeição Criminal. In: LIMA, Renato Sérgio de; RATTON, José Luiz; AZEVEDO, Rodrigo Ghiringhelli de. Crime, polícia e Justiça no Brasil. São Paulo: Editora Contexto, 2014.

MONET, Jean-Claude. Polícias e sociedades na Europa. São Paulo: Edusp, 2001.

MORAIS, Grasiela Florêncio de; ROSAS, Suzana.. "Livrando-se o público dos mendigos": o controle sobre os mendigos e o processo de criação do asilo de mendicidade do Recife no século XIX (1840 a 1870). Anais do II seminário internacional da SEO. Niterói: Sociedade de Estudos do Oitocentos, v. 2. p. 1-8, 2017. 
MOURA, Clovis. Sociologia do negro no Brasil. São Paulo: Editora Ática, 1988.

MUNIZ, Jacqueline; PROENÇA JR., Domício. Mandato policial. AZEVEDO, Rodrigo G. de; LIMA, Renato; RATTON, José Luiz (orgs). Crime, polícia e justiça no Brasil. São Paulo: Editora Contexto, 2014.

NABUCO, Joaquim. [1883]. O abolicionismo. Petrópolis: Vozes, 2012.

NASCIMENTO, Josino do. Código do Processo Criminal de Primeira Instância do Império do Brasil. 6 ed. TOMO I. Rio de Janeiro: Eduardo \& Henrique Laemmert, 1870.

NAZARETH, Francisco J. Duarte. Elementos do processo criminal. Coimbra: Imprensa da Universidade, 1886.

NEDER, Gislene. Iluminismo Jurídico-Penal Luso-Brasileiro. Obediência e submissão. 2 ed. Rio de Janeiro: Revan, 2007.

NOVAES, José. Força Pública do Estado de Pernambuco - Relatório. Recife: Imprensa Oficial do Estado, 1919.

OLIVEIRA, Luciano. De Rubens Paiva a Amarildo. E "Nego Sete"? O regime militar e as violações de direitos humanos no Brasil. 2016. MIMEO.

OLIVEIRA, Luciano. Neutros \& Neutros. Humanidades, n. 19, Brasília, p. 122-127, 1988.

OLIVEIRA, Luciano. O aquário e o Samurai: uma leitura de Michel Foucault. Rio de Janeiro: Lumen Juris, 2017.

OLIVEIRA, Luciano. O que todo estudante de direito deve ler para conhecer o Brasil: contribuição de um professor de sociologia jurídica. Anuário dos Cursos de Pós-Graduação em Direito (UFPE), v. 18, p. 57-97, 2008.

OLIVEIRA, Luciano. Relendo 'Vigiar e Punir'. Dilemas: Revista de Estudos de Conflito e Controle Social . Vol. 4, n. 2, ABR/MAI/JUN, p. 309-338, 2011.

OLIVEIRA, Luciano. Sua Excelência o Comissário e outros ensaios de sociologia jurídica. Rio de Janeiro: Letra Legal, 2004.

OMNÈS, Roland. Filosofia da ciência contemporânea. São Paulo: Editora UNESP, 1996.

OWUSU-BEMPAH, Akwasi. Race and policing in historical context : deshumanization and the policing of Black people in the 21th century. Theoretical criminology, 2016.

OZANAM, Israel. Capoeira e capoeiras entre a guarda negra e a educação física no Recife. Dissertação de Mestrado. Programa de Pós-Graduação em História. UFPE. Recife, 2013.

OZONAM, Israel. "Eu vou-me embora porque Apolônio da Capunga já anda na Boa Vista querendo prender gente": capoeira e polícia no Recife no início da República. Anais do XXVI Simpósio Nacional de História - ANPUH. São Paulo, julho, 2011.

PAULA, Liana de. Da “questão do menor" à garantia de direitos. Civitas, Porto Alegre, v. 15, n. 1, p. 27-43, jan.-mar, 2015. 
PEREIRA, Celso Viera de Mello. Tese VII. Seção 3. Annaes da Conferência JudiciáriaPolicial. Rio de Janeiro: Imprensa Nacional, 1918.

PIRES, Thula Rafaela de Oliveira. Criminologia crítica e pacto narcísico: por uma crítica criminológica apreensível em pretuguês. Revista Brasileira de Ciências Criminais. Ano 25, v. 135, p. 541-562, set, 2017.

PISCITELLI, Adriana G. Gênero em perspectiva. Cadernos Pagu, v. 11, p. 141-157, 1998.

PITANGA, Antônio Ferreira de Souza. Tese IV. Seção III. Annaes da Conferência Judiciária-Policial de 1917. Vol. I. Rio de Janeiro: Imprensa Nacional, 1918.

PORTELLA, Bruna. Embranquecer a cidade negra: gestão do trabalho de rua em Salvador no início do século XX. Dissertação de mestrado. Programa de Pós-Graduação em Direito, $\mathrm{UnB}, 2017$.

POSSENTI, S. O dado dado e o dado dado: o dado em análise do discurso. POSSENTI, S. (org.). Os limites do discurso: ensaios sobre discurso e sujeito. Curitiba: Criar Edições, 2 ed, p. 27-36, 2004.

PRADO, Geraldo. Sistema acusatório: a conformidade constitucional das leis processuais penais. Rio de Janeiro: Lumen Juris, 2005.

PRANDO, Camila C. de M. A contribuição do discurso criminológico latino-americano para a compreensão do controle punitivo moderno controle penal na América latina. Belo Horizonte: Veredas do direito, v.3, n. 6, jul/dez, 2006.

PRANDO, Camila C. de M. O saber dos juristas e o controle penal: o debate doutrinário a Revista de Direito Penal (1933-1940) e a construção da legitimidade pela defesa social. Rio de Janeiro: Revan, 2013.

QUEIROZ, Marcos Vinícius Lustosa. Constitucionalismo brasileiro e o atlântico negro: A experiência constitucional de 1823 diante da Revolução Haitiana. Dissertação de mestrado. Programa de Pós-Graduação em Direito. Universidade de Brasília, 2017.

RAGO, Margareth. Os prazeres da noite: prostituição e códigos da sexualidade feminina em São Paulo (1890-1930). São Paulo: Paz e Terra, 2008.

REPÚBLICA FEDERATIVA DOS E. U. DO BRAZIL.POLÍCIA CIVIL DO DISTRITO FEDERAL. Boletim policial, Ano I, Volume 5, 1907.

REPÚBLICA FEDERATIVA DOS E. U. DO BRAZIL.POLÍCIA CIVIL DO DISTRITO FEDERAL. Boletim policial, Ano I, Volume 1, 1907.

REPÚBLICA FEDERATIVA DOS E. U. DO BRAZIL.POLÍCIA CIVIL DO DISTRITO FEDERAL. Boletim policial, Ano III, Volume 12, 1910.

REPÚBLICA FEDERATIVA DOS E. U. DO BRAZIL.POLÍCIA CIVIL DO DISTRITO FEDERAL. Boletim policial, Ano I, Volume 6, 1907.

REPÚBLICA FEDERATIVA DOS E. U. DO BRAZIL.POLÍCIA CIVIL DO DISTRITO FEDERAL. Boletim policial, Ano I, Volume 2, 1907. 
REPÚBLICA FEDERATIVA DOS E. U. DO BRAZIL.POLÍCIA CIVIL DO DISTRITO FEDERAL. Boletim policial, Ano II, Volume 1, 1908.

REPÚBLICA FEDERATIVA DOS E. U. DO BRAZIL.POLÍCIA CIVIL DO DISTRITO FEDERAL. Boletim policial, Ano I, Volume 3, 1907.

ROMANO, Roberto. Razão de Estado e outros estados de razão. São Paulo: Perspectiva, 2014.

RUSCHE, Georg; KIRCHHEIMER, Otto. [1939] Punição e estrutura social. 2 ed. Rio de Janeiro: Revan, 2004.

SANT'ANNA, Marilene Antunes. Trabalho e conflitos na casa de correção do Rio de Janeiro. MAIA, C. N.; SÁ NETO, F. de; COSTA, M.; BRETAS, M. L. (orgs) História das prisões no Brasil. Volume I. Rio de Janeiro: Rocco, 2009.

SANTOS, Gislene Aparecida dos. A invenção do "ser negro": um percurso das ideias que naturalizaram a inferioridade dos negros. São Paulo/Rio de Janeiro: 2002.

SANTOS, Hugo Leonardo. Por uma história crítica dos conceitos jurídico-penais: fundamentos teórico-metodológicos a partir de uma aproximação entre Michel Foucault e Reinhart Koselleck. Tese de Doutorado. Programa de Pós-Graduação em Direito da Universidade Federal de Pernambuco. 2015.

SANTOS, Misael. Os usos da força física por Policiais Militares: descrevendo práticas, entendendo sentidos. Dissertação de Mestrado. Programa de Pós-Graduação em Ciências Sociais, UFBA, 2014.

SCHWARCZ, Lilia M. O espetáculo das raças: cientistas, instituições e questão racial no Brasil. São Paulo: Companhia das Letras, 1993.

SCHWARCZ, Lilia M.; STARLING, Heloísa M. Brasil: uma biografia. São Paulo: Companhia das Letras, 2015.

SCHWARZ, Roberto. As ideias fora do lugar: ensaios selecionados. São Paulo: Penguin Classics Companhia das Letras, 2014.

SILVA, Eduardo. As queixas do povo. Rio de Janeiro: Paz e Terra, 1988.

SILVA, Fernanda Lima da. Policiados e policiais. Dois tempos de uma história de criminalização. Monografia de final de curso. Faculdade de Direito do Recife-UFPE, 2016.

SILVA, Wellington Barbosa da. Entre a liturgia e o salário: a formação dos aparatos policiais no Recife do Século XIX (1830-1850). Tese de Doutorado. Recife: Universidade Federal de Pernambuco, PPGH, 2003.

SIQUEIRA, Galdino. These IX. Annaes da Conferência Judiciária-Policial de 1917. Rio de Janeiro: Imprensa Nacional, 1918.

SOARES, Oscar Macedo. [1910] Código Penal da Republica dos Estados Unidos do Brasil commentado. Brasília: Senado Federal, Superior Tribunal de Justiça, Coleção História do Direito, vol. 6, 2004. 
SOUZA, Braz Florentino Henriques de. Código do Processo Criminal de Primeira Instância do Império do Brasil. Recife: Tipografia Universal, 1860.

SOUZA, Luiz Antônio Francisco de. Lei, cotidiano e cidade: polícia civil e práticas policiais na São Paulo republicana (1889-1930). São Paulo: IBCCRIM, 2009.

SOUZA, Luiz Antônio Francisco de. Polícia, poder de polícia e criminalidade numa perspectiva histórica. KOERNER, Andrei (org.). História da justiça penal no Brasil: pesquisas e análises. São Paulo: IBCCRIM, p. 59-82, 2006.

SOZZO, Maximo. Polícia, governo e racionalidade: incursos a partir de Michel Foucault. Discursos Sediciosos. Rio de Janeiro: Revan, ano 17, número 19/20, p. 511-554, 2012.

SOZZO, Maximo. Viagens culturais e a questão criminal. Rio de Janeiro: Revan, 2014.

STACK, Carol. Roles sexuales y estratégias de supervivencia en una comunidad negra urbana. JABARDO, Mercedes (org). Feminismos negros: una antologia. Madrid: Traficantes de Sueños, 2012.

SWENSSON JR. Walter Cruz. O Supremo Tribunal Federal (1964-1969). KOERNER, Andrei (org.). História da justiça penal no Brasil: pesquisas e análises. São Paulo: IBCCRIM, p. 227-240, 2006.

TAVARES, Octavio. O problema penitenciário entre nós. Revista Acadêmica da Faculdade de Direito do Recife. Ano 28, volume 28, p. 31-45, 1920.

TÓRTIMA, Pedro. Crime e castigo para além do Equador. Belo Horizonte: Inédita, 2002.

TORTIMA, Pedro. Polícia e justiça de mãos dadas: A conferência Judiciário-Policial de 1917. Dissertação de Mestrado. Instituto de Ciências Humanas e Filosofia. Centro de Estudos Gerais. Universidade Federal Fluminense, 1988.

VALENTE, Manuel Monteiro Guedes. A polícia do Estado Democrático de Direito. Florianópolis: Empório do Direito, 2015.

VALLE, Diógenes Pereira do. Dos processos policiais. São Paulo: EGR, 1928.

WANDERLEY, Gisela Aguiar. Liberdade e suspeição no Estado de Direito: o poder policial de abordar e revistar e o controle judicial de validade da busca pessoal. Dissertação de Mestrado. Programa de Pós-Graduação em Direito. UnB. 2017.

WEBER, Max. Ensaios de sociologia. Rio de Janeiro: Zahar Editores,1963.

WEINBERGER, Barbara; REINKE, Herbert. A disminishing function? A comparative historical account of policing in the city. Policing and society, vol 1, 1991, p. 213-223.

ZACCONE, Orlando. Indignos de vida: a forma jurídica da política de extermínio de inimigos na cidade do Rio de Janeiro, 2015.

ZAFFARONI, E. R.; BATISTA, N; ALAGIA, A.; SLOKAR, A. Direito penal brasileiro - I. Rio de Janeiro: Revan, 2006. 
ZAFFARONI, Eugenio Raul. Las "clases peligrosas": el fracasso de un discurso policial prepositivista. Sequência, Ano XXV, dezembro, p. 141-168, 2005.

ZAFFARONI, Eugênio Raul. Criminologia: Aproximación desde un margen. Bogotá: Editorial Themis, 1988.

ZAFFARONI, Eugenio Raúl. Em busca das penas perdidas: a perda da legitimidade do sistema penal. Rio de Janeiro: Revan, 1991.

- Fontes pesquisadas no APEJE:

FUNDO SECRETARIA DE SEGURANÇA PÚBLICA (SSP):

APEJE, Fundo SSP, livro 455, Livro de Ofícios de Delegados e Subdelegados da $1^{\text {a }}$ Delegacia de Polícia, 1915.

APEJE, Fundo SSP, livro 456, Livro de Ofícios de Delegados e Subdelegados da $1^{\text {a }}$ Delegacia de Polícia, 1916.

APEJE, Fundo SSP, livro 457, Livro de Ofícios de Delegados e Subdelegados da $1^{\text {a }}$ Delegacia de Polícia, 1916.

APEJE, Fundo SSP, livro 458. Livro de Ofícios de Delegados e Subdelegados da $1^{\text {a }}$ Delegacia de Polícia. 1917.

APEJE, Fundo SSP, livro 459. Livro de Ofícios de Delegados e Subdelegados da $1^{\text {a }}$ Delegacia de Polícia. 1918.

APEJE, Fundo SSP, livro 460. Livro de Ofícios de Delegados e Subdelegados da $1^{\text {a }}$ Delegacia de Polícia. 1919.

APEJE, Fundo SSP, livro 461. Livro de Ofícios de Delegados e Subdelegados da $1^{\text {a }}$ Delegacia de Polícia. 1920.

APEJE, Fundo SSP, livro 462. Livro de Ofícios de Delegados e Subdelegados da $1^{\text {a }}$ Delegacia de Polícia. 1921.

APEJE, Fundo SSP, livro 463. Livro de Ofícios de Delegados e Subdelegados da $1^{\text {a }}$ Delegacia de Polícia. 1921.

APEJE, Fundo SSP, livro 468. Livro de Ofícios de Delegados e Subdelegados da $1^{\text {a }}$ Delegacia de Polícia. 1922.

APEJE, Fundo SSP, livro 464. Livro de Ofícios de Delegados e Subdelegados da $1^{\text {a }}$ Delegacia de Polícia. 1923.

APEJE, Fundo SSP, livro 465. Livro de Ofícios de Delegados e Subdelegados da $1^{\text {a }}$ Delegacia de Polícia. 1924.

APEJE, Fundo SSP, livro 466. Livro de Ofícios de Delegados e Subdelegados da $1^{\text {a }}$ Delegacia da Capital, 1925.

APEJE, Fundo SSP, livro 467. Livro de Ofícios de Delegados e Subdelegados da $1^{\text {a }}$ Delegacia da Capital, 1926. 
APEJE, Fundo SSP, livro 469. Livro de Ofícios de Delegados e Subdelegados da $1^{\text {a }}$ Delegacia de Polícia. 1927.

APEJE, Fundo SSP, livro 470. Livro de Ofícios de Delegados e Subdelegados da $1^{\text {a }}$ Delegacia de Polícia. 1928.

APEJE, Fundo SSP, livro 471. Livro de Ofícios de Delegados e Subdelegados da $1^{\text {a }}$ Delegacia de Polícia. 1929.

APEJE. Fundo SSP, livro 1315. Ofícios da Chefia de Polícia de Pernambuco. 1914/1916.

APEJE. Fundo SSP, livro 1316. Ofícios da Chefia de Polícia de Pernambuco. 1917/1918.

APEJE. Fundo SSP, livro 1317. Ofícios da Chefia de Polícia de Pernambuco. 1919.

APEJE, Fundo SSP, Caixa 2. Relatório da Chefia de Polícia, 1918.

APEJE, Caixa 2. Regulamento do Corpo Policial, expedido em 25 de agosto de 1896, pelo governador Joaquim Corrêa de Araújo, 1896.

APEJE, Fundo SSP, Casa de Detenção do Recife. Livro de entradas e saídas. 1920.

FUNDO SECRETARIA GERAL (SG):

APEJE, Fundo SG, volume 200. R elatório da Chefia de Polícia, 1912.

FUNDO SECRETARIA DE JUSTIÇA (SJ):

APEJE, Fundo Secretaria de Justiça, Livro 190, Relatório da Chefia de Polícia, 1914.

APEJE, Fundo Secretaria de Justiça, Livro 200, Relatório da Chefia de Polícia, 1923.

APEJE, Fundo Secretaria de Justiça, Livro 202, Relatório da Chefia de Polícia, 1928. 
ANEXOS 
ANEXO 1 - Organograma das forças de segurança pública do Estado de Pernambuco (1891 a 1930)

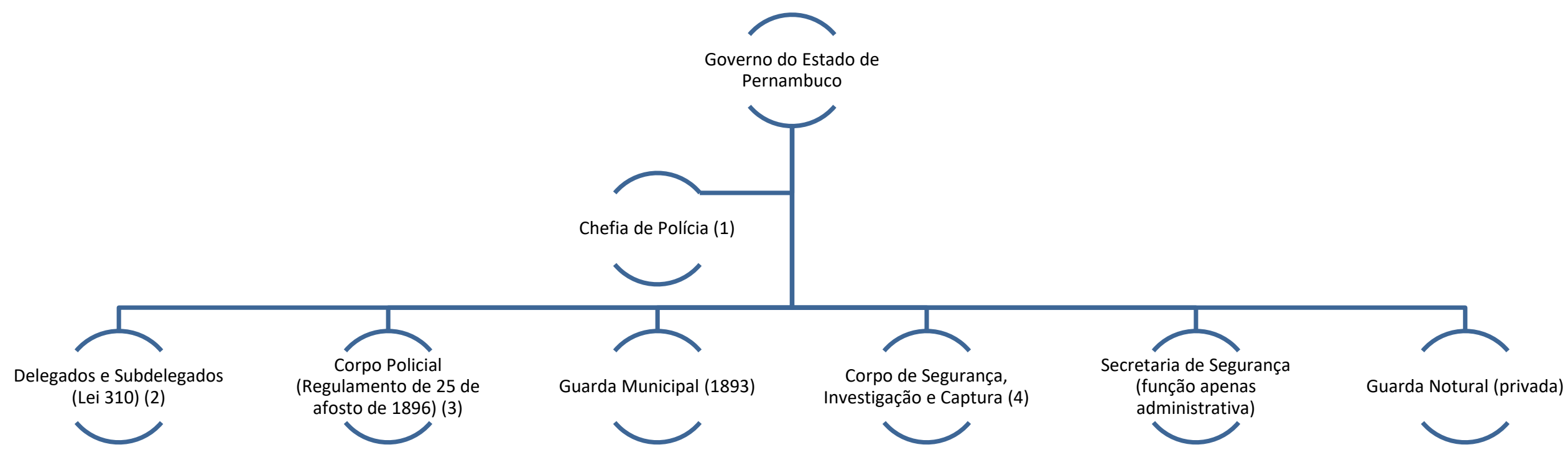

(1) CARGO DE LIVRE NOMEAÇÃO E EXONERAÇÃO POR PARTE DO GOVERNADOR DO ESTADO, DEVENDO O SEU TITULAR SER FORMADO EM DIREITO.

(2) POLÍCIA CIVIL - POLÍCIA JUDICIÁRIA, TENDO COMO PRINCIPAL FUNÇÃO A INVESTIGAÇÃO DE CRIMES.

(3) POLÍCIA OSTENSIVA E PREVENTIVA. DE NATUREZA MILITAR E COM COMANDOS ESCOLHIDOS PELO GOVERNADOR DO ESTADO.

(4) CRIADO NO GOVERNO DE MANOEL BORBA, EM 1918, COM A FINALIDADE DE REALIZAR INVESTIGAÇÃO, PREVENÇÃO E VIGILÂNCIA POLICIAL, COMPOSTO DE UM INSPETOR, UM ESCRITURÁRIO E VINTE E CINCO AGENTES. 
ANEXO 2 - Carta do preso correcional Benedicto Ribeiro de 1925 encaminhada ao Chefe de Polícia em que pede clemência para ser solto ${ }^{441}$.

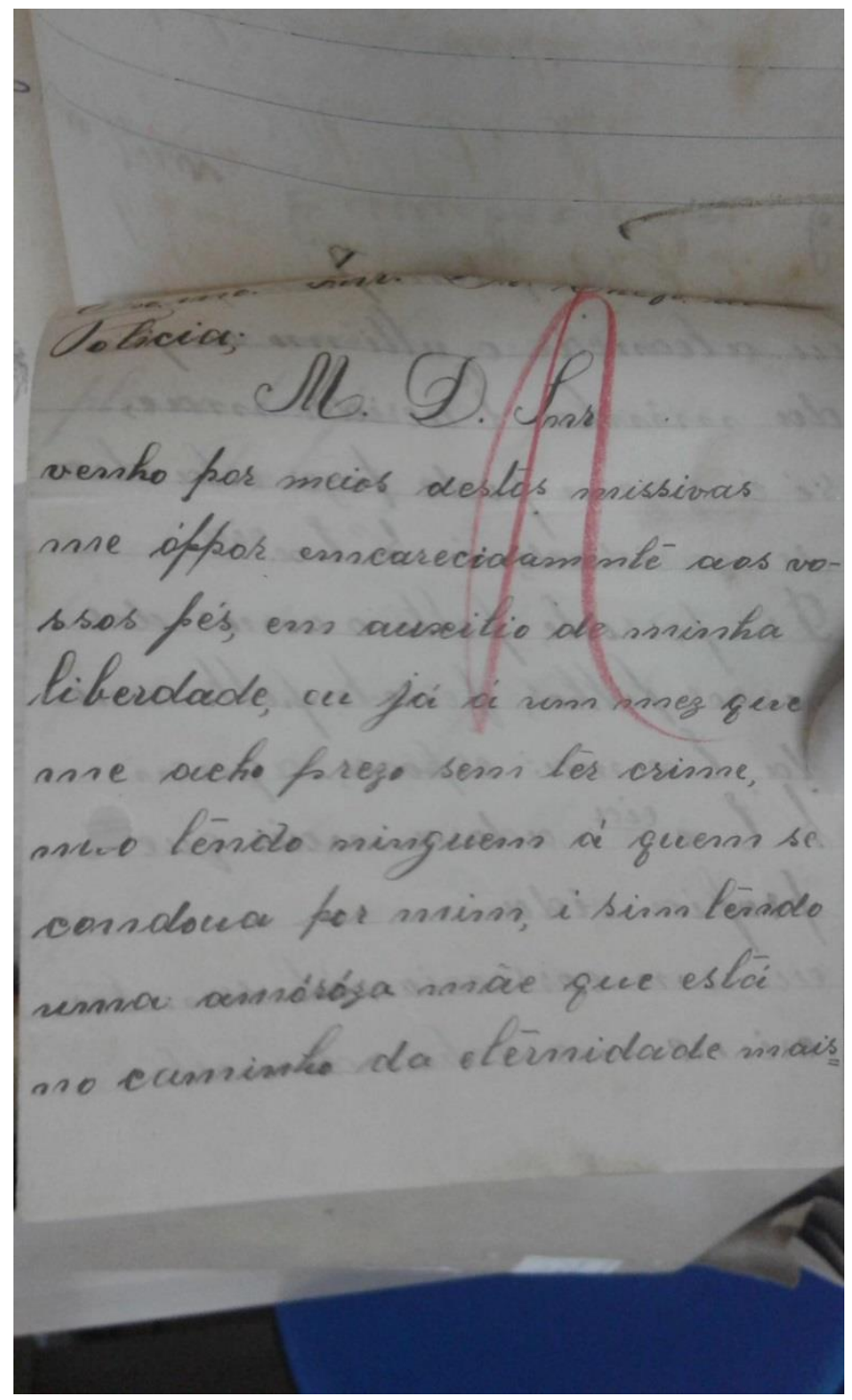

${ }^{441}$ Fonte: APEJE, Fundo SSP, livro 466. Relatórios de delegados e subdelegados de polícia, $1^{\text {a }}$ Delegacia da Capital, 1925. 


\section{7}

$x^{2}=$

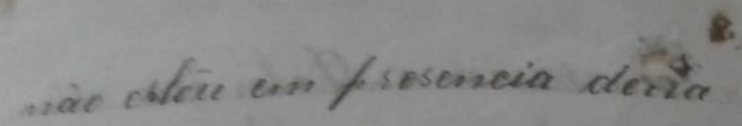
favar pue des man jeilo sebie rsbe nlli-nano susfiro.

porens só é quen foode fages eu alcaneair oulli-no seerfiro da minstar Euesidar mave, se é guen fode fager està obea de caridade $e^{\prime}$ S. C Lo ina. Qs. pesse-te pelto o ansor dos vesses fithos pesso-le fielto ansios da Coe mai esfösos ageecon 1. Ox eice adora sonas que i propia vida.

ue unn cosseccionsoif sens lé exine ane cuehounds noste =
का carête sendo cu nem homiade dens da wrish a famitiog e seren froder das jeito à nem alo de condicies messossarice sobre ai misika susuther en flemo térpo de gravides. ora Gotos que amargura sinto cer en num carede penseando di neilé dé olia sem poder dar um jeite solie ci minka famitice.

porens esfero ser attendido

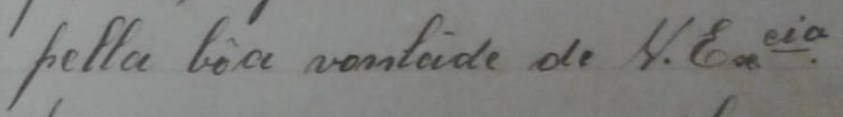
para conn suns dórréceional. Béméclietó Dibeiro 
ANEXO 3 - Carta do preso correcional José Herminio dos Santos, vulgo "Bicudo", encaminhada ao Chefe de Polícia em que pede clemência para ser solto ${ }^{442}$

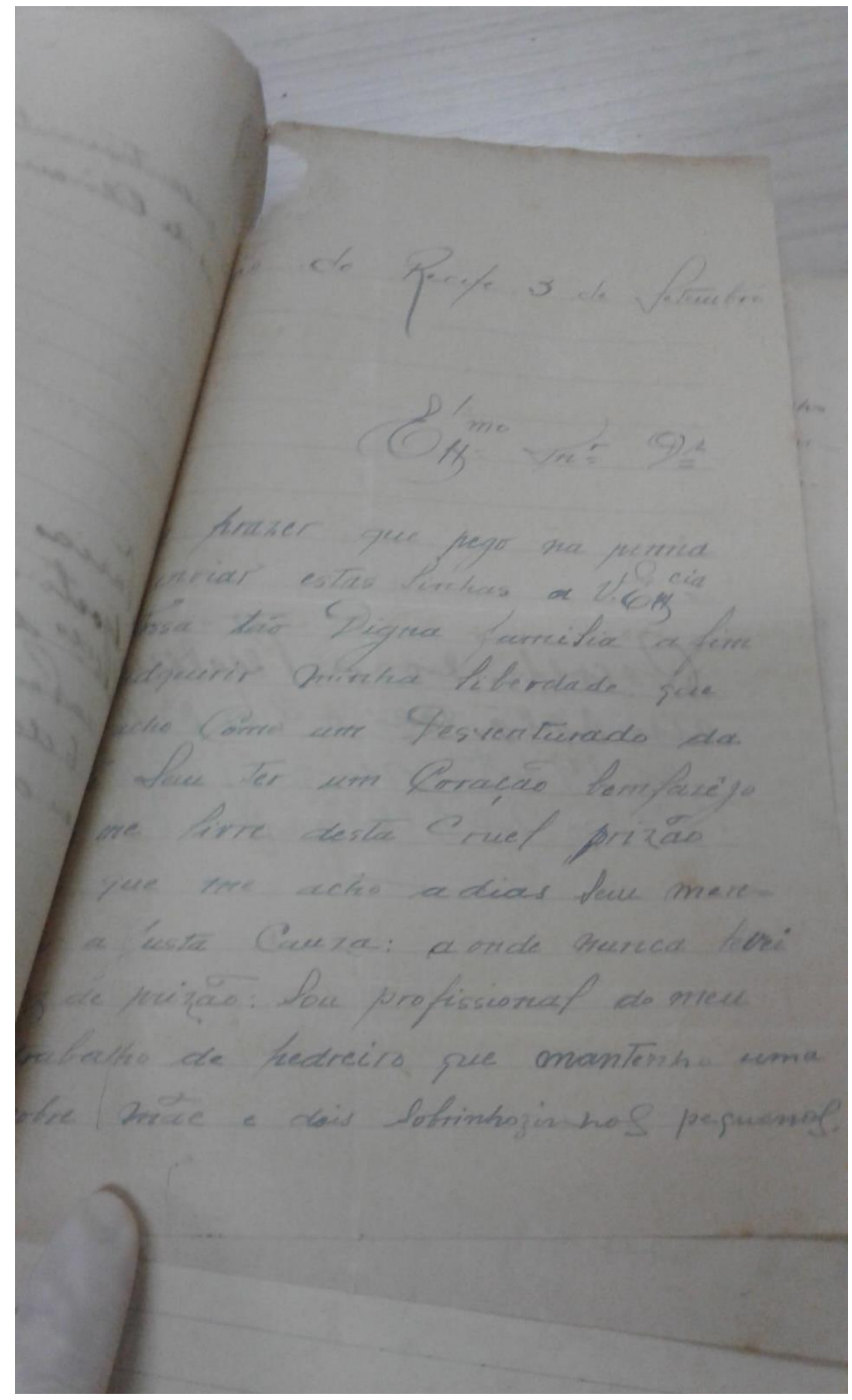

${ }^{442}$ APEJE, Fundo SSP, livro 466. Relatórios de delegados e subdelegados de polícia, $1^{\text {a }}$ Delegacia da Capital, 1925. 


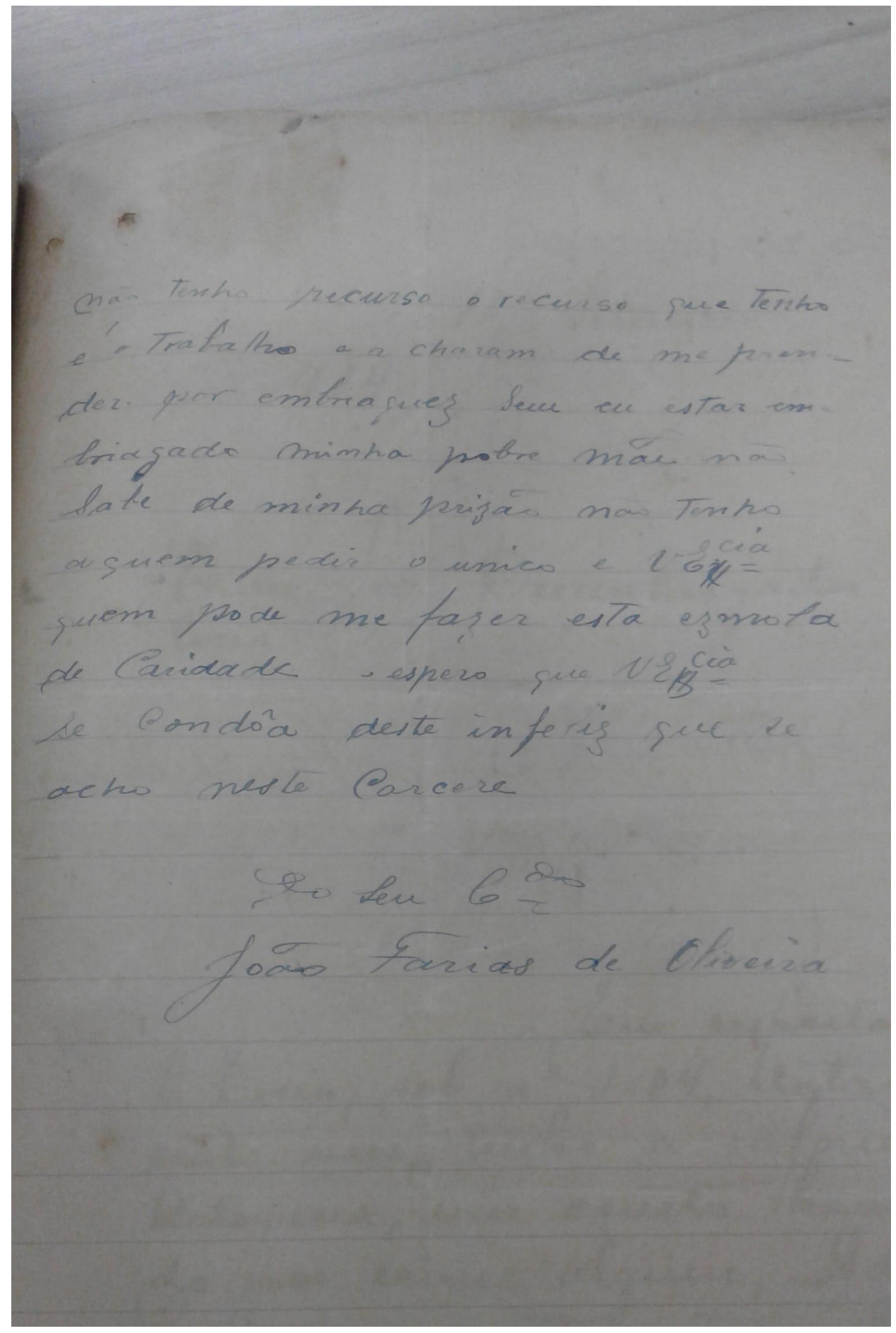


ANEXO 4 - Charge de J. Carlos (anexo 4), de $1908^{443}$

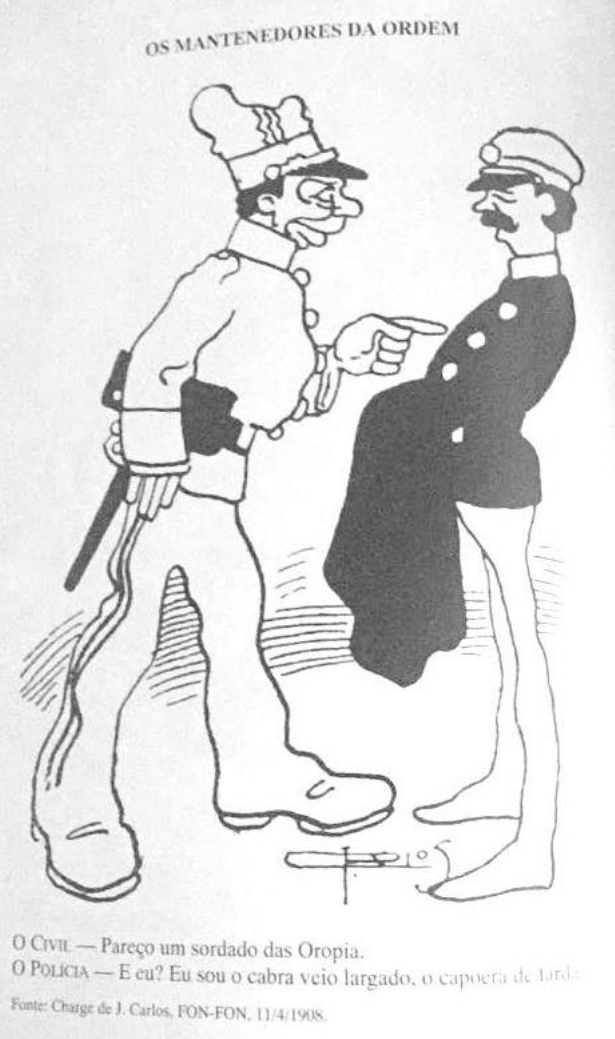

${ }^{443}$ Lê-se na charge: "Os mantenedores da ordem. -O civil: Pareço um soldado das Oropia. - O Policia: e eu? Eu sou o cabra veio largado, o capoeira de farda". 
ANEXO 5 - Fotografia da Guarda Civil do Distrito Federal. Ano $1907^{444}$

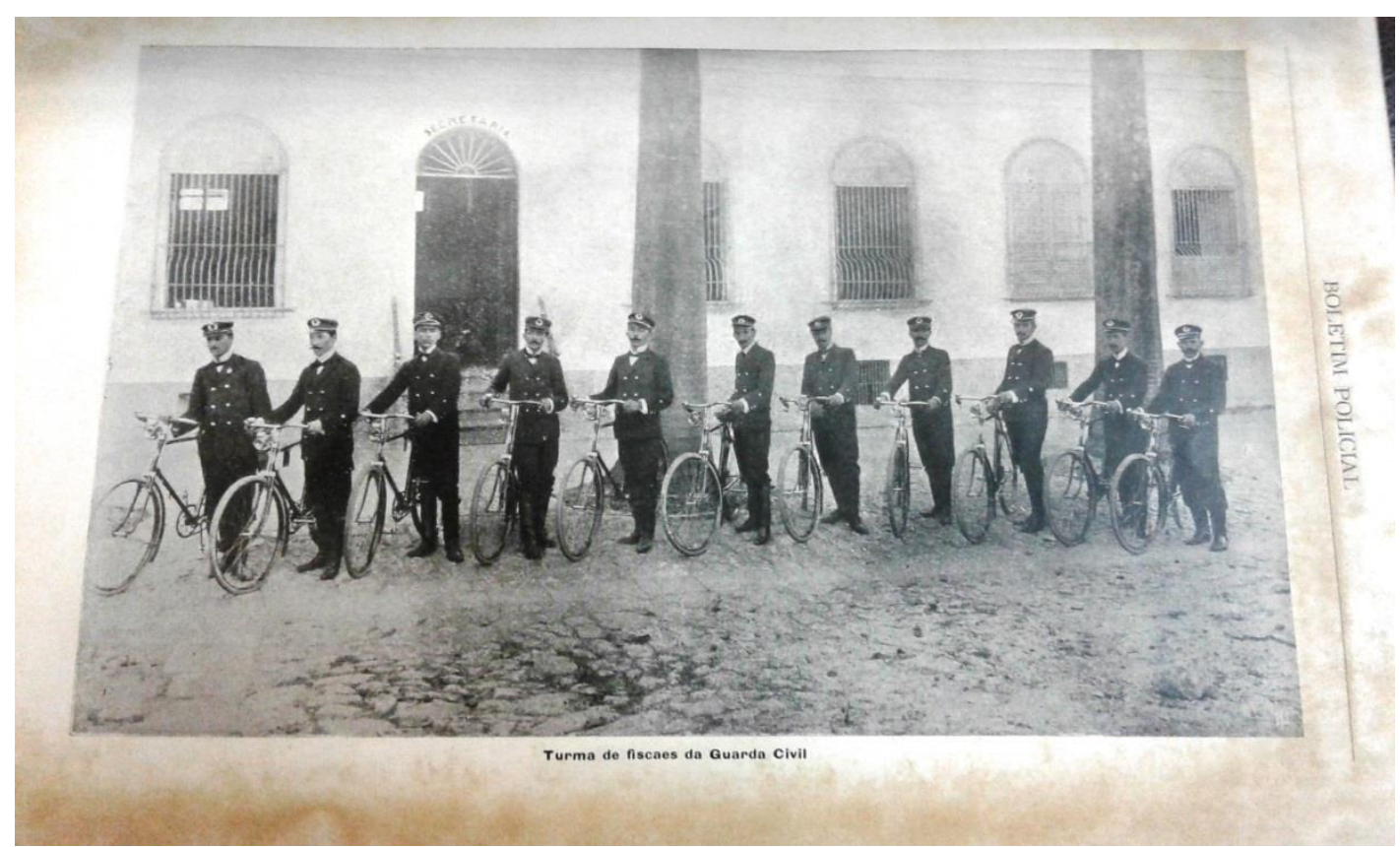

${ }^{444}$ Fonte: Boletim Policial. 
ANEXO 6 - Organização da justiça - Código de Processo Criminal de 1832

1. Distritos

- 1 juiz de paz: eleito pelo povo

- Escrivão: nomeado pela Câmara Municipal

- Inspectores de quarteirão: nomeados pela Câmara Municipal

2. Termos

- Conselho de Jurados ( $1^{\circ}$ Conselho e Júri de Sentença): cidadãos inscritos

- Juízes Municipais: nomeados, no Governo, pela Corte e nas províncias pelos presidentes, após proposta de lista tríplice da Câmara Municipal.

- Promotores Públicos: nomeados, no Governo, pela Corte e nas províncias pelos presidentes, após proposta de lista tríplice da Câmara Municipal.

- Escrivão

\section{Comarcas}

- Juiz de Direito (nas com três ou mais juízes, um seria obrigatoriamente Chefe de Polícia) 
ANEXO 7 - Relação das teses aprovadas na Conferência Judiciária-Policial de 1917 e seu respectivo autor.

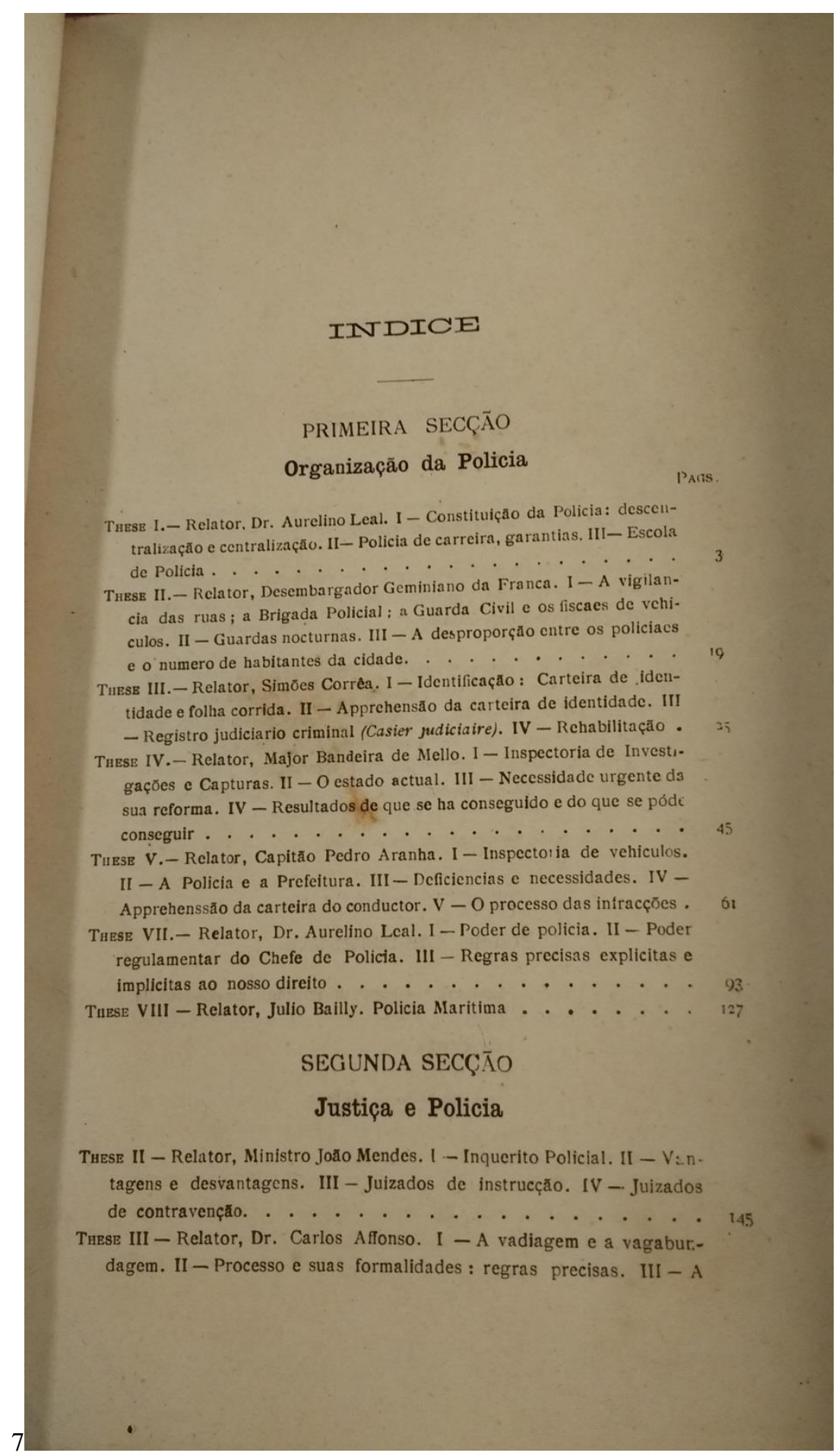



fiança idonea do art. 4 गr do Codıgo Penal: exigencias que é licito ao
Juiz fazer pata provar a idoneidade do fiador. $\mathrm{IV}-$ Necessidade verificar essa idoneidade. . . . . . . .

TheSE IV - Relator, Dr. Alfredo Russell. I - Penas pecuniarias. II - $-\dot{C}^{\cdot} \cdot$

travençōes a que devem ser applicadas. . . . .

These V - Relator, Dr. Armando Vidal. I - A questão $\cdot{ }^{*} \cdot$. . . nossas leis a respeitı. III - Jogos permittidos : enumeracão. II - As dencial. IV - Jogo do bicho. V - Como se deve : enumeração jurispru. da nossa legislação. VI - Deficiencia se deve reprimir no estado actual

THese VI - Relator, Ministro Viveiros de Castro. I - Liberdades istas duaes. II - Restricçōes que decorrem dos principioserdades indivie da lei escripta. III - Conflicto entre liberdades. IV - A aces do direito

These VIT. Relator, Dr. Rodrigo Octavio. I-Policia dos estrangeiros. II - A reside.ıcia no Brasil. III - Necessidade de alterar seu conceito em relação áquelles, no direito civil, em bem da ordem publica. IV O que se póde fazer em materia de expulsão em face da nossa legislação. . . . . . . . . . . . . . . . . . . .

THESE IX.-Relator, Dr. Galdino de Siqueira. I - Vigilancia das sociedades operarias. II - Gréves. III - Identificação dos trabalhadores do Estado ou de repartiçōes delle dependentes. IV - A policia e os menores empregados e operarios . . . . . . . . . . . . . . . .

These XI. - Relator, Dr. Astolpho Rezende. I - Manutenção de posse e interdicto prohibitorio contra actos da Policia. II - A acção summiria especial e a justiça local. III - Effeitos dos embargos oppostos aos interdictos. IV - Pode o juiz ouvir preliminarmente a autoridade? .

THEse XII.- Relator, Desembargador Caetano Montenegro. I - O salvo conducto nos casos de habeas-corpus. II - Perigo da liberalidade em concedel-o. III - Concedido habeas-corpus em consequencia de acto do chefe de Policia, pode este recorrer da decisão?

\section{TERCEIRA SECÇĀO}

\section{Policia Administrativa}

THESE I. - Relator, Dr. Aurelino Leal. I - Papel da imprensa no dominio da policia. II - Difficuldades que a imprensa crêa á repressão. III - Necessidade de um appello aos jornalistas . . . . . . . . .

These II.- Relator, Dr. Alvaro Berford. I - A pornographia. II - O que estampas, fazer dentro das leis actuaes.

Taese III.-Relator, Dr. Aurelino Leal I • • • • • • • . • . . 360

THese IV - Relator, Desembargacal. I- A prostituiç็̃o. II-Localização. 403 digos. II - Poder admitanga. I-Loucos e men15 
PaGs.

These V - Relator, Dr. Cid Braune. I-Hospedarias, casas de commodos, de tolerancia, etc. II - A Prefeitura e a Policia. . . . . . . . These VI.-Relator, Dr. Henrique de Laet. I - Diversões publicas. II Theatros e cinematographos. III - A censura. IV - Cafés-concertos,

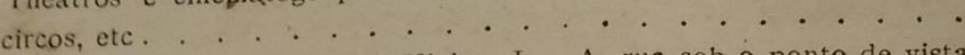

These VII - Relator, Dr. Celso Vieira. I - A rua sob o ponto de vista moral. II - O que a policia póde fazer. III - O circulez. . . . . .

These VIII - Relator, Dr. Edgard Costa. I - O problema da infancia abandonada em geral. II - O que se deve fazer. . . . . . . . 503

These IX. - Relator, Dr. Souza Gomes. I.- Repressão ao alcoolismo. II - O art. ro da lei n. r. 36 r, de 3 de janeiro de 1907 , e o art. 247 do regulamento $\mathrm{n} .6 .440$, de 30 de março de 1907 . III - Plano pratico de

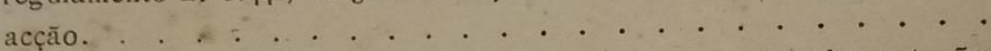

These X. - Relator, Desembargador Saraiva Junior. I - Regulamentação da venda e uso de armas prohibidas, materias explosivas e toxicos em geral II. - O Regulamento n. 6.440, de 30 de março de IgOZ • •

These XI.- Relator, Dr. Jorge Gomes de Mattos. 1- Casas de penhores. II - Suz fiszalização. III - Reformas . . . . . . . . . . . •

Rio de Janeiro - Imprensa Nacional - 1918 
ANEXO 8 - Gráfico do Relatório da Chefia de Polícia que demonstra a queda vertiginosa no número de homicídios no Recife entre 1921 e 1927

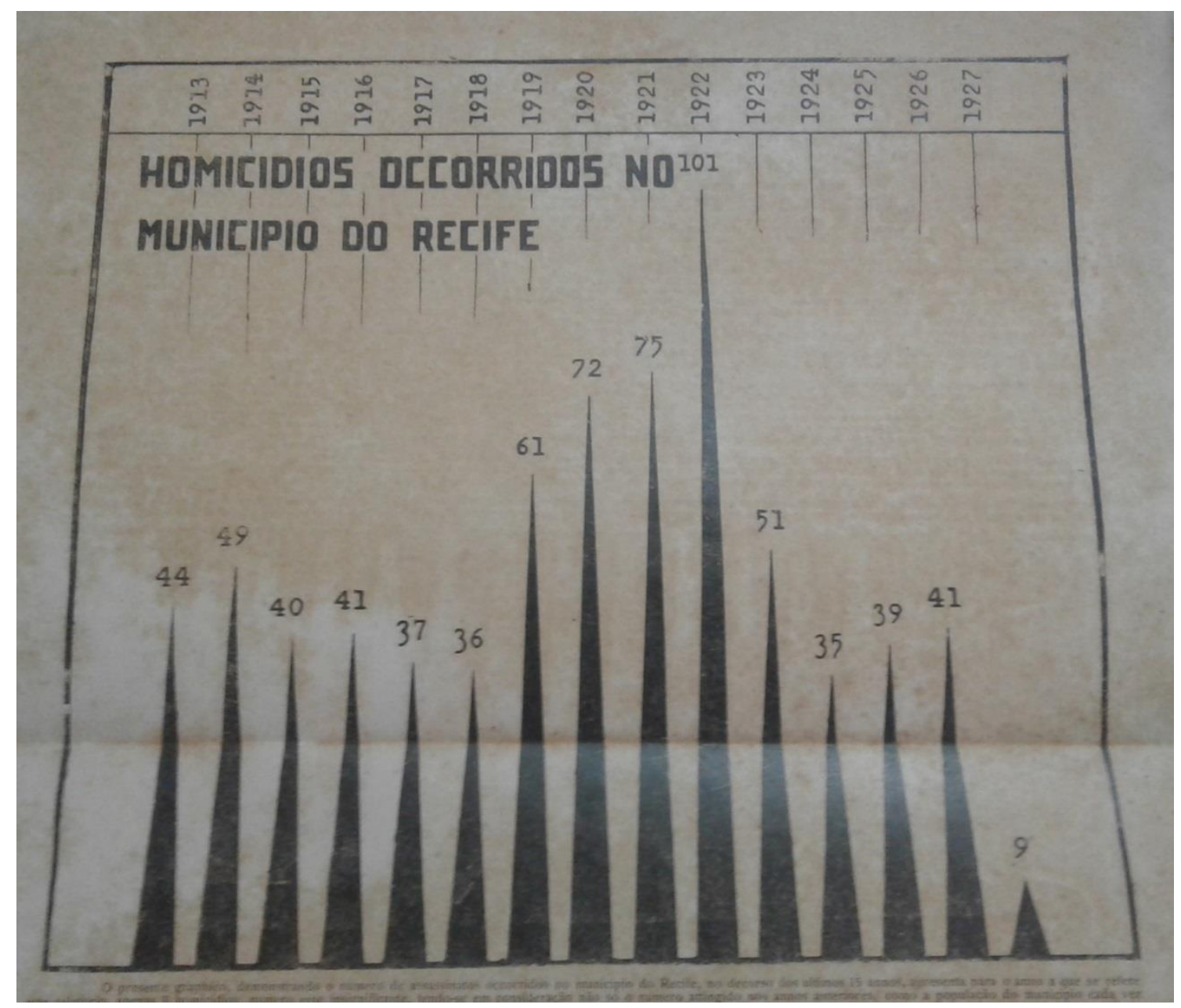


ANEXO 9 - Escola Correcional do Recife - $1927^{445}$

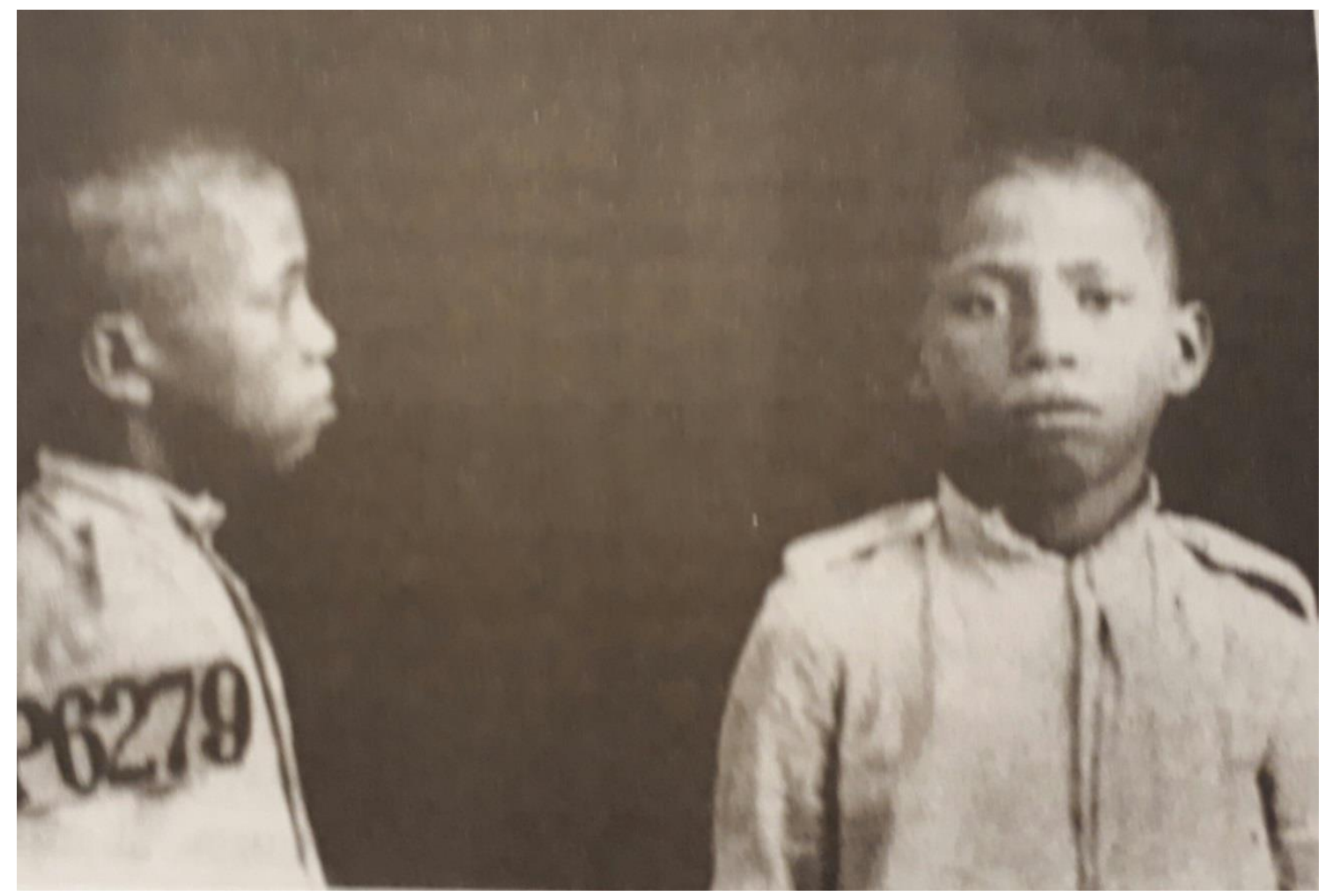

ANEXO 10 - Charge...

${ }^{445}$ Fonte: MENEZES, Mozart Vergetti. A Escola Correcional do Recife (1909-1929). MAIA, C. N.; SÁ NETO, F. de; COSTA, M.; BRETAS, M. L. (orgs) História das prisóes no Brasil. Volume II. Rio de Janeiro: Rocco, 2009, p. 252. 


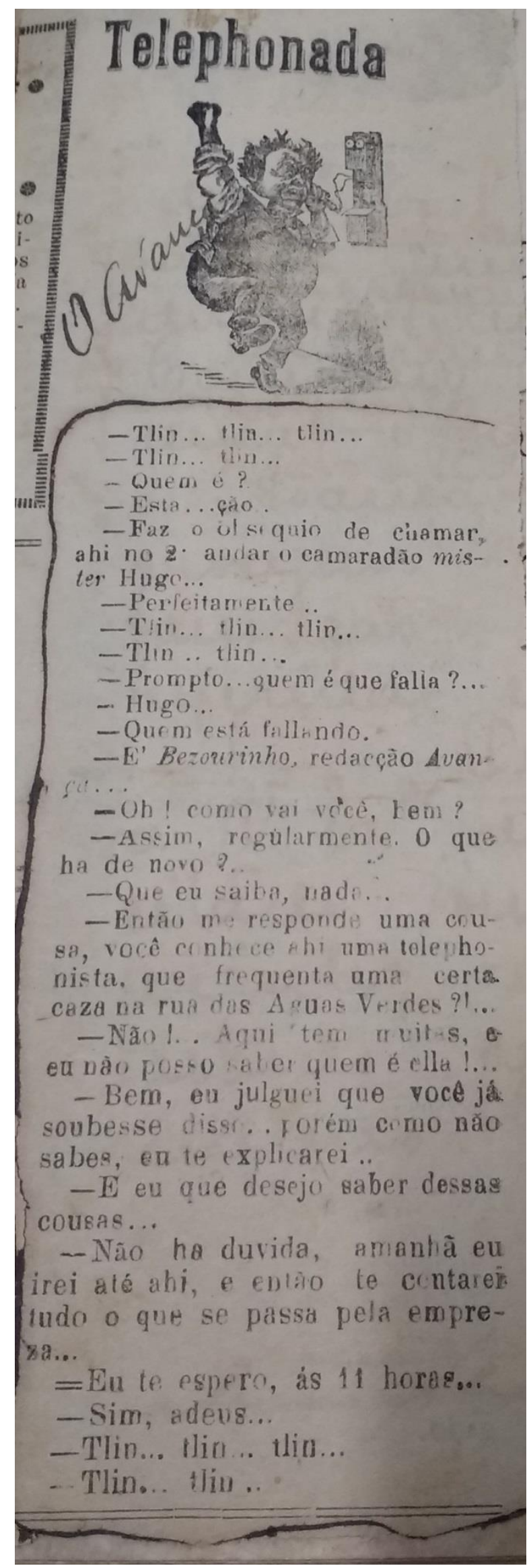


ANEXO 11 - Lista do livro de ofícios de delegados e subdelegados da $1^{\text {a }}$ Delegacia da Capital de 1926 das casas de prostituição, localização e nome da mulher responsável pelo local

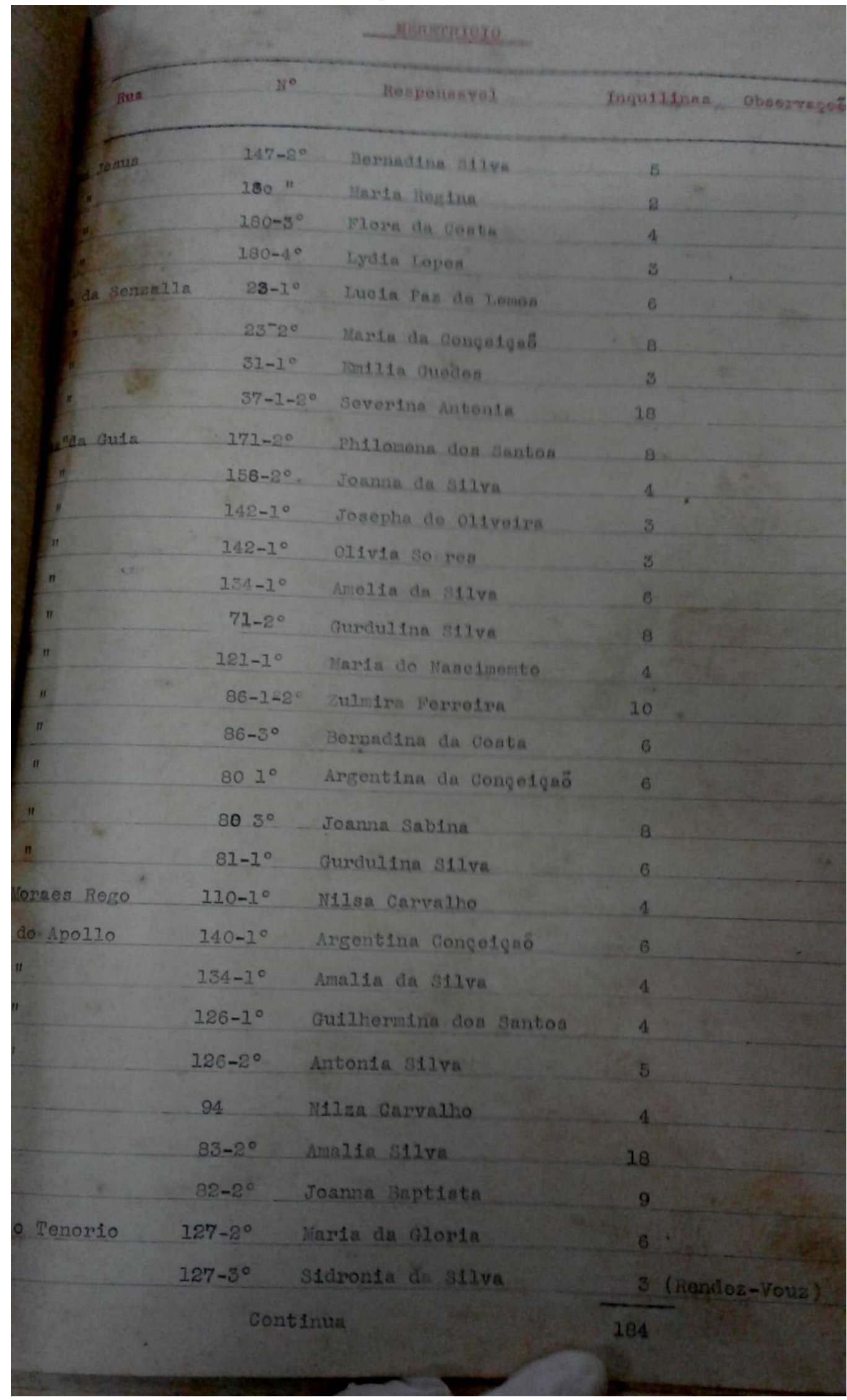


ANEXO 12 - Ofício trocado entre chefes de polícia com indicação dos nomes, fotografias e identificação datiloscópica dos indivíduos considerados de máxima periculosidade por suas ideias subversivas

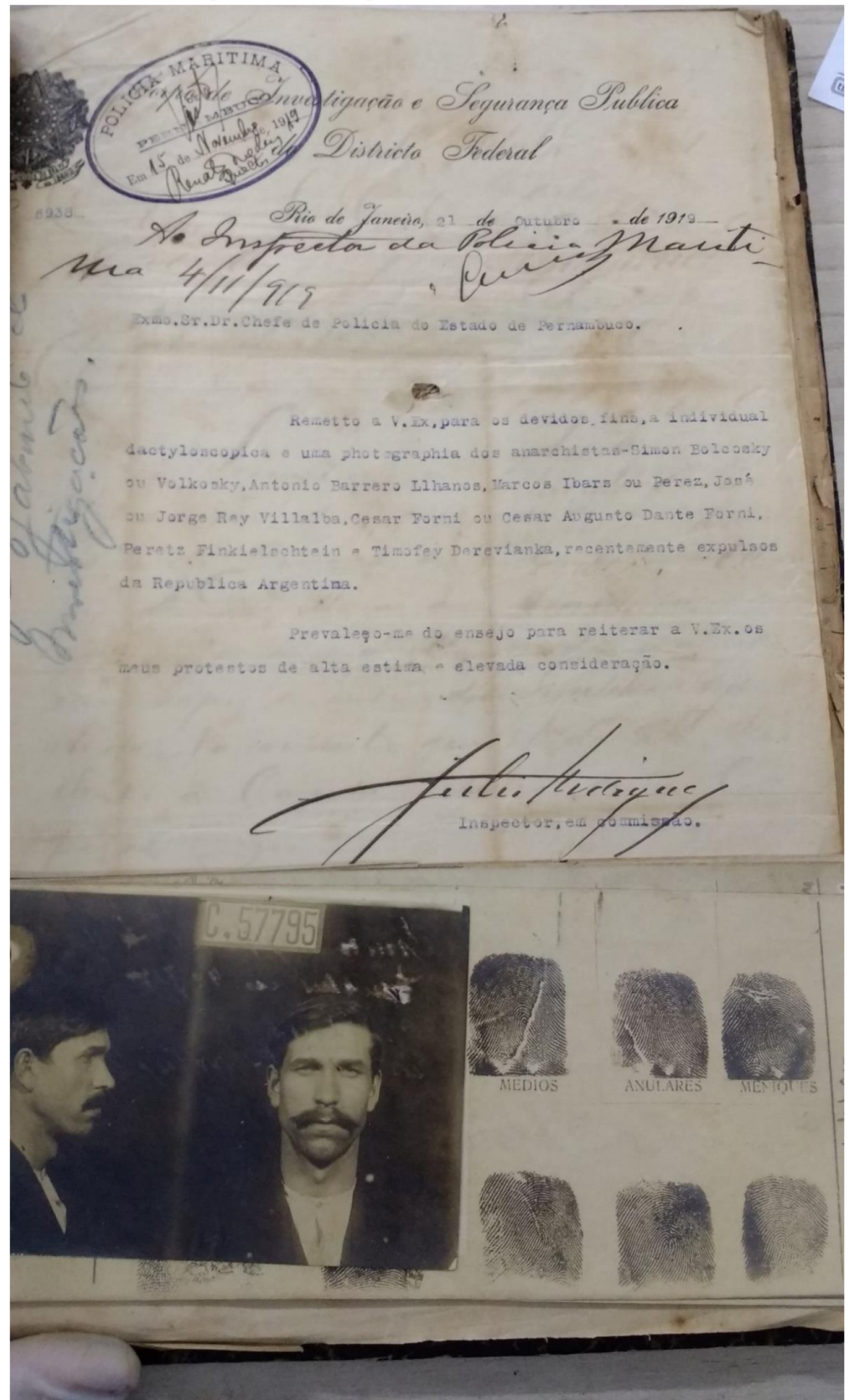


ANEXO 13 - As publicações em Ciências Penais da Revista Acadêmica da Faculdade de Direito do Recife - 1891 a 1930

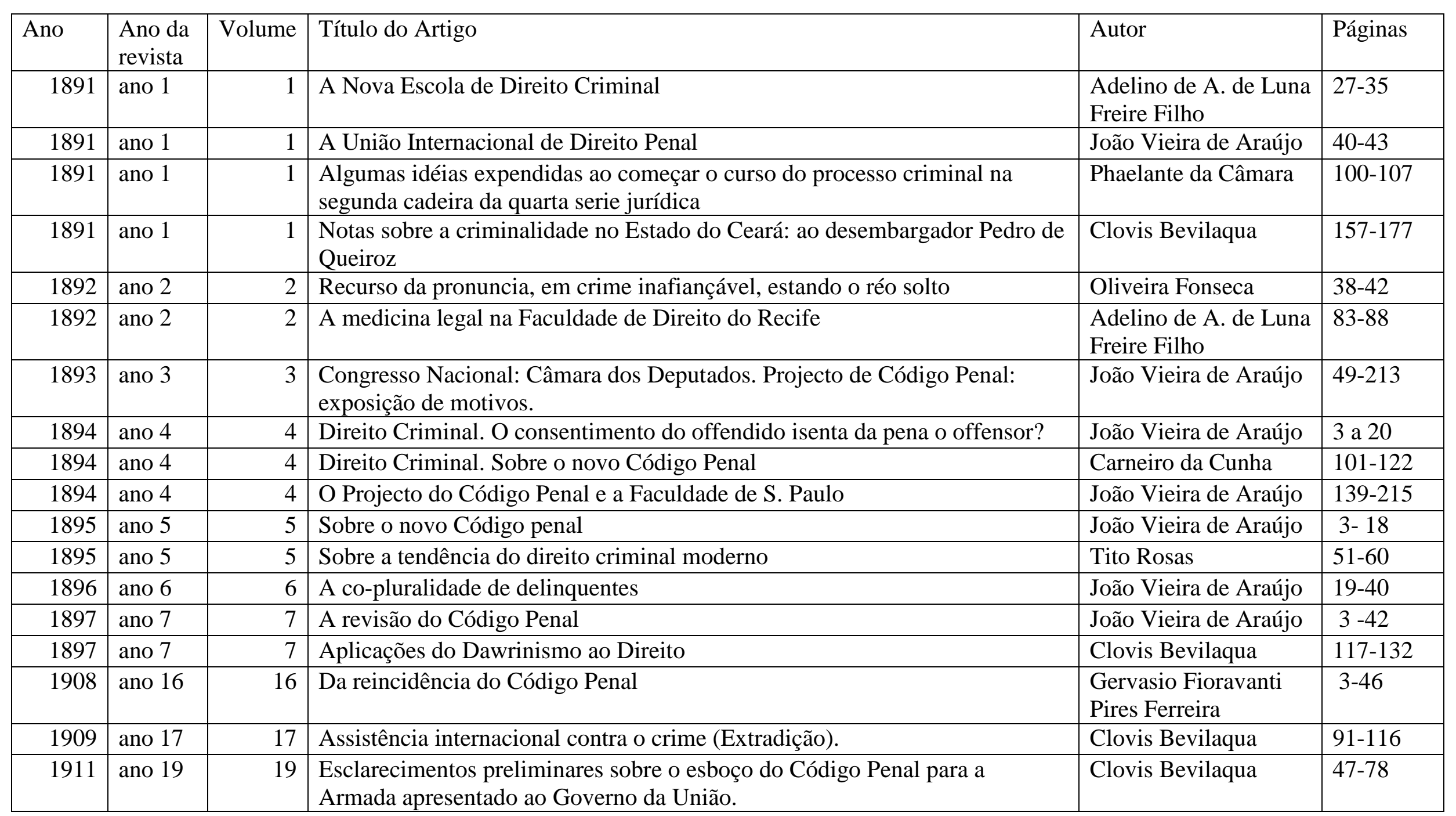




\begin{tabular}{|c|c|c|c|c|c|}
\hline 1914 & ano 22 & 22 & $\begin{array}{l}\text { A questão do crime, conceito e caracteres, de sua justificação, de suas } \\
\text { variações e de sua naturalidade, evolução e factores. }\end{array}$ & Laurindo Leão & $19-96$ \\
\hline 1921 & ano 29 & 29 & Influencia de clima e de moléstia no typo anthropologico brasileiro. & Lins e Silva & $205-213$ \\
\hline 1923 & ano 31 & 31 & O Código de Processo Criminal & Gennaro Guimarães & $71-98$ \\
\hline 1923 & ano 31 & 31 & Direito Processual. Lições de Theoria do Processo & Methodio Maranhão & $255-266$ \\
\hline 1926 & ano 34 & 34 & Da origem do habeas-corpus & Hersilio de Souza & $55-86$ \\
\hline 1929 & ano 37 & 37 & Homenagem a Enrico Ferri & Octavio Tavares & $11-24$ \\
\hline
\end{tabular}


